\title{
Open-Shell Fluorination of Alkyl Bromides: Unexpected Selectivity in a Silyl Radical-Mediated Chain Process
}

Gabrielle H. Lovett ${ }^{\dagger}$, Shuming Chen ${ }^{\ddagger}$, Xiao-Song Xue ${ }^{\ddagger}$, K. N. Houk ${ }^{*}$, and David W. C. MacMillan*广

'Merck Center for Catalysis at Princeton University, Princeton, New Jersey 08544, United States

Department of Chemistry and Biochemistry, University of California, Los Angeles, California, 90095, United States 


\section{Table of Contents}

1. General Experimental Protocols

2. Procedure for Optimization Studies

3. Optimization Table and Control Studies

4. Substrate Synthesis

5. General Procedure for Fluorination of Alkyl Bromides

S12

6. Characterization of Key Compounds

S13

7. Mechanistic Studies

S28

8. Computational Studies

S33

9. References

S78

10. Spectral Data

S81 


\section{General Experimental Protocols}

Commercial reagents were purified prior to use following the guidelines of Perrin and Armarego. ${ }^{1}$ Solvents were dried using a J. C. Meyer solvent purification system. All other commercial reagents and solvents were used as received. Organic solutions were concentrated under reduced pressure on a Büchi rotary evaporator using a water bath. Chromatographic purification of products was accomplished using forced-flow chromatography on silica gel (Fluka, 230-400 mesh) according to the method of Still ${ }^{2}$, or using preparative thin-layer chromatography (PTLC) with Uniplate 2000 micron silica gel plates. Visualization of the developed chromatogram was performed by fluorescence quenching or $\mathrm{KMnO}_{4}$ stain. ${ }^{1} \mathrm{H}$ NMR spectra were recorded on a Bruker UltraShield Plus Avance III $500 \mathrm{MHz}$ and are internally referenced to residual protic $\mathrm{CDCl}_{3}(\delta 7.26 \mathrm{ppm})$. Data for ${ }^{1} \mathrm{H}$ NMR are reported as follows: chemical shift $(\delta \mathrm{ppm})$, multiplicity ( $\mathrm{s}=$ singlet, $\mathrm{d}=$ doublet, $\mathrm{t}=$ triplet, $\mathrm{q}=$ quartet, $\mathrm{m}=$ multiplet, $\mathrm{dd}=$ doublet of doublets, $\mathrm{dt}=$ doublet of triplets, $\mathrm{br}=\mathrm{broad}$ ), coupling constant $(\mathrm{Hz})$, and integration. Non-first order multiplets are identified as "nfom". ${ }^{13} \mathrm{C}$ NMR spectra were recorded on a Bruker UltraShield Plus Avance III $500 \mathrm{MHz}(125 \mathrm{MHz})$ and data are reported in terms of chemical shift relative to $\mathrm{CDCl}_{3}(77.16 \mathrm{ppm}) .{ }^{19} \mathrm{~F}$ NMR spectra were recorded on a Bruker NanoBay $300 \mathrm{MHz}(282 \mathrm{MHz}$ ) and Bruker NanoBay $400 \mathrm{MHz}(376 \mathrm{MHz})$. IR spectra were recorded on a Perkin Elmer Spectrum 100 FTIR spectrometer and are reported in wavenumbers $\left(\mathrm{cm}^{-1}\right)$. High Resolution Mass Spectra were obtained from the Princeton University Mass Spectral Facility. 


\section{Procedure for Optimization Studies}

To an $8 \mathrm{~mL}$ vial equipped with a stir bar was added 1-benzoylpiperidine-4-bromide (26.8 mg, 0.1 mmol, 1.0 equiv.), $N$-Fluorobenzenesulfonimide (NFSI) (94.6 mg, $0.3 \mathrm{mmol}, 3$ equiv.), and $\mathrm{K}_{3} \mathrm{PO}_{4}$ (42.5 mg, $0.2 \mathrm{mmol}, 2$ equiv.). Benzophenone ( $0.5 \mathrm{~mL}$ of $5 \mu \mathrm{mol} / \mathrm{mL}$ in $\mathrm{MeCN}$ stock solution) was then added followed by addition of water $(0.5 \mathrm{~mL})$. (TMS $)_{3} \mathrm{Si}-\mathrm{OH}$ (Super silanol) ${ }^{3}(46.3 \mathrm{mg}$, 0.175 mmol, 1.75 equiv.) was then added and the reaction was capped, purged with nitrogen, and wrapped with parafilm. The reaction mixture was stirred and irradiated using $40 \mathrm{~W}$ blue LED lamps ( $5 \mathrm{~cm}$ away, with cooling fan to keep the reaction at room temperature) for 6 hours. The reaction was quenched by exposure to air. 4-Fluoroanisole (internal standard, $1.000 \mathrm{~mL}$ of a 0.1 $\mathrm{mmol} / \mathrm{mL}$ EtOAc stock solution) was added, and the reaction mixture was analyzed by ${ }^{19} \mathrm{~F}$ NMR. 


\section{Optimization Table and Control Studies}

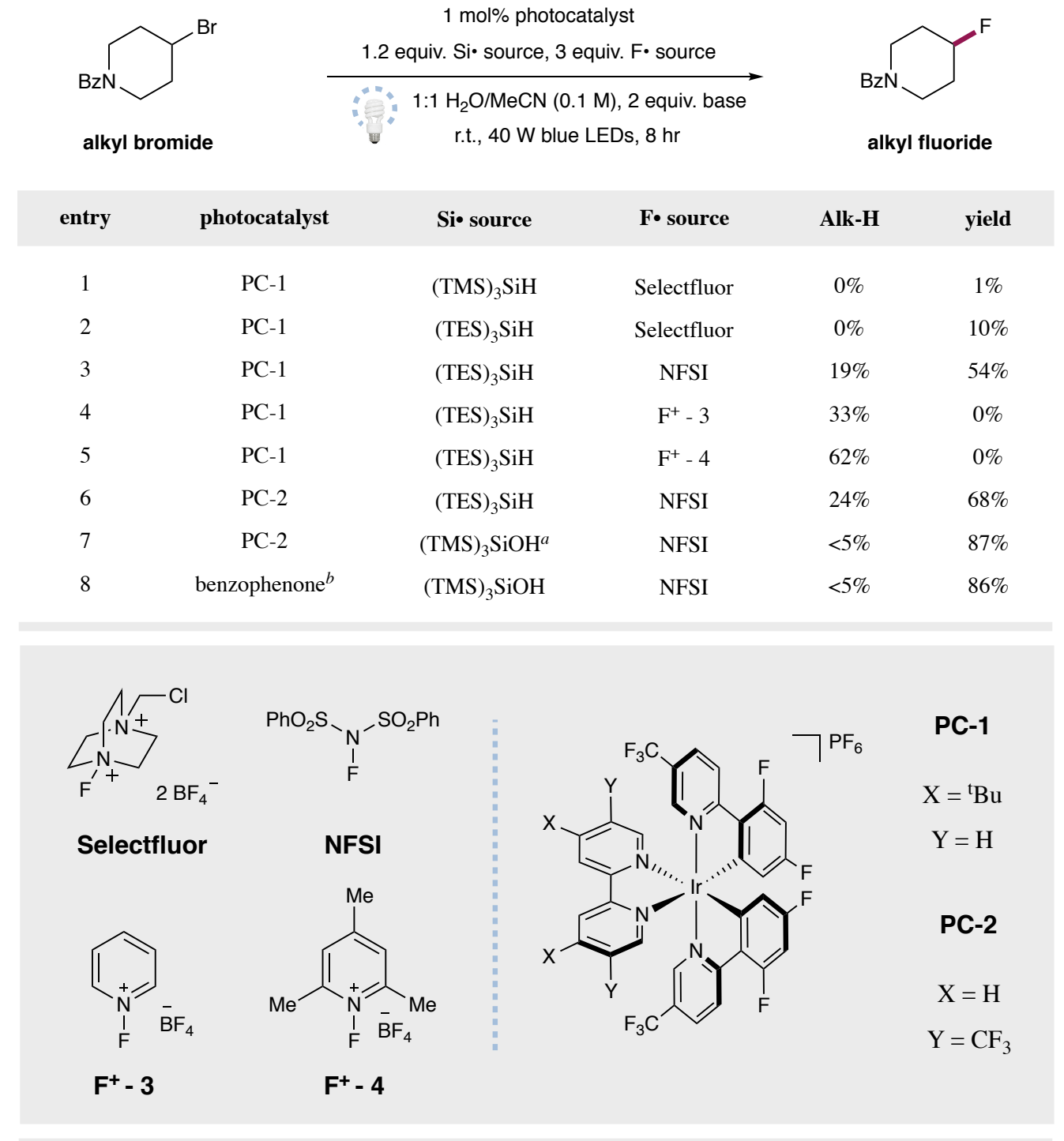

Yields determined by ${ }^{19} \mathrm{~F}$ NMR vs. internal standard. Base used is $\mathrm{Na}_{2} \mathrm{HPO}_{4}$ unless othersiwe specified. ${ }^{a}$ with 1.75 equiv. (TMS) ${ }_{3} \mathrm{SiOH}$ and using $\mathrm{K}_{3} \mathrm{PO}_{4}$ as base. ${ }^{b}$ with $2.5 \mathrm{~mol} \%$ benzophenone.

Figure S1: Optimization experiments. Reactions performed and analyzed as outlined in Section 2. 


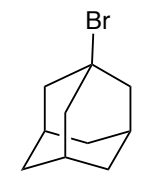

alkyl bromide

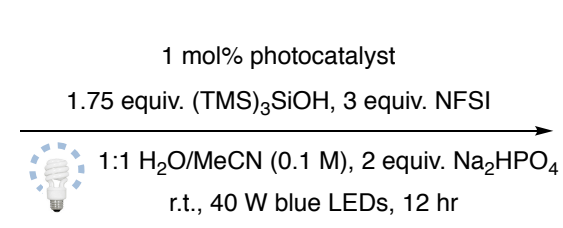

r.t., $40 \mathrm{~W}$ blue LEDs, $12 \mathrm{hr}$

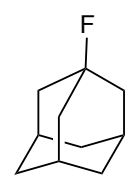

alkyl fluoride

\begin{tabular}{|c|c|c|}
\hline entry & conditions & yield \\
\hline 1 & {$\left[\operatorname{Ir}\left(\mathrm{dF}\left(\mathrm{CF}_{3}\right) \mathrm{ppy}\right)_{2}\left(5,5^{\prime}-\mathrm{dCF}_{3} \mathrm{bpy}\right)\right] \mathrm{PF}_{6}$} & $58 \%$ \\
\hline 2 & {$\left[\operatorname{Ir}\left(\mathrm{dF}\left(\mathrm{CF}_{3}\right) \mathrm{ppy}\right)_{2}(\mathrm{dtbbpy})\right] \mathrm{PF}_{6}$} & $48 \%$ \\
\hline 3 & {$\left[\operatorname{Ir}\left(\mathrm{dF}\left(\mathrm{CF}_{3}\right) \mathrm{ppy}\right)_{2}\left(4,4^{\prime}-\mathrm{dMebpy}\right)\right] \mathrm{PF}_{6}$} & $56 \%$ \\
\hline 4 & {$\left[\operatorname{Ir}\left(\mathrm{dF}\left(\mathrm{CF}_{3}\right) \mathrm{ppy}\right)_{2}(\mathrm{bpy})\right] \mathrm{PF}_{6}$} & $57 \%$ \\
\hline 5 & 9-Mesityl-10-methylacridinium perchlorate & $54 \%$ \\
\hline 6 & 4-CzIPN & $53 \%$ \\
\hline 7 & $\operatorname{Ir}(\text { ppy })_{3}$ & $40 \%$ \\
\hline 8 & $\operatorname{Ir}\left(5-\mathrm{CF}_{3}-4^{\prime}-\mathrm{OMe} \text { ppy }\right)_{3}$ & $43 \%$ \\
\hline 9 & fluorenone $^{a}$ & $52 \%$ \\
\hline 10 & benzophenone $^{a}$ & $58 \%$ \\
\hline
\end{tabular}

${ }^{a}$ Using $5 \mathrm{~mol} \%$ of each photosensitizer

Figure S2: Select examples from photocatalyst/catalyst screen. Reactions performed and analyzed as outlined in Section 2.

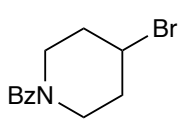

alkyl bromide

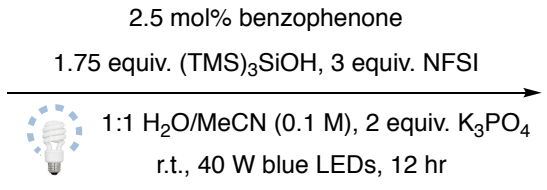

r.t., $40 \mathrm{~W}$ blue LEDs, $12 \mathrm{hr}$

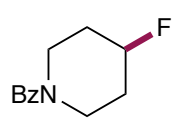

alkyl fluoride

\begin{tabular}{ccc|}
\hline entry & conditions & yield \\
\hline 1 & as shown & $86 \%$ \\
2 & no light & $0 \%$ \\
3 & no silanol & $0 \%$ \\
4 & no base & $62 \%$ \\
5 & no photocatalyst & $22 \%$ \\
6 & with AIBN, $80{ }^{\circ} \mathrm{C}^{a}$ & $0 \%$ \\
\hline
\end{tabular}

Yields determined by ${ }^{19} \mathrm{~F}$ NMR vs. internal standard. ${ }^{a}$ using $20 \mathrm{~mol} \%$ AIBN at $80{ }^{\circ} \mathrm{C}$ in the dark for 4 hrs.

Figure S3: Control experiments. Reactions performed and analyzed as outlined in Section 2. 


\section{Substrate Synthesis \\ (4-Bromopiperidin-1-yl)(phenyl)methanone}<smiles>[R5]N1CCC(Br)CC1</smiles>

Prepared from 4-Bromopiperidine hydrobromide via known literature procedure ${ }^{4}$. Data are consistent with those reported in the literature.

${ }^{1}$ H NMR (300 MHz, CDCl $) \delta 7.45-7.36(\mathrm{~m}, 5 \mathrm{H}), 4.44(\mathrm{p}, J=3.5 \mathrm{~Hz}, 1 \mathrm{H}), 4.11-3.18(\mathrm{~m}$, $4 \mathrm{H}), 2.39-1.85(\mathrm{~m}, 4 \mathrm{H})$

\section{(4-Bromopiperidin-1-yl)(6-(trifluoromethyl)pyridin-3-yl)methanone}<smiles>O=C(c1ccc(C(F)(F)F)nc1)N1CCC(Br)CC1</smiles>

Prepared from 4-Bromopiperidine hydrobromide via known literature procedure ${ }^{5}$. Data are consistent with those reported in the literature.

( \pm ) trans-5-(4-Bromotetrahydro-2H-pyran-2-yl)-2-(trifluoromethyl)pyridine<smiles>FC(F)(F)c1ccc(C2CC(Br)CCO2)cn1</smiles>

Prepared from 4-bromotetrahydropyran via known literature procedure ${ }^{6}$. Data are consistent with those reported in the literature.

${ }^{1}$ H NMR (400 MHz, CDCl $) \delta 8.69(\mathrm{~s}, 1 \mathrm{H}), 7.87(\mathrm{~d}, J=7.8 \mathrm{~Hz}, 1 \mathrm{H}), 7.67(\mathrm{~d}, J=8.2 \mathrm{~Hz}, 1 \mathrm{H})$, $5.04(\mathrm{~d}, J=10.9 \mathrm{~Hz}, 1 \mathrm{H}), 4.83-4.78(\mathrm{~m}, 1 \mathrm{H}), 4.17(\mathrm{td}, J=11.9,2.2 \mathrm{~Hz}, 1 \mathrm{H}), 4.07$ (dd, $J=12.0$, $5.1 \mathrm{~Hz}, 1 \mathrm{H}), 2.30-2.19(\mathrm{~m}, 2 \mathrm{H}), 2.10-1.96(\mathrm{~m}, 2 \mathrm{H})$. 


\section{cis- $N$-(3-Bromocyclobutyl)benzamide}<smiles>BrC1CC(N[Pb])C1</smiles>

Prepared from trans-3-hydroxycyclobutanamine hydrochloride via known literature procedure ${ }^{6}$. Data are consistent with those reported in the literature.

\section{3-Bromo-3-methylbutyl 4-chlorobenzoate}<smiles>CC(C)(Br)CCOC(=O)c1ccc(Cl)cc1</smiles>

Prepared via known literature procedure ${ }^{7}$. Data are consistent with those reported in the literature.

${ }^{1}$ H NMR (400 MHz, $\left.\mathbf{C D C l}_{3}\right) \delta 7.97(\mathrm{~d}, J=8.6 \mathrm{~Hz}, 2 \mathrm{H}), 7.42(\mathrm{~d}, J=8.6 \mathrm{~Hz}, 2 \mathrm{H}), 4.58(\mathrm{t}, J=6.7$ $\mathrm{Hz}, 2 \mathrm{H}), 2.30(\mathrm{t}, J=6.8 \mathrm{~Hz}, 2 \mathrm{H}), 1.85(\mathrm{~s}, 6 \mathrm{H})$.

\section{(3,3-Dibromobutyl)benzene}

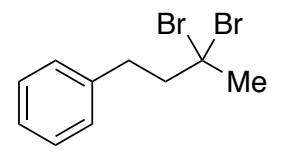

Prepared from 4-phenylbutan-2-one via known literature procedure ${ }^{8}$. Data are consistent with those reported in the literature.

${ }^{1}$ H NMR (400 MHz, CDCl $)$ ) $7.35-7.18(\mathrm{~m}, 5 \mathrm{H}), 3.08-3.01(\mathrm{~m}, 2 \mathrm{H}) 2.65-2.60(\mathrm{~m}, 2 \mathrm{H}), 2.59$ $(\mathrm{s}, 3 \mathrm{H})$. 


\section{(3-Bromo-3-methylpentyl)benzene}<smiles>CCC(C)(Br)CCc1ccccc1</smiles>

Prepared from the corresponding tertiary alcohol according to literature procedure for preparation of tertiary alkyl halides ${ }^{9}$. 3-Methyl-1-phenylpentan-3-ol (4.2 mL, 0.02 mol.) was added to a solution of $\mathrm{LiBr}(3.0 \mathrm{~g}, 0.03 \mathrm{~mol})$ in $48 \mathrm{wt} \%$ aqueous $\mathrm{HBr}$ at $0{ }^{\circ} \mathrm{C}$. The reaction mixture was allowed to warm to r.t., and it was stirred for 12 hours. The reaction was then diluted with $\mathrm{Et}_{2} \mathrm{O}$, washed with water, saturated $\mathrm{NaHCO}_{3}$, and brine, dried with $\mathrm{MgSO}_{4}$, and concentrated. The crude product was purified by distillation under reduced pressure to yield the pure product as a colorless oil (4.8 g, 90\% yield).

${ }^{1}$ H NMR (500 MHz, $\left.\mathbf{C D C l}_{3}\right) \delta 7.32-7.27(\mathrm{~m}, 2 \mathrm{H}), 7.24-7.18(\mathrm{~m}, 3 \mathrm{H}), 2.89-2.76(\mathrm{~m}, 2 \mathrm{H})$, $2.20-2.07(\mathrm{~m}, 2 \mathrm{H}), 2.03-1.85(\mathrm{~m}, 2 \mathrm{H}), 1.78(\mathrm{~s}, 3 \mathrm{H}), 1.08(\mathrm{t}, J=7.3 \mathrm{~Hz}, 3 \mathrm{H})$.

${ }^{13} \mathbf{C}$ NMR (126 MHz, $\left.\mathbf{C D C l}_{3}\right) \delta 141.85,128.62,128.57,126.11,73.90,47.15,38.40,32.51,31.08$, 10.43 .

IR (film) $v_{\max } 3027,2971,2937,1454$, and $1379 \mathrm{~cm}^{-1}$.

HRMS (GC-QTOF) m/z calcd. $\mathrm{C}_{12} \mathrm{H}_{16}{ }^{\circ+}\left([\mathrm{M}-\mathrm{HBr}]^{++}\right)$160.12465, found 160.12514 .

\section{3-Bromobutyl 4-hydroxybenzoate}<smiles>CC(Br)CCOC(=O)c1ccc(O)cc1</smiles>

To a solution of 4-hydroxybenzoic acid $(690 \mathrm{mg}, 5 \mathrm{mmol})$ and $\mathrm{K}_{2} \mathrm{CO}_{3}(1.4 \mathrm{~g}, 10 \mathrm{mmol})$ in $\mathrm{MeCN}$ $(0.3 \mathrm{M})$ was added 1,3-dibromobutane $(0.72 \mathrm{~mL}, 6 \mathrm{mmol})$. The reaction mixture was heated to 60 ${ }^{\circ} \mathrm{C}$ and stirred for 12 hours. The reaction was then diluted with EtOAc, washed with water and brine, dried with $\mathrm{MgSO}_{4}$, and concentrated. The crude product was purified by flash column chromatography to yield the pure product as a white solid (677 mg, 50\% yield). 
${ }^{1}$ H NMR (500 MHz, CDCl $) \delta 7.95(\mathrm{~d}, J=8.6 \mathrm{~Hz}, 2 \mathrm{H}), 6.95-6.76(\mathrm{~m}, 2 \mathrm{H}), 5.45$ (br s, 1H), 4.55 $-4.47(\mathrm{~m}, 1 \mathrm{H}), 4.45-4.25(\mathrm{~m}, 2 \mathrm{H}), 2.33-2.16(\mathrm{~m}, 2 \mathrm{H}), 1.79(\mathrm{~d}, J=6.7 \mathrm{~Hz}, 3 \mathrm{H})$.

${ }^{13}$ C NMR (126 MHz, $\left.\mathbf{C D C l}_{3}\right) \delta 166.34,159.96,132.11,122.80,115.38,62.99,47.15,40.01$, 26.70 .

IR (film) $v_{\max } 3338,2969,1682,1607,1591,1277,1165,1116,1101$, and $771 \mathrm{~cm}^{-1}$.

HRMS (GC-QTOF) m/z calcd. $\mathrm{C}_{11} \mathrm{H}_{13} \mathrm{BrO}_{3}{ }^{\cdot+}\left([\mathrm{M}]^{\bullet+}\right)$ 272.00426, found 272.0046.

\section{3-Bromo-3-methylbutyl 4-bromobenzoate}<smiles>CC(C)(Br)CCOC(=O)c1ccc(Br)cc1</smiles>

(3-Methylbut-2-en-1-yl)-4-bromobenzoate (1 g, $3.7 \mathrm{mmol}$ ) was dissolved in $33 \mathrm{wt}$ \% $\mathrm{HBr}$ in acetic acid at $0{ }^{\circ} \mathrm{C}$ and stirred at room temperature for 6 hours. The reaction mixture was diluted with DCM, washed with $\mathrm{NaHCO}_{3}$ and brine, and dried with $\mathrm{MgSO}_{4}$ and concentrated on rotary evaporator. The pure product was obtained as a white solid (351 mg, 27\% yield) after purification by flash column chromatography.

${ }^{1}$ H NMR (500 MHz, $\left.\mathbf{C D C l}_{3}\right) \delta 7.89(\mathrm{~d}, J=8.5 \mathrm{~Hz}, 2 \mathrm{H}), 7.58(\mathrm{~d}, J=8.6 \mathrm{~Hz}, 2 \mathrm{H}), 4.58(\mathrm{t}, J=6.7$ $\mathrm{Hz}, 2 \mathrm{H}), 2.30(\mathrm{t}, J=6.8 \mathrm{~Hz}, 2 \mathrm{H}), 1.85(\mathrm{~s}, 6 \mathrm{H})$.

${ }^{13}$ C NMR (126 MHz, CDCl $) \delta$ 165.76, 131.79, 131.11, 129.02, 128.19, 64.02, 63.39, 45.37, 34.75 .

IR (film) $v_{\max } 2969,1721,1591,1272,1115$, and $1103 \mathrm{~cm}^{-1}$.

HRMS (GC-QTOF) m/z calcd. for fragment $\mathrm{C}_{7} \mathrm{H}_{4} \mathrm{BrO}^{\cdot+}\left([\mathrm{M}]^{\bullet+}\right)$ 182.944, found 182.94459 .

\section{3-Bromo-3-methylbutyl 4-formylbenzoate}<smiles>CC(C)(Br)CCOC(=O)c1ccc(C=O)cc1</smiles> 
(3-Methylbut-2-en-1-yl)-4-formylbenzoate (1 g, $4.6 \mathrm{mmol}$ ) was dissolved in $33 \mathrm{wt} . \% \mathrm{HBr}$ in acetic acid at $0{ }^{\circ} \mathrm{C}$ and stirred at room temperature for 6 hours. The reaction mixture was diluted with DCM, washed with $\mathrm{NaHCO}_{3}$ and brine, and dried with $\mathrm{MgSO}_{4}$ and concentrated on rotary evaporator. The pure product was obtained as a white solid (329 mg, 24\% yield) after purification by flash column chromatography.

${ }^{1}$ H NMR (300 MHz, $\left.\mathbf{C D C l}_{3}\right) \delta 10.11(\mathrm{~s}, 1 \mathrm{H}), 8.20(\mathrm{~d}, J=8.3 \mathrm{~Hz}, 2 \mathrm{H}), 7.96(\mathrm{~d}, J=8.5 \mathrm{~Hz}, 2 \mathrm{H})$, $4.63(\mathrm{t}, J=6.8 \mathrm{~Hz}, 2 \mathrm{H}), 2.33(\mathrm{t}, J=6.8 \mathrm{~Hz}, 2 \mathrm{H}), 1.87(\mathrm{~s}, 6 \mathrm{H})$.

${ }^{13}$ C NMR (126 MHz, CDCl $) \delta 191.63,165.45,139.21,135.07,130.21,129.58,63.75,45.32$, 34.76 .

IR (film) $v_{\max } 2972,1722,1707,1275,1201,1112$, and $1016 \mathrm{~cm}^{-1}$.

HRMS (ESI-TOF) m/z calcd. for $\mathrm{C}_{13} \mathrm{H}_{16} \mathrm{BrO}_{3}{ }^{+}\left([\mathrm{M}+\mathrm{H}]^{+}\right)$299.02773, found 299.02847 .

2-(Acetoxymethyl)-5-(3-(3-bromobutyl)-2,4-dioxo-3,4-dihydropyrimidin-1(2H)yl)tetrahydrofuran-3,4-diyl diacetate<smiles>CC(=O)OCC1OC(n2ccc(=O)n(CCC(C)Br)c2=O)C(OC(C)=O)[C@@H]1OC(C)=O</smiles>

To a solution of tri-O-acetyluridine (926 mg, $2.5 \mathrm{mmol})$ and $\mathrm{K}_{2} \mathrm{CO}_{3}(515 \mathrm{mg}, 3.75 \mathrm{mmol})$ in DMF $(0.3 \mathrm{M})$ was added 1,3 -dibromobutane $(0.45 \mathrm{~mL}, 3.75 \mathrm{mmol})$. The reaction mixture was heated to $60{ }^{\circ} \mathrm{C}$ and stirred for 12 hours. The reaction was then diluted with EtOAc, washed with water and brine, dried with $\mathrm{MgSO}_{4}$ and concentrated on rotary evaporator. The crude product was purified by flash column chromatography to yield the pure product as a sticky solid (650 mg, 51\% yield).

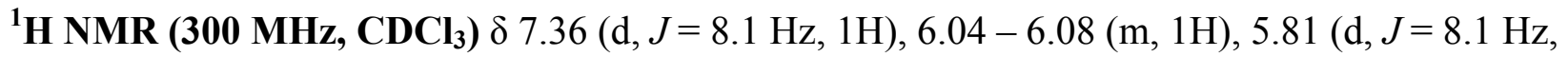
$1 \mathrm{H}), 5.37-5.31(\mathrm{~m}, 2 \mathrm{H}), 4.37-4.34(\mathrm{~m}, 3 \mathrm{H}), 4.20-4.10(\mathrm{~m}, 2 \mathrm{H}), 4.05-3.95(\mathrm{~m}, 1 \mathrm{H}), 2.33-$ $2.16(\mathrm{~m}, 11 \mathrm{H})$.

${ }^{13} \mathbf{C}$ NMR (126 MHz, $\mathbf{C D C l}_{3}$ ) (1:1 mixture of diastereomers) $\delta$ 170.27, 169.74, 162.21, 150.88, $137.37,137.34,102.94,88.74,88.66,79.85,79.83,73.13,70.12,70.09,63.07,63.04,47.94,47.92$, $40.12,38.51,38.48,26.64,20.95,20.64$.

IR (film) $v_{\max } 1748,1712,1669,1457,1373,1224,1097$, and $1049 \mathrm{~cm}^{-1}$.

HRMS (ESI-TOF) m/z calcd. for $\mathrm{C}_{19} \mathrm{H}_{26} \mathrm{BrN}_{2} \mathrm{O}_{9}{ }^{+}\left([\mathrm{M}+\mathrm{H}]^{+}\right)$505.08162, found 505.0803. 


\section{General Procedure for Fluorination of Alkyl Bromides}

To an $8 \mathrm{~mL}$ vial equipped with a stir bar was added benzophenone $(2.3 \mathrm{mg}, 12.5 \mu \mathrm{mol}, 0.025$ equiv.), alkyl bromide (0.5 mmol, 1.0 equiv.), NFSI (473 mg, $1.5 \mathrm{mmol}, 3$ equiv.), and $\mathrm{K}_{3} \mathrm{PO}_{4}(212$ mg, 1.0 mmol, 2 equiv.). Solvents $\mathrm{MeCN}$ and $\mathrm{H}_{2} \mathrm{O}$ were added (2.5 mL of each, sequentially) followed by super silanol (231.5 mg, $0.875 \mathrm{mmol}, 1.75$ equiv.). The vial was capped, purged with nitrogen, and wrapped with parafilm. The biphasic, heterogeneous reaction was vigorously stirred and irradiated using $40 \mathrm{~W}$ blue LED lamps ( $5 \mathrm{~cm}$ away, with cooling fan to keep the reaction at room temperature) for 6 hours. The reaction was quenched by exposure to air. 4-fluoroanisole (internal standard, $1.000 \mathrm{~mL}$ of a $0.5 \mathrm{mmol} / \mathrm{mL}$ EtOAc stock solution) and brine were added to the reaction mixture to collect ${ }^{19} \mathrm{~F}$ NMR yields. The reaction mixture was then further partitioned between EtOAc and brine. The organic phase was dried with anhydrous $\mathrm{MgSO}_{4}$, filtered, and carefully concentrated. The residue was purified by flash column chromatography or preparative TLC with hexane/EtOAc or pentane/Et ${ }_{2} \mathrm{O}$ mixture as the eluent.

Note: For each reaction, conditions may vary slightly in benzophenone loading and use of $\mathrm{Na}_{2} \mathrm{HPO}_{4} \bullet 7 \mathrm{H}_{2} \mathrm{O}$ as inorganic base. See examples below for detail. When possible, $\mathrm{Et}_{2} \mathrm{O}$ was used during workup in place of EtOAc. All reported isolated yields are $>95 \%$ purity. Purification by reverse-phase chromatography or preparative TLC was used to remove any residual silane byproducts still present. 


\section{Characterization for All Key Compounds}

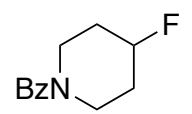

\section{(4-Fluoropiperidin-1-yl)(phenyl)methanone (8)}

Prepared following the general procedure using benzophenone (2.5 mol\%), NFSI (3 equiv.), $\mathrm{K}_{3} \mathrm{PO}_{4}$ (2 equiv.), (TMS) ${ }_{3} \mathrm{SiOH}$ (1.75 equiv.), (4-bromopiperidin-1-yl)(phenyl)methanone (134 mg, $0.5 \mathrm{mmol}, 1$ equiv.), and $\mathrm{MeCN} / \mathrm{H}_{2} \mathrm{O}(1: 1,5 \mathrm{~mL})$ under blue LED irradiation for 2 hours. The product was obtained as a white solid ( $87 \mathrm{mg}, 84 \%$ yield) after purification by flash column chromatography. The NMR data are consistent with those reported in the literature ${ }^{4}$.

${ }^{1}$ H NMR (300 MHz, CDCl $) \delta 7.46-7.35(\mathrm{~m}, 5 \mathrm{H}), 5.02-4.78(\mathrm{~m}, 1 \mathrm{H}), 4.17-3.26(\mathrm{~m}, 4 \mathrm{H})$, $1.77(\mathrm{~d}, J=60.8 \mathrm{~Hz}, 4 \mathrm{H})$.

${ }^{13}$ C NMR (126 MHz, CDCl $) \delta 170.61,135.96,129.86,128.67,126.94,87.80$ (d, $\left.J=171.5 \mathrm{~Hz}\right)$, $43.69,38.17$.

${ }^{19}$ F NMR (282 MHz, $\left.\mathrm{CDCl}_{3}\right) \delta-183.16(\mathrm{~m})$.

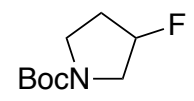

tert-Butyl 3-fluoropyrrolidine-1-carboxylate (12)

Prepared following the general procedure using benzophenone (2.5 mol\%), NFSI (3 equiv.), $\mathrm{K}_{3} \mathrm{PO}_{4}$ (2 equiv.), (TMS) ${ }_{3} \mathrm{SiOH}$ (1.75 equiv.), tert-Butyl 3-bromopyrrolidine-1-carboxylate (125 mg, $0.5 \mathrm{mmol}, 1$ equiv.), and $\mathrm{MeCN} / \mathrm{H}_{2} \mathrm{O}(1: 1,5 \mathrm{~mL})$ under blue LED irradiation for 4 hours. The product was obtained as a colorless oil (71 $\mathrm{mg}, 75 \%$ yield) after purification by flash column chromatography. The NMR data are consistent with those reported in the literature ${ }^{10}$.

${ }^{1}$ H NMR (500 MHz, CDCl $) \delta 5.20(\mathrm{~m}, 1 \mathrm{H}), 3.76-3.38(\mathrm{~m}, 4 \mathrm{H}), 2.27-1.85(\mathrm{~m}, 2 \mathrm{H}), 1.46(\mathrm{~s}$, 9H).

${ }^{13}$ C NMR (126 MHz, $\mathbf{C D C l}_{3}$ ) (rotomeric mixture), $\delta$ 154.60, 154.48, 93.49 (d, $J=102.6 \mathrm{~Hz}$ ), $92.10(\mathrm{~d}, J=102.6 \mathrm{~Hz}), 79.69,52.83$ (d, $J=23.4 \mathrm{~Hz}), 52.48$ (d, $J=23.0 \mathrm{~Hz}), 43.86,43.49,32.63$ $(\mathrm{d}, J=21.7 \mathrm{~Hz}), 31.89(\mathrm{~d}, J=21.7 \mathrm{~Hz}), 28.61$. 
${ }^{19}$ F NMR (282 MHz, $\left.\mathbf{C D C l}_{3}\right) \delta-172.89--179.99(\mathrm{~m})$.

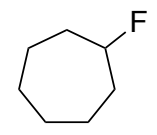

\section{Fluorocycloheptane (14)}

Prepared following the general procedure using benzophenone (2.5 mol\%), NFSI (3 equiv.), $\mathrm{K}_{3} \mathrm{PO}_{4}$ (2 equiv.), (TMS) $)_{3} \mathrm{SiOH}$ (1.75 equiv.), bromocycloheptane (88.5 mg, $0.5 \mathrm{mmol}, 1$ equiv.), and $\mathrm{MeCN} / \mathrm{H}_{2} \mathrm{O}(1: 1,5 \mathrm{~mL})$ under blue LED irradiation for 1 hour. Pure product could not be obtained due to product volatility. As such ${ }^{19} \mathrm{~F}$ NMR and crude ${ }^{1} \mathrm{H}$ NMR are provided. The NMR data are consistent with those reported in the literature ${ }^{11}$. $\left(99 \%{ }^{19} \mathrm{~F}\right.$ NMR yield against internal standard)

${ }^{1}$ H NMR (500 MHz, CDCl $) \delta 4.73(\mathrm{dtt}, J=47.5,8.0,4.4 \mathrm{~Hz}, 1 \mathrm{H}), 2.02-1.75(\mathrm{~m}, 4 \mathrm{H}), 1.62-$ $1.48(\mathrm{~m}, 4 \mathrm{H}), 1.34-1.20(\mathrm{~m}, 4 \mathrm{H})$.

${ }^{19}$ F NMR (282 MHz, CDCl 3$) \delta-163.89(\mathrm{~m})$.

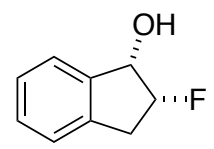

\section{cis-2-fluoro-2,3-dihydro-1H-inden-1-ol (15)}

Prepared following the general procedure using benzophenone (5 mol\%), NFSI (3 equiv.), $\mathrm{Na}_{2} \mathrm{HPO}_{4} \bullet 7 \mathrm{H}_{2} \mathrm{O}$ (2 equiv.), (TMS) ${ }_{3} \mathrm{SiOH}$ (1.75 equiv.), trans-2-bromo-2,3-dihydro- $1 H$-inden-1-ol (107 mg, $0.5 \mathrm{mmol}, 1$ equiv.), and $\mathrm{MeCN} / \mathrm{H}_{2} \mathrm{O}$ (1:1, $5 \mathrm{~mL}$ ) under blue LED irradiation for 4 hours. The product was obtained as a white solid (47 mg, 62\% yield, 3.8:1 d.r.) after purification by flash column chromatography. The NMR data obtained match those reported in the literature for both the major and minor diastereomers ${ }^{12}$.

${ }^{19}$ F NMR (376 MHz, $\mathbf{C D C l}_{3}$ ) (3.8:1 mixture of diastereomers) $\delta-85.59$ (dddd, $J=52.0,22.6$, 17.6, 15.7 Hz, 1F, major), -201.50 (m, 1F, minor)

${ }^{1} \mathbf{H}$ NMR (500 MHz, $\mathbf{C D C l}_{3}$ ) (3.8:1 mixture of diastereomers) minor diastereomer in brackets [ ]: $\delta[7.50-7.46,0.26 \mathrm{H})], 7.43-7.40(\mathrm{~m}, 1 \mathrm{H}), 7.35-7.27(\mathrm{~m}, 2 \mathrm{H})$ [overlapping $0.26 \mathrm{H}], 7.27-7.22$ 
$(\mathrm{m}, 1 \mathrm{H})$ [overlapping $0.53 \mathrm{H}$ ], $5.38-5.08(\mathrm{~m}, 2 \mathrm{H})$ [overlapping $0.53 \mathrm{H}$ ], $3.40(\mathrm{td}, J=16.0,6.7 \mathrm{~Hz}$, $1 \mathrm{H}),[3.28-3.08(\mathrm{~m}, 0.53 \mathrm{H})$, overlapping] $3.12-3.00(\mathrm{~m}, 1 \mathrm{H}),[2.37(\mathrm{dd}, J=10.4,4.4 \mathrm{~Hz}$, $0.26 \mathrm{H})], 2.06(\mathrm{~d}, J=5.5 \mathrm{~Hz}, 1 \mathrm{H})$.

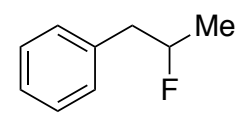

\section{(2-Fluoropropyl)benzene (17)}

Prepared following the general procedure using benzophenone (2.5 mol\%), NFSI (3 equiv.), $\mathrm{K}_{3} \mathrm{PO}_{4}$ (2 equiv.), (TMS) $)_{3} \mathrm{SiOH}$ (1.75 equiv.), (2-bromopropyl)benzene (100 mg, $0.5 \mathrm{mmol}, 1$ equiv.), and $\mathrm{MeCN} / \mathrm{H}_{2} \mathrm{O}(1: 1,5 \mathrm{~mL})$ under blue LED irradiation for 4 hours. The pure product was obtained as a colorless oil ( $38 \mathrm{mg}, 56 \%$ yield) after purification by flash column chromatography. The NMR data are consistent with those reported in the literature ${ }^{13} .\left(72 \%{ }^{19} \mathrm{~F}\right.$ NMR yield against internal standard)

${ }^{1}$ H NMR (500 MHz, CDCl$) \delta 7.31(\mathrm{~m}, 2 \mathrm{H}), 7.23(\mathrm{~m}, 3 \mathrm{H}), 4.95$ - $4.78(\mathrm{~m}, 1 \mathrm{H}), 3.05$ - $2.79(\mathrm{~m}$, $2 \mathrm{H}), 1.35(\mathrm{dd}, \mathrm{J}=23.7,6.1 \mathrm{~Hz}, 3 \mathrm{H})$.

${ }^{13}$ C NMR (126 MHz, CDCl $) \delta 137.36(\mathrm{~d}, J=5.5 \mathrm{~Hz}), 129.54,128.57,126.71,91.28(\mathrm{~d}, J=168.1$ $\mathrm{Hz}), 43.44$ (d, $J=21.5 \mathrm{~Hz}), 20.73(\mathrm{~d}, J=22.6 \mathrm{~Hz})$.

${ }^{19}$ F NMR (282 MHz, $\left.\mathbf{C D C l}_{3}\right) \delta-170.72(\mathrm{~m})$.

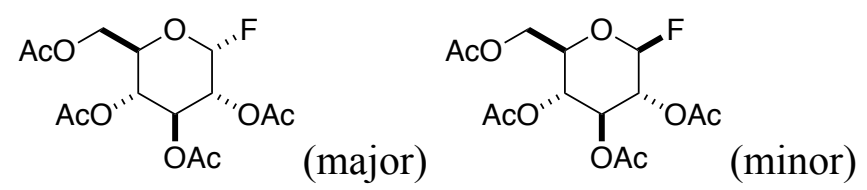

\section{2-(Acetoxymethyl)-6-fluorotetrahydro-2H-pyran-3,4,5-triyl triacetate (19)}

Prepared following the general procedure using benzophenone (2.5 mol\%), NFSI (3 equiv.), $\mathrm{Na}_{2} \mathrm{HPO}_{4} \cdot 7 \mathrm{H}_{2} \mathrm{O}$ (2 equiv.), (TMS) ${ }_{3} \mathrm{SiOH}$ (1.75 equiv.), 2-(Acetoxymethyl)-6-bromotetrahydro2H-pyran-3,4,5-triyl triacetate (175 mg, $0.5 \mathrm{mmol}, 1$ equiv.), and $\mathrm{MeCN} / \mathrm{H}_{2} \mathrm{O}(1: 1,5 \mathrm{~mL})$ under blue LED irradiation for 2 hours. The product was obtained as a white solid (151 mg, 86\% yield, 5:1 d.r.) after purification by flash column chromatography. The NMR data obtained match those 
reported in the literature for both the major and minor diastereomers ${ }^{14}$. (Note: $92 \%$ yield, 4:1 d.r. ${ }^{19} \mathrm{~F}$ NMR yield and d.r. against internal standard)

*Note: the control experiment without (TMS) $)_{3} \mathrm{SiOH}$ gave $0 \%$ yield in 2 hours.

${ }^{19} \mathbf{F}$ NMR (282 MHz, CDCl $)$ (5:1 mixture of diastereomers) $\delta-137.09$ (dd, $J=52.0,10.3 \mathrm{~Hz}, 1 \mathrm{~F}$, minor), -149.73 (dd, $J=52.9,24.3 \mathrm{~Hz}, 5 \mathrm{~F}$, major)

${ }^{1} \mathbf{H}$ NMR (500 MHz, $\mathbf{C D C l}_{3}$ ) minor diastereomer in brackets [ ]: $\delta 5.75(\mathrm{dd}, J=52.8,2.8 \mathrm{~Hz}, 1 \mathrm{H})$, $5.49(\mathrm{t}, J=9.9 \mathrm{~Hz}, 1 \mathrm{H}),[5.35(\mathrm{dd}, J=52.0,6.1 \mathrm{~Hz}, 0.2 \mathrm{H})],[5.22-5.18(\mathrm{~m}, 0.4 \mathrm{H})], 5.15(\mathrm{t}, J=$ $9.9 \mathrm{~Hz}, 1 \mathrm{H}),[5.08(\mathrm{~m}, 0.2 \mathrm{H})], 4.95(\mathrm{ddd}, J=24.2,10.2,2.8 \mathrm{~Hz}, 1 \mathrm{H}), 4.28(\mathrm{dd}, J=12.4,4.0 \mathrm{~Hz}$, $1 \mathrm{H}),[4.23(\mathrm{dd}, J=13.0,3.7 \mathrm{~Hz}, 0.4 \mathrm{H})], 4.22-4.09(\mathrm{~m}, 2 \mathrm{H}),[3.89(\mathrm{~m}, 0.2 \mathrm{H})], 2.10(\mathrm{~m}, 6 \mathrm{H})$ [overlapping $1.2 \mathrm{H}$ ], $2.04(\mathrm{~s}, 3 \mathrm{H})$ [overlapping $0.6 \mathrm{H}$ ], $2.02(\mathrm{~s}, 3 \mathrm{H})$ [overlapping $0.6 \mathrm{H}$ ].

${ }^{1}$ H NMR (500 MHz, CDCl $)$ (major diastereomer) $\delta 5.75(\mathrm{dd}, J=52.8,2.8 \mathrm{~Hz}, 1 \mathrm{H}), 5.49(\mathrm{t}, J=$ $9.9 \mathrm{~Hz}, 1 \mathrm{H}), 5.15(\mathrm{t}, J=9.9 \mathrm{~Hz}, 1 \mathrm{H}), 4.95(\mathrm{ddd}, J=24.2,10.2,2.8 \mathrm{~Hz}, 1 \mathrm{H}), 4.28$ (dd, $J=12.4,4.0$ $\mathrm{Hz}, 1 \mathrm{H}), 4.22-4.09(\mathrm{~m}, 2 \mathrm{H}), 2.10(\mathrm{~m}, 6 \mathrm{H}), 2.04(\mathrm{~s}, 3 \mathrm{H}), 2.02(\mathrm{~s}, 3 \mathrm{H})$.

${ }^{13}$ C NMR (126 MHz, $\mathbf{C D C l}_{3}$ ) (major diastereomer) $\delta 170.71,170.14,170.10,169.58,103.86$ (d, $J=229.5 \mathrm{~Hz}), 70.31$ (d, $J=24.5 \mathrm{~Hz}), 69.88$ (d, $J=4.2 \mathrm{~Hz}), 69.49,67.42,61.30,20.83,20.76$, 20.69 .

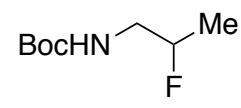

\section{tert-Butyl (2-fluoropropyl)carbamate (18)}

Prepared following the general procedure using benzophenone (5 mol\%), NFSI (3 equiv.), $\mathrm{Na}_{2} \mathrm{HPO}_{4} \cdot 7 \mathrm{H}_{2} \mathrm{O}$ (2 equiv.), (TMS) ${ }_{3} \mathrm{SiOH}$ (1.75 equiv.), tert-Butyl (2-bromopropyl)carbamate (119 $\mathrm{mg}, 0.5 \mathrm{mmol}, 1$ equiv.), and $\mathrm{MeCN} / \mathrm{H}_{2} \mathrm{O}(1: 1,5 \mathrm{~mL})$ under blue LED irradiation for 4 hours. The product was obtained as a colorless oil ( $73 \mathrm{mg}, 83 \%$ yield) after purification by flash column chromatography. The NMR data are consistent with those reported in the literature ${ }^{15}$.

${ }^{1}$ H NMR (500 MHz, CDCl $) \delta 4.87(\mathrm{br} \mathrm{s}, 1 \mathrm{H}), 4.72(\mathrm{~m}, 1 \mathrm{H}), 3.52-3.37(\mathrm{~m}, 1 \mathrm{H}), 3.14(\mathrm{~m}, 1 \mathrm{H})$, $1.45(\mathrm{~s}, 9 \mathrm{H}), 1.31$ (dd, $J=23.8,6.3 \mathrm{~Hz}, 3 \mathrm{H})$.

${ }^{13}$ C NMR (126 MHz, CDCl $) \delta 156.08,90.18(\mathrm{~d}, J=166.1 \mathrm{~Hz}), 79.73,45.91(\mathrm{~d}, J=20.4 \mathrm{~Hz})$, $28.49,18.21(\mathrm{~d}, J=22.0 \mathrm{~Hz})$.

${ }^{19}$ F NMR (282 MHz, $\left.\mathbf{C D C l}_{3}\right) \delta-179.83(\mathrm{~m})$. 


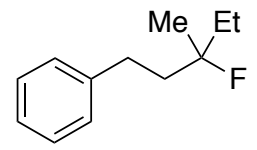

\section{(3-fluoro-3-methylpentyl)benzene (24)}

Prepared following the general procedure using benzophenone (2.5 mol\%), NFSI (3 equiv.), $\mathrm{K}_{3} \mathrm{PO}_{4}$ (2 equiv.), (TMS) ${ }_{3} \mathrm{SiOH}$ (1.75 equiv.), (3-bromo-3-methylpentyl)benzene (121 mg, 0.5 mmol, 1 equiv.), and $\mathrm{MeCN} / \mathrm{H}_{2} \mathrm{O}(1: 1,5 \mathrm{~mL})$ under blue LED irradiation for 1 hours. The product was obtained as a colorless oil (78 $\mathrm{mg}, 86 \%$ yield) after purification by flash column chromatography. The NMR data are consistent with those reported in the literature ${ }^{16}$.

${ }^{1}$ H NMR (500 MHz, CDCl $) \delta 7.30(\mathrm{~m}, 2 \mathrm{H}), 7.23-7.18(\mathrm{~m}, 3 \mathrm{H}), 2.74-2.69(\mathrm{~m}, 2 \mathrm{H}), 2.00-$ $1.82(\mathrm{~m}, 2 \mathrm{H}), 1.79-1.64(\mathrm{~m}, 2 \mathrm{H}), 1.37(\mathrm{~d}, J=21.8 \mathrm{~Hz}, 3 \mathrm{H}), 0.97$ (t, $J=7.5 \mathrm{~Hz}, 3 \mathrm{H})$.

${ }^{13}$ C NMR (126 MHz, $\left.\mathbf{C D C l}_{3}\right) \delta$ 142.30, 128.57, 128.44, 125.99, $97.53(\mathrm{~d}, J=167.7 \mathrm{~Hz}), 41.22$ $(\mathrm{d}, J=23.0 \mathrm{~Hz}), 32.43(\mathrm{~d}, J=23.6 \mathrm{~Hz}), 30.08(\mathrm{~d}, J=5.5 \mathrm{~Hz}), 23.85(\mathrm{~d}, J=25.0 \mathrm{~Hz}), 8.19(\mathrm{~d}, J=$ $7.1 \mathrm{~Hz})$.

${ }^{19}$ F NMR (470 MHz, CDCl$\left._{3}\right) \delta-146.65(\mathrm{~m})$.<smiles>CC(C)(F)CCOC(=O)c1ccc(Cl)cc1</smiles>

\section{3-Fluoro-3-methylbutyl 4-chlorobenzoate (25)}

Prepared following the general procedure using benzophenone (2.5 mol\%), NFSI (3 equiv.), $\mathrm{Na}_{2} \mathrm{HPO}_{4} \cdot 7 \mathrm{H}_{2} \mathrm{O}$ (2 equiv.), (TMS) ${ }_{3} \mathrm{SiOH}$ (1.75 equiv.), 3-bromo-3-methylbutyl 4-chlorobenzoate (153 mg, $0.5 \mathrm{mmol}, 1$ equiv.), and $\mathrm{MeCN} / \mathrm{H}_{2} \mathrm{O}(1: 1,5 \mathrm{~mL})$ under blue LED irradiation for 1 hour. The product was obtained as a white solid (149 $\mathrm{mg}, 82 \%$ yield) after purification by flash column chromatography. The NMR data are consistent with those reported in the literature ${ }^{17}$.

*Note: the control experiment without $(\mathrm{TMS})_{3} \mathrm{SiOH}$ gave $0 \%$ yield in 1 hour.

${ }^{1}$ H NMR (500 MHz, $\left.\mathbf{C D C l}_{3}\right) \delta 7.99-7.93(\mathrm{~m}, 2 \mathrm{H}), 7.41(\mathrm{~m}, 2 \mathrm{H}), 4.47(\mathrm{t}, J=6.8,2 \mathrm{H}), 2.11(\mathrm{dt}$, $J=19.6,6.8 \mathrm{~Hz}, 2 \mathrm{H}), 1.44(\mathrm{~d}, J=21.4,6 \mathrm{H})$.

${ }^{13}$ C NMR (126 MHz, $\left.\mathbf{C D C l}_{3}\right) \delta 165.81,139.58,131.08,128.90,128.77,94.36(\mathrm{~d}, J=166.2 \mathrm{~Hz})$, $61.32(\mathrm{~d}, J=6.0 \mathrm{~Hz}), 39.90(\mathrm{~d}, J=23.1 \mathrm{~Hz}), 27.22(\mathrm{~d}, J=24.6 \mathrm{~Hz})$. 
${ }^{19}$ F NMR (282 MHz, $\left.\mathrm{CDCl}_{3}\right) \delta-138.43(\mathrm{~m})$.

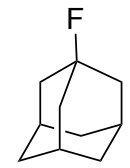

\section{1-Fluoroadamantane (22)}

Prepared following the general procedure using benzophenone (5 mol\%), NFSI (3 equiv.), $\mathrm{Na}_{2} \mathrm{HPO}_{4} \cdot 7 \mathrm{H}_{2} \mathrm{O}$ (0.5 equiv.), (TMS) $)_{3} \mathrm{SiOH}$ (1.75 equiv.), 1-bromoadamantane (108 mg, $0.5 \mathrm{mmol}$, 1 equiv.), and $\mathrm{MeCN} / \mathrm{H}_{2} \mathrm{O}(1: 1,5 \mathrm{~mL})$ under blue LED irradiation for 4 hours. The pure product was obtained as a white solid (38 $\mathrm{mg}, 49 \%$ yield) after purification by flash column chromatography. Pure product could not be obtained due to difficulty in separation from reaction byproducts. As such ${ }^{19}$ F NMR yield was obtained. The NMR data are consistent with those reported in the literature ${ }^{18} .\left(60 \%{ }^{19} \mathrm{~F}\right.$ NMR yield against internal standard $)$

${ }^{1}$ H NMR (500 MHz, CDCl $)$ ) $2.26-2.20(\mathrm{~m}, 3 \mathrm{H}), 1.89(\mathrm{~m}, 6 \mathrm{H}), 1.67-1.58(\mathrm{~m}, 6 \mathrm{H})$. ${ }^{13}$ C NMR (126 MHz, CDCl $) \delta 92.74(\mathrm{~d}, J=183.3 \mathrm{~Hz}), 42.89(\mathrm{~d}, J=17.0 \mathrm{~Hz}), 36.00$ (d, $J=2.0$ $\mathrm{Hz}), 31.62(\mathrm{~d}, J=9.7 \mathrm{~Hz})$.

${ }^{19}$ F NMR (282 MHz, $\left.\mathbf{C D C l}_{3}\right) \delta-128.48(\mathrm{~m})$

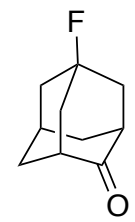

\section{5-Fluoroadamantan-2-one (23)}

Prepared following the general procedure using benzophenone (5 mol\%), NFSI (3 equiv.), $\mathrm{Na}_{2} \mathrm{HPO}_{4} \cdot 7 \mathrm{H}_{2} \mathrm{O}$ (0.5 equiv.), (TMS) ${ }_{3} \mathrm{SiOH}$ (1.75 equiv.), 5-bromoadaman-2-one (115 mg, 0.5 mmol, 1 equiv.), and $\mathrm{MeCN} / \mathrm{H}_{2} \mathrm{O}(1: 1,5 \mathrm{~mL})$ under blue LED irradiation for 4 hours. The pure product was obtained as a white solid (44 mg, 52\% yield) after purification by flash column chromatography. The NMR data are consistent with those reported in the literature ${ }^{19}$.

${ }^{1}$ H NMR (500 MHz, CDCl$) \delta 2.68(\mathrm{~s}, 2 \mathrm{H}), 2.43(\mathrm{~m}, 1 \mathrm{H}), 2.27$ - $2.20(\mathrm{~m}, 2 \mathrm{H}), 2.17$ - $2.07(\mathrm{~m}$, $4 \mathrm{H}), 2.02-1.90(\mathrm{~m}, 4 \mathrm{H})$. 
${ }^{13}$ C NMR (126 MHz, CDCl $) \delta 215.12,90.40(\mathrm{~d}, J=185.9 \mathrm{~Hz}), 47.28(\mathrm{~d}, J=10.4 \mathrm{~Hz}), 42.28(\mathrm{~d}$, $J=20.2 \mathrm{~Hz}), 41.79(\mathrm{~d}, J=17.7 \mathrm{~Hz}), 38.17(\mathrm{~d}, J=2.2 \mathrm{~Hz}), 30.66$ (d, $J=9.9 \mathrm{~Hz})$.

${ }^{19}$ F NMR (282 MHz, $\left.\mathrm{CDCl}_{3}\right) \delta-140.2(\mathrm{~m})$.<smiles>FCCCc1ccccc1</smiles>

\section{(3-Fluoropropyl)benzene (28)}

Prepared following the general procedure using benzophenone (5 mol\%), NFSI (3 equiv.), $\mathrm{Na}_{2} \mathrm{HPO}_{4} \cdot 7 \mathrm{H}_{2} \mathrm{O}$ (2 equiv.), (TMS) ${ }_{3} \mathrm{SiOH}$ (1.75 equiv.), (3-bromopropyl)benzene (100 mg, 0.5 mmol, 1 equiv.), and $\mathrm{MeCN} / \mathrm{H}_{2} \mathrm{O}(1: 1,5 \mathrm{~mL})$ under blue LED irradiation for 6 hours. Pure product could not be obtained due to product volatility. As such ${ }^{19} \mathrm{~F}$ NMR and crude ${ }^{1} \mathrm{H}$ NMR are provided. The NMR data are consistent with those reported in the literature ${ }^{20}$. $\left(24 \%{ }^{19} \mathrm{~F}\right.$ NMR yield against internal standard)

${ }^{19}$ F NMR (282 MHz, $\left.\mathrm{CDCl}_{3}\right) \delta-220.07(\mathrm{~m})$

${ }^{1}$ H NMR (400 MHz, CDCl$) \delta 7.33-7.27(\mathrm{~m}, 2 \mathrm{H}), 7.23$ - 7.27 (m, 3H), $4.46(\mathrm{dt}, J=47.2,6.0$ $\mathrm{Hz}, 2 \mathrm{H}), 2.76(\mathrm{t}, J=7.5 \mathrm{~Hz}, 2 \mathrm{H}), 2.07-1.93(\mathrm{~m}, 2 \mathrm{H})$.<smiles>COC(=O)c1ccc(C(C)F)cc1</smiles>

\section{Methyl 4-(1-fluoroethyl)benzoate (29)}

Prepared following the general procedure using benzophenone (5 mol\%), NFSI (3 equiv.), $\mathrm{Na}_{2} \mathrm{HPO}_{4} \cdot 7 \mathrm{H}_{2} \mathrm{O}$ (2 equiv.), (TMS) ${ }_{3} \mathrm{SiOH}$ (1.75 equiv.), (3-bromopropyl)benzene (122 mg, 0.5 mmol, 1 equiv.), and $\mathrm{MeCN} / \mathrm{H}_{2} \mathrm{O}(1: 1,5 \mathrm{~mL})$ under blue LED irradiation for 4 hours. The pure product was obtained as a colorless oil (25 $\mathrm{mg}, 27 \%$ yield) after purification by flash column chromatography. The NMR data are consistent with those reported in the literature ${ }^{21}$.

${ }^{1}$ H NMR (500 MHz, $\left.\mathbf{C D C l}_{3}\right) \delta 8.08-8.02(\mathrm{~m}, 2 \mathrm{H}), 7.44-7.39(\mathrm{~m}, 2 \mathrm{H}), 5.68(\mathrm{dq}, J=47.6,6.5$ $\mathrm{Hz}, 1 \mathrm{H}), 3.92$ (s, 3H), $1.65(\mathrm{dd}, J=24.0,6.5 \mathrm{~Hz}, 3 \mathrm{H})$. 
${ }^{13}$ C NMR (126 MHz, CDCl $) \delta 166.90,146.63(\mathrm{~d}, J=19.6 \mathrm{~Hz}), 129.97,125.05(\mathrm{~d}, J=7.2 \mathrm{~Hz})$, $90.50(\mathrm{~d}, J=169.6 \mathrm{~Hz}), 52.33,23.16(\mathrm{~d}, J=24.7 \mathrm{~Hz})$.

${ }^{19}$ F NMR (376 MHz, $\left.\mathbf{C D C l}_{3}\right) \delta-171.19(\mathrm{dq}, J=47.9,23.9 \mathrm{~Hz})$.<smiles>FC1CCC([Co])CC1</smiles>

\section{Benzyl 4-fluoropiperidine-1-carboxylate (9)}

Prepared following the general procedure using benzophenone (2.5 mol\%), NFSI (3 equiv.), $\mathrm{K}_{3} \mathrm{PO}_{4}$ (2 equiv.), (TMS) ${ }_{3} \mathrm{SiOH}$ (1.5 equiv.), Benzyl 4-bromopiperidine-1-carboxylate (149 mg, 0.5 mmol, 1 equiv.), and $\mathrm{MeCN} / \mathrm{H}_{2} \mathrm{O}(1: 1,5 \mathrm{~mL})$ under blue LED irradiation for 4 hours. The product was obtained as a clear oil (106 mg, 89\% yield) after purification by flash column chromatography and reverse-phase chromatography.

${ }^{1}$ H NMR (500 MHz, CDCl $\left.{ }_{3}\right) \delta 7.40-7.29(\mathrm{~m}, 5 \mathrm{H}), 5.13(\mathrm{~s}, 2 \mathrm{H}), 4.90-4.74(\mathrm{~m}, 1 \mathrm{H}), 3.56(\mathrm{~m}$, $4 \mathrm{H}), 1.83(\mathrm{~m}, 4 \mathrm{H})$.

${ }^{13}$ C NMR (126 MHz, CDCl $) \delta 155.33,136.81,128.64,128.17,128.03,87.96$ (d, $\left.J=171.2 \mathrm{~Hz}\right)$, $67.31,40.04(\mathrm{~d}, J=5.8 \mathrm{~Hz})$.

${ }^{19}$ F NMR (282 MHz, CDCl 3 ) $\delta-182.92(\mathrm{~m})$.

IR (film) $v_{\max } 2951,1670,1430,1274,1225$, and $1026 \mathrm{~cm}^{-1}$.

HRMS (ESI-TOF) m/z calcd. for $\mathrm{C}_{13} \mathrm{H}_{16} \mathrm{FNNaO}_{2}{ }^{+}\left([\mathrm{M}+\mathrm{Na}]^{+}\right)$260.10573, found 260.10528.<smiles>O=C(c1ccc(C(F)(F)F)nc1)N1CCC(F)CC1</smiles>

\section{(4-Fluoropiperidin-1-yl)(6-(trifluoromethyl)pyridin-3-yl)methanone (10)}

Prepared following the general procedure using benzophenone (2.5 mol\%), NFSI (3 equiv.), $\mathrm{Na}_{2} \mathrm{HPO}_{4} \bullet 7 \mathrm{H}_{2} \mathrm{O} \quad\left(2\right.$ equiv.), (TMS) ${ }_{3} \mathrm{SiOH} \quad(1.75$ equiv.), (4-bromopiperidin-1-yl)(6- 
(trifluoromethyl)pyridin-3-yl)methanone (169 mg, $0.5 \mathrm{mmol}, 1$ equiv.), and $\mathrm{MeCN} / \mathrm{H}_{2} \mathrm{O}(1: 1,5$ $\mathrm{mL}$ ) under blue LED irradiation for 4 hours. The pure product was obtained as a white solid (119 $\mathrm{mg}, 86 \%$ yield) after purification by flash column chromatography.

${ }^{1}$ H NMR (500 MHz, $\left.\mathbf{C D C l}_{3}\right) \delta 8.76(\mathrm{~s}, 1 \mathrm{H}), 7.94(\mathrm{dd}, J=8.0,2.1 \mathrm{~Hz}, 1 \mathrm{H}), 7.77(\mathrm{dd}, J=8.0,0.9$ $\mathrm{Hz}, 2 \mathrm{H}), 4.95(\mathrm{dtt}, J=47.6,5.6,3.0 \mathrm{~Hz}, 1 \mathrm{H}), 4.27-3.31(\mathrm{~m}, 4 \mathrm{H}), 1.95(\mathrm{~m}, 4 \mathrm{H})$.

${ }^{13}$ C NMR (126 MHz, CDCl $) \delta 166.37,149.04$ (q, $\left.J=35.2 \mathrm{~Hz}\right), 147.90,136.41,134.43,121.13$ $(\mathrm{q}, J=274.3 \mathrm{~Hz}), 120.54(\mathrm{q}, J=2.7 \mathrm{~Hz}), 86.92(\mathrm{~d}, J=171.9 \mathrm{~Hz}), 43.52,38.12,31.72(\mathrm{~d}, J=20.4$ $\mathrm{Hz}), 30.63(\mathrm{~d}, J=20.3 \mathrm{~Hz})$.

${ }^{19}$ F NMR (282 MHz, CDCl $) \delta-68.14(\mathrm{~s}, 3 \mathrm{~F}),-184.55(\mathrm{~m}, 1 \mathrm{~F})$.

IR (film) $v_{\max } 2949,1636,1444,1336,1137,1082,1027 \mathrm{~cm}^{-1}$.

HRMS (ESI-TOF) m/z calcd. for $\mathrm{C}_{12} \mathrm{H}_{13} \mathrm{~F}_{4} \mathrm{~N}_{2} \mathrm{O}^{+}\left([\mathrm{M}+\mathrm{H}]^{+}\right)$277.09585, found 277.09508.

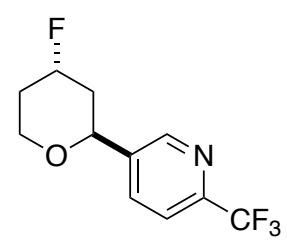

\section{5-(4-fluorotetrahydro-2H-pyran-2-yl)-2-(trifluoromethyl)pyridine (11)}

Prepared following the general procedure using benzophenone (2.5 mol\%), NFSI (3 equiv.), $\mathrm{K}_{3} \mathrm{PO}_{4} \quad$ (2 equiv.), (TMS) ${ }_{3} \mathrm{SiOH}$ (1.75 equiv.), 5-(4-bromotetrahydro-2H-pyran-2-yl)-2(trifluoromethyl)pyridine (155 mg, $0.5 \mathrm{mmol}, 1$ equiv.), and $\mathrm{MeCN} / \mathrm{H}_{2} \mathrm{O}(1: 1,5 \mathrm{~mL})$ under blue LED irradiation for 4 hours. The product was obtained as a white solid (100 $\mathrm{mg}, 80 \%$ yield, 3:1 d.r.) after purification by flash column chromatography. The diastereomers were separated by reverse-phase column chromatography for further characterization.

Note: The major diastereomer was assigned as trans by comparison to the ${ }^{19} \mathrm{~F}$ NMR spectra of isomers of an analogous compound. ${ }^{22}$

${ }^{1}$ H NMR (500 MHz, $\mathbf{C D C l}_{3}$ ) (major diastereomer) $\delta 8.69(\mathrm{~s}, 1 \mathrm{H}), 7.87(\mathrm{dd}, J=8.3,2.1 \mathrm{~Hz}, 1 \mathrm{H})$, $7.67(\mathrm{~d}, J=8.1 \mathrm{~Hz}, 1 \mathrm{H}), 5.11(\mathrm{dt}, J=47.8,2.9 \mathrm{~Hz}, 1 \mathrm{H}), 4.88(\mathrm{dd}, J=11.9,2.4 \mathrm{~Hz}, 1 \mathrm{H}), 4.09-$ $3.98(\mathrm{~m}, 2 \mathrm{H}), 2.26-2.18(\mathrm{~m}, 1 \mathrm{H}), 2.05-1.87(\mathrm{~m}, 2 \mathrm{H}), 1.76(\mathrm{dddd}, J=42.7,14.2,11.8,2.1 \mathrm{~Hz}$, $1 \mathrm{H})$. 
${ }^{13}$ C NMR (126 MHz, $\mathbf{C D C l}_{3}$ ) (major diastereomer) $\delta 147.86,147.45$ (q, $\left.J=34.8 \mathrm{~Hz}\right), 141.13$ $(\mathrm{m}), 134.73,121.66$ (q, $J=274.1 \mathrm{~Hz}), 120.37$ (q, $J=2.8 \mathrm{~Hz}), 86.26$ (d, $J=169.8), 71.54,63.24$, $38.71(\mathrm{~d}, J=20.3 \mathrm{~Hz}), 30.47(\mathrm{~d}, J=20.6 \mathrm{~Hz})$.

${ }^{19}$ F NMR (282 MHz, CDCl$)$ (major diastereomer) $\delta-67.83(\mathrm{~s}, 3 \mathrm{~F}),-186.22(\mathrm{~m}, 1 \mathrm{~F})$.

${ }^{1}$ H NMR (500 MHz, $\mathbf{C D C l}_{3}$ ) (minor diastereomer) $\delta 8.69(\mathrm{~d}, J=2.2,1 \mathrm{H}), 7.89(\mathrm{dd}, J=8.1,2.1$ $\mathrm{Hz}, 1 \mathrm{H}), 7.69(\mathrm{~d}, J=8.1 \mathrm{~Hz}, 1 \mathrm{H}), 4.85(\mathrm{dtt}, J=48.8,10.7,4.9 \mathrm{~Hz}, 1 \mathrm{H}), 4.47$ (dt, $J=11.7,2.2 \mathrm{~Hz}$, $1 \mathrm{H}), 4.29-4.21(\mathrm{~m}, 1 \mathrm{H}), 3.60(\mathrm{tt}, J=12.3,2.0 \mathrm{~Hz}, 1 \mathrm{H}), 2.40(\mathrm{dtt}, J=12.0,4.7,2.2 \mathrm{~Hz}, 1 \mathrm{H}), 2.20$ $-2.13(\mathrm{~m}, 1 \mathrm{H}), 1.94-1.82(\mathrm{~m}, 1 \mathrm{H}), 1.76-1.65(\mathrm{~m}, 1 \mathrm{H})$.

${ }^{13} \mathbf{C}$ NMR (126 MHz, $\mathbf{C D C l}_{3}$ ) (minor diastereomer) $\delta 147.89,147.72$ (q, $\left.J=34.7 \mathrm{~Hz}\right), 140.20$, $134.83,121.62$ (q, $J=274.0 \mathrm{~Hz}), 120.46$ (q, $J=2.7 \mathrm{~Hz}), 88.74(\mathrm{~d}, J=178.2), 74.99$ (d, $J=11.7$ $\mathrm{Hz}), 65.69$ (d, $J=11.9 \mathrm{~Hz}), 40.49$ (d, $J=18.1 \mathrm{~Hz}), 32.83$ (d, $J=17.8 \mathrm{~Hz})$.

${ }^{19}$ F NMR (282 MHz, $\mathbf{C D C l}_{3}$ ) (minor diastereomer) $\delta-67.86(\mathrm{~s}, 3 \mathrm{~F}),-170.56(\mathrm{~m}, 1 \mathrm{~F})$.

IR (film) $v_{\max } 2959,2871,1334,1258,1178,1136,1085,1074$, and $849 \mathrm{~cm}^{-1}$.

HRMS (ESI-TOF) $\mathrm{m} / \mathrm{z}$ calcd. for $\mathrm{C}_{11} \mathrm{H}_{12} \mathrm{~F}_{4} \mathrm{NO}^{+}\left([\mathrm{M}+\mathrm{H}]^{+}\right)$250.08495, found 250.08484 .

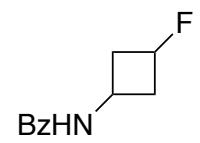

$N$-(3-Fluorocyclobutyl)benzamide (13)

Prepared following the general procedure using benzophenone (5 mol\%), NFSI (3 equiv.), $\mathrm{Na}_{2} \mathrm{HPO}_{4} \cdot 7 \mathrm{H}_{2} \mathrm{O}$ (2 equiv.), (TMS) ${ }_{3} \mathrm{SiOH}$ (1.75 equiv.), $\mathrm{N}$-(3-bromocyclobutyl)benzamide (127 mg, $0.5 \mathrm{mmol}, 1$ equiv.), and $\mathrm{MeCN} / \mathrm{H}_{2} \mathrm{O}(1: 1,5 \mathrm{~mL})$ under blue LED irradiation for 6 hours. The pure product was obtained as a white solid (40 mg, 41\% yield, 1.2:1 d.r.) after purification by flash column chromatography.

${ }^{1} \mathbf{H}$ NMR (500 MHz, $\left.\mathbf{C D C l}_{3}\right)(1.2: 1$ mixture of diastereomers) $\delta 7.75(\mathrm{~m}, 4.5 \mathrm{H}), 7.55-7.48(\mathrm{~m}$, $2 \mathrm{H}), 7.43(\mathrm{~m}, 4.5 \mathrm{H}), 6.27(\mathrm{~s}, 2 \mathrm{H}, 1 \mathrm{H}$ minor $+1 \mathrm{H}$ major), 5.26 (dtt, $J=55.9,6.7,3.3 \mathrm{~Hz}, 1 \mathrm{H}$ major), 4.86 (dp, $J=55.6,6.6 \mathrm{~Hz}, 1 \mathrm{H}$ minor), 4.72 (m, 1H major), 4.19 (m, 1H minor), 3.01 - 2.92 (m, 2H minor), 2.75 (dddd, $J=21.2,14.5,8.3,3.6 \mathrm{~Hz}, 2 \mathrm{H}$ major), 2.44 (ddt, $J=20.5,14.4,6.2 \mathrm{~Hz}$, 2H major), 2.20 (ddddd, $J=21.9,10.0,8.9,6.7,3.1 \mathrm{~Hz}, 2 \mathrm{H}$ minor).

${ }^{13}$ C NMR (126 MHz, $\mathbf{C D C l}_{3}$ ) (1.2:1 mixture of diastereomers) $\delta$ 167.41, 167.10, 134.31, 134.20, 131.84, 131.81, 128.79, 128.78, 127.02, 126.99, 86.87 (d, $J=200.1 \mathrm{~Hz}), 81.65$ (d, $J=210.9 \mathrm{~Hz})$, 
$42.01(\mathrm{~d}, J=7.9 \mathrm{~Hz}), 39.88(\mathrm{~d}, J=20.0 \mathrm{~Hz}), 38.48$ (d, $J=22.5 \mathrm{~Hz}), 35.83(\mathrm{~d}, J=22.9 \mathrm{~Hz})$.

${ }^{19}$ F NMR (282 MHz, $\mathbf{C D C l}_{3}$ ) (1.2:1 mixture of diastereomers) $\delta-167.69$ (m, 1F minor), -177.16 (m, 1F major).

IR (film) $v_{\max } 3294,2928,1633,1542,1358$, and $1308 \mathrm{~cm}^{-1}$.

HRMS (ESI-TOF) m/z calcd. for $\mathrm{C}_{11} \mathrm{H}_{13} \mathrm{FNO}^{+}\left([\mathrm{M}+\mathrm{H}]^{+}\right)$194.09757, found 194.09711.<smiles>CC(F)CCOC(=O)c1ccc(O)cc1</smiles>

\section{3-Fluorobutyl 4-hydroxybenzoate (16)}

Prepared following the general procedure using benzophenone (5 mol\%), NFSI (3 equiv.), $\mathrm{Na}_{2} \mathrm{HPO}_{4} \bullet 7 \mathrm{H}_{2} \mathrm{O}$ (2 equiv.), (TMS) ${ }_{3} \mathrm{SiOH}$ (1.75 equiv.), 3-bromobutyl 4-hydroxybenzoate (106 $\mathrm{mg}, 0.5 \mathrm{mmol}, 1$ equiv.), and $\mathrm{MeCN} / \mathrm{H}_{2} \mathrm{O}(1: 1,5 \mathrm{~mL})$ under blue LED irradiation for 4 hours. The pure product was obtained as a white solid ( $84 \mathrm{mg}, 80 \%$ yield) after purification by flash column chromatography.

${ }^{1}$ H NMR (500 MHz, CDCl $) \delta 7.98-7.94(\mathrm{~m}, 2 \mathrm{H}), 6.88-6.84(\mathrm{~m}, 2 \mathrm{H}), 5.31$ (br s, 1H), 4.87 (m, $1 \mathrm{H}), 4.49-4.38(\mathrm{~m}, 2 \mathrm{H}), 2.16-1.93(\mathrm{~m}, 2 \mathrm{H}), 1.41(\mathrm{dd}, J=23.9,6.2 \mathrm{~Hz}, 3 \mathrm{H})$.

${ }^{13}$ C NMR (126 MHz, $\left.\mathbf{C D C l}_{3}\right) \delta 166.34,159.84,132.07,122.99,115.34,88.06(\mathrm{~d}, J=165.3 \mathrm{~Hz})$, $61.05(\mathrm{~d}, J=5.4 \mathrm{~Hz}), 36.25(\mathrm{~d}, J=21.1 \mathrm{~Hz}), 21.27(\mathrm{~d}, J=22.4 \mathrm{~Hz})$.

${ }^{19}$ F NMR (282 MHz, $\left.\mathbf{C D C l}_{3}\right) \delta-175.41(\mathrm{~m})$.

IR (film) $v_{\max } 3340,2981,1684,1608,1592,1277,1166,1118,1101$, and $772 \mathrm{~cm}^{-1}$.

HRMS (ESI-TOF) m/z calcd. for $\mathrm{C}_{11} \mathrm{H}_{13} \mathrm{FNaO}_{3}{ }^{+}\left([\mathrm{M}+\mathrm{Na}]^{+}\right)$235.07409, found 235.07444.

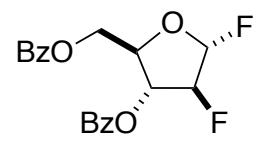

3-(Benzoyloxy)-4,5-difluorotetrahydrofuran-2-yl)methyl benzoate (20)

Prepared following the general procedure using benzophenone (2.5 mol\%), NFSI (3 equiv.), 
$\mathrm{Na}_{2} \mathrm{HPO}_{4} \bullet 7 \mathrm{H}_{2} \mathrm{O} \quad(2 \text { equiv.), (TMS) })_{3} \mathrm{SiOH} \quad(1.75$ equiv.), 3-(benzoyloxy)-5-bromo-4fluorotetrahydrofuran-2-yl)methyl benzoate (212 mg, $0.5 \mathrm{mmol}, 1$ equiv.), and $\mathrm{MeCN} / \mathrm{H}_{2} \mathrm{O}$ (1:1, $5 \mathrm{~mL}$ ) under blue LED irradiation for 2 hours. The pure product was obtained as a white solid (150 mg, 90\% yield, >20:1 d.r.) after purification by flash column chromatography.

Note: The major diastereomer was assigned by comparison to the ${ }^{1} \mathrm{H}$ and ${ }^{13} \mathrm{C}$ NMR spectra of isomers of an analogous compounds. ${ }^{23}$

${ }^{1}$ H NMR (500 MHz, $\left.\mathbf{C D C l}_{3}\right) \delta 8.06(\mathrm{~m}, 4 \mathrm{H}), 7.65$ - 7.55 (m, 2H), $7.51-7.41(\mathrm{~m}, 4 \mathrm{H}), 6.03$ (dd, $J=58.0,5.9 \mathrm{~Hz}, 1 \mathrm{H}), 5.54(\mathrm{dd}, J=21.0,3.3 \mathrm{~Hz}, 1 \mathrm{H}), 5.31(\mathrm{dd}, J=48.3,3.4 \mathrm{~Hz}, 1 \mathrm{H}), 4.83-4.75$ $(\mathrm{m}, 2 \mathrm{H}), 4.70-4.62(\mathrm{~m}, 1 \mathrm{H})$.

${ }^{13}$ C NMR (126 MHz, CDCl $) \delta$ 166.24, 165.68, 134.03, 133.37, 130.05, 129.93 (d, $\left.J=1.1 \mathrm{~Hz}\right)$, 129.59, 128.75, 128.62, 128.53, 111.76 (dd, $J=224.0,36.6 \mathrm{~Hz}), 96.70$ (dd, $J=183.6,41.6 \mathrm{~Hz})$, $84.67(\mathrm{~d}, J=1.3 \mathrm{~Hz}), 76.03(\mathrm{~d}, J=30.5 \mathrm{~Hz}), 63.39$.

${ }^{19}$ F NMR (470 MHz, $\left.\mathbf{C D C l}_{3}\right) \delta-129.33(\mathrm{dd}, J=58.7,14.6 \mathrm{~Hz}),-193.55$ (dddd, $J=48.3,20.7$, $14.3,6.0 \mathrm{~Hz})$.

IR (film) $v_{\max } 2923,1723,1266,1453$, and $1113 \mathrm{~cm}^{-1}$.

HRMS (ESI-TOF) $\mathrm{m} / \mathrm{z}$ calcd. for $\mathrm{C}_{19} \mathrm{H}_{16} \mathrm{~F}_{2} \mathrm{NaO}_{5}{ }^{+}\left([\mathrm{M}+\mathrm{Na}]^{+}\right) 385.0858$, found 385.08638 .<smiles>CC(=O)OCC1OC(n2ccc(=O)n(CCC(C)F)c2=O)C(OC(C)=O)[C@@H]1OC(C)=O</smiles>

\section{2-(Acetoxymethyl)-5-(3-(3-fluorobutyl)-2,4-dioxo-3,4-dihydropyrimidin-1(2H)-}

\section{yl)tetrahydrofuran-3,4-diyl diacetate (21)}

Prepared following the general procedure using benzophenone (2.5 mol\%), NFSI (3 equiv.), $\mathrm{K}_{3} \mathrm{PO}_{4}$ (2 equiv.), (TMS) ${ }_{3} \mathrm{SiOH}$ (1.75 equiv.), 2-(Acetoxymethyl)-5-(3-(3-bromobutyl)-2,4-dioxo3,4-dihydropyrimidin-1(2H)-yl)tetrahydrofuran-3,4-diyl diacetate (253 mg, $0.5 \mathrm{mmol}, 1$ equiv.), and $\mathrm{MeCN} / \mathrm{H}_{2} \mathrm{O}(1: 1,5 \mathrm{~mL})$ under blue LED irradiation for 4 hours. The pure product was obtained as a clear gel (187 mg, 84\% yield, 1:1 d.r.) after purification by flash column chromatography.

${ }^{1}$ H NMR (500 MHz, $\left.\mathbf{C D C l}_{3}\right)(1: 1$ mixture of diastereomers) $\delta 7.34(\mathrm{~m}, 1 \mathrm{H}), 5.96(\mathrm{~d}, J=8.2,1 \mathrm{H})$, $5.77(\mathrm{~d}, J=8.2 \mathrm{~Hz}, 1 \mathrm{H}), 5.31(\mathrm{~m}, 2 \mathrm{H}), 4.80-4.61(\mathrm{~m}, 1 \mathrm{H}), 4.31(\mathrm{~m}, 3 \mathrm{H}), 4.13-3.93(\mathrm{~m}, 2 \mathrm{H})$, $2.10(\mathrm{~s}, 3 \mathrm{H}), 2.08(\mathrm{~s}, 3 \mathrm{H}), 2.07(\mathrm{~s}, 3 \mathrm{H}), 2.02-1.72(\mathrm{~m}, 2 \mathrm{H}), 1.31(\mathrm{dd}, J=23.8,6.2 \mathrm{~Hz}, 3 \mathrm{H})$. 
${ }^{13}$ C NMR (126 MHz, $\mathbf{C D C l}_{3}$ ) (1:1 mixture of diastereomers) $\delta$ 170.18, 169.64, 169.62, 162.14, 150.75, 137.37, 102.75, $89.82(\mathrm{~d}, J=9.8 \mathrm{~Hz}$ ) (diastereomer 1), 88.78 (diastereomer 1), 88.75 (diastereomer 2), $88.51(\mathrm{~d}, J=9.8 \mathrm{~Hz}$ ) (diastereomer 2), 79.70, 73.02, 69.97 (diastereomer 1), 69.95 (diastereomer 2), 62.97 (diastereomer 1), 62.95 (diastereomer 2), 37.94 (d, $J=5.0 \mathrm{~Hz}$ ) (diastereomer 1), 37.89 (d, $J=5.0 \mathrm{~Hz}$ ) (diastereomer 2), $34.72(\mathrm{~d}, J=4.9 \mathrm{~Hz})($ diastereomer 1), $34.55(\mathrm{~d}, J=5.0 \mathrm{~Hz}$ ) (diastereomer 2), $21.14(\mathrm{~d}, J=3.8 \mathrm{~Hz})($ diastereomer 1$), 20.96(\mathrm{~d}, J=3.9$ $\mathrm{Hz}$ ) (diastereomer 2), 20.81, 20.52, 20.47.

${ }^{19}$ F NMR (470 MHz, $\left.\mathbf{C D C l}_{3}\right)$ (1:1 mixture of diastereomers) $\delta-174.45(\mathrm{~m})$.

IR (film) $v_{\max } 1748,1712,1669,1458,1375,1225$, and $1049 \mathrm{~cm}^{-1}$.

HRMS (ESI-TOF) m/z calcd. for $\mathrm{C}_{19} \mathrm{H}_{25} \mathrm{FN}_{2} \mathrm{NaO}^{+}\left([\mathrm{M}+\mathrm{Na}]^{+}\right)$467.14363, found 467.14258.
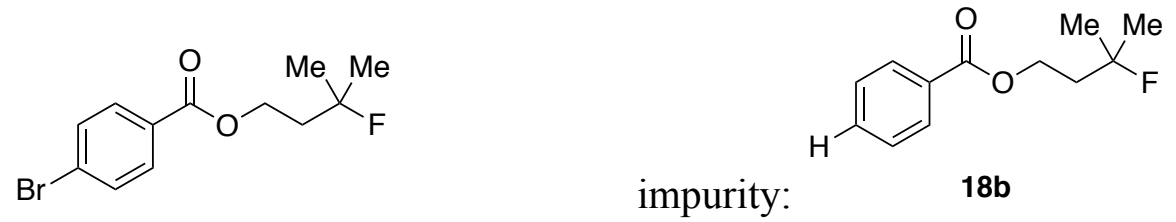

\section{3-Fluoro-3-methylbutyl 4-bromobenzoate (26)}

Prepared following the general procedure using benzophenone (2.5 mol\%), NFSI (3 equiv.), $\mathrm{Na}_{2} \mathrm{HPO}_{4} \bullet 7 \mathrm{H}_{2} \mathrm{O}$ (2 equiv.), (TMS) ${ }_{3} \mathrm{SiOH}$ (1.5 equiv.), 3-bromo-3-methylbutyl 4-bromobenzoate (175 mg, $0.45 \mathrm{mmol}, 1$ equiv.), and $\mathrm{MeCN} / \mathrm{H}_{2} \mathrm{O}(1: 1,5 \mathrm{~mL})$ under blue LED irradiation for 4 hours. The product was obtained as a white solid (94 mg, 72\% yield, 84\% pure with 13\% of impurity $18 \mathrm{~b})$ after purification by flash column chromatography. $\left(63 \%{ }^{19} \mathrm{~F}\right.$ NMR yield against internal standard)

${ }^{1}$ H NMR (500 MHz, CDCl $) \delta 7.84-7.80(\mathrm{~m}, 2 \mathrm{H}), 7.53-7.49(\mathrm{~m}, 2 \mathrm{H}), 4.40(\mathrm{t}, J=6.8 \mathrm{~Hz}, 2 \mathrm{H})$, 2.04 (dt, $J=19.6,6.8 \mathrm{~Hz}, 2 \mathrm{H}), 1.37$ (d, $J=21.5 \mathrm{~Hz}, 6 \mathrm{H})$.

${ }^{13}$ C NMR (126 MHz, CDCl $) \delta 165.92,131.89,131.22,129.25,128.24,94.32(\mathrm{~d}, J=166.2 \mathrm{~Hz})$, $61.33(\mathrm{~d}, J=6.0 \mathrm{~Hz}), 39.90(\mathrm{~d}, J=23.1 \mathrm{~Hz}), 27.21(\mathrm{~d}, J=24.7 \mathrm{~Hz})$.

${ }^{19}$ F NMR (282 MHz, CDCl$\left._{3}\right) \delta-138.46(\mathrm{~m})$.

IR (film) $v_{\max } 2981,1721,1591,1273,1116,1103$ and $756 \mathrm{~cm}^{-1}$.

HRMS (ESI-TOF) m/z calcd. for $\mathrm{C}_{12} \mathrm{H}_{14} \mathrm{BrFNaO}_{2}{ }^{+}\left([\mathrm{M}+\mathrm{Na}]^{+}\right) 311.00534$, found 311.00485 . 
<smiles>CC(C)(F)CCOC(=O)c1ccc(C=O)cc1</smiles>

\section{3-Fluoro-3-methylbutyl 4-formylbenzoate (27)}

Prepared following the general procedure using benzophenone (5 mol\%), NFSI (3 equiv.), $\mathrm{Na}_{2} \mathrm{HPO}_{4} \cdot 7 \mathrm{H}_{2} \mathrm{O}$ (2 equiv.), (TMS) ${ }_{3} \mathrm{SiOH}$ (1.75 equiv.), 3-bromo-3-methylbutyl 4-formylbenzoate (119 mg, $0.5 \mathrm{mmol}, 1$ equiv.), and $\mathrm{MeCN} / \mathrm{H}_{2} \mathrm{O}$ (1:1, $5 \mathrm{~mL}$ ) under blue LED irradiation for 4 hours. The pure product was obtained as a white solid (56 $\mathrm{mg}, 47 \%$ yield) after purification by flash column chromatography. $\left(82 \%{ }^{19} \mathrm{~F}\right.$ NMR yield against internal standard due to product instability during purification)

${ }^{1}$ H NMR (500 MHz, $\left.\mathbf{C D C l}_{3}\right) \delta 10.10(\mathrm{~s}, 1 \mathrm{H}), 8.21-8.17(\mathrm{~m}, 2 \mathrm{H}), 7.98-7.93(\mathrm{~m}, 2 \mathrm{H}), 4.52(\mathrm{t}, J$ $=6.8 \mathrm{~Hz}, 2 \mathrm{H}), 2.14(\mathrm{dt}, J=19.7,6.8 \mathrm{~Hz}, 2 \mathrm{H}), 1.45(\mathrm{~d}, J=21.4 \mathrm{~Hz}, 6 \mathrm{H})$

${ }^{13}$ C NMR (126 MHz, CDCl $)$ ) $\delta$ 191.82, 165.63, 139.28, 135.28, 130.29, 129.69, 94.31 (d, $J=$ $166.3 \mathrm{~Hz}), 61.69$ (d, $J=5.9 \mathrm{~Hz}), 39.83(\mathrm{~d}, J=23.0 \mathrm{~Hz}), 27.21(\mathrm{~d}, J=24.6 \mathrm{~Hz})$.

${ }^{19}$ F NMR (282 MHz, CDCl $) \delta-138.66$

IR (film) $v_{\max } 2983,1706,1276,1202,1117,1106$, and $759 \mathrm{~cm}^{-1}$.

HRMS (ESI-TOF) m/z calcd. for $\mathrm{C}_{13} \mathrm{H}_{16} \mathrm{FO}_{3}{ }^{+}\left([\mathrm{M}+\mathrm{H}]^{+}\right)$239.1078, found 239.10785.

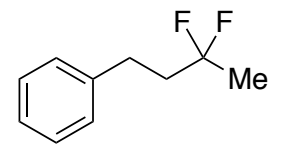

\section{(3,3-Difluorobutyl)benzene (30)}

Prepared following the general procedure using benzophenone (5 mol\%), NFSI (3.75 equiv.), $\mathrm{Na}_{2} \mathrm{HPO}_{4} \cdot 7 \mathrm{H}_{2} \mathrm{O}$ (2.5 equiv.), (TMS) ${ }_{3} \mathrm{SiOH}$ (2.2 equiv.), (3,3-dibromobutyl)benzene (146 mg, 0.5 mmol, 1 equiv.), and $\mathrm{MeCN} / \mathrm{H}_{2} \mathrm{O}(1: 1,5 \mathrm{~mL})$ under blue LED irradiation for 6 hours. The pure product was obtained as a colorless oil (61 mg, 72\% yield) after purification by flash column chromatography. 
${ }^{1}$ H NMR (500 MHz, CDCl $) \delta 7.31(\mathrm{~m}, 2 \mathrm{H}), 7.24-7.19(\mathrm{~m}, 3 \mathrm{H}), 2.84-2.80(\mathrm{~m}, 2 \mathrm{H}), 2.23-$ $2.11(\mathrm{~m}, 2 \mathrm{H}), 1.65(\mathrm{t}, J=18.4 \mathrm{~Hz}, 3 \mathrm{H})$.

${ }^{13}$ C NMR (126 MHz, $\left.\mathbf{C D C l}_{3}\right) \delta$ 140.77, 128.71, 128.41, 126.35, 123.90 (t, $\left.J=238.2 \mathrm{~Hz}\right), 39.97$ (t, $J=25.5 \mathrm{~Hz}), 29.00(\mathrm{t}, J=5.1 \mathrm{~Hz}), 23.60(\mathrm{t}, J=27.9 \mathrm{~Hz})$.

${ }^{19}$ F NMR (470 MHz, $\left.\mathbf{C D C l}_{3}\right) \delta-91.35$ (qt, $\left.J=18.5,15.8 \mathrm{~Hz}\right)$.

IR (film) $v_{\max } 1392,1240,1220,1068,901 \mathrm{~cm}^{-1}$.

HRMS (GC-QTOF) m/z calcd. $\mathrm{C}_{10} \mathrm{H}_{12} \mathrm{~F}_{2}{ }^{++}\left([\mathrm{M}]^{\bullet+}\right)$ 170.09016, found 170.08985 .

Additional Substrates (analyzed by ${ }^{19}$ F NMR due to substrate volatility):<smiles>CCC#CCC(C)F</smiles>
$52 \%{ }^{19} \mathrm{~F}$ NMR yield

6-fluorohept-3-yne<smiles>FC1C=CCCC1</smiles>
$0 \%{ }^{19} \mathrm{~F}$ NMR yield

\section{3-fluorocyclohex-1-ene}




\section{Mechanistic Studies}

\begin{tabular}{cc}
\hline Conditions & $\begin{array}{c}\text { NFSI } \\
\text { Remaining }\end{array}$ \\
\hline $\mathrm{NFSI}$ (light) & $100 \%$ \\
$\mathrm{NFSI}+$ benzophenone (light) & $100 \%$ \\
$\mathrm{NFSI}+\mathrm{SiOH}$ (dark) & $100 \%$ \\
$\mathrm{NFSI}+\mathrm{SiOH}$ (light) & $66 \%$ \\
$\mathrm{NFSI}+\mathrm{SiOH}+$ benzophenone (light) & $15 \%$ \\
\hline $\mathrm{NFSI}+\mathrm{SiOH}+$ benzophenone $+\mathrm{K}_{3} \mathrm{PO}_{4}$ (light) & $0 \%$
\end{tabular}

Figure S4. Control experiments in the absence of alkyl bromides

Reactions concentrations of each component is as outlined Procedure for Optimization Studies (Section 2). Reactions were run for 2 hours.

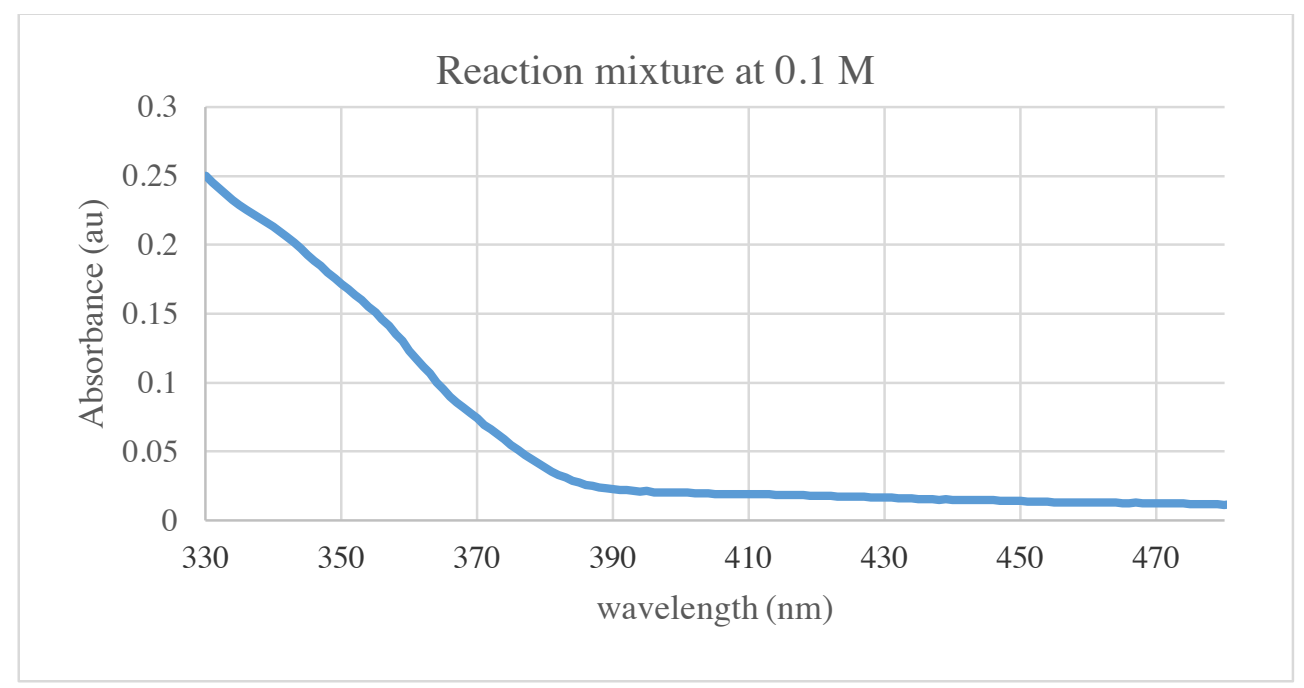

Figure S5. UV-Vis spectrum of standard reaction mixture at $0.1 \mathrm{M}$. 
A UV-Vis of the reaction mixture before irradiation was obtained in $\mathrm{MeCN}$ given the heterogeneity of the solution in $\mathrm{MeCN} / \mathrm{H}_{2} \mathrm{O}(1: 1)$. No peaks are present $>400 \mathrm{~nm}$ (excluding baseline benzophenone absorption), indicating that there are no new light-absorbing species formed at the start of the reaction (Figure S5).

Note: In the heterogeneous reaction mixture containing all reaction components in $\mathrm{MeCN} / \mathrm{H}_{2} \mathrm{O}$ (1:1), the concentration of alkyl bromide substrate is approximately equal to that of NFSI in the organic layer.

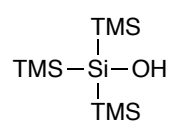

super silanol

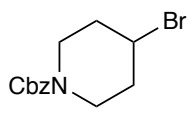

alkyl bromide

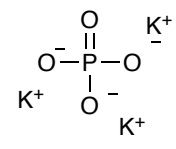

base

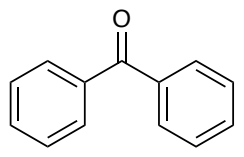

benzophenone
Conditions

no benzophenone

with benzophenone alkyl bromide

remaining

$100 \%$

$99 \%$

Figure S6. Control experiments in the absence of NFSI

Reactions concentrations of each component is as outlined Procedure for Optimization Studies (Section 2). Reactions were run for 4 hours. 


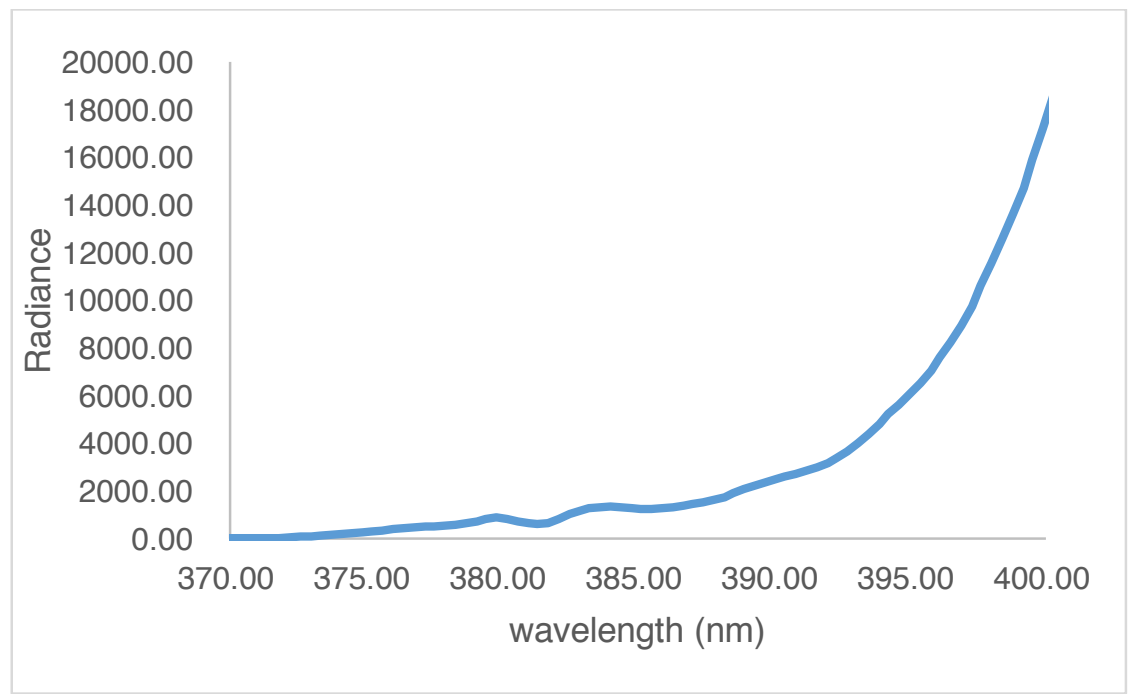

Figure S7. Emission Spectrum of 440 nm Kessil lamps (from 370 to $400 \mathrm{~nm}$ )

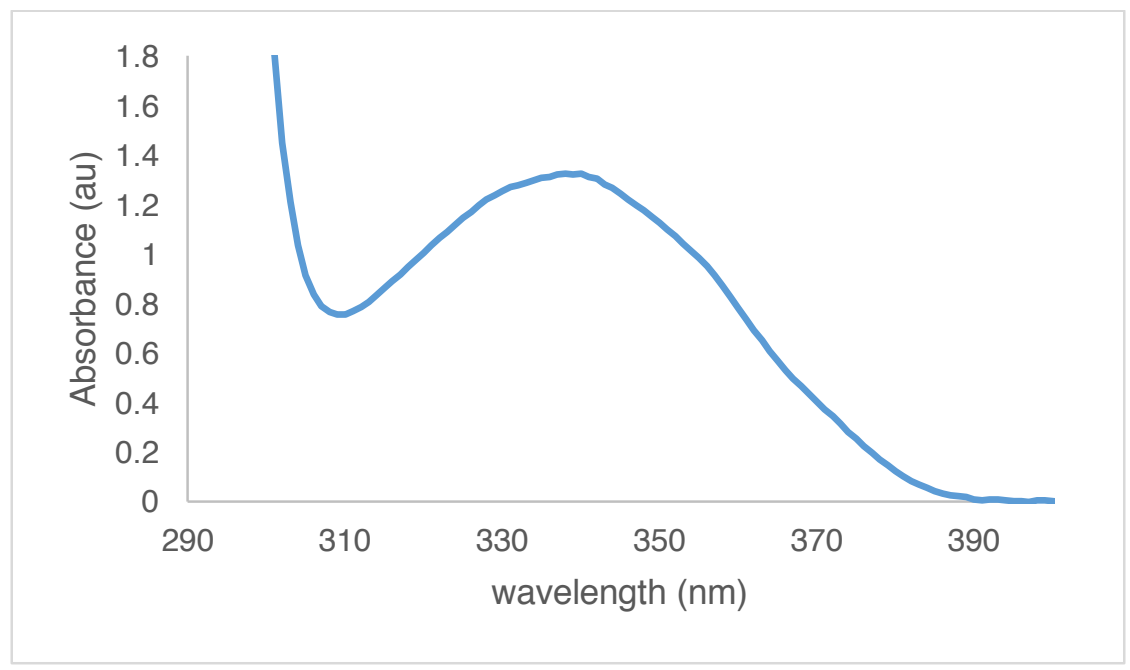

Figure S8. UV-Vis spectrum of benzophenone at $0.025 \mathrm{M}$ in $\mathrm{MeCN}$

There is a small degree of overlap between the emission of the blue Kessil lamps employed and the absorption of benzophenone. 


\section{Quantum Yield Determination}

For the full details of this quantum yield determination procedure, the recent publication by our laboratory should be consulted. ${ }^{24}$ Photon flux was determined to be $(4.0 \pm 0.3) \times 10^{-8}$ einstein $\cdot \mathrm{s}^{-1}$. The model reaction as outlined in Procedure for Optimization Studies was performed in duplicate in the $402 \mathrm{~nm}$ LED setup at room temperature. Aliquots were taken from each sample after one minute, and yields of $13 \%$ and $15 \%$ were determined by ${ }^{19} \mathrm{~F}$ NMR. The reaction without photocatalyst at this time point gives $0 \%$ yield.

Next, the absorbance of benzophenone at $402 \mathrm{~nm}$ at the reaction concentration $\left(2.5 \times 10^{-3} \mathrm{M}\right)$ was calculated, using the slope of graph in Figure S7, determined from higher concentrations because the absorbance at $2.5 \mathrm{mM}$ was too low to measure directly.

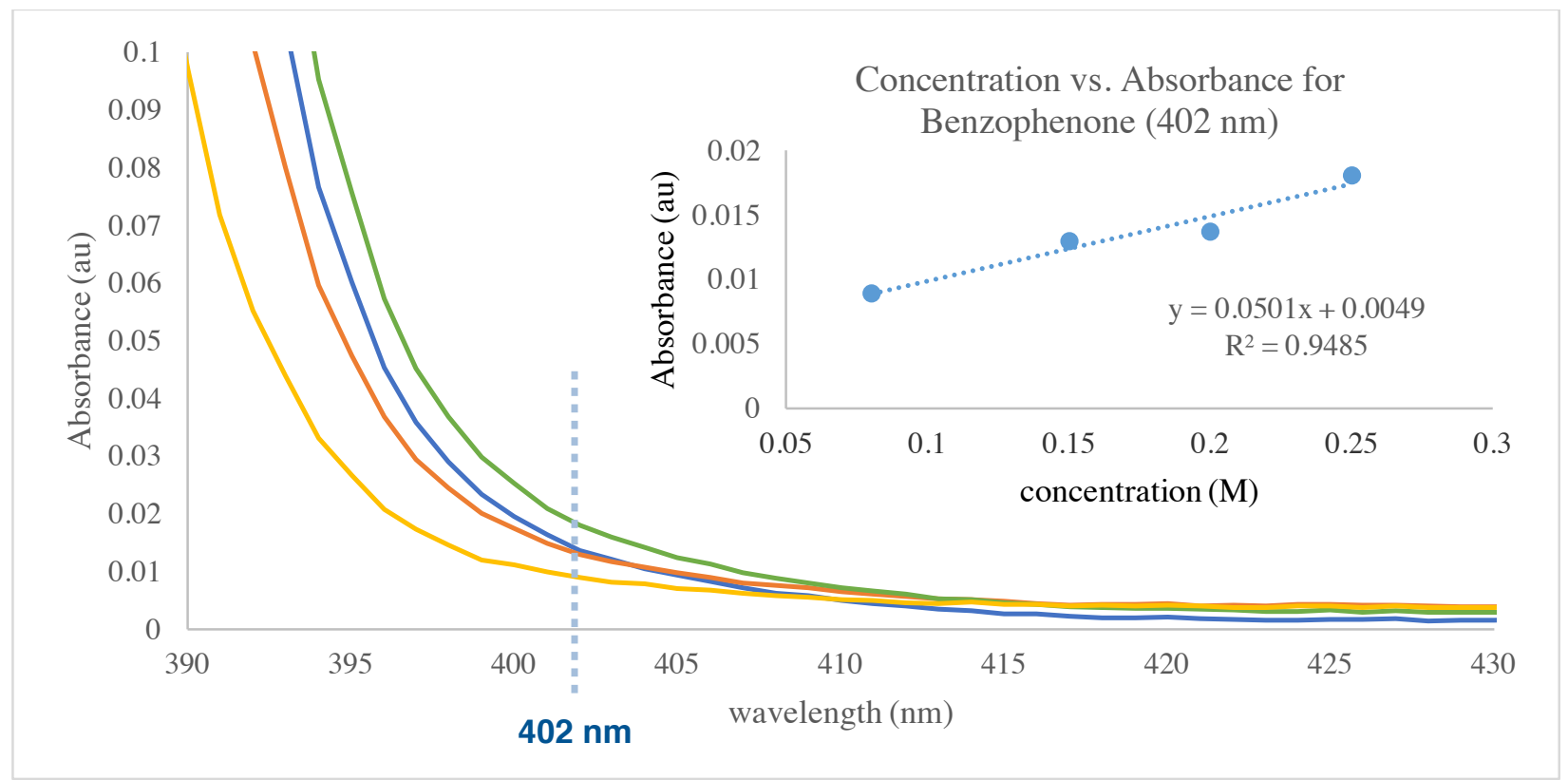

Figure S9. UV-Vis spectra of benzophenone at increasing concentrations in MeCN. The absorbance at $402 \mathrm{~nm}$ vs. concentration was plotted (inset).

The absorbance of benzophenone at the reaction concentration was next extrapolated to be $\mathrm{A}=$ $1.25 \times 10^{-4}$, such that benzophenone in $\mathrm{MeCN}$ absorbs $\mathrm{F}=1-10^{-\mathrm{A}}=0.0288 \%$ of the incident light. The quantum yield of the reaction can then be estimated using:

$$
\phi=\frac{\text { reaction yield }}{\text { photon flux } * t * \mathrm{~F}}
$$


Using the yields obtained after one minute (3600 seconds), we estimate that

$$
\phi=1020 \pm 106
$$

\section{Cyclic Voltammogram:}

$\mathrm{PhO}_{2} \mathrm{~S}_{-\overline{\mathrm{N}}_{+}^{-}} \mathrm{SO}_{2} \mathrm{Ph}$
$\mathrm{Na}$

Sodium dibenzenesulfonimide was prepared according to literature procedure. ${ }^{25}$

Sample was prepared with substrate concentration of $6.67 \mathrm{mM}$ (with 100 equiv. $\mathrm{n}-\mathrm{Bu}_{4} \mathrm{PF}_{6}$ as electrolyte) in MeCN. Data was collected at a scan rate of $0.1 \mathrm{~V} / \mathrm{s}$. $\mathrm{E}_{\mathrm{pa}}\left[\left(\mathrm{PhO}_{2} \mathrm{~S}\right)_{2} \mathrm{~N}^{-} /\left(\mathrm{PhO}_{2} \mathrm{~S}\right)_{2} \mathrm{~N}^{\bullet}\right]=$ $1.98 \mathrm{~V}$.

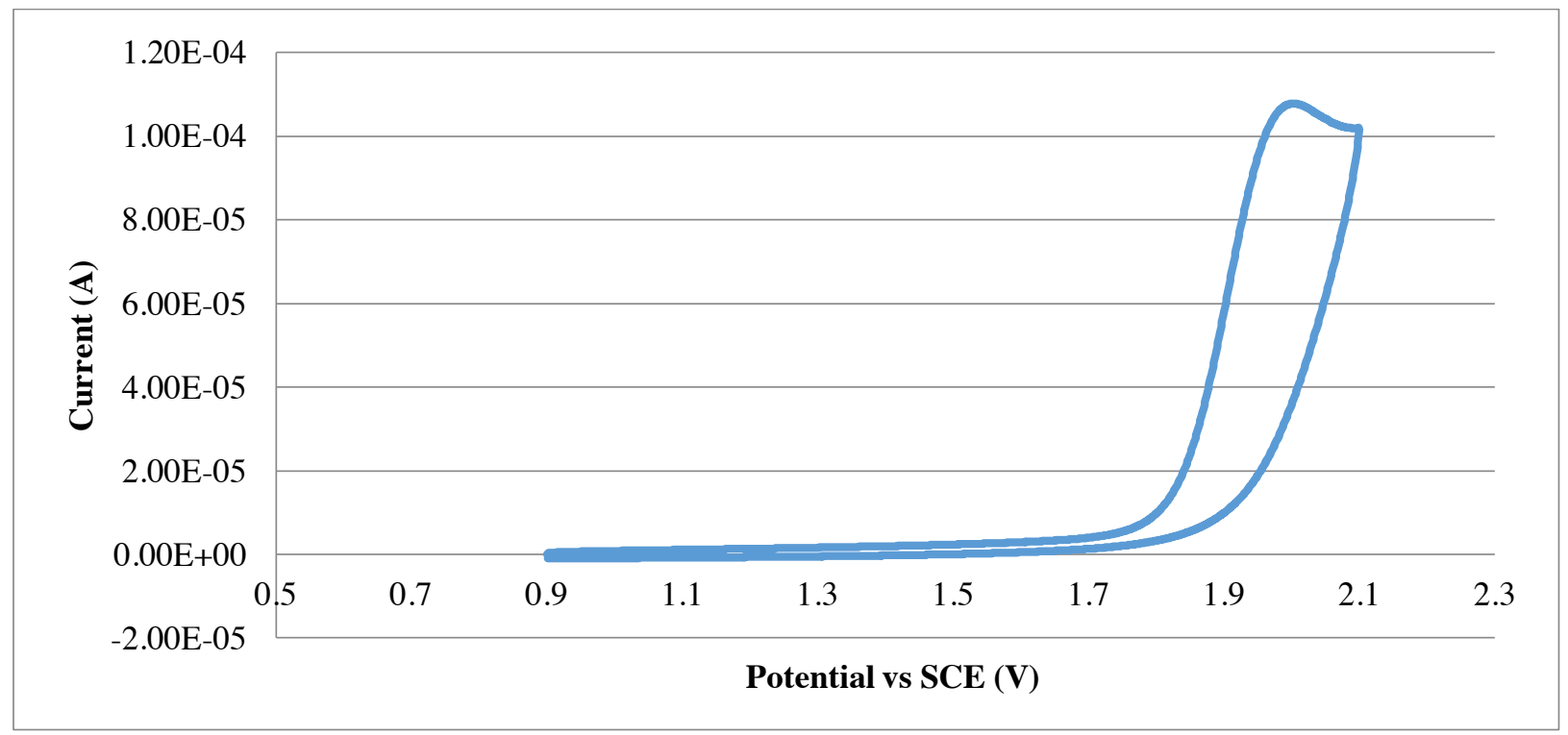

Figure S10. Cyclic voltammogram of $\left(\mathrm{SO}_{2} \mathrm{Ph}\right)_{2} \mathrm{NNa}$ in $\mathrm{MeCN}$. 


\section{Computational Studies}

\section{Computational Methods}

All computations were performed in Gaussian 09. ${ }^{26}$ Molecular geometries were optimized using the M06-2X ${ }^{27}$ functional employing the 6-31G(d) basis set. Solvation effects were included in the geometry optimizations and modeled using the $\mathrm{SMD}^{28}$ solvation model. Frequency calculations were carried out at the same level of theory as for geometry optimization to confirm the stationary points as either minima (no imaginary frequencies) or saddle points (one imaginary frequency) on the potential energy surface, and to obtain thermal corrections to the Gibbs free energies at $298 \mathrm{~K}$. Intrinsic reaction coordinate (IRC) calculations were performed to ensure that the saddle points found were true transition states connecting the reactants and the products. Single-point energies were calculated with the M06-2X functional and the 6$311++\mathrm{G}(\mathrm{d}, \mathrm{p})$ basis set. Molecular structures were visualized using CYLview. ${ }^{29}$ Monte Carlo conformational searches were performed with the Merck molecular force field (MMFF) implemented in Spartan '16 to ensure that the lowest energy conformations of intermediates and transition states are presented.

\section{Kinetic Selectivity of Radical Chain Propagation}

With (TMS) $)_{3} \mathrm{SiH}$ or (TES) $)_{3} \mathrm{SiH}$ as the silyl radical precursor, either the tris(trimethylsilyl)silyl radical $\mathbf{3 1}$ or the trimethylsilyl radical $\mathbf{3 2}$ can be envisioned to act as the bromine abstractor (Figure S8).

The barrier of fluorine abstraction from the N-F bond of NFSI by tris(trimethylsilyl)silyl radical 31 is calculated to be $1.9 \mathrm{kcal} / \mathrm{mol}$ higher than bromine abstraction from a simple secondary alkyl bromide. This result is in agreement with the experimentally observed kinetic selectivity for $\mathrm{C}-\mathrm{Br}$ bonds (in alkyl bromides) over N-F bonds (in NFSI). For trimethylsilyl radical 32, the kinetic selectivity for $\mathrm{C}-\mathrm{Br}$ abstraction is even more pronounced with a 2.9 $\mathrm{kcal} / \mathrm{mol}$ difference in free energies of activation. 
(a)

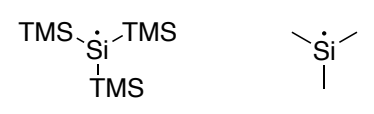

$31 \quad 32$

(b)
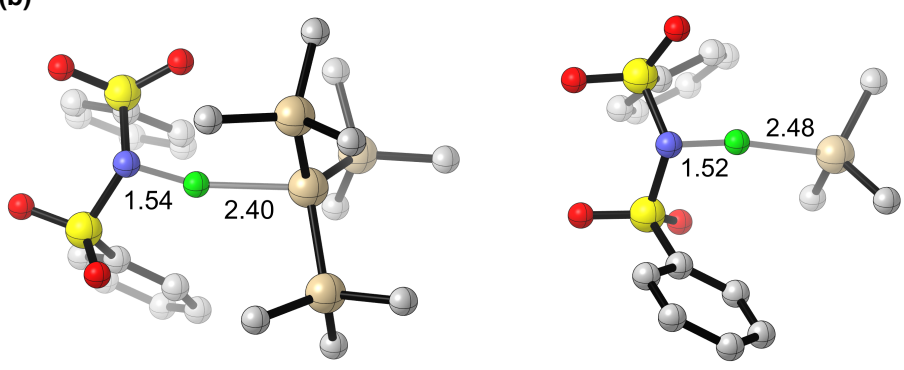

TS-A

N-F Abstraction by 31

$\Delta \mathrm{G}^{\ddagger}=+13.1 \mathrm{kcal} / \mathrm{mol}$

Charge transfer (31 to NFSI): 0.05

TS-B

N-F Abstraction by 32

$\Delta \mathrm{G}^{\ddagger}=+12.2 \mathrm{kcal} / \mathrm{mol}$

Charge transfer (32 to NFSI): 0.07
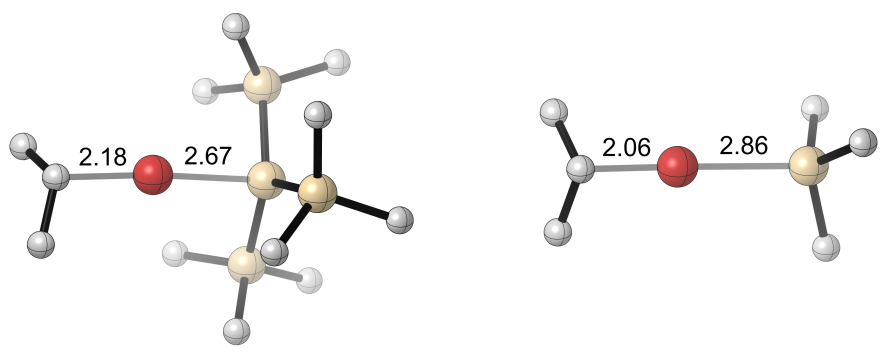

TS-C

C-Br Abstraction by 31

$\Delta \mathrm{G}^{\ddagger}=+11.2 \mathrm{kcal} / \mathrm{mol}$

Charge transfer (31 to RBr): 0.12

TS-C C-Br Abstraction by 32

$$
\Delta \mathrm{G}^{\ddagger}=+9.3 \mathrm{kcal} / \mathrm{mol}
$$

Charge transfer (32 to RBr): 0.12

Figure S11. (a) Possible silyl radicals involved in chain mechanism. (b) Transition states for N$\mathrm{F}$ and $\mathrm{C}-\mathrm{Br}$ abstraction by silyl radicals 31 and 32 at the M06-2X/6-311++G(d,p)//M06-2X/6$31 \mathrm{G}(\mathrm{d})$ level of theory. Hydrogen atoms are omitted for clarity. Hirshfeld charges were calculated at the M06-2X/6-31G(d) level of theory.

The four TSs in Figure S11 are all early transition states, with long forming bond distances and short breaking bond distances. Calculations of Hirshfeld charge distributions showed a charge transfer component of $0.12 \mathrm{e}$ from the radical to the substrate in the $\mathrm{C}-\mathrm{Br}$ abstractions. This value ranges between $0.05-0.07$ e for the $\mathrm{N}-\mathrm{F}$ abstractions. The higher volume of charge transfer in the $\mathrm{C}-\mathrm{Br}$ abstractions may indicate that the kinetic selectivity for $\mathrm{C}-\mathrm{Br}$ abstraction is due to polar effects overriding thermodynamic effects. 
Figure S12 shows calculated distortion energies of substrates along the minimum energy reaction paths, represented by reaction trajectories obtained through Intrinsic Reaction Coordinate (IRC) calculations. The distortion energy of the substrate was calculated as the difference between the single-pint electronic energies of substrate ground-state geometry and distorted geometry in the IRC snapshot. In the fluorine atom abstraction from NFSI, the N-F bond lengthens abruptly near the TS. This is accompanied by a steep rise in distortion energy of the NFSI substrate immediately prior to the TS. In contrast, $\mathrm{C}-\mathrm{Br}$ lengthening in the bromine atom abstraction occurs slowly and gradually, and the distortion energy of the alkyl bromide substrate does not significantly increase at the TS. At the TS, the NFSI is $5.1 \mathrm{kcal} / \mathrm{mol}$ more distorted from its ground state geometry than the alkyl bromide. Despite the forming Si-F bond being much stronger, the stabilization it affords at the very early TS is not sufficient to cancel out the destabilizing effect of the higher NFSI distortion energy.

\section{N-F Abstraction}
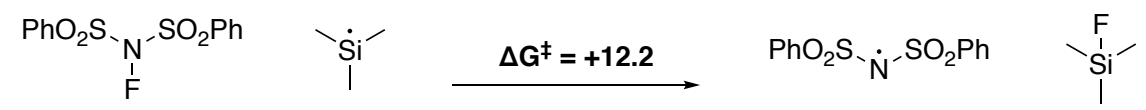

\section{C-Br Abstraction}
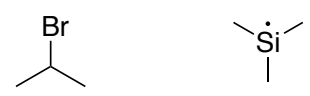

$\Delta \mathbf{G}^{\ddagger}=+9.3$
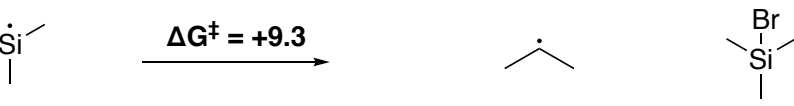

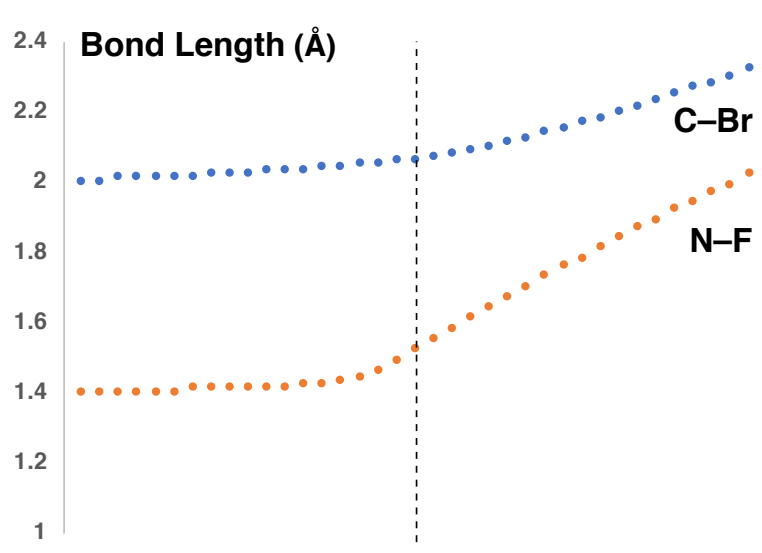

TS

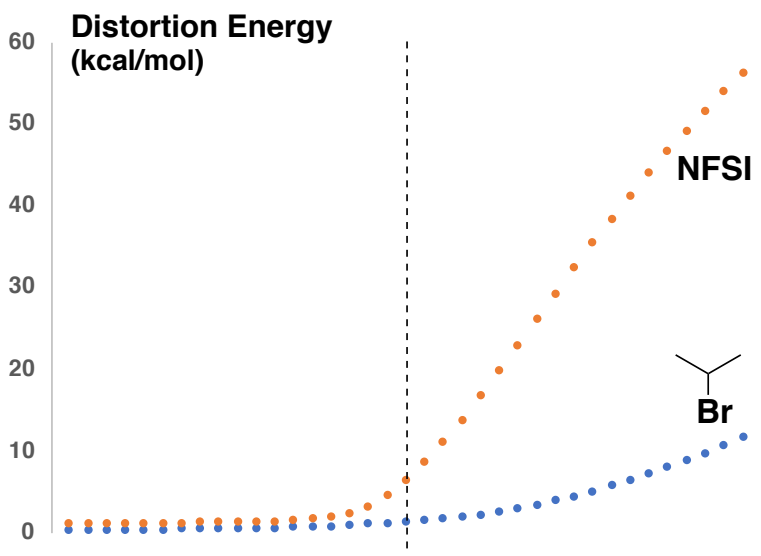

TS

Figure S12. Calculated bond lengths and distortion energies of substrates along the IRCs of halogen atom transfer with TMS radical as the abstractor. 


\section{Identity of Possible Silyl Radical Species Involved in Radical Chain Reaction}

With supersilanol as the precursor, either silyl radical species $\mathbf{3 2}$ or $\mathbf{3 4}$ can be envisioned to be responsible for bromine abstraction (Scheme S1). Both can be generated via intermediate radical 33.

The hydrogen atom transfer (HAT) between supersilanol and nitrogen radical $\mathbf{5}$ to furnish 33 was found to be exergonic by $5.3 \mathrm{kcal} / \mathrm{mol}$ and barrierless on the potential energy surface (PES). However, because supersilanol is acidic enough to be deprotonated by $\mathrm{K}_{3} \mathrm{PO}_{4}$, a deprotonation/SET or SET/deprotonation pathway also cannot be ruled out.
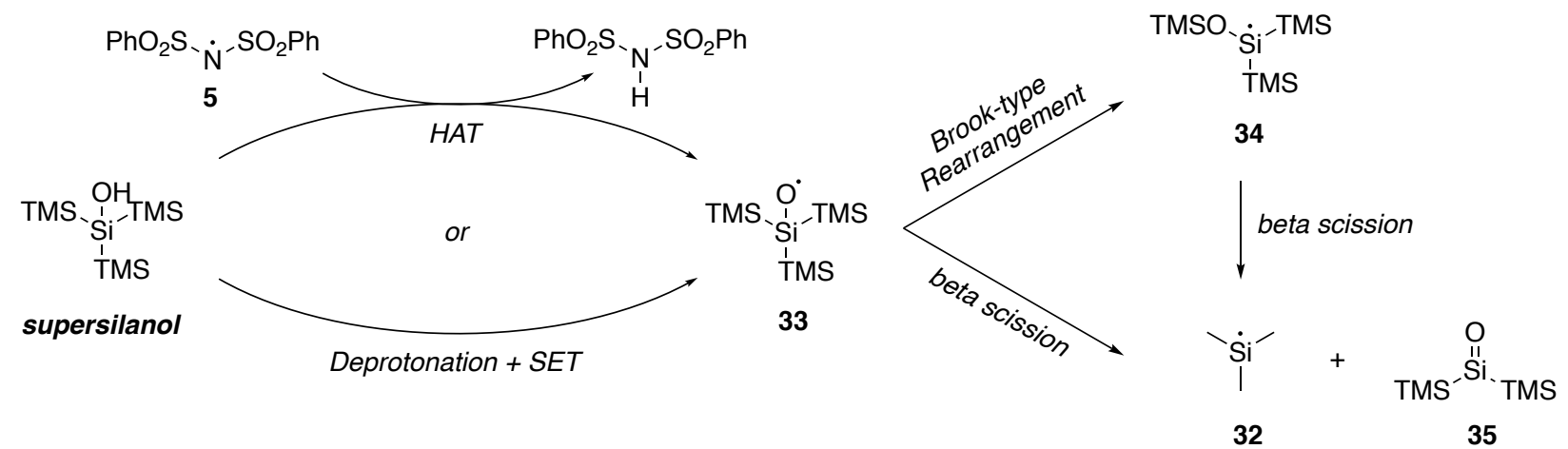

Scheme S1. Generation of possible active silyl radical species from supersilanol.

The radical Brook-type rearrangement of 33 (Figure S13, TS-E) leading to silyl radical 34 was found to be essentially barrierless with a $\Delta \mathrm{G}^{\ddagger}$ value of $0.2 \mathrm{kcal} / \mathrm{mol}$ in gas phase, and 1.1 $\mathrm{kcal} / \mathrm{mol}$ in implicit MeCN solvent (a transition state search in implicit water was not successful). When performing the TS search for the beta scission of 33, we were instead only able to locate TSs for the beta scission of rearranged radical 34 (TS-F), presumably due to the remarkable ease with which $\mathbf{3 3}$ undergoes the Brook-type rearrangement. The beta scission of $\mathbf{3 4}$ was found to have prohibitive free energy barriers of 62.1-71.2 kcal/mol (Figure S13). We therefore concluded that silyl radical $\mathbf{3 4}$ is the most likely active species in the bromine abstraction step. 


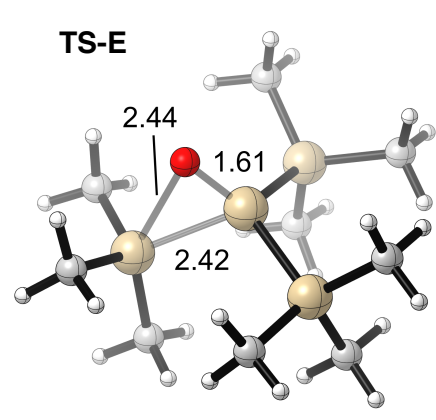

Brook-type Rearrangement TS

$$
\Delta G^{\ddagger}=+0.2 \text { (gas phase) }
$$
$+1.1(\mathrm{MeCN})$

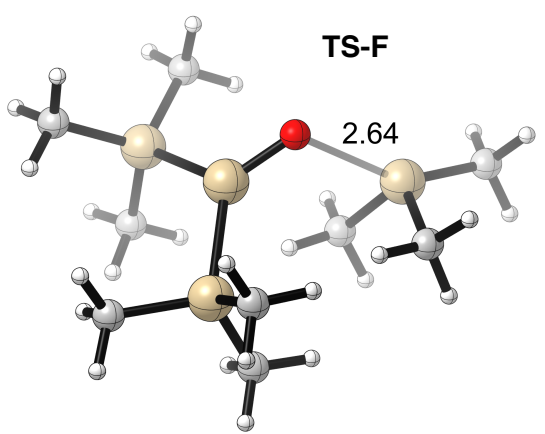

Beta Scission TS

$$
\begin{aligned}
\Delta \mathbf{G}^{\ddagger}= & +71.2 \text { (gas phase) } \\
& +66.1 \text { (MeCN) } \\
& +62.1 \text { (water) }
\end{aligned}
$$

Figure S13. Computed transition states of the Brook-type rearrangement from $\mathbf{3 3}$ and the beta scission of 34 at the M06-2X/6-311++G(d,p), SMD // M06-2X/6-31G(d), SMD level of theory. Geometries shown are optimized in gas phase. Free energies of activation are given in $\mathrm{kcal} / \mathrm{mol}$.

\section{Feasibility of Energy Transfer to NFSI}

To investigate the possibility of triplet-triplet energy transfer between benzophenone and NFSI, we calculated the singlet and triplet structures of NFSI (Figure S14). The singlet-triplet energy gap for NFSI was found to be large at $>80 \mathrm{kcal} / \mathrm{mol}$, which makes triplet-triplet energy transfer unlikely between NFSI and benzophenone.

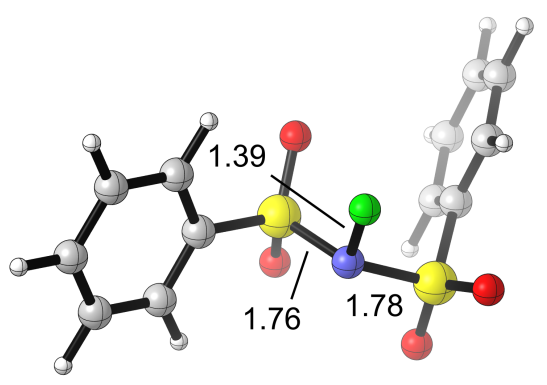

NFSI (singlet)

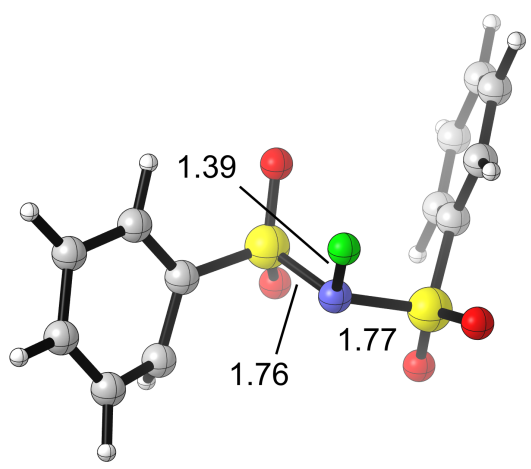

NFSI (triplet)

$\Delta \mathrm{G}=+\mathbf{8 8 . 0}$ (gas phase)

$+86.1(\mathrm{MeCN})$

+85.4 (water)

Figure S14. Computed structures of NFSI in the singlet and triplet states. at the M06-2X/6$311++\mathrm{G}(\mathrm{d}, \mathrm{p})$, SMD // M06-2X/6-31G(d), SMD level of theory. Geometries shown are optimized in gas phase. Free energies are given in $\mathrm{kcal} / \mathrm{mol}$. 


\section{Cartesian Coordinates and Energies of Calculated Structures}

$\begin{array}{lrrr} & & & \\ \text { (gas) } & & & \\ \mathrm{C} & & & \\ \mathrm{C} & -1.54505800 & -1.26688500 & -0.12826600 \\ \mathrm{C} & -0.91673800 & 0.00000000 & 0.42195000 \\ \mathrm{H} & -1.54505800 & 1.26688500 & -0.12826600 \\ \mathrm{H} & -1.05998100 & -2.15875200 & 0.27360100 \\ \mathrm{H} & -0.92564200 & 0.00000000 & 1.51280500 \\ \mathrm{H} & -1.05998000 & 2.15875200 & 0.27359900 \\ \mathrm{H} & -1.46464900 & 1.28931500 & -1.21890300 \\ \mathrm{H} & -1.46464700 & -1.28931600 & -1.21890300 \\ \mathrm{H} & -2.60700900 & -1.29309700 & 0.14233300 \\ \mathrm{Br} & -2.60700800 & 1.29309800 & 0.14233500 \\ & 1.00657200 & 0.00000000 & -0.02569700\end{array}$

$E[\mathrm{M} 06-2 \mathrm{X} / 6-311++\mathrm{G}(\mathrm{d}, \mathrm{p})]=-2692.67997410$ Hartrees $\Delta G[\mathrm{M} 06-2 \mathrm{X} / 6-31 \mathrm{G}(\mathrm{d})]=0.066367$ Hartrees

$\begin{array}{lrrr}(\mathrm{MeCN}) & & & \\ \mathrm{C} & 1.55056200 & 1.26611800 & -0.12928000 \\ \mathrm{C} & 0.92640300 & 0.00000000 & 0.42125800 \\ \mathrm{C} & 1.55056200 & -1.26611800 & -0.12928000 \\ \mathrm{H} & 1.07154100 & 2.16092900 & 0.27549800 \\ \mathrm{H} & 0.93155400 & 0.00000000 & 1.51169300 \\ \mathrm{H} & 1.07154100 & -2.16092900 & 0.27549800 \\ \mathrm{H} & 1.47987900 & -1.29189100 & -1.22118100 \\ \mathrm{H} & 1.47987900 & 1.29189100 & -1.22118100 \\ \mathrm{H} & 2.61067200 & 1.28447400 & 0.14851000 \\ \mathrm{H} & 2.61067200 & -1.28447400 & 0.14851000 \\ \mathrm{Br} & -1.01202500 & 0.00000000 & -0.02553000\end{array}$

$E[\mathrm{M} 06-2 \mathrm{X} / 6-311++\mathrm{G}(\mathrm{d}, \mathrm{p})]=-2692.68818894$ Hartrees $\Delta G[\mathrm{M} 06-2 \mathrm{X} / 6-31 \mathrm{G}(\mathrm{d})]=0.065997$ Hartrees

$\begin{array}{lrrr}\text { (water) } & & & \\ \mathrm{C} & 1.55012300 & 1.26498500 & -0.12929300 \\ \mathrm{C} & 0.92558300 & 0.00000000 & 0.42191200 \\ \mathrm{C} & 1.55012300 & -1.26498500 & -0.12929300 \\ \mathrm{H} & 1.07244500 & 2.16025100 & 0.27494000 \\ \mathrm{H} & 0.93126500 & 0.00000000 & 1.51201200 \\ \mathrm{H} & 1.07244500 & -2.16025100 & 0.27494000 \\ \mathrm{H} & 1.47768000 & -1.28938900 & -1.22081300 \\ \mathrm{H} & 1.47768000 & 1.28939000 & -1.22081300 \\ \mathrm{H} & 2.61032400 & 1.28160900 & 0.14700400 \\ \mathrm{H} & 2.61032400 & -1.28160900 & 0.14700400 \\ \mathrm{Br} & -1.01163300 & 0.00000000 & -0.02555000\end{array}$

$E[\mathrm{M} 06-2 \mathrm{X} / 6-311++\mathrm{G}(\mathrm{d}, \mathrm{p})]=-2692.68228245$ Hartrees $\Delta G[\mathrm{M} 06-2 \mathrm{X} / 6-31 \mathrm{G}(\mathrm{d})]=0.065895$ Hartrees 


$\begin{array}{lrrr} & & & \\ \text { (gas) } & & & \\ \mathrm{C} & & & \\ \mathrm{C} & 1.26750300 & -0.63838200 & -0.09661800 \\ \mathrm{C} & 0.00000000 & 0.04834100 & 0.37228400 \\ \mathrm{H} & -1.26750200 & -0.63838400 & -0.09661700 \\ \mathrm{H} & 2.14626200 & -0.06968800 & 0.21749800 \\ \mathrm{H} & 0.00000100 & 0.13748500 & 1.46611900 \\ \mathrm{H} & -2.14626400 & -0.06969900 & 0.21750800 \\ \mathrm{H} & -1.27059500 & -0.70740000 & -1.18874500 \\ \mathrm{~F} & 1.27059300 & -0.70741100 & -1.18874400 \\ \mathrm{H} & -0.00000200 & 1.34267500 & -0.13695700 \\ \mathrm{H} & 1.33684900 & -1.64840200 & 0.31735100 \\ & -1.33683900 & -1.64840900 & 0.31733900\end{array}$

$E[\mathrm{M} 06-2 \mathrm{X} / 6-311++\mathrm{G}(\mathrm{d}, \mathrm{p})]=-218.347526867$ Hartrees $\Delta G[\mathrm{M} 06-2 \mathrm{X} / 6-31 \mathrm{G}(\mathrm{d})]=0.070515$ Hartrees

$\begin{array}{lrcc}(\mathrm{MeCN}) & & & \\ \mathrm{C} & 1.26680300 & -0.63859800 & -0.09815600 \\ \mathrm{C} & 0.00000000 & 0.04111600 & 0.37390900 \\ \mathrm{C} & -1.26680300 & -0.63860000 & -0.09815600 \\ \mathrm{H} & 2.14804700 & -0.07546600 & 0.22277200 \\ \mathrm{H} & 0.00000000 & 0.13610500 & 1.46546000 \\ \mathrm{H} & -2.14804700 & -0.07546900 & 0.22277400 \\ \mathrm{H} & -1.27249800 & -0.70898700 & -1.19092800 \\ \mathrm{H} & 1.27249800 & -0.70898900 & -1.19092800 \\ \mathrm{~F} & -0.00000100 & 1.34967700 & -0.13634700 \\ \mathrm{H} & 1.33119000 & -1.64889600 & 0.31619800 \\ \mathrm{H} & -1.33118600 & -1.64889800 & 0.31619600\end{array}$

$E[\mathrm{M} 06-2 \mathrm{X} / 6-311++\mathrm{G}(\mathrm{d}, \mathrm{p})]=-218.354991790$ Hartrees $\Delta G[\mathrm{M} 06-2 \mathrm{X} / 6-31 \mathrm{G}(\mathrm{d})]=0.069956$ Hartrees

$\begin{array}{lrcc}\text { (water) } & & & \\ \mathrm{C} & 1.26558200 & -0.63862300 & -0.09818100 \\ \mathrm{C} & 0.00000000 & 0.04126700 & 0.37478600 \\ \mathrm{C} & -1.26558200 & -0.63862300 & -0.09818100 \\ \mathrm{H} & 2.14725700 & -0.07602200 & 0.22100500 \\ \mathrm{H} & 0.00000000 & 0.13635200 & 1.46598400 \\ \mathrm{H} & -2.14725700 & -0.07602300 & 0.22100700 \\ \mathrm{H} & -1.26882100 & -0.70962600 & -1.19063700 \\ \mathrm{H} & 1.26882000 & -0.70962800 & -1.19063700 \\ \mathrm{~F} & 0.00000000 & 1.34980800 & -0.13658700 \\ \mathrm{H} & 1.32991600 & -1.64872400 & 0.31600700 \\ \mathrm{H} & -1.32991500 & -1.64872400 & 0.31600600\end{array}$

$E[\mathrm{M} 06-2 \mathrm{X} / 6-311++\mathrm{G}(\mathrm{d}, \mathrm{p})]=-218.349817504$ Hartrees $\Delta G[\mathrm{M} 06-2 \mathrm{X} / 6-31 \mathrm{G}(\mathrm{d})]=0.070126$ Hartrees

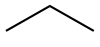
(gas)
$\mathrm{C}$
$\begin{array}{lll}-1.26658700 & -0.26087900 & 0.00000000\end{array}$ 


$\begin{array}{lrrr}\mathrm{C} & 0.00000000 & 0.59159800 & -0.00000100 \\ \mathrm{C} & 1.26658700 & -0.26087900 & 0.00000000 \\ \mathrm{H} & -2.16969800 & 0.35628100 & 0.00004000 \\ \mathrm{H} & 0.00000000 & 1.24868500 & -0.87750100 \\ \mathrm{H} & 2.16969800 & 0.35628100 & 0.00004000 \\ \mathrm{H} & 1.30011800 & -0.90726800 & 0.88357900 \\ \mathrm{H} & -1.30011800 & -0.90726800 & 0.88357900 \\ \mathrm{H} & -1.30016000 & -0.90721600 & -0.88361600 \\ \mathrm{H} & 1.30016000 & -0.90721600 & -0.88361600 \\ \mathrm{H} & 0.00000000 & 1.24868300 & 0.87750300\end{array}$

$E[\mathrm{M} 06-2 \mathrm{X} / 6-311++\mathrm{G}(\mathrm{d}, \mathrm{p})]=-119.100650412$ Hartrees $\Delta G[\mathrm{M} 06-2 \mathrm{X} / 6-31 \mathrm{G}(\mathrm{d})]=0.079646$ Hartrees

$\begin{array}{lrrr}(\mathrm{MeCN}) & & & \\ \mathrm{C} & 0.00000000 & -0.26103000 & 1.26534200 \\ \mathrm{C} & 0.00000000 & 0.59210700 & 0.00000000 \\ \mathrm{C} & 0.00000000 & -0.26103000 & -1.26534200 \\ \mathrm{H} & 0.00001000 & 0.35615600 & 2.16953500 \\ \mathrm{H} & -0.87872800 & 1.24842300 & 0.00000000 \\ \mathrm{H} & 0.00001000 & 0.35615600 & -2.16953500 \\ \mathrm{H} & 0.88453600 & -0.90736800 & -1.29944800 \\ \mathrm{H} & 0.88453600 & -0.90736800 & 1.29944800 \\ \mathrm{H} & -0.88454500 & -0.90735400 & 1.29945800 \\ \mathrm{H} & -0.88454500 & -0.90735400 & -1.29945800 \\ \mathrm{H} & 0.87872600 & 1.24842600 & 0.00000000\end{array}$

$E[\mathrm{M} 06-2 \mathrm{X} / 6-311++\mathrm{G}(\mathrm{d}, \mathrm{p})]=-119.103280805$ Hartrees $\Delta G[\mathrm{M} 06-2 \mathrm{X} / 6-31 \mathrm{G}(\mathrm{d})]=0.078888$ Hartrees

$\begin{array}{lrrr}\text { (water) } & & & \\ \mathrm{C} & 0.00000000 & -0.26102400 & 1.26443300 \\ \mathrm{C} & 0.00000000 & 0.59219700 & 0.00000000 \\ \mathrm{C} & 0.00000000 & -0.26102400 & -1.26443300 \\ \mathrm{H} & 0.00000600 & 0.35564900 & 2.16856100 \\ \mathrm{H} & -0.87858200 & 1.24814800 & 0.00000000 \\ \mathrm{H} & 0.00000600 & 0.35564900 & -2.16856100 \\ \mathrm{H} & 0.88439100 & -0.90712800 & -1.29785700 \\ \mathrm{H} & 0.88439100 & -0.90712800 & 1.29785700 \\ \mathrm{H} & -0.88439600 & -0.90712000 & 1.29786300 \\ \mathrm{H} & -0.88439600 & -0.90712000 & -1.29786300 \\ \mathrm{H} & 0.87857900 & 1.24815300 & 0.00000000\end{array}$

$E[\mathrm{M} 06-2 \mathrm{X} / 6-311++\mathrm{G}(\mathrm{d}, \mathrm{p})]=-119.098088603$ Hartrees $\Delta G[\mathrm{M} 06-2 \mathrm{X} / 6-31 \mathrm{G}(\mathrm{d})]=0.079312$ Hartrees

$\begin{array}{lrrr}\text { (gas) } & & & \\ \mathrm{C} & & & \\ \mathrm{C} & 1.29108100 & -0.19995400 & 0.00578600 \\ \mathrm{C} & 0.00000000 & 0.54193600 & -0.06631200 \\ \mathrm{H} & -1.29108100 & -0.19995500 & 0.00578500 \\ \mathrm{H} & 2.14212800 & 0.43120700 & -0.26473300 \\ \mathrm{H} & -0.00000200 & 1.60535100 & 0.15045200 \\ & -2.14211700 & 0.43117600 & -0.26483900\end{array}$




\begin{tabular}{lrrr}
$\mathrm{H}$ & -1.28451800 & -1.06882900 & -0.66425600 \\
$\mathrm{H}$ & 1.28456000 & -1.06876500 & -0.66433900 \\
$\mathrm{H}$ & 1.48643100 & -0.59119800 & 1.01806900 \\
$\mathrm{H}$ & -1.48648600 & -0.59110100 & 1.01809500 \\
\multicolumn{4}{c}{} \\
$E[\mathrm{M} 06-2 \mathrm{X} / 6-311++\mathrm{G}(\mathrm{d}, \mathrm{p})]=-118.435644837$ Hartree \\
$\Delta G[\mathrm{M} 06-2 \mathrm{X} / 6-31 \mathrm{G}(\mathrm{d})]=0.062371$ Hartrees \\
\multicolumn{4}{|}{} \\
$\mathrm{MeCN})$ & & & \\
$\mathrm{C}$ & 1.28903900 & -0.20024100 & 0.00583300 \\
$\mathrm{C}$ & 0.00000000 & 0.54454200 & -0.07038500 \\
$\mathrm{C}$ & -1.28903900 & -0.20024100 & 0.00583300 \\
$\mathrm{H}$ & 2.14705600 & 0.43599200 & -0.23169700 \\
$\mathrm{H}$ & -0.00000100 & 1.60657200 & 0.15738300 \\
$\mathrm{H}$ & -2.14705400 & 0.43598500 & -0.23172500 \\
$\mathrm{H}$ & -1.29516700 & -1.05485000 & -0.68357700 \\
$\mathrm{H}$ & 1.29517900 & -1.05483200 & -0.68359900 \\
$\mathrm{H}$ & 1.46259500 & -0.61662800 & 1.01276100 \\
$\mathrm{H}$ & -1.46261000 & -0.61660200 & 1.01276900
\end{tabular}

$E[\mathrm{M} 06-2 \mathrm{X} / 6-311++\mathrm{G}(\mathrm{d}, \mathrm{p})]=-118.438738728$ Hartrees $\Delta G[\mathrm{M} 06-2 \mathrm{X} / 6-31 \mathrm{G}(\mathrm{d})]=0.061803$ Hartrees

$\begin{array}{lrrr}\text { (water) } & & & \\ \mathrm{C} & 1.28856200 & -0.20025800 & 0.00586100 \\ \mathrm{C} & 0.00000000 & 0.54489400 & -0.07072800 \\ \mathrm{C} & -1.28856200 & -0.20025800 & 0.00586100 \\ \mathrm{H} & 2.14681300 & 0.43553200 & -0.23051900 \\ \mathrm{H} & 0.00000000 & 1.60636900 & 0.15835300 \\ \mathrm{H} & -2.14681300 & 0.43553100 & -0.23052300 \\ \mathrm{H} & -1.29445400 & -1.05430200 & -0.68380800 \\ \mathrm{H} & 1.29445600 & -1.05429900 & -0.68381100 \\ \mathrm{H} & 1.46092400 & -0.61755200 & 1.01217500 \\ \mathrm{H} & -1.46092600 & -0.61754900 & 1.01217600\end{array}$

$E[\mathrm{M} 06-2 \mathrm{X} / 6-311++\mathrm{G}(\mathrm{d}, \mathrm{p})]=-118.433545436$ Hartrees $\Delta G[\mathrm{M} 06-2 \mathrm{X} / 6-31 \mathrm{G}(\mathrm{d})]=0.062238$ Hartrees<smiles>O=S(Oc1ccccc1)N(F)S(=O)(=O)Oc1ccccc1</smiles>

\begin{tabular}{|c|c|c|c|}
\hline \multicolumn{4}{|c|}{ (gas) } \\
\hline $\mathrm{C}$ & 2.43367600 & 0.22478700 & -0.02938900 \\
\hline $\mathrm{C}$ & 2.73031300 & -0.26540900 & 1.23912700 \\
\hline $\mathrm{H}$ & 2.35883000 & 0.24923100 & 2.11926700 \\
\hline $\mathrm{C}$ & 3.49345200 & -1.42421400 & 1.33096000 \\
\hline $\mathrm{H}$ & 3.74266800 & -1.82795100 & 2.30656600 \\
\hline $\mathrm{C}$ & 3.92992500 & -2.06606300 & 0.17397500 \\
\hline $\mathrm{H}$ & 4.52007000 & -2.97383900 & 0.25339600 \\
\hline $\mathrm{C}$ & 3.61690400 & -1.55780300 & -1.0858890 \\
\hline $\mathrm{H}$ & 3.96284400 & -2.06542200 & -1.98015600 \\
\hline $\mathrm{C}$ & 2.85872400 & -0.39897500 & -1.1994580 \\
\hline $\mathrm{H}$ & 2.60201800 & 0.02341500 & -2.1653800 \\
\hline $\mathrm{C}$ & -2.44600100 & -0.39941000 & 0.205160 \\
\hline
\end{tabular}




$\begin{array}{lrrr}\mathrm{C} & -2.95851700 & -1.18546300 & -0.82159900 \\ \mathrm{H} & -2.29479000 & -1.81202900 & -1.40807300 \\ \mathrm{C} & -4.32929200 & -1.14757100 & -1.05614500 \\ \mathrm{H} & -4.75729400 & -1.75204300 & -1.84891300 \\ \mathrm{C} & -5.14922300 & -0.33846200 & -0.27181900 \\ \mathrm{H} & -6.21806800 & -0.31526600 & -0.45998700 \\ \mathrm{C} & -4.61277800 & 0.43989300 & 0.75333100 \\ \mathrm{H} & -5.25957200 & 1.06377900 & 1.36097100 \\ \mathrm{C} & -3.24513200 & 0.41743500 & 1.00041500 \\ \mathrm{H} & -2.79735000 & 1.00889600 & 1.79274900 \\ \mathrm{~N} & -0.23245100 & 0.97259300 & -0.44758400 \\ \mathrm{O} & 1.26928400 & 2.30261500 & 1.10980500 \\ \mathrm{O} & 1.67066100 & 2.33668200 & -1.40020200 \\ \mathrm{O} & -0.13828200 & -1.62055000 & -0.08282900 \\ \mathrm{O} & -0.42513800 & -0.02991200 & 1.87510000 \\ \mathrm{~F} & -0.23232900 & 0.49940000 & -1.75694300 \\ \mathrm{~S} & 1.38877200 & 1.64125600 & -0.16652900 \\ \mathrm{~S} & -0.70663100 & -0.42904900 & 0.51203800\end{array}$

$E[\mathrm{M} 06-2 \mathrm{X} / 6-311++\mathrm{G}(\mathrm{d}, \mathrm{p})]=-1714.82148797$ Hartrees $\Delta G[\mathrm{M} 06-2 \mathrm{X} / 6-31 \mathrm{G}(\mathrm{d})]=0.164320$ Hartrees

$\begin{array}{lrrr}(\mathrm{MeCN}) & & & \\ \mathrm{C} & 2.45003700 & 0.21291700 & -0.08618600 \\ \mathrm{C} & 2.80788600 & -0.18567900 & 1.20026500 \\ \mathrm{H} & 2.48789400 & 0.38580100 & 2.06582600 \\ \mathrm{C} & 3.58751300 & -1.32943800 & 1.33623600 \\ \mathrm{H} & 3.88912700 & -1.65959700 & 2.32467800 \\ \mathrm{C} & 3.97801700 & -2.04734700 & 0.20610600 \\ \mathrm{H} & 4.58187200 & -2.94231600 & 0.32110800 \\ \mathrm{C} & 3.60507900 & -1.62857000 & -1.07141500 \\ \mathrm{H} & 3.91714600 & -2.19187700 & -1.94459300 \\ \mathrm{C} & 2.83035500 & -0.48548900 & -1.23146900 \\ \mathrm{H} & 2.53403300 & -0.14100300 & -2.21700000 \\ \mathrm{C} & -2.46310000 & -0.37924000 & 0.25428700 \\ \mathrm{C} & -2.90626900 & -1.30551700 & -0.68701900 \\ \mathrm{H} & -2.21111300 & -1.99773200 & -1.15077400 \\ \mathrm{C} & -4.26092600 & -1.31787400 & -1.00401400 \\ \mathrm{H} & -4.63616000 & -2.02981100 & -1.73145500 \\ \mathrm{C} & -5.13052700 & -0.41975600 & -0.38672100 \\ \mathrm{H} & -6.18619500 & -0.43601200 & -0.63926100 \\ \mathrm{C} & -4.66158600 & 0.50001700 & 0.55238000 \\ \mathrm{H} & -5.34744300 & 1.19303400 & 1.02818800 \\ \mathrm{C} & -3.31142600 & 0.53127400 & 0.88190000 \\ \mathrm{H} & -2.92525700 & 1.23753800 & 1.61010600 \\ \mathrm{~N} & -0.23625400 & 0.93554900 & -0.46196000 \\ \mathrm{O} & 1.30303100 & 2.36320600 & 0.95706900 \\ \mathrm{O} & 1.62352500 & 2.24332600 & -1.55126900 \\ \mathrm{O} & -0.12054700 & -1.58448600 & 0.25960500 \\ \mathrm{O} & -0.52215000 & 0.24431500 & 1.96156500 \\ \mathrm{~F} & -0.23801400 & 0.30604700 & -1.70619400 \\ \mathrm{~S} & 1.39104300 & 1.60667200 & -0.27228200 \\ \mathrm{~S} & -0.74911800 & -0.33942000 & 0.65483000 \\ & & & \\ E[\mathrm{M} 06-2 \mathrm{X} / 6-311++\mathrm{G}(\mathrm{d}, \mathrm{p})] & -1714.84932261 \mathrm{Hartrees} \\ \Delta G[\mathrm{M} 06-2 \mathrm{X} / 6-31 \mathrm{G}(\mathrm{d})]=0.165366 & 0 & & \\ & & & \end{array}$




$\begin{array}{lrrr}\text { (water) } & & & \\ \mathrm{C} & 2.44896800 & 0.21006900 & -0.08164100 \\ \mathrm{C} & 2.79152600 & -0.20040600 & 1.20574500 \\ \mathrm{H} & 2.48146400 & 0.37173900 & 2.07417300 \\ \mathrm{C} & 3.54663100 & -1.36030300 & 1.33859800 \\ \mathrm{H} & 3.83672200 & -1.70095700 & 2.32649300 \\ \mathrm{C} & 3.92850900 & -2.07947300 & 0.20645800 \\ \mathrm{H} & 4.51331900 & -2.98673000 & 0.31989900 \\ \mathrm{C} & 3.57024900 & -1.64809300 & -1.07084200 \\ \mathrm{H} & 3.87512000 & -2.21321600 & -1.94486200 \\ \mathrm{C} & 2.81863500 & -0.48999300 & -1.22992700 \\ \mathrm{H} & 2.53269800 & -0.13751900 & -2.21549000 \\ \mathrm{C} & -2.45593600 & -0.37634100 & 0.24993900 \\ \mathrm{C} & -2.90151000 & -1.31957100 & -0.67350800 \\ \mathrm{H} & -2.20983700 & -2.01959700 & -1.13004500 \\ \mathrm{C} & -4.25780800 & -1.33756800 & -0.98116100 \\ \mathrm{H} & -4.63697900 & -2.06210400 & -1.69339300 \\ \mathrm{C} & -5.12370400 & -0.42841200 & -0.37522500 \\ \mathrm{H} & -6.18051300 & -0.44967400 & -0.62113300 \\ \mathrm{C} & -4.65051400 & 0.50906400 & 0.54388700 \\ \mathrm{H} & -5.33350200 & 1.21108100 & 1.00951600 \\ \mathrm{C} & -3.29954000 & 0.54699300 & 0.86620100 \\ \mathrm{H} & -2.91121900 & 1.26731200 & 1.57904400 \\ \mathrm{~N} & -0.23069700 & 0.95418200 & -0.46826600 \\ \mathrm{O} & 1.30575800 & 2.36141000 & 0.96849000 \\ \mathrm{O} & 1.64127700 & 2.25983200 & -1.53697900 \\ \mathrm{O} & -0.10293100 & -1.56759100 & 0.24283700 \\ \mathrm{O} & -0.50797000 & 0.25070100 & 1.95064600 \\ \mathrm{~F} & -0.22726800 & 0.32971500 & -1.71322400 \\ \mathrm{~S} & 1.40166700 & 1.60758800 & -0.26505200 \\ \mathrm{~S} & -0.74473500 & -0.32744100 & 0.64015100\end{array}$

$E[\mathrm{M} 06-2 \mathrm{X} / 6-311++\mathrm{G}(\mathrm{d}, \mathrm{p})]=-1714.84476069$ Hartrees $\Delta G[\mathrm{M} 06-2 \mathrm{X} / 6-31 \mathrm{G}(\mathrm{d})]=0.165331$ Hartrees

$$
\mathrm{PhO}_{2} \mathrm{~S}_{-}-\mathrm{N}^{-} \mathrm{SO}_{2} \mathrm{Ph}
$$

$\begin{array}{lccc}\text { (gas) } & & & \\ \mathrm{N} & 0.31264300 & 1.18571100 & -0.00068200 \\ \mathrm{~S} & 0.71725000 & -0.46861900 & 0.00062400 \\ \mathrm{O} & 0.27032300 & -1.01425900 & 1.27125400 \\ \mathrm{O} & 0.26939600 & -1.01660800 & -1.26864800 \\ \mathrm{~S} & -1.34053800 & 1.66531600 & 0.00026400 \\ \mathrm{O} & -1.47837800 & 2.34645500 & 1.27174900 \\ \mathrm{O} & -1.47974900 & 2.34781100 & -1.27032300 \\ \mathrm{C} & -2.38792900 & 0.23973200 & 0.00000500 \\ \mathrm{C} & -2.79060500 & -0.29294800 & -1.22131000 \\ \mathrm{C} & -2.78663200 & -0.29634700 & 1.22113400 \\ \mathrm{C} & -3.62564900 & -1.40405200 & -1.21187600 \\ \mathrm{H} & -2.45300100 & 0.15907500 & -2.14774200 \\ \mathrm{C} & -3.62167500 & -1.40744900 & 1.21131000 \\ \mathrm{H} & -2.44588300 & 0.15295300 & 2.14773500 \\ \mathrm{C} & -4.03685200 & -1.95680200 & -0.00038300\end{array}$




$\begin{array}{lrrr}\mathrm{H} & -3.95539100 & -1.83768300 & -2.14997800 \\ \mathrm{H} & -3.94831100 & -1.84374200 & 2.14926600 \\ \mathrm{H} & -4.68740200 & -2.82586600 & -0.00053000 \\ \mathrm{C} & 2.48215200 & -0.36965600 & -0.00015200 \\ \mathrm{C} & 3.14926700 & -0.33262700 & 1.22027200 \\ \mathrm{C} & 3.14820800 & -0.33456400 & -1.22119200 \\ \mathrm{C} & 4.53756100 & -0.25083000 & 1.21021700 \\ \mathrm{H} & 2.58718300 & -0.37703500 & 2.14741200 \\ \mathrm{C} & 4.53651000 & -0.25274200 & -1.21246300 \\ \mathrm{H} & 2.58532400 & -0.38040000 & -2.14778100 \\ \mathrm{C} & 5.22510800 & -0.20954700 & -0.00145400 \\ \mathrm{H} & 5.08258200 & -0.22263000 & 2.14782700 \\ \mathrm{H} & 5.08073800 & -0.22600900 & -2.15057500 \\ \mathrm{H} & 6.30875300 & -0.14598800 & -0.00197700\end{array}$

$E[\mathrm{M} 06-2 \mathrm{X} / 6-311++\mathrm{G}(\mathrm{d}, \mathrm{p})]=-1614.99018719$ Hartrees $\Delta G[\mathrm{M} 06-2 \mathrm{X} / 6-31 \mathrm{G}(\mathrm{d})]=0.161297$ Hartrees

$\begin{array}{lrrr}(\mathrm{MeCN}) & & & \\ \mathrm{N} & 0.31231200 & 1.12412600 & -0.26911300 \\ \mathrm{~S} & 0.74112000 & -0.48493900 & 0.12282800 \\ \mathrm{O} & 0.32189800 & -0.71021500 & 1.49744300 \\ \mathrm{O} & 0.23596100 & -1.31376000 & -0.96009800 \\ \mathrm{~S} & -1.32581400 & 1.63614200 & -0.16215500 \\ \mathrm{O} & -1.33724800 & 2.38090100 & 1.08616000 \\ \mathrm{O} & -1.54329200 & 2.29804700 & -1.43609200 \\ \mathrm{C} & -2.40654900 & 0.24730400 & -0.04010300 \\ \mathrm{C} & -2.86228700 & -0.34410100 & -1.21748300 \\ \mathrm{C} & -2.77700700 & -0.20504100 & 1.22510900 \\ \mathrm{C} & -3.72125400 & -1.43203900 & -1.11532800 \\ \mathrm{H} & -2.55514700 & 0.04000900 & -2.18477700 \\ \mathrm{C} & -3.64015200 & -1.29292300 & 1.30560800 \\ \mathrm{H} & -2.40251000 & 0.28387100 & 2.11814200 \\ \mathrm{C} & -4.10680600 & -1.90216900 & 0.14058300 \\ \mathrm{H} & -4.09401100 & -1.90873800 & -2.01571800 \\ \mathrm{H} & -3.94897900 & -1.66194800 & 2.27768900 \\ \mathrm{H} & -4.78044300 & -2.75043100 & 0.21195400 \\ \mathrm{C} & 2.49763800 & -0.38372300 & 0.03972000 \\ \mathrm{C} & 3.20030600 & -0.05069200 & 1.19648700 \\ \mathrm{C} & 3.12212500 & -0.62986200 & -1.18076700 \\ \mathrm{C} & 4.58632800 & 0.03639000 & 1.11825600 \\ \mathrm{H} & 2.67748400 & 0.12873100 & 2.13030700 \\ \mathrm{C} & 4.50903700 & -0.53751300 & -1.23739900 \\ \mathrm{H} & 2.53996100 & -0.89164500 & -2.05860200 \\ \mathrm{C} & 5.23468200 & -0.20460400 & -0.09305100 \\ \mathrm{H} & 5.15868500 & 0.29135300 & 2.00377300 \\ \mathrm{H} & 5.02232000 & -0.73002400 & -2.17351300 \\ \mathrm{H} & 6.31664600 & -0.13524500 & -0.14531900\end{array}$

$E[\mathrm{M} 06-2 \mathrm{X} / 6-311++\mathrm{G}(\mathrm{d}, \mathrm{p})]=-1615.01712940$ Hartrees $\Delta G[\mathrm{M} 06-2 \mathrm{X} / 6-31 \mathrm{G}(\mathrm{d})]=0.160721$ Hartrees
(water)
$\mathrm{N} \quad-0.28445100 \quad 1.06220800 \quad-0.47184900$
S $\quad-0.73763800 \quad-0.44131900 \quad 0.22080600$
O $\quad-0.18874100 \quad-1.46069700 \quad-0.66308400$ 


$\begin{array}{lccc}\mathrm{O} & -0.35818900 & -0.40096800 & 1.62659200 \\ \mathrm{~S} & 1.33110100 & 1.62224900 & -0.25478300 \\ \mathrm{O} & 1.61884000 & 2.29808100 & -1.50827500 \\ \mathrm{O} & 1.23871400 & 2.37181900 & 0.99010300 \\ \mathrm{C} & 2.41284300 & 0.24775800 & -0.07108400 \\ \mathrm{C} & 2.75779800 & -0.16854700 & 1.21356100 \\ \mathrm{C} & 2.86867200 & -0.39041900 & -1.22499700 \\ \mathrm{C} & 3.59674800 & -1.27052500 & 1.33885900 \\ \mathrm{H} & 2.38437300 & 0.35640200 & 2.08606300 \\ \mathrm{C} & 3.70052300 & -1.49318300 & -1.07515600 \\ \mathrm{H} & 2.58078000 & -0.03440500 & -2.20878900 \\ \mathrm{C} & 4.06007600 & -1.92918800 & 0.20054100 \\ \mathrm{H} & 3.88810400 & -1.61268600 & 2.32574200 \\ \mathrm{H} & 4.06980400 & -2.00964300 & -1.95424100 \\ \mathrm{H} & 4.71099300 & -2.79076900 & 0.30787100 \\ \mathrm{C} & -2.48697200 & -0.37275400 & 0.06578000 \\ \mathrm{C} & -3.06572000 & -0.79934500 & -1.12832600 \\ \mathrm{C} & -3.22991000 & 0.11413500 & 1.13933500 \\ \mathrm{C} & -4.44958400 & -0.73279500 & -1.24226000 \\ \mathrm{H} & -2.45311500 & -1.17797000 & -1.94003000 \\ \mathrm{C} & -4.61275200 & 0.17092400 & 1.00311900 \\ \mathrm{H} & -2.74190600 & 0.43229000 & 2.05455000 \\ \mathrm{C} & -5.21615300 & -0.24900800 & -0.18168000 \\ \mathrm{H} & -4.92881900 & -1.06143000 & -2.15786100 \\ \mathrm{H} & -5.21707600 & 0.54108600 & 1.82395800 \\ \mathrm{H} & -6.29580400 & -0.20142000 & -0.27952000\end{array}$

$E[\mathrm{M} 06-2 \mathrm{X} / 6-311++\mathrm{G}(\mathrm{d}, \mathrm{p})]=-1615.01387377$ Hartrees $\Delta G[\mathrm{M} 06-2 \mathrm{X} / 6-31 \mathrm{G}(\mathrm{d})]=0.160561$ Hartrees

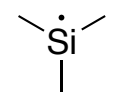

$\begin{array}{lrrr}\text { (gas) } & & & \\ \mathrm{Si} & -0.00011800 & -0.00024900 & -0.43695100 \\ \mathrm{C} & -1.68154100 & -0.60706200 & 0.18208500 \\ \mathrm{H} & -1.70460200 & -0.61856600 & 1.27890800 \\ \mathrm{H} & -2.49074700 & 0.04312200 & -0.16321500 \\ \mathrm{H} & -1.89225500 & -1.62173700 & -0.16842100 \\ \mathrm{C} & 1.36687900 & -1.15188500 & 0.18208100 \\ \mathrm{H} & 1.39019600 & -1.16415000 & 1.27889900 \\ \mathrm{H} & 1.20870800 & -2.17838400 & -0.16158700 \\ \mathrm{H} & 2.35017400 & -0.82679800 & -0.17037800 \\ \mathrm{C} & 0.31473300 & 1.75905100 & 0.18197500 \\ \mathrm{H} & -0.46138100 & 2.44767200 & -0.16483300 \\ \mathrm{H} & 0.32114500 & 1.78472000 & 1.27882600 \\ \mathrm{H} & 1.27998300 & 2.13698000 & -0.16773000\end{array}$

$E[\mathrm{M} 06-2 \mathrm{X} / 6-311++\mathrm{G}(\mathrm{d}, \mathrm{p})]=-409.158377747$ Hartrees $\Delta G[\mathrm{M} 06-2 \mathrm{X} / 6-31 \mathrm{G}(\mathrm{d})]=0.079915$ Hartrees

$\begin{array}{lccr}(\mathrm{MeCN}) & & & \\ \mathrm{Si} & 0.00013400 & 0.00007100 & -0.43264000 \\ \mathrm{C} & -0.83325800 & 1.58041300 & 0.17935900 \\ \mathrm{H} & -0.84889700 & 1.59878600 & 1.27729200\end{array}$




$\begin{array}{lrrr}H & -0.30009300 & 2.47367700 & -0.16252800 \\ \mathrm{H} & -1.86811800 & 1.65033700 & -0.17161900 \\ \mathrm{C} & -0.95244500 & -1.51173100 & 0.17936300 \\ \mathrm{H} & -0.96581500 & -1.53152100 & 1.27725800 \\ \mathrm{H} & -1.99075600 & -1.49917200 & -0.16827200 \\ \mathrm{H} & -0.49199200 & -2.44308600 & -0.16644700 \\ \mathrm{C} & 1.78546000 & -0.06880800 & 0.17935100 \\ \mathrm{H} & 2.36188500 & 0.79543700 & -0.16684100 \\ \mathrm{H} & 1.80955700 & -0.07017800 & 1.27729000 \\ \mathrm{H} & 2.29381600 & -0.97452300 & -0.16760700\end{array}$

$E[\mathrm{M} 06-2 \mathrm{X} / 6-311++\mathrm{G}(\mathrm{d}, \mathrm{p})]=-409.160741140$ Hartrees $\Delta G[\mathrm{M} 06-2 \mathrm{X} / 6-31 \mathrm{G}(\mathrm{d})]=0.079873$ Hartrees

$\begin{array}{lrrr}\text { (water) } & & & \\ \mathrm{Si} & -0.00041200 & 0.00017100 & -0.43196200 \\ \mathrm{C} & -1.74907100 & 0.36518700 & 0.17921300 \\ \mathrm{H} & -1.77377200 & 0.36704300 & 1.27670600 \\ \mathrm{H} & -2.09741700 & 1.34419800 & -0.16506400 \\ \mathrm{H} & -2.46192500 & -0.38847100 & -0.17021600 \\ \mathrm{C} & 0.55816700 & -1.69672000 & 0.17892100 \\ \mathrm{H} & 0.56332700 & -1.72051200 & 1.27646800 \\ \mathrm{H} & -0.11086800 & -2.48994000 & -0.16960000 \\ \mathrm{H} & 1.56995900 & -1.93334500 & -0.16551800 \\ \mathrm{C} & 1.19133300 & 1.33137900 & 0.17922200 \\ \mathrm{H} & 0.89340700 & 2.32613900 & -0.16709700 \\ \mathrm{H} & 1.20821900 & 1.34835500 & 1.27670800 \\ \mathrm{H} & 2.21226400 & 1.14506400 & -0.16905300\end{array}$

$E[\mathrm{M} 06-2 \mathrm{X} / 6-311++\mathrm{G}(\mathrm{d}, \mathrm{p})]=-409.154931291$ Hartrees $\Delta G[\mathrm{M} 06-2 \mathrm{X} / 6-31 \mathrm{G}(\mathrm{d})]=0.079617$ Hartrees<smiles>CO[Si](C)(Br)O[Si]</smiles>

$\begin{array}{lccc}\text { (gas) } & & & \\ \mathrm{Si} & 0.34551400 & 0.00020400 & 0.16563700 \\ \mathrm{Si} & -2.75022500 & -0.05064000 & 0.51608200 \\ \mathrm{Si} & 1.37199300 & 2.07231200 & 0.49641900 \\ \mathrm{Si} & 1.50637100 & -1.99308800 & 0.52030400 \\ \mathrm{O} & -1.12429700 & -0.09958600 & 0.92299400 \\ \mathrm{C} & 0.43784200 & 3.38563700 & -0.48232800 \\ \mathrm{H} & 0.98308900 & 4.33562700 & -0.48474400 \\ \mathrm{H} & 0.30697900 & 3.05804500 & -1.51874700 \\ \mathrm{H} & -0.55528200 & 3.56456200 & -0.05824900 \\ \mathrm{C} & 1.38588200 & 2.48301200 & 2.33943600 \\ \mathrm{H} & 1.94724000 & 1.73382400 & 2.90766000 \\ \mathrm{H} & 1.84706000 & 3.45951400 & 2.52234200 \\ \mathrm{H} & 0.36621100 & 2.50954000 & 2.73676600 \\ \mathrm{C} & 3.13651000 & 1.90060000 & -0.15615500 \\ \mathrm{H} & 3.13555200 & 1.55369700 & -1.19514600 \\ \mathrm{H} & 3.66323500 & 2.86053000 & -0.12194400 \\ \mathrm{H} & 3.71258800 & 1.18368500 & 0.43966300\end{array}$




$\begin{array}{lrrr}\mathrm{C} & 2.24479700 & -2.01034500 & 2.25897100 \\ \mathrm{H} & 2.74188900 & -2.96486100 & 2.46346000 \\ \mathrm{H} & 2.98938300 & -1.21548200 & 2.37754300 \\ \mathrm{H} & 1.47096900 & -1.86452300 & 3.01933000 \\ \mathrm{C} & 0.22673400 & -3.36454800 & 0.31855600 \\ \mathrm{H} & -0.23606900 & -3.30850800 & -0.67272500 \\ \mathrm{H} & 0.68000700 & -4.35548600 & 0.42864900 \\ \mathrm{C} & 2.86784500 & -2.15265000 & -0.77557700 \\ \mathrm{H} & 3.64450700 & -1.39386100 & -0.63430600 \\ \mathrm{H} & 3.34461800 & -3.13748800 & -0.72442000 \\ \mathrm{H} & 2.44986100 & -2.02234400 & -1.77883700 \\ \mathrm{C} & -3.15892800 & -1.52896600 & -0.56178500 \\ \mathrm{H} & -4.21487200 & -1.52423100 & -0.85379000 \\ \mathrm{H} & -2.55230100 & -1.51295700 & -1.47271700 \\ \mathrm{H} & -2.95812000 & -2.46880600 & -0.03663500 \\ \mathrm{C} & -3.69113900 & -0.12386000 & 2.13301300 \\ \mathrm{H} & -4.77265700 & -0.10091100 & 1.96174100 \\ \mathrm{H} & -3.45679600 & -1.04283200 & 2.67939300 \\ \mathrm{H} & -3.43341000 & 0.72388100 & 2.77564000 \\ \mathrm{H} & -0.56618400 & -3.26474600 & 1.06696700 \\ \mathrm{C} & -3.09251800 & 1.55240600 & -0.39405000 \\ \mathrm{H} & -2.46289700 & 1.62110600 & -1.28795700 \\ \mathrm{H} & -4.13931800 & 1.61507800 & -0.71061400 \\ \mathrm{H} & -2.88099300 & 2.41924800 & 0.24124100 \\ \mathrm{Br} & -0.02380600 & -0.02615300 & -2.09463400\end{array}$

$E[\mathrm{M} 06-2 \mathrm{X} / 6-311++\mathrm{G}(\mathrm{d}, \mathrm{p})]=-4166.70647210$ Hartrees $\Delta G[\mathrm{M} 06-2 \mathrm{X} / 6-31 \mathrm{G}(\mathrm{d})]=0.285855$ Hartrees

$\begin{array}{lrrr}(\mathrm{MeCN}) & & & \\ \mathrm{Si} & 0.34281900 & 0.00361300 & 0.17141600 \\ \mathrm{Si} & -2.75710400 & -0.11329100 & 0.51342400 \\ \mathrm{Si} & 1.29334400 & 2.11756500 & 0.47865500 \\ \mathrm{Si} & 1.58237500 & -1.94097500 & 0.54012900 \\ \mathrm{O} & -1.12840500 & -0.15198600 & 0.92162800 \\ \mathrm{C} & 0.37426500 & 3.38194100 & -0.57428900 \\ \mathrm{H} & 0.90310800 & 4.34233800 & -0.57239700 \\ \mathrm{H} & 0.29736800 & 3.03523100 & -1.61044500 \\ \mathrm{H} & -0.63984700 & 3.55404800 & -0.19798300 \\ \mathrm{C} & 1.21160800 & 2.57789800 & 2.30486000 \\ \mathrm{H} & 1.74142200 & 1.84461200 & 2.92308800 \\ \mathrm{H} & 1.66652600 & 3.55952100 & 2.48194600 \\ \mathrm{H} & 0.17304800 & 2.62142300 & 2.65145800 \\ \mathrm{C} & 3.08625400 & 1.96688200 & -0.08741300 \\ \mathrm{H} & 3.15046100 & 1.61642900 & -1.12373800 \\ \mathrm{H} & 3.59353900 & 2.93736200 & -0.02984300 \\ \mathrm{H} & 3.64221000 & 1.26423400 & 0.54419300 \\ \mathrm{C} & 2.22739400 & -1.96347100 & 2.31133400 \\ \mathrm{H} & 2.78410800 & -2.88694700 & 2.51028700 \\ \mathrm{H} & 2.90238400 & -1.12028300 & 2.49775200 \\ \mathrm{H} & 1.40683200 & -1.90499500 & 3.03491300 \\ \mathrm{C} & 0.39024700 & -3.37332000 & 0.25071400 \\ \mathrm{H} & -0.05993400 & -3.31525000 & -0.74677100 \\ \mathrm{H} & 0.90758500 & -4.33666000 & 0.33187000 \\ \mathrm{C} & 3.01663500 & -1.99438500 & -0.68025100 \\ \mathrm{H} & 3.73714600 & -1.19322500 & -0.48101600\end{array}$




$\begin{array}{lrrr}\mathrm{H} & 3.54881200 & -2.95054500 & -0.61196700 \\ \mathrm{H} & 2.65630300 & -1.87623700 & -1.70793800 \\ \mathrm{C} & -3.14787700 & -1.59759500 & -0.56032400 \\ \mathrm{H} & -4.20432700 & -1.59829200 & -0.85418200 \\ \mathrm{H} & -2.54197900 & -1.58487800 & -1.47268300 \\ \mathrm{H} & -2.94798600 & -2.53558200 & -0.03003300 \\ \mathrm{C} & -3.70009600 & -0.19235400 & 2.12649300 \\ \mathrm{H} & -4.78137700 & -0.17976900 & 1.94670600 \\ \mathrm{H} & -3.46396000 & -1.10892000 & 2.67836500 \\ \mathrm{H} & -3.45731200 & 0.66067900 & 2.76984400 \\ \mathrm{H} & -0.41730000 & -3.36195100 & 0.99085600 \\ \mathrm{C} & -3.11058700 & 1.48808500 & -0.39310600 \\ \mathrm{H} & -2.48079200 & 1.57306300 & -1.28601700 \\ \mathrm{H} & -4.15784800 & 1.53565800 & -0.71415700 \\ \mathrm{H} & -2.91726500 & 2.35553000 & 0.24836300 \\ \mathrm{Br} & -0.01602400 & -0.06941600 & -2.10235200\end{array}$

$E[\mathrm{M} 06-2 \mathrm{X} / 6-311++\mathrm{G}(\mathrm{d}, \mathrm{p})]=-4166.71506722$ Hartrees $\Delta G[\mathrm{M} 06-2 \mathrm{X} / 6-31 \mathrm{G}(\mathrm{d})]=0.287631$ Hartrees

\begin{tabular}{lrrr} 
(water) & & & \\
$\mathrm{Si}$ & 0.34294700 & 0.00440400 & 0.15934100 \\
$\mathrm{Si}$ & -2.73702400 & -0.15483700 & 0.52125000 \\
$\mathrm{Si}$ & 1.22575900 & 2.14849500 & 0.44949600 \\
$\mathrm{Si}$ & 1.64343400 & -1.88947300 & 0.55690100 \\
$\mathrm{O}$ & -1.10777500 & -0.24225200 & 0.93903400 \\
$\mathrm{C}$ & 0.36526300 & 3.38090900 & -0.68465700 \\
$\mathrm{H}$ & 0.91813800 & 4.32695700 & -0.71353200 \\
$\mathrm{H}$ & 0.30648100 & 2.98740100 & -1.70502300 \\
$\mathrm{H}$ & -0.65324300 & 3.59457400 & -0.34412800 \\
$\mathrm{C}$ & 1.04216100 & 2.64364500 & 2.25734000 \\
$\mathrm{H}$ & 1.53997700 & 1.92287600 & 2.91537600 \\
$\mathrm{H}$ & 1.48166600 & 3.63031400 & 2.44239500 \\
$\mathrm{H}$ & -0.01440900 & 2.68521700 & 2.54402900 \\
$\mathrm{C}$ & 3.04491700 & 1.96567200 & -0.01518300 \\
$\mathrm{H}$ & 3.15822900 & 1.58102700 & -1.03516300 \\
$\mathrm{H}$ & 3.56614900 & 2.92824500 & 0.04178500 \\
$\mathrm{H}$ & 3.55031300 & 1.27096600 & 0.66635700 \\
$\mathrm{C}$ & 2.29439000 & -1.85034600 & 2.32500400 \\
$\mathrm{H}$ & 2.86381600 & -2.75770200 & 2.55670900 \\
$\mathrm{H}$ & 2.95740600 & -0.99056100 & 2.47581400 \\
$\mathrm{H}$ & 1.47465400 & -1.77497900 & 3.04758200 \\
$\mathrm{C}$ & 0.44479300 & -3.32359000 & 0.30172900 \\
$\mathrm{H}$ & -0.01233600 & -3.27208400 & -0.69333800 \\
$\mathrm{H}$ & 0.94838300 & -4.29241900 & 0.39475000 \\
$\mathrm{C}$ & 3.06770200 & -1.94487800 & -0.67366500 \\
$\mathrm{H}$ & 3.78494600 & -1.13959200 & -0.48062700 \\
$\mathrm{H}$ & 3.60484500 & -2.89799000 & -0.60877400 \\
$\mathrm{H}$ & 2.69606200 & -1.82992500 & -1.69757900 \\
$\mathrm{C}$ & -3.14228500 & -1.61901000 & -0.57341500 \\
$\mathrm{H}$ & -4.20043600 & -1.61452600 & -0.85956400 \\
$\mathrm{H}$ & -2.54124900 & -1.59634000 & -1.48812600 \\
$\mathrm{H}$ & -2.93887300 & -2.56348800 & -0.05586800 \\
$\mathrm{C}$ & -3.68365300 & -0.24461300 & 2.13057700 \\
$\mathrm{H}$ & -4.76416800 & -0.22393600 & 1.94917800 \\
$\mathrm{H}$ & -3.45415000 & -1.16888900 & 2.67168100 \\
& & & \\
\hline
\end{tabular}




$\begin{array}{lrrr}\mathrm{H} & -3.43661200 & 0.59948800 & 2.78364800 \\ \mathrm{H} & -0.35869500 & -3.28655300 & 1.04563400 \\ \mathrm{C} & -3.03812800 & 1.47298700 & -0.35448000 \\ \mathrm{H} & -2.44036700 & 1.53755800 & -1.27080000 \\ \mathrm{H} & -4.09318200 & 1.58451100 & -0.62958500 \\ \mathrm{H} & -2.77079400 & 2.31736500 & 0.29149700 \\ \mathrm{Br} & -0.03808400 & -0.11498300 & -2.10439800\end{array}$

$E[\mathrm{M} 06-2 \mathrm{X} / 6-311++\mathrm{G}(\mathrm{d}, \mathrm{p})]=-4166.69970149$ Hartrees $\Delta G[\mathrm{M} 06-2 \mathrm{X} / 6-31 \mathrm{G}(\mathrm{d})]=0.288882$ Hartrees<smiles>CO[Si](F)([SiH3])[AsH3]</smiles>

(gas)

$\mathrm{Si}$

$\mathrm{Si}$

$\mathrm{Si}$

$\mathrm{Si}$

$\mathrm{O}$

$\mathrm{C}$

$\mathrm{H}$

$\mathrm{H}$

$\mathrm{H}$

$\mathrm{C}$

$\mathrm{H}$

$\mathrm{H}$

$\mathrm{H}$

$\mathrm{C}$

$\mathrm{H}$

$\mathrm{H}$

$\mathrm{H}$

C

$\mathrm{H}$

$\mathrm{H}$

$\mathrm{H}$

C

$\mathrm{H}$

$\mathrm{H}$

C

$\mathrm{H}$

$\mathrm{H}$

$\mathrm{H}$

C

$\mathrm{H}$

$\mathrm{H}$

$\mathrm{H}$

C

$\mathrm{H}$

$\mathrm{H}$

$\mathrm{H}$

$\mathrm{H}$

C

$$
\begin{array}{rrr}
-0.27716900 & -0.01092300 & -0.35843100 \\
2.75718900 & -0.09165000 & 0.13349200 \\
-1.53926600 & -1.92384600 & 0.10561400 \\
-1.33394000 & 2.02665800 & 0.09421900 \\
1.12908900 & -0.09872100 & 0.51474300 \\
-0.73893900 & -3.43758700 & -0.69226200 \\
-1.31968800 & -4.34220800 & -0.48091400 \\
-0.67032800 & -3.32263000 & -1.77849200 \\
0.27427200 & -3.59010700 & -0.30666000 \\
-1.60031200 & -2.15075200 & 1.98036600 \\
-2.09751800 & -1.30705600 & 2.47036200 \\
-2.15003100 & -3.06138800 & 2.24287300 \\
-0.59090000 & -2.23161800 & 2.39566800 \\
-3.29793900 & -1.69663000 & -0.55419700 \\
-3.30384900 & -1.54046500 & -1.63785000 \\
-3.90963200 & -2.57965100 & -0.33888900 \\
-3.78697200 & -0.83399600 & -0.08746200 \\
-2.26682900 & 1.82463500 & 1.72832300 \\
-2.74680800 & 2.76423300 & 2.02355600 \\
-3.05187100 & 1.06421400 & 1.64495000 \\
-1.59253700 & 1.52355700 & 2.53707200 \\
-0.04330600 & 3.39475500 & 0.27423400 \\
0.51068900 & 3.54698600 & -0.65764700 \\
-0.51557000 & 4.34502100 & 0.54657200 \\
-2.56565500 & 2.45130300 & -1.27369200 \\
-3.32403900 & 1.66824300 & -1.37924100 \\
-3.08351200 & 3.39107700 & -1.05280300 \\
-2.06261300 & 2.56137200 & -2.23934600 \\
3.16734800 & 1.51192300 & -0.74833100 \\
4.22297400 & 1.54745900 & -1.03884700 \\
2.56558800 & 1.60890500 & -1.65904300 \\
2.96313000 & 2.38006200 & -0.11308900 \\
3.68616000 & -0.23095300 & 1.75241100 \\
4.76898100 & -0.24044900 & 1.58899900 \\
3.45165100 & 0.61123700 & 2.41109000 \\
3.41673100 & -1.15258800 & 2.27780100 \\
0.67845700 & 3.13843600 & 1.05703500 \\
3.12338200 & -1.55232000 & -0.98384300
\end{array}
$$




$\begin{array}{llll}\mathrm{H} & 2.50065500 & -1.50622400 & -1.88353200 \\ \mathrm{H} & 4.17264300 & -1.56188700 & -1.29846800 \\ \mathrm{H} & 2.91710500 & -2.50106900 & -0.47729000 \\ \mathrm{~F} & 0.16127000 & -0.03103300 & -1.93676900\end{array}$

$E[\mathrm{M} 06-2 \mathrm{X} / 6-311++\mathrm{G}(\mathrm{d}, \mathrm{p})]=-1692.38298832$ Hartrees $\Delta G[\mathrm{M} 06-2 \mathrm{X} / 6-31 \mathrm{G}(\mathrm{d})]=0.288008$ Hartrees

$\begin{array}{lrrr}(\mathrm{MeCN}) & & & \\ \mathrm{Si} & -0.29376000 & 0.00440600 & -0.31031800 \\ \mathrm{Si} & 2.74630400 & 0.04173700 & 0.12777800 \\ \mathrm{Si} & -1.39237900 & -2.01733100 & 0.10455200 \\ \mathrm{Si} & -1.48023400 & 1.97503600 & 0.10656400 \\ \mathrm{O} & 1.12471200 & 0.03976900 & 0.55253400 \\ \mathrm{C} & -0.46487000 & -3.42425300 & -0.74721300 \\ \mathrm{H} & -0.99298900 & -4.37513600 & -0.60684200 \\ \mathrm{H} & -0.37036900 & -3.24858700 & -1.82444800 \\ \mathrm{H} & 0.54362700 & -3.53936100 & -0.33479900 \\ \mathrm{C} & -1.41988600 & -2.30918300 & 1.96898100 \\ \mathrm{H} & -1.94421900 & -1.50277400 & 2.49419700 \\ \mathrm{H} & -1.92867300 & -3.25061500 & 2.20823300 \\ \mathrm{H} & -0.40285400 & -2.36615900 & 2.37267400 \\ \mathrm{C} & -3.15981900 & -1.90196500 & -0.54906500 \\ \mathrm{H} & -3.17913800 & -1.67613000 & -1.62111600 \\ \mathrm{H} & -3.69168200 & -2.84901600 & -0.39809700 \\ \mathrm{H} & -3.72302000 & -1.11816800 & -0.02877900 \\ \mathrm{C} & -2.39245800 & 1.77807800 & 1.74785900 \\ \mathrm{H} & -2.92718800 & 2.70030700 & 2.00567400 \\ \mathrm{H} & -3.13208800 & 0.97023100 & 1.69805000 \\ \mathrm{H} & -1.70128600 & 1.55419300 & 2.56825900 \\ \mathrm{C} & -0.26358900 & 3.41399900 & 0.21374800 \\ \mathrm{H} & 0.31445100 & 3.51734400 & -0.71137400 \\ \mathrm{H} & -0.79391700 & 4.35877000 & 0.38369400 \\ \mathrm{C} & -2.72973800 & 2.26761400 & -1.27665100 \\ \mathrm{H} & -3.43708100 & 1.43347600 & -1.35064900 \\ \mathrm{H} & -3.30735900 & 3.18124300 & -1.09241700 \\ \mathrm{H} & -2.23381900 & 2.37336300 & -2.24774400 \\ \mathrm{C} & 3.10603800 & 1.55676300 & -0.91496100 \\ \mathrm{H} & 4.15809100 & 1.57390900 & -1.22379900 \\ \mathrm{H} & 2.49298400 & 1.57022100 & -1.82319500 \\ \mathrm{H} & 2.90909600 & 2.47881600 & -0.35636700 \\ \mathrm{C} & 3.71789000 & 0.09352700 & 1.72498400 \\ \mathrm{H} & 4.79601900 & 0.09056500 & 1.52702200 \\ \mathrm{H} & 3.48601000 & 0.99720400 & 2.29951700 \\ \mathrm{H} & 3.49038500 & -0.77362900 & 2.35484400 \\ \mathrm{H} & 0.44141600 & 3.27282300 & 1.04049300 \\ \mathrm{C} & 3.11792100 & -1.52596100 & -0.83024200 \\ \mathrm{H} & 2.46295800 & -1.61932400 & -1.70450500 \\ \mathrm{H} & 4.15441200 & -1.53346000 & -1.18763100 \\ \mathrm{H} & 2.97522800 & -2.41390000 & -0.20402800 \\ \mathrm{~F} & 0.15059400 & 0.01445100 & -1.89798100 \\ & & & \end{array}$

$E[\mathrm{M} 06-2 \mathrm{X} / 6-311++\mathrm{G}(\mathrm{d}, \mathrm{p})]=-1692.39177365$ Hartrees $\Delta G[\mathrm{M} 06-2 \mathrm{X} / 6-31 \mathrm{G}(\mathrm{d})]=0.289773$ Hartrees

(water) 


\begin{tabular}{|c|c|c|c|}
\hline $\mathrm{Si}$ & -0.29316300 & 0.00065400 & -0.31303400 \\
\hline $\mathrm{Si}$ & 2.73938500 & 0.01111300 & 0.12587400 \\
\hline $\mathrm{Si}$ & -1.42924100 & -1.99641100 & 0.10432500 \\
\hline $\mathrm{Si}$ & -1.44070200 & 1.99185000 & 0.10225800 \\
\hline $\mathrm{O}$ & 1.11874400 & -0.01636900 & 0.57225000 \\
\hline $\mathrm{C}$ & -0.48323700 & -3.40307200 & -0.72616200 \\
\hline $\mathrm{H}$ & -0.98367500 & -4.36481000 & -0.56391300 \\
\hline $\mathrm{H}$ & -0.40174700 & -3.24332900 & -1.80674600 \\
\hline $\mathrm{H}$ & 0.53173600 & -3.48188600 & -0.32087100 \\
\hline $\mathrm{C}$ & -1.46979600 & -2.25891000 & 1.97246200 \\
\hline $\mathrm{H}$ & -1.98604600 & -1.43603400 & 2.47974200 \\
\hline $\mathrm{H}$ & -1.99127900 & -3.18886800 & 2.22698100 \\
\hline $\mathrm{H}$ & -0.45538000 & -2.32105700 & 2.38130300 \\
\hline $\mathrm{C}$ & -3.18859500 & -1.86830300 & -0.56525000 \\
\hline $\mathrm{H}$ & -3.19579900 & -1.65268800 & -1.63923200 \\
\hline $\mathrm{H}$ & -3.73603200 & -2.80481200 & -0.40764300 \\
\hline $\mathrm{H}$ & -3.74124200 & -1.06914800 & -0.05720400 \\
\hline $\mathrm{C}$ & -2.37148900 & 1.76917500 & 1.72925600 \\
\hline $\mathrm{H}$ & -2.91216800 & 2.68420400 & 1.99835100 \\
\hline $\mathrm{H}$ & -3.10716800 & 0.95965100 & 1.65358600 \\
\hline $\mathrm{H}$ & -1.68983600 & 1.53054100 & 2.55305600 \\
\hline $\mathrm{C}$ & -0.20963000 & 3.41443500 & 0.24020000 \\
\hline $\mathrm{H}$ & 0.36188300 & 3.53731000 & -0.68621800 \\
\hline $\mathrm{H}$ & -0.72748500 & 4.35927800 & 0.44239600 \\
\hline $\mathrm{C}$ & -2.67608300 & 2.29523500 & -1.29019400 \\
\hline $\mathrm{H}$ & -3.38583600 & 1.46327700 & -1.36583700 \\
\hline $\mathrm{H}$ & -3.25049000 & 3.21136000 & -1.11078200 \\
\hline $\mathrm{H}$ & -2.17338800 & 2.39654500 & -2.25785700 \\
\hline $\mathrm{C}$ & 3.08042300 & 1.59010700 & -0.82175000 \\
\hline $\mathrm{H}$ & 4.12922300 & 1.63436500 & -1.13745200 \\
\hline $\mathrm{H}$ & 2.45932600 & 1.65411900 & -1.72230600 \\
\hline $\mathrm{H}$ & 2.87940400 & 2.47279300 & -0.20448000 \\
\hline $\mathrm{C}$ & 3.72119300 & -0.03553700 & 1.71618400 \\
\hline $\mathrm{H}$ & 4.79768900 & -0.03109400 & 1.51175000 \\
\hline $\mathrm{H}$ & 3.49567500 & 0.83339300 & 2.34412600 \\
\hline $\mathrm{H}$ & 3.49414300 & -0.93736700 & 2.29490000 \\
\hline $\mathrm{H}$ & 0.50023700 & 3.24032500 & 1.05634800 \\
\hline $\mathrm{C}$ & 3.09178100 & -1.49743900 & -0.92695000 \\
\hline $\mathrm{H}$ & 2.40741800 & -1.55121900 & -1.78111900 \\
\hline $\mathrm{H}$ & 4.11566800 & -1.47307700 & -1.31754500 \\
\hline $\mathrm{H}$ & 2.98057200 & -2.41925100 & -0.34509500 \\
\hline $\mathrm{F}$ & 0.17770400 & -0.00073300 & -1.89277000 \\
\hline
\end{tabular}

$E[\mathrm{M} 06-2 \mathrm{X} / 6-311++\mathrm{G}(\mathrm{d}, \mathrm{p})]=-1692.37734649$ Hartrees $\Delta G[\mathrm{M} 06-2 \mathrm{X} / 6-31 \mathrm{G}(\mathrm{d})]=0.288153$ Hartrees<smiles>CO[Si](C)([SiH3])[AsH3]</smiles>

$\begin{array}{lrrr}\text { (gas) } & & & \\ \mathrm{Si} & -0.26229600 & -0.00580800 & -0.42815500 \\ \mathrm{Si} & 2.76547600 & -0.00728800 & 0.00754700 \\ \mathrm{Si} & -1.43403500 & -1.98336600 & 0.00007500 \\ \mathrm{Si} & -1.41940100 & 1.98303500 & -0.00207100\end{array}$




$\begin{array}{lrrr}\mathrm{O} & 1.16397500 & 0.00833600 & 0.46513400 \\ \mathrm{C} & -0.62530300 & -3.45814400 & -0.86146900 \\ \mathrm{H} & -1.17183500 & -4.38285500 & -0.64433000 \\ \mathrm{H} & -0.60679500 & -3.32106700 & -1.94731200 \\ \mathrm{H} & 0.40744900 & -3.59122300 & -0.52292400 \\ \mathrm{C} & -1.47340500 & -2.30001500 & 1.86413900 \\ \mathrm{H} & -2.00194200 & -1.49613600 & 2.38691100 \\ \mathrm{H} & -1.97686300 & -3.24609600 & 2.09367600 \\ \mathrm{H} & -0.45700000 & -2.34732600 & 2.26759800 \\ \mathrm{C} & -3.19834900 & -1.75902100 & -0.64706200 \\ \mathrm{H} & -3.20675500 & -1.52775800 & -1.71742300 \\ \mathrm{H} & -3.78377600 & -2.67309700 & -0.49739400 \\ \mathrm{H} & -3.71185200 & -0.94558900 & -0.12225500 \\ \mathrm{C} & -2.31635200 & 1.89328700 & 1.66325000 \\ \mathrm{H} & -2.80714700 & 2.84564500 & 1.89562600 \\ \mathrm{H} & -3.08631300 & 1.11351100 & 1.65247900 \\ \mathrm{H} & -1.61835200 & 1.66379400 & 2.47478800 \\ \mathrm{C} & -0.15960000 & 3.38992000 & 0.03939100 \\ \mathrm{H} & 0.34758100 & 3.49257200 & -0.92565900 \\ \mathrm{H} & -0.64300900 & 4.34513200 & 0.27265500 \\ \mathrm{C} & -2.69674000 & 2.28966200 & -1.36152300 \\ \mathrm{H} & -3.41365900 & 1.46425300 & -1.42834900 \\ \mathrm{H} & -3.26160000 & 3.20625000 & -1.15794200 \\ \mathrm{H} & -2.21743700 & 2.39849800 & -2.33931300 \\ \mathrm{C} & 3.08074400 & 1.42637900 & -1.16321700 \\ \mathrm{H} & 4.11696000 & 1.43392100 & -1.51855400 \\ \mathrm{H} & 2.42704900 & 1.36003000 & -2.04119500 \\ \mathrm{H} & 2.88498000 & 2.38635800 & -0.67387600 \\ \mathrm{C} & 3.79283900 & 0.15918500 & 1.56253600 \\ \mathrm{H} & 4.86354200 & 0.15009200 & 1.33212200 \\ \mathrm{H} & 3.56793500 & 1.09654000 & 2.08088200 \\ \mathrm{H} & 3.58942300 & -0.66372000 & 2.25494500 \\ \mathrm{H} & 0.60342500 & 3.20085300 & 0.80184400 \\ \mathrm{C} & 3.12394800 & -1.62948300 & -0.86692300 \\ \mathrm{H} & 2.45681600 & -1.75863500 & -1.72787700 \\ \mathrm{H} & 4.15504100 & -1.67309400 & -1.23378900 \\ & 2.96922200 & -2.48017800 & -0.19467800\end{array}$

$E[\mathrm{M} 06-2 \mathrm{X} / 6-311++\mathrm{G}(\mathrm{d}, \mathrm{p})]=-1592.42718328$ Hartrees $\Delta G[\mathrm{M} 06-2 \mathrm{X} / 6-31 \mathrm{G}(\mathrm{d})]=0.283611$ Hartrees

$\begin{array}{lccc}(\mathrm{MeCN}) & & & \\ \mathrm{Si} & 0.26714000 & 0.00240400 & -0.39431500 \\ \mathrm{Si} & -2.75431500 & -0.03435300 & 0.00824100 \\ \mathrm{Si} & 1.39009000 & 2.01628900 & -0.00087500 \\ \mathrm{Si} & 1.45595000 & -1.97501700 & 0.00261600 \\ \mathrm{O} & -1.15948800 & -0.02799900 & 0.50732500 \\ \mathrm{C} & 0.48502400 & 3.45729700 & -0.82046400 \\ \mathrm{H} & 1.02748800 & 4.39667500 & -0.65683400 \\ \mathrm{H} & 0.38833900 & 3.30781000 & -1.90157700 \\ \mathrm{H} & -0.52201900 & 3.57901200 & -0.40591300 \\ \mathrm{C} & 1.47913600 & 2.32801600 & 1.86157000 \\ \mathrm{H} & 2.01200400 & 1.51873600 & 2.37374200 \\ \mathrm{H} & 1.99995300 & 3.26895500 & 2.07838800 \\ \mathrm{H} & 0.47453600 & 2.39304800 & 2.29443700 \\ \mathrm{C} & 3.13579600 & 1.86446200 & -0.70706200\end{array}$




$\begin{array}{lrrr}\mathrm{H} & 3.12106200 & 1.62667100 & -1.77660000 \\ \mathrm{H} & 3.67957700 & 2.80896200 & -0.58315500 \\ \mathrm{H} & 3.70701100 & 1.08261700 & -0.19298400 \\ \mathrm{C} & 2.40561400 & -1.88404600 & 1.63654100 \\ \mathrm{H} & 2.90257300 & -2.83980100 & 1.84637200 \\ \mathrm{H} & 3.17869200 & -1.10748600 & 1.59975200 \\ \mathrm{H} & 1.74080700 & -1.65874900 & 2.47783400 \\ \mathrm{C} & 0.22087900 & -3.40140800 & 0.06844600 \\ \mathrm{H} & -0.33597100 & -3.48681100 & -0.87155000 \\ \mathrm{H} & 0.73933200 & -4.35313100 & 0.23822900 \\ \mathrm{C} & 2.69102500 & -2.25264000 & -1.39797600 \\ \mathrm{H} & 3.40011100 & -1.42002700 & -1.47416300 \\ \mathrm{H} & 3.26929000 & -3.16818500 & -1.22325200 \\ \mathrm{H} & 2.18531800 & -2.35314300 & -2.36449400 \\ \mathrm{C} & -3.02926700 & -1.47946200 & -1.15482400 \\ \mathrm{H} & -4.06108600 & -1.48980200 & -1.52641100 \\ \mathrm{H} & -2.36531300 & -1.41820900 & -2.02627400 \\ \mathrm{H} & -2.84598400 & -2.43798100 & -0.65599600 \\ \mathrm{C} & -3.81608700 & -0.19740500 & 1.53852100 \\ \mathrm{H} & -4.88066000 & -0.19228900 & 1.27679900 \\ \mathrm{H} & -3.60805500 & -1.13218300 & 2.07085600 \\ \mathrm{H} & -3.63865200 & 0.63225400 & 2.23212000 \\ \mathrm{H} & -0.50226600 & -3.26650200 & 0.88057200 \\ \mathrm{C} & -3.11321700 & 1.57544700 & -0.88520500 \\ \mathrm{H} & -2.43160900 & 1.71552100 & -1.73410000 \\ \mathrm{H} & -4.13765300 & 1.59080200 & -1.27589200 \\ \mathrm{H} & -2.99845500 & 2.43514700 & -0.21512500\end{array}$

$E[\mathrm{M} 06-2 \mathrm{X} / 6-311++\mathrm{G}(\mathrm{d}, \mathrm{p})]=-1592.43401771$ Hartrees $\Delta G[\mathrm{M} 06-2 \mathrm{X} / 6-31 \mathrm{G}(\mathrm{d})]=0.286086$ Hartrees

$\begin{array}{lccc}\text { (water) } & & & \\ \mathrm{Si} & 0.25039100 & -0.00184000 & -0.38387200 \\ \mathrm{Si} & -2.74790400 & -0.04903900 & 0.00275400 \\ \mathrm{Si} & 1.36674200 & 2.01673400 & -0.00111400 \\ \mathrm{Si} & 1.46762300 & -1.96113800 & 0.00313800 \\ \mathrm{O} & -1.16279000 & -0.06143900 & 0.55439100 \\ \mathrm{C} & 0.47238000 & 3.46078400 & -0.82475200 \\ \mathrm{H} & 1.02583400 & 4.39499200 & -0.67173800 \\ \mathrm{H} & 0.36657000 & 3.30373300 & -1.90357200 \\ \mathrm{H} & -0.53044200 & 3.59565900 & -0.40453100 \\ \mathrm{C} & 1.45159000 & 2.31721300 & 1.86235800 \\ \mathrm{H} & 1.98396900 & 1.50325000 & 2.36733400 \\ \mathrm{H} & 1.97078700 & 3.25621900 & 2.08897500 \\ \mathrm{H} & 0.44608300 & 2.37719300 & 2.29322800 \\ \mathrm{C} & 3.11070300 & 1.84045200 & -0.70430900 \\ \mathrm{H} & 3.09342600 & 1.60578700 & -1.77427800 \\ \mathrm{H} & 3.67009900 & 2.77486000 & -0.57651800 \\ \mathrm{H} & 3.66626500 & 1.04658600 & -0.19154000 \\ \mathrm{C} & 2.43033400 & -1.82837400 & 1.62511500 \\ \mathrm{H} & 2.95400000 & -2.76693900 & 1.84503000 \\ \mathrm{H} & 3.18125800 & -1.03173900 & 1.56876200 \\ \mathrm{H} & 1.76713500 & -1.60748000 & 2.46841700 \\ \mathrm{C} & 0.23812600 & -3.38934200 & 0.09964600 \\ \mathrm{H} & -0.32228200 & -3.48938500 & -0.83652600 \\ \mathrm{H} & 0.75528100 & -4.33814700 & 0.28536400\end{array}$




$\begin{array}{lrrr}\mathrm{C} & 2.68903500 & -2.23100100 & -1.40870900 \\ \mathrm{H} & 3.38684700 & -1.38976400 & -1.49104400 \\ \mathrm{H} & 3.27884200 & -3.13948600 & -1.23888500 \\ \mathrm{H} & 2.17506200 & -2.33687800 & -2.36980300 \\ \mathrm{C} & -2.99570900 & -1.50792600 & -1.14661100 \\ \mathrm{H} & -4.02048800 & -1.53110300 & -1.53537600 \\ \mathrm{H} & -2.31625100 & -1.45415500 & -2.00603000 \\ \mathrm{H} & -2.81374600 & -2.45709600 & -0.62984200 \\ \mathrm{C} & -3.85796500 & -0.17835900 & 1.50019500 \\ \mathrm{H} & -4.91216600 & -0.15058400 & 1.20227000 \\ \mathrm{H} & -3.68957200 & -1.11492100 & 2.04274900 \\ \mathrm{H} & -3.68468600 & 0.65101300 & 2.19446700 \\ \mathrm{H} & -0.48267900 & -3.23700100 & 0.91063000 \\ \mathrm{C} & -3.04503500 & 1.56014500 & -0.91176600 \\ \mathrm{H} & -2.35315700 & 1.67170000 & -1.75601100 \\ \mathrm{H} & -4.06535800 & 1.60759000 & -1.30946700 \\ \mathrm{H} & -2.90498900 & 2.42002800 & -0.24686600\end{array}$

$E[\mathrm{M} 06-2 \mathrm{X} / 6-311++\mathrm{G}(\mathrm{d}, \mathrm{p})]=-1592.42019437$ Hartrees $\Delta G[\mathrm{M} 06-2 \mathrm{X} / 6-31 \mathrm{G}(\mathrm{d})]=0.286265$ Hartrees

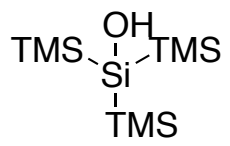

$\begin{array}{lrrr}\text { (gas) } & & & \\ \mathrm{Si} & 0.00583300 & -0.01365700 & -0.67589800 \\ \mathrm{Si} & -2.17419600 & -0.39349300 & 0.09843300 \\ \mathrm{Si} & 1.43818400 & -1.68834600 & 0.10335700 \\ \mathrm{Si} & 0.74625500 & 2.07936900 & 0.08922200 \\ \mathrm{O} & 0.07047000 & -0.11037500 & -2.37513100 \\ \mathrm{C} & 1.16916400 & -3.26777700 & -0.89601500 \\ \mathrm{H} & 1.85600200 & -4.05871100 & -0.57447600 \\ \mathrm{H} & 0.14566300 & -3.63853200 & -0.77811700 \\ \mathrm{H} & 1.33547900 & -3.08083000 & -1.96141400 \\ \mathrm{C} & 3.24657400 & -1.15152400 & -0.04298300 \\ \mathrm{H} & 3.45306300 & -0.27213000 & 0.57746500 \\ \mathrm{H} & 3.91889600 & -1.95391300 & 0.28143800 \\ \mathrm{H} & 3.49806300 & -0.89845800 & -1.07824900 \\ \mathrm{C} & 1.03838300 & -2.01090500 & 1.92594600 \\ \mathrm{H} & 0.02429900 & -2.40939200 & 2.04265600 \\ \mathrm{H} & 1.73425800 & -2.74105500 & 2.35409500 \\ \mathrm{H} & 1.10806300 & -1.09322500 & 2.52045100 \\ \mathrm{C} & 2.26632500 & 2.61928500 & -0.89818000 \\ \mathrm{H} & 2.61766800 & 3.60513100 & -0.57390100 \\ \mathrm{H} & 3.08712500 & 1.90615200 & -0.76870000 \\ \mathrm{H} & 2.04254800 & 2.67277100 & -1.96837500 \\ \mathrm{C} & -0.60564500 & 3.39717100 & -0.08615600 \\ \mathrm{H} & -1.49243400 & 3.13403200 & 0.50155300 \\ \mathrm{H} & -0.24774300 & 4.37096800 & 0.26693700 \\ \mathrm{C} & 1.21258200 & 1.94538800 & 1.91967200 \\ \mathrm{H} & 2.04614300 & 1.24977100 & 2.06713800 \\ \mathrm{H} & 1.52215500 & 2.92189200 & 2.30933900 \\ \mathrm{H} & 0.37134600 & 1.59444000 & 2.52707700\end{array}$




$\begin{array}{lrrr}\mathrm{C} & -2.29943600 & 0.15134800 & 1.90805100 \\ \mathrm{H} & -3.30094200 & -0.05332600 & 2.30365000 \\ \mathrm{H} & -1.57752700 & -0.38510700 & 2.53404100 \\ \mathrm{H} & -2.11058700 & 1.22475900 & 2.02218600 \\ \mathrm{C} & -3.40989800 & 0.60544800 & -0.93435700 \\ \mathrm{H} & -4.42911700 & 0.46881000 & -0.55587000 \\ \mathrm{H} & -3.18272800 & 1.67659800 & -0.90700700 \\ \mathrm{H} & -3.40146900 & 0.28429300 & -1.98171200 \\ \mathrm{H} & -0.92024300 & 3.51687200 & -1.12876900 \\ \mathrm{C} & -2.64166000 & -2.22405600 & -0.01325800 \\ \mathrm{H} & -2.01251400 & -2.83417300 & 0.64429400 \\ \mathrm{H} & -3.68484500 & -2.37959000 & 0.28463500 \\ \mathrm{H} & -2.52272600 & -2.60292700 & -1.03380500 \\ \mathrm{H} & -0.52505000 & 0.49738900 & -2.83341100\end{array}$

$E[\mathrm{M} 06-2 \mathrm{X} / 6-311++\mathrm{G}(\mathrm{d}, \mathrm{p})]=-1593.02316183$ Hartrees $\Delta G[\mathrm{M} 06-2 \mathrm{X} / 6-31 \mathrm{G}(\mathrm{d})]=0.298637$ Hartrees

$\begin{array}{lrrr}(\mathrm{MeCN}) & & & \\ \mathrm{Si} & -0.00513700 & -0.00386700 & -0.66930400 \\ \mathrm{Si} & -0.21464100 & 2.20034400 & 0.10366500 \\ \mathrm{Si} & -1.80349300 & -1.29204400 & 0.09726200 \\ \mathrm{Si} & 2.01758400 & -0.91678200 & 0.09503300 \\ \mathrm{O} & -0.09673500 & -0.04563100 & -2.37488100 \\ \mathrm{C} & -3.35408800 & -0.88890700 & -0.90539000 \\ \mathrm{H} & -4.20895400 & -1.47892000 & -0.55311400 \\ \mathrm{H} & -3.61899400 & 0.17113500 & -0.82079200 \\ \mathrm{H} & -3.20706800 & -1.11277500 & -1.96775700 \\ \mathrm{C} & -1.43701600 & -3.14078300 & -0.05255400 \\ \mathrm{H} & -0.58453200 & -3.42910600 & 0.57378000 \\ \mathrm{H} & -2.30228400 & -3.73278600 & 0.27096600 \\ \mathrm{H} & -1.20821000 & -3.42311800 & -1.08643700 \\ \mathrm{C} & -2.11682400 & -0.88148900 & 1.91599700 \\ \mathrm{H} & -2.41152100 & 0.16668200 & 2.04487300 \\ \mathrm{H} & -2.92807100 & -1.50382200 & 2.31416600 \\ \mathrm{H} & -1.22871800 & -1.06232900 & 2.53225600 \\ \mathrm{C} & 2.44845100 & -2.46507200 & -0.90140500 \\ \mathrm{H} & 3.40131600 & -2.89122800 & -0.56464500 \\ \mathrm{H} & 1.67816500 & -3.23717900 & -0.79307400 \\ \mathrm{H} & 2.54162500 & -2.23642200 & -1.96901700 \\ \mathrm{C} & 3.43962800 & 0.32047500 & -0.07389000 \\ \mathrm{H} & 3.26778100 & 1.21384800 & 0.53778500 \\ \mathrm{H} & 4.38465600 & -0.13063900 & 0.25351700 \\ \mathrm{C} & 1.84084600 & -1.38963700 & 1.91779100 \\ \mathrm{H} & 1.08955300 & -2.17612900 & 2.05548200 \\ \mathrm{H} & 2.79349000 & -1.77018600 & 2.30707400 \\ \mathrm{H} & 1.55011700 & -0.53177300 & 2.53457800 \\ \mathrm{C} & 0.32618800 & 2.29481000 & 1.91353200 \\ \mathrm{H} & 0.19453700 & 3.31473600 & 2.29625900 \\ \mathrm{H} & -0.26401100 & 1.62434200 & 2.54880700 \\ \mathrm{H} & 1.38361400 & 2.03177300 & 2.03305800 \\ \mathrm{C} & 0.88373000 & 3.34681300 & -0.92616300 \\ \mathrm{H} & 0.80661400 & 4.38087800 & -0.56829200 \\ \mathrm{H} & 1.93779900 & 3.05053300 & -0.87237600 \\ \mathrm{H} & 0.58901000 & 3.33882300 & -1.98198100 \\ \mathrm{H} & 3.56840400 & 0.64508700 & -1.11296800\end{array}$




$\begin{array}{lrrr}\mathrm{C} & -2.00255200 & 2.80578700 & -0.02610600 \\ \mathrm{H} & -2.66998700 & 2.21304600 & 0.61011400 \\ \mathrm{H} & -2.08098400 & 3.85257900 & 0.29333500 \\ \mathrm{H} & -2.37452100 & 2.74334000 & -1.05519000 \\ \mathrm{H} & 0.58449900 & 0.49557100 & -2.80540700\end{array}$

$E[\mathrm{M} 06-2 \mathrm{X} / 6-311++\mathrm{G}(\mathrm{d}, \mathrm{p})]=-1593.03254818$ Hartrees $\Delta G[\mathrm{M} 06-2 \mathrm{X} / 6-31 \mathrm{G}(\mathrm{d})]=0.296890$ Hartrees

$\begin{array}{lrrr}\text { (water) } & & & \\ \mathrm{Si} & 0.00239800 & -0.00552500 & -0.67114200 \\ \mathrm{Si} & -1.92087100 & -1.08813400 & 0.11025400 \\ \mathrm{Si} & 1.91689000 & -1.10519900 & 0.10434500 \\ \mathrm{Si} & 0.00964900 & 2.21461900 & 0.08070400 \\ \mathrm{O} & 0.07420900 & -0.12474600 & -2.38499100 \\ \mathrm{C} & 2.20662800 & -2.64850800 & -0.94553700 \\ \mathrm{H} & 3.09316300 & -3.19294100 & -0.59952000 \\ \mathrm{H} & 1.35015200 & -3.33062000 & -0.89267000 \\ \mathrm{H} & 2.36181500 & -2.38940600 & -1.99841100 \\ \mathrm{C} & 3.43552600 & 0.01499200 & 0.00558400 \\ \mathrm{H} & 3.31927900 & 0.89078600 & 0.65447300 \\ \mathrm{H} & 4.33700900 & -0.52108300 & 0.32599400 \\ \mathrm{H} & 3.60343500 & 0.37285400 & -1.01615200 \\ \mathrm{C} & 1.64078400 & -1.61662100 & 1.90252100 \\ \mathrm{H} & 0.76697400 & -2.27100500 & 2.00151100 \\ \mathrm{H} & 2.51160800 & -2.16472900 & 2.28212000 \\ \mathrm{H} & 1.48657100 & -0.74543500 & 2.54925900 \\ \mathrm{C} & 1.25325500 & 3.24325300 & -0.90240000 \\ \mathrm{H} & 1.25602200 & 4.28476400 & -0.56001100 \\ \mathrm{H} & 2.26813400 & 2.84659000 & -0.78602500 \\ \mathrm{H} & 1.01565600 & 3.24105300 & -1.97165400 \\ \mathrm{C} & -1.70369500 & 3.00409500 & -0.05038300 \\ \mathrm{H} & -2.45401900 & 2.41406100 & 0.48907100 \\ \mathrm{H} & -1.69820400 & 4.01208500 & 0.38222000 \\ \mathrm{C} & 0.52377000 & 2.19663300 & 1.90118700 \\ \mathrm{H} & 1.54944900 & 1.82923100 & 2.02290800 \\ \mathrm{H} & 0.48064100 & 3.20948100 & 2.31962500 \\ \mathrm{H} & -0.13578300 & 1.56118100 & 2.50339500 \\ \mathrm{C} & -2.21081300 & -0.64038600 & 1.92314600 \\ \mathrm{H} & -3.10076600 & -1.15603500 & 2.30347000 \\ \mathrm{H} & -1.36134800 & -0.93286200 & 2.55100100 \\ \mathrm{H} & -2.37059900 & 0.43660400 & 2.05041800 \\ \mathrm{C} & -3.40582200 & -0.53268800 & -0.92142600 \\ \mathrm{H} & -4.32003500 & -1.04771000 & -0.60416300 \\ \mathrm{H} & -3.57446200 & 0.54599900 & -0.82480900 \\ \mathrm{H} & -3.25041800 & -0.75118000 & -1.98402900 \\ \mathrm{H} & -2.03012400 & 3.09024700 & -1.09269500 \\ \mathrm{C} & -1.73899700 & -2.96367800 & -0.03706900 \\ \mathrm{H} & -0.89966700 & -3.32928000 & 0.56595600 \\ \mathrm{H} & -2.64682500 & -3.47090600 & 0.31119800 \\ \mathrm{H} & -1.56383100 & -3.26820300 & -1.07496400 \\ \mathrm{H} & -0.70422800 & 0.27122700 & -2.81956500\end{array}$

$E[\mathrm{M} 06-2 \mathrm{X} / 6-311++\mathrm{G}(\mathrm{d}, \mathrm{p})]=-1593.02233879$ Hartrees $\Delta G[\mathrm{M} 06-2 \mathrm{X} / 6-31 \mathrm{G}(\mathrm{d})]=0.298597$ Hartrees 


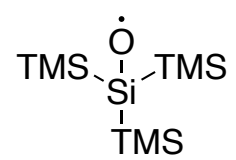

$\begin{array}{lrrr}\text { (gas) } & & & \\ \mathrm{Si} & 0.00905300 & -0.07451500 & -0.75225400 \\ \mathrm{Si} & -0.05752500 & 2.17116700 & 0.15808700 \\ \mathrm{Si} & -1.92904800 & -1.16080800 & 0.03765000 \\ \mathrm{Si} & 2.00259100 & -1.05437800 & 0.02408800 \\ \mathrm{O} & -0.04858400 & 0.56728500 & -2.22808700 \\ \mathrm{C} & -3.42247000 & -0.60623700 & -0.97239100 \\ \mathrm{H} & -4.31124700 & -1.18980100 & -0.70767700 \\ \mathrm{H} & -3.64641700 & 0.45104500 & -0.80091300 \\ \mathrm{H} & -3.23118800 & -0.73417400 & -2.04199900 \\ \mathrm{C} & -1.68678600 & -3.03024100 & -0.14199200 \\ \mathrm{H} & -0.82689500 & -3.37571300 & 0.44311400 \\ \mathrm{H} & -2.57122200 & -3.57088000 & 0.21400100 \\ \mathrm{H} & -1.51691400 & -3.31227600 & -1.18614500 \\ \mathrm{C} & -2.20346400 & -0.78506600 & 1.87376100 \\ \mathrm{H} & -2.42758500 & 0.27304300 & 2.04748000 \\ \mathrm{H} & -3.04846300 & -1.36908700 & 2.25650700 \\ \mathrm{H} & -1.32193200 & -1.04598000 & 2.46978300 \\ \mathrm{C} & 2.42277900 & -2.59547500 & -0.98717400 \\ \mathrm{H} & 3.33574500 & -3.06702000 & -0.60599000 \\ \mathrm{H} & 1.61554200 & -3.33368200 & -0.93651500 \\ \mathrm{H} & 2.58422800 & -2.34581200 & -2.04020100 \\ \mathrm{C} & 3.44680500 & 0.16113400 & -0.05276200 \\ \mathrm{H} & 3.29576600 & 1.00787800 & 0.62581600 \\ \mathrm{H} & 4.38177400 & -0.33333800 & 0.23423500 \\ \mathrm{C} & 1.70153100 & -1.56902700 & 1.82215600 \\ \mathrm{H} & 0.90471900 & -2.31828000 & 1.89413300 \\ \mathrm{H} & 2.60875100 & -2.01036500 & 2.25046200 \\ \mathrm{H} & 1.41714700 & -0.71636800 & 2.44819100 \\ \mathrm{C} & 0.41638900 & 2.09051500 & 1.98646500 \\ \mathrm{H} & 0.32715100 & 3.08822300 & 2.43338600 \\ \mathrm{H} & -0.23242800 & 1.41009200 & 2.54695700 \\ \mathrm{H} & 1.45207500 & 1.75860800 & 2.11342000 \\ \mathrm{C} & 1.15098600 & 3.23523100 & -0.80554800 \\ \mathrm{H} & 1.12298100 & 4.27162200 & -0.45000200 \\ \mathrm{H} & 2.17686600 & 2.86804500 & -0.70670100 \\ \mathrm{H} & 0.88729000 & 3.21422300 & -1.86616400 \\ \mathrm{H} & 3.57071900 & 0.55807700 & -1.06541600 \\ \mathrm{C} & -1.82030500 & 2.79330900 & -0.05370400 \\ \mathrm{H} & -2.52750800 & 2.22946900 & 0.56313500 \\ \mathrm{H} & -1.88853200 & 3.84917900 & 0.23317800 \\ \mathrm{H} & -2.12553700 & 2.69959400 & -1.10022600 \\ & & & \end{array}$

$E[\mathrm{M} 06-2 \mathrm{X} / 6-311++\mathrm{G}(\mathrm{d}, \mathrm{p})]=-1592.34843349$ Hartrees $\Delta G[\mathrm{M} 06-2 \mathrm{X} / 6-31 \mathrm{G}(\mathrm{d})]=0.285661$ Hartrees

$\begin{array}{lrrr}(\mathrm{MeCN}) & & & \\ \mathrm{Si} & 0.01759100 & -0.09170700 & -0.80091000 \\ \mathrm{Si} & -0.09922900 & 2.16799900 & 0.15293800 \\ \mathrm{Si} & -1.91126100 & -1.15915600 & 0.05173200\end{array}$




\begin{tabular}{|c|c|c|c|}
\hline $\mathrm{Si}$ & 2.02229200 & -0.99584700 & 0.05041200 \\
\hline $\mathrm{O}$ & -0.02361900 & 0.39780700 & -2.32417700 \\
\hline $\mathrm{C}$ & -3.42464800 & -0.65147300 & -0.95650300 \\
\hline $\mathrm{H}$ & -4.30660900 & -1.21746200 & -0.63278500 \\
\hline $\mathrm{H}$ & -3.64725700 & 0.41479000 & -0.83946500 \\
\hline $\mathrm{H}$ & -3.27000800 & -0.84692800 & -2.02331700 \\
\hline $\mathrm{C}$ & -1.64292200 & -3.02493200 & -0.10484900 \\
\hline $\mathrm{H}$ & -0.79032100 & -3.35421700 & 0.50078800 \\
\hline $\mathrm{H}$ & -2.53031000 & -3.56658200 & 0.24606400 \\
\hline $\mathrm{H}$ & -1.45539200 & -3.32289400 & -1.14266000 \\
\hline $\mathrm{C}$ & -2.18745300 & -0.76204800 & 1.87817400 \\
\hline $\mathrm{H}$ & -2.43216500 & 0.29329200 & 2.04199000 \\
\hline $\mathrm{H}$ & -3.02603100 & -1.35938000 & 2.25846900 \\
\hline $\mathrm{H}$ & -1.30605900 & -1.00604500 & 2.48247700 \\
\hline $\mathrm{C}$ & 2.47673200 & -2.51189600 & -0.98400600 \\
\hline $\mathrm{H}$ & 3.38210600 & -2.98922000 & -0.58902500 \\
\hline $\mathrm{H}$ & 1.67173300 & -3.25600800 & -0.97199300 \\
\hline $\mathrm{H}$ & 2.66804300 & -2.24135900 & -2.02836900 \\
\hline $\mathrm{C}$ & 3.44524100 & 0.24254100 & -0.00057500 \\
\hline $\mathrm{H}$ & 3.25874500 & 1.10272400 & 0.65238800 \\
\hline $\mathrm{H}$ & 4.37365100 & -0.23597400 & 0.33520300 \\
\hline $\mathrm{C}$ & 1.70472000 & -1.55213400 & 1.82761000 \\
\hline $\mathrm{H}$ & 0.92064200 & -2.31798600 & 1.86791300 \\
\hline $\mathrm{H}$ & 2.61724000 & -1.99150500 & 2.24990300 \\
\hline $\mathrm{H}$ & 1.40412300 & -0.72141700 & 2.47531700 \\
\hline $\mathrm{C}$ & 0.38097100 & 2.03814600 & 1.96683300 \\
\hline $\mathrm{H}$ & 0.28692800 & 3.03186200 & 2.42490800 \\
\hline $\mathrm{H}$ & -0.26832700 & 1.35161300 & 2.51955300 \\
\hline $\mathrm{H}$ & 1.41937600 & 1.71099900 & 2.08678700 \\
\hline $\mathrm{C}$ & 1.09563900 & 3.25225900 & -0.80038800 \\
\hline $\mathrm{H}$ & 1.06890100 & 4.27281700 & -0.39823200 \\
\hline $\mathrm{H}$ & 2.12517200 & 2.88713400 & -0.72762400 \\
\hline $\mathrm{H}$ & 0.81953900 & 3.29091700 & -1.85834400 \\
\hline $\mathrm{H}$ & 3.61107600 & 0.61640300 & -1.01720500 \\
\hline $\mathrm{C}$ & -1.86906500 & 2.75404900 & -0.05753700 \\
\hline $\mathrm{H}$ & -2.57056400 & 2.14932200 & 0.52631800 \\
\hline $\mathrm{H}$ & -1.94923400 & 3.79155000 & 0.29227500 \\
\hline $\mathrm{H}$ & -2.17283500 & 2.72598800 & -1.10887400 \\
\hline
\end{tabular}

$E[\mathrm{M} 06-2 \mathrm{X} / 6-311++\mathrm{G}(\mathrm{d}, \mathrm{p})]=-1592.36305541$ Hartrees $\Delta G[\mathrm{M} 06-2 \mathrm{X} / 6-31 \mathrm{G}(\mathrm{d})]=0.286430$ Hartrees

$\begin{array}{lrrr}\text { (water) } & & & \\ \mathrm{Si} & -0.02452400 & -0.11419400 & -0.81787200 \\ \mathrm{Si} & 0.24573300 & 2.15630800 & 0.15731000 \\ \mathrm{Si} & -2.07627900 & -0.87473100 & 0.07070300 \\ \mathrm{Si} & 1.85323600 & -1.25060800 & 0.05497600 \\ \mathrm{O} & -0.01438200 & 0.31968600 & -2.35549100 \\ \mathrm{C} & -3.49643800 & -0.15857300 & -0.93937600 \\ \mathrm{H} & -4.45145900 & -0.59217100 & -0.62002800 \\ \mathrm{H} & -3.56252600 & 0.92814300 & -0.82099200 \\ \mathrm{H} & -3.36724600 & -0.37303300 & -2.00554100 \\ \mathrm{C} & -2.06131400 & -2.75968800 & -0.06655500 \\ \mathrm{H} & -1.27041100 & -3.19246800 & 0.55703800 \\ \mathrm{H} & -3.01861100 & -3.17327400 & 0.27367700 \\ \mathrm{H} & -1.89868000 & -3.09148800 & -1.09762500\end{array}$




$\begin{array}{lrrr}\mathrm{C} & -2.24792700 & -0.40491500 & 1.88934500 \\ \mathrm{H} & -2.25862800 & 0.68078200 & 2.03314300 \\ \mathrm{H} & -3.18654700 & -0.80383400 & 2.29266300 \\ \mathrm{H} & -1.42618200 & -0.82069700 & 2.48337400 \\ \mathrm{C} & 2.06109000 & -2.83758200 & -0.94599500 \\ \mathrm{H} & 2.89000200 & -3.43269800 & -0.54438200 \\ \mathrm{H} & 1.15337100 & -3.45022600 & -0.90548800 \\ \mathrm{H} & 2.27656500 & -2.62301800 & -1.99786200 \\ \mathrm{C} & 3.43347100 & -0.22751700 & -0.03044900 \\ \mathrm{H} & 3.38752700 & 0.64403800 & 0.63151900 \\ \mathrm{H} & 4.29076000 & -0.83765100 & 0.27883900 \\ \mathrm{C} & 1.45010200 & -1.70473400 & 1.84178300 \\ \mathrm{H} & 0.55761300 & -2.33909000 & 1.89487000 \\ \mathrm{H} & 2.28274600 & -2.26887200 & 2.27977700 \\ \mathrm{H} & 1.27968400 & -0.82177200 & 2.46656000 \\ \mathrm{C} & 0.70977300 & 1.97930000 & 1.96465400 \\ \mathrm{H} & 0.73972000 & 2.98671600 & 2.40117200 \\ \mathrm{H} & -0.01969100 & 1.39043600 & 2.52858800 \\ \mathrm{H} & 1.70098200 & 1.53283000 & 2.09043500 \\ \mathrm{C} & 1.58783500 & 2.98567400 & -0.84966000 \\ \mathrm{H} & 1.77453200 & 3.98765100 & -0.44341300 \\ \mathrm{H} & 2.52735200 & 2.42552700 & -0.81872600 \\ \mathrm{H} & 1.27949800 & 3.08924800 & -1.89398200 \\ \mathrm{H} & 3.62547300 & 0.12681300 & -1.04883000 \\ \mathrm{C} & -1.41908800 & 2.98312700 & -0.08080600 \\ \mathrm{H} & -2.20057800 & 2.51190400 & 0.52352800 \\ \mathrm{H} & -1.34427200 & 4.03399700 & 0.22756300 \\ \mathrm{H} & -1.72528800 & 2.95930700 & -1.13124300\end{array}$

$E[\mathrm{M} 06-2 \mathrm{X} / 6-311++\mathrm{G}(\mathrm{d}, \mathrm{p})]=-1592.35953546$ Hartrees $\Delta G[\mathrm{M} 06-2 \mathrm{X} / 6-31 \mathrm{G}(\mathrm{d})]=0.285804$ Hartrees<smiles>CS(=O)[Si](C)(C)C</smiles>

$\begin{array}{lrrr}\text { (gas) } & & & \\ \mathrm{Si} & -0.00000500 & 1.07584200 & -0.00000800 \\ \mathrm{Si} & -1.99605400 & -0.18967200 & -0.00215100 \\ \mathrm{Si} & 1.99603300 & -0.18970400 & 0.00208000 \\ \mathrm{O} & -0.00000600 & 2.61566500 & 0.00005700 \\ \mathrm{C} & 3.44420700 & 0.88599600 & 0.53785500 \\ \mathrm{H} & 4.38579100 & 0.32870900 & 0.48481400 \\ \mathrm{H} & 3.52765900 & 1.76654500 & -0.10595000 \\ \mathrm{H} & 3.31325300 & 1.23875100 & 1.56504300 \\ \mathrm{C} & 1.74620900 & -1.63419600 & 1.19830600 \\ \mathrm{H} & 0.89433400 & -2.25796200 & 0.90519300 \\ \mathrm{H} & 2.63451300 & -2.27564900 & 1.21085200 \\ \mathrm{C} & 2.27548200 & -0.87975200 & -1.73572500 \\ \mathrm{H} & 2.42522200 & -0.07958700 & -2.46672200 \\ \mathrm{H} & 3.16702700 & -1.51665900 & -1.74758500 \\ \mathrm{H} & 1.42683400 & -1.48749600 & -2.06664800 \\ \mathrm{C} & -1.74588900 & -1.63495100 & -1.19735500 \\ \mathrm{H} & -2.63418600 & -2.27642100 & -1.20961800 \\ \mathrm{H} & -1.57236900 & -1.28800800 & -2.22128200\end{array}$




$\begin{array}{lrrr}H & -0.89407800 & -2.25846800 & -0.90353200 \\ \mathrm{C} & -2.27595500 & -0.87882900 & 1.73594400 \\ \mathrm{H} & -3.16753300 & -1.51568400 & 1.74792500 \\ \mathrm{H} & -1.42738700 & -1.48647100 & 2.06726000 \\ \mathrm{H} & -2.42576300 & -0.07832600 & 2.46655200 \\ \mathrm{H} & 1.57293400 & -1.28645800 & 2.22200800 \\ \mathrm{C} & -3.44402400 & 0.88576100 & -0.53898200 \\ \mathrm{H} & -3.31242000 & 1.23851600 & -1.56608700 \\ \mathrm{H} & -4.38556300 & 0.32834000 & -0.48657200 \\ \mathrm{H} & -3.52804100 & 1.76631200 & 0.10474900\end{array}$

$E[\mathrm{M} 06-2 \mathrm{X} / 6-311++\mathrm{G}(\mathrm{d}, \mathrm{p})]=-1183.14507519$ Hartrees $\Delta G[\mathrm{M} 06-2 \mathrm{X} / 6-31 \mathrm{G}(\mathrm{d})]=0.184263$ Hartrees

$\begin{array}{lccc}(\mathrm{MeCN}) & & & \\ \mathrm{Si} & -0.00000300 & 1.07565700 & 0.00000600 \\ \mathrm{Si} & -1.99325900 & -0.19584500 & -0.00174200 \\ \mathrm{Si} & 1.99325800 & -0.19583500 & 0.00176200 \\ \mathrm{O} & -0.00000100 & 2.62406300 & -0.00001100 \\ \mathrm{C} & 3.44341500 & 0.86831600 & 0.55530700 \\ \mathrm{H} & 4.36741200 & 0.27804300 & 0.56871500 \\ \mathrm{H} & 3.59310300 & 1.71309100 & -0.12565000 \\ \mathrm{H} & 3.28382000 & 1.26947900 & 1.56163400 \\ \mathrm{C} & 1.71187100 & -1.63145700 & 1.19212500 \\ \mathrm{H} & 0.85063900 & -2.24106300 & 0.89513300 \\ \mathrm{H} & 2.59231300 & -2.28577500 & 1.20344000 \\ \mathrm{C} & 2.27138900 & -0.85893600 & -1.74193400 \\ \mathrm{H} & 2.42764400 & -0.04850700 & -2.46153900 \\ \mathrm{H} & 3.16060800 & -1.50070200 & -1.75933200 \\ \mathrm{H} & 1.41880500 & -1.45661000 & -2.08291800 \\ \mathrm{C} & -1.71185800 & -1.63136900 & -1.19223000 \\ \mathrm{H} & -2.59224900 & -2.28575500 & -1.20354400 \\ \mathrm{H} & -1.54490800 & -1.27940700 & -2.21616000 \\ \mathrm{H} & -0.85054600 & -2.24092300 & -0.89536200 \\ \mathrm{C} & -2.27136200 & -0.85900900 & 1.74193400 \\ \mathrm{H} & -3.16055000 & -1.50081900 & 1.75931600 \\ \mathrm{H} & -1.41875200 & -1.45664400 & 2.08292100 \\ \mathrm{H} & -2.42766600 & -0.04859500 & 2.46154400 \\ \mathrm{H} & 1.54481900 & -1.27961800 & 2.21608100 \\ \mathrm{C} & -3.44345000 & 0.86830100 & -0.55522400 \\ \mathrm{H} & -3.28385400 & 1.26953900 & -1.56152000 \\ \mathrm{H} & -4.36741500 & 0.27798000 & -0.56868700 \\ \mathrm{H} & -3.59318900 & 1.71302600 & 0.12578400\end{array}$

$E[\mathrm{M} 06-2 \mathrm{X} / 6-311++\mathrm{G}(\mathrm{d}, \mathrm{p})]=-1183.16301479$ Hartrees $\Delta G[\mathrm{M} 06-2 \mathrm{X} / 6-31 \mathrm{G}(\mathrm{d})]=0.182410$ Hartrees

$\begin{array}{lrrc}\text { (water) } & & & \\ \mathrm{Si} & 0.00000400 & 1.07032400 & -0.00000900 \\ \mathrm{Si} & -1.99379100 & -0.19698900 & -0.00125400 \\ \mathrm{Si} & 1.99379600 & -0.19698900 & 0.00127900 \\ \mathrm{O} & 0.00001000 & 2.62593100 & -0.00001600 \\ \mathrm{C} & 3.44585600 & 0.86608200 & 0.54446700 \\ \mathrm{H} & 4.36663600 & 0.27159200 & 0.56093500 \\ \mathrm{H} & 3.59805400 & 1.70432600 & -0.14331500 \\ \mathrm{H} & 3.28868400 & 1.27412600 & 1.54787400\end{array}$




$\begin{array}{lrrr}\mathrm{C} & 1.69246700 & -1.62076100 & 1.19836000 \\ \mathrm{H} & 0.83221200 & -2.22799500 & 0.89496600 \\ \mathrm{H} & 2.56999000 & -2.27805200 & 1.22298900 \\ \mathrm{C} & 2.24023000 & -0.86244500 & -1.74428800 \\ \mathrm{H} & 2.40885800 & -0.05495700 & -2.46377500 \\ \mathrm{H} & 3.11309400 & -1.52527900 & -1.77007700 \\ \mathrm{H} & 1.36964300 & -1.43869100 & -2.07610000 \\ \mathrm{C} & -1.69250600 & -1.62069900 & -1.19842100 \\ \mathrm{H} & -2.56999400 & -2.27803800 & -1.22300000 \\ \mathrm{H} & -1.51581800 & -1.26054500 & -2.21738200 \\ \mathrm{H} & -0.83217900 & -2.22790600 & -0.89518600 \\ \mathrm{C} & -2.24019400 & -0.86244100 & 1.74431400 \\ \mathrm{H} & -3.11313100 & -1.52517800 & 1.77015300 \\ \mathrm{H} & -1.36965000 & -1.43877900 & 2.07607800 \\ \mathrm{H} & -2.40869500 & -0.05493300 & 2.46380800 \\ \mathrm{H} & 1.51562800 & -1.26071800 & 2.21733300 \\ \mathrm{C} & -3.44587100 & 0.86606200 & -0.54443200 \\ \mathrm{H} & -3.28871000 & 1.27406800 & -1.54785600 \\ \mathrm{H} & -4.36663900 & 0.27155100 & -0.56087500 \\ \mathrm{H} & -3.59808300 & 1.70432800 & 0.14332000\end{array}$

$E[\mathrm{M} 06-2 \mathrm{X} / 6-311++\mathrm{G}(\mathrm{d}, \mathrm{p})]=-1183.16217804$ Hartrees $\Delta G[\mathrm{M} 06-2 \mathrm{X} / 6-31 \mathrm{G}(\mathrm{d})]=0.183784$ Hartrees

TS-A (Brook-type Rearrangement)

$\begin{array}{lrrr}\text { (gas) } & & & \\ \mathrm{Si} & 0.01399600 & -0.07450800 & -0.66679300 \\ \mathrm{Si} & -0.07064600 & 2.21320600 & 0.12959500 \\ \mathrm{Si} & -1.92201200 & -1.23293600 & 0.01055400 \\ \mathrm{Si} & 2.01901100 & -1.10200700 & -0.00664200 \\ \mathrm{O} & -0.06849200 & 0.91759800 & -1.93489600 \\ \mathrm{C} & -3.38353800 & -0.68891800 & -1.04914300 \\ \mathrm{H} & -4.29988100 & -1.20880600 & -0.74840700 \\ \mathrm{H} & -3.55374900 & 0.38802900 & -0.95513900 \\ \mathrm{H} & -3.19865300 & -0.90192000 & -2.10622600 \\ \mathrm{C} & -1.63886000 & -3.09650100 & -0.16732700 \\ \mathrm{H} & -0.79613600 & -3.42925800 & 0.44926900 \\ \mathrm{H} & -2.52650600 & -3.65284500 & 0.15474500 \\ \mathrm{H} & -1.42617900 & -3.37420700 & -1.20481200 \\ \mathrm{C} & -2.26357000 & -0.86204300 & 1.83555600 \\ \mathrm{H} & -2.50967300 & 0.19380900 & 1.99211500 \\ \mathrm{H} & -3.10985300 & -1.45820700 & 2.19565600 \\ \mathrm{H} & -1.39568500 & -1.10173700 & 2.46001100 \\ \mathrm{C} & 2.38445900 & -2.65383900 & -1.02272200 \\ \mathrm{H} & 3.29366300 & -3.14354200 & -0.65558600 \\ \mathrm{H} & 1.56238400 & -3.37368600 & -0.95153600 \\ \mathrm{H} & 2.53342900 & -2.41511900 & -2.08006900 \\ \mathrm{C} & 3.46555500 & 0.10478900 & -0.12652800 \\ \mathrm{H} & 3.34623200 & 0.93350900 & 0.58021600 \\ \mathrm{H} & 4.41088100 & -0.39878700 & 0.10492400 \\ \mathrm{C} & 1.75386700 & -1.60253700 & 1.80067400 \\ \mathrm{H} & 0.94476500 & -2.33544000 & 1.89916500 \\ \mathrm{H} & 2.66227300 & -2.05615600 & 2.21296300 \\ \mathrm{H} & 1.49970000 & -0.73709900 & 2.42260700\end{array}$




$\begin{array}{lrrr}\mathrm{C} & 0.31912600 & 2.18014600 & 1.99071600 \\ \mathrm{H} & 0.19868400 & 3.18775000 & 2.40900300 \\ \mathrm{H} & -0.34644700 & 1.50363700 & 2.53631400 \\ \mathrm{H} & 1.35246000 & 1.86492700 & 2.17204100 \\ \mathrm{C} & 1.19442400 & 3.30119200 & -0.72471500 \\ \mathrm{H} & 1.21378000 & 4.29763700 & -0.26832000 \\ \mathrm{H} & 2.19931000 & 2.87453200 & -0.64657500 \\ \mathrm{H} & 0.94900400 & 3.39177900 & -1.78456200 \\ \mathrm{H} & 3.54321900 & 0.52832400 & -1.13283800 \\ \mathrm{C} & -1.83080600 & 2.81679400 & -0.12947800 \\ \mathrm{H} & -2.54759700 & 2.24350400 & 0.46850800 \\ \mathrm{H} & -1.91861400 & 3.86946800 & 0.16365700 \\ \mathrm{H} & -2.10170900 & 2.72205500 & -1.18413700\end{array}$

$E[\mathrm{M} 06-2 \mathrm{X} / 6-311++\mathrm{G}(\mathrm{d}, \mathrm{p})]=-1592.34702263$ Hartrees $\Delta G[\mathrm{M} 06-2 \mathrm{X} / 6-31 \mathrm{G}(\mathrm{d})]=0.284636$ Hartrees Imaginary Frequency $=-158.53 \mathrm{~cm}^{-1}$

$\begin{array}{lrrr}\text { (MeCN) } & & & \\ \mathrm{Si} & -0.02521200 & -0.08826900 & -0.66522200 \\ \mathrm{Si} & 0.77355200 & 2.07039600 & 0.11317200 \\ \mathrm{Si} & -2.25747300 & -0.41966400 & 0.01425600 \\ \mathrm{Si} & 1.46106000 & -1.78406300 & -0.00399800 \\ \mathrm{O} & 0.28188900 & 0.89420200 & -1.91300800 \\ \mathrm{C} & -3.40066900 & 0.64070200 & -1.04549100 \\ \mathrm{H} & -4.44049100 & 0.53321400 & -0.71369200 \\ \mathrm{H} & -3.13588900 & 1.70186500 & -0.98469700 \\ \mathrm{H} & -3.35049800 & 0.34286200 & -2.09848400 \\ \mathrm{C} & -2.71601700 & -2.24313900 & -0.17254000 \\ \mathrm{H} & -2.07409600 & -2.88247300 & 0.44465700 \\ \mathrm{H} & -3.75211500 & -2.40569400 & 0.15000400 \\ \mathrm{H} & -2.63261800 & -2.57923800 & -1.21190900 \\ \mathrm{C} & -2.41867900 & 0.05852200 & 1.83359400 \\ \mathrm{H} & -2.22414100 & 1.12541000 & 1.99085000 \\ \mathrm{H} & -3.43436200 & -0.15285800 & 2.19057000 \\ \mathrm{H} & -1.72090500 & -0.51073400 & 2.45857700 \\ \mathrm{C} & 1.28355900 & -3.31334700 & -1.09622900 \\ \mathrm{H} & 1.92836300 & -4.12165900 & -0.73040400 \\ \mathrm{H} & 0.25059300 & -3.67939600 & -1.09763600 \\ \mathrm{H} & 1.56599000 & -3.09852500 & -2.13240400 \\ \mathrm{C} & 3.24545300 & -1.17377100 & -0.03201400 \\ \mathrm{H} & 3.38989700 & -0.33532900 & 0.65877300 \\ \mathrm{H} & 3.92645500 & -1.97838400 & 0.27165000 \\ \mathrm{C} & 0.95597400 & -2.20600300 & 1.76661600 \\ \mathrm{H} & -0.06996200 & -2.58986100 & 1.81130400 \\ \mathrm{H} & 1.61661100 & -2.97866500 & 2.17902400 \\ \mathrm{H} & 1.01961100 & -1.32968800 & 2.42221000 \\ \mathrm{C} & 1.12841000 & 1.86806700 & 1.96776500 \\ \mathrm{H} & 1.42760800 & 2.84154600 & 2.38055600 \\ \mathrm{H} & 0.24891100 & 1.52030800 & 2.51975000 \\ \mathrm{H} & 1.94911900 & 1.16379000 & 2.14434600 \\ \mathrm{C} & 2.36661000 & 2.60711100 & -0.71633700 \\ \mathrm{H} & 2.80577300 & 3.44920900 & -0.16748400 \\ \mathrm{H} & 3.10175900 & 1.79514400 & -0.72518000 \\ \mathrm{H} & 2.18653000 & 2.91447400 & -1.74943300 \\ \mathrm{H} & 3.54234300 & -0.84505800 & -1.03391200\end{array}$




$\begin{array}{lrrr}\mathrm{C} & -0.61470300 & 3.31365200 & -0.11095800 \\ \mathrm{H} & -1.50930300 & 3.02717500 & 0.45312500 \\ \mathrm{H} & -0.29238900 & 4.29559700 & 0.25838600 \\ \mathrm{H} & -0.88451000 & 3.41497600 & -1.16581200\end{array}$

$E[\mathrm{M} 06-2 \mathrm{X} / 6-311++\mathrm{G}(\mathrm{d}, \mathrm{p})]=-1592.35884217$ Hartrees $\Delta G[\mathrm{M} 06-2 \mathrm{X} / 6-31 \mathrm{G}(\mathrm{d})]=0.285951$ Hartrees Imaginary Frequency $=-186.30 \mathrm{~cm}^{-1}$

\section{TS-B (Beta Scission)}

$\begin{array}{lrrr}\mathrm{Si} & -0.49937800 & 0.01163700 & -0.79643400 \\ \mathrm{Si} & 2.90131200 & -0.59569400 & -0.17942100 \\ \mathrm{Si} & -0.90045800 & 2.16560200 & 0.08533700 \\ \mathrm{Si} & -1.85789800 & -1.75951800 & -0.03941300 \\ \mathrm{O} & 0.74465000 & -0.29872800 & -1.67624500 \\ \mathrm{C} & -0.02057900 & 2.31158400 & 1.75198900 \\ \mathrm{H} & -0.21928800 & 3.29419700 & 2.19499200 \\ \mathrm{H} & -0.37242600 & 1.54854300 & 2.45494200 \\ \mathrm{H} & 1.06335100 & 2.19890200 & 1.64641300 \\ \mathrm{C} & -0.32733900 & 3.51436100 & -1.09772100 \\ \mathrm{H} & -0.86858800 & 3.46192700 & -2.04718400 \\ \mathrm{H} & -0.50573600 & 4.50266500 & -0.65932300 \\ \mathrm{H} & 0.74065300 & 3.42735800 & -1.31700300 \\ \mathrm{C} & -2.76705400 & 2.29756200 & 0.36616000 \\ \mathrm{H} & -3.13095200 & 1.51173500 & 1.03769100 \\ \mathrm{H} & -3.01579800 & 3.26181200 & 0.82347600 \\ \mathrm{H} & -3.32373000 & 2.22230300 & -0.57383400 \\ \mathrm{C} & -3.58535400 & -1.63431900 & -0.79482200 \\ \mathrm{H} & -4.21897100 & -2.44764500 & -0.42391800 \\ \mathrm{H} & -4.06818100 & -0.68777600 & -0.52992300 \\ \mathrm{H} & -3.55316600 & -1.70577300 & -1.88618300 \\ \mathrm{C} & -1.00221600 & -3.36145200 & -0.52945500 \\ \mathrm{H} & -0.00044800 & -3.40979800 & -0.09014100 \\ \mathrm{H} & -1.56909300 & -4.23622900 & -0.19291500 \\ \mathrm{C} & -1.99916700 & -1.61919600 & 1.84208300 \\ \mathrm{H} & -2.39387800 & -0.64419200 & 2.14894700 \\ \mathrm{H} & -2.67900000 & -2.38684900 & 2.22889400 \\ \mathrm{H} & -1.02706200 & -1.75819100 & 2.32582100 \\ \mathrm{C} & 1.88447600 & -0.91881900 & 1.39956900 \\ \mathrm{H} & 2.39779800 & -0.49167700 & 2.27061100 \\ \mathrm{H} & 0.88175300 & -0.47039400 & 1.38580700 \\ \mathrm{H} & 1.76436400 & -1.99320700 & 1.57851100 \\ \mathrm{H} & 4.60027200 & -1.39271000 & 0.13751600 \\ \mathrm{H} & 5.08455400 & -0.94390900 & 1.01453300 \\ \mathrm{H} & 4.50622100 & -2.46801200 & 0.31835200 \\ \mathrm{H} & 5.26756900 & -1.25669300 & -0.71899300 \\ \mathrm{H} & -0.88483200 & -3.42053700 & -1.61549800 \\ \mathrm{H} & 3.14632200 & 1.27085700 & -0.36252300 \\ \mathrm{H} & & & \\ \mathrm{H} & 3.5714900 & 1.75692300 & -0.56990000 \\ \mathrm{H} & -1579700 & 1.49828300 & -1.19785000\end{array}$

$E[\mathrm{M} 06-2 \mathrm{X} / 6-311++\mathrm{G}(\mathrm{d}, \mathrm{p})]=-1592.31180423$ Hartrees $\Delta G[\mathrm{M} 06-2 \mathrm{X} / 6-31 \mathrm{G}(\mathrm{d})]=0.281720$ Hartrees 
Imaginary Frequency $=-149.40 \mathrm{~cm}^{-1}$

$\begin{array}{lrrr}(\mathrm{MeCN}) & & & \\ \mathrm{Si} & -0.46361400 & 0.01033500 & -0.77736900 \\ \mathrm{Si} & 2.86219800 & -0.53393000 & -0.17460700 \\ \mathrm{Si} & -0.94976300 & 2.15516900 & 0.08132500 \\ \mathrm{Si} & -1.79923400 & -1.78809200 & -0.03726400 \\ \mathrm{O} & 0.81217700 & -0.27557500 & -1.64138300 \\ \mathrm{C} & -0.10198300 & 2.33901300 & 1.75684700 \\ \mathrm{H} & -0.37846200 & 3.30155400 & 2.20478800 \\ \mathrm{H} & -0.41220600 & 1.54635000 & 2.44740900 \\ \mathrm{H} & 0.98992900 & 2.30770200 & 1.67102700 \\ \mathrm{C} & -0.40358700 & 3.50670400 & -1.10932100 \\ \mathrm{H} & -0.91713800 & 3.41594700 & -2.07231400 \\ \mathrm{H} & -0.64072200 & 4.49263500 & -0.69178300 \\ \mathrm{H} & 0.67484700 & 3.47103500 & -1.29575800 \\ \mathrm{C} & -2.81957100 & 2.19967100 & 0.32249000 \\ \mathrm{H} & -3.15638000 & 1.40751100 & 1.00123600 \\ \mathrm{H} & -3.11905700 & 3.15947600 & 0.76073200 \\ \mathrm{H} & -3.35324000 & 2.08525100 & -0.62731100 \\ \mathrm{C} & -3.49718000 & -1.68777600 & -0.84856400 \\ \mathrm{H} & -4.12149500 & -2.52862300 & -0.52347200 \\ \mathrm{H} & -4.01239000 & -0.76111400 & -0.57177200 \\ \mathrm{H} & -3.42781900 & -1.72313400 & -1.94080900 \\ \mathrm{C} & -0.91108000 & -3.38065300 & -0.50164800 \\ \mathrm{H} & 0.10224000 & -3.40515100 & -0.08490200 \\ \mathrm{H} & -1.45410000 & -4.25432700 & -0.12239100 \\ \mathrm{C} & -1.98699200 & -1.63365400 & 1.83368600 \\ \mathrm{H} & -2.44395600 & -0.67744100 & 2.11321700 \\ \mathrm{H} & -2.63693900 & -2.43366800 & 2.20949400 \\ \mathrm{H} & -1.02385200 & -1.71540300 & 2.34922900 \\ \mathrm{C} & 1.85834500 & -0.86069900 & 1.40483700 \\ \mathrm{H} & 2.38019200 & -0.42259800 & 2.26631900 \\ \mathrm{H} & 0.84894400 & -0.42723500 & 1.41399200 \\ \mathrm{H} & 1.75932000 & -1.93610000 & 1.59343000 \\ \mathrm{C} & 4.54128800 & -1.38520500 & 0.11491300 \\ \mathrm{H} & 5.03721000 & -0.97591300 & 1.00619500 \\ \mathrm{H} & 4.42108700 & -2.46364900 & 0.26600200 \\ \mathrm{H} & 5.21580100 & -1.24070200 & -0.73607100 \\ \mathrm{H} & -0.82787600 & -3.47986600 & -1.58920900 \\ \mathrm{C} & 3.18032000 & 1.32325300 & -0.32740100 \\ \mathrm{H} & 2.24527500 & 1.87114200 & -0.48519100 \\ \mathrm{H} & 3.66159900 & 1.71396900 & 0.57886000 \\ \mathrm{H} & 3.84019000 & 1.54428600 & -1.17410000\end{array}$

$E[\mathrm{M} 06-2 \mathrm{X} / 6-311++\mathrm{G}(\mathrm{d}, \mathrm{p})]=-1592.32659044$ Hartrees $\Delta G[\mathrm{M} 06-2 \mathrm{X} / 6-31 \mathrm{G}(\mathrm{d})]=0.282648$ Hartrees Imaginary Frequency $=-220.05 \mathrm{~cm}^{-1}$

$\begin{array}{lrrr}\text { (water) } & & & \\ \mathrm{Si} & -0.45692400 & 0.01147100 & -0.80150000 \\ \mathrm{Si} & 2.84456000 & -0.48505900 & -0.16254500 \\ \mathrm{Si} & -0.97157500 & 2.14084400 & 0.07297200 \\ \mathrm{Si} & -1.75232600 & -1.80135100 & -0.03311900 \\ \mathrm{O} & 0.82986700 & -0.26235100 & -1.67053600 \\ \mathrm{C} & -0.16966000 & 2.29288600 & 1.77294200\end{array}$




$\begin{array}{lrrr}\mathrm{H} & -0.47086900 & 3.23995400 & 2.23674500 \\ \mathrm{H} & -0.48791800 & 1.47918700 & 2.43470300 \\ \mathrm{H} & 0.92430100 & 2.27638000 & 1.71565100 \\ \mathrm{C} & -0.40907100 & 3.51915600 & -1.07695400 \\ \mathrm{H} & -0.89271700 & 3.43721000 & -2.05560900 \\ \mathrm{H} & -0.67286800 & 4.49350400 & -0.64959200 \\ \mathrm{H} & 0.67450500 & 3.50095300 & -1.23189600 \\ \mathrm{C} & -2.84652100 & 2.14604300 & 0.26641900 \\ \mathrm{H} & -3.18525100 & 1.32125000 & 0.90410100 \\ \mathrm{H} & -3.17217000 & 3.08188000 & 0.73577400 \\ \mathrm{H} & -3.35382400 & 2.06078700 & -0.70041500 \\ \mathrm{C} & -3.44594900 & -1.74513900 & -0.85536300 \\ \mathrm{H} & -4.08756600 & -2.53631300 & -0.45033900 \\ \mathrm{H} & -3.94126500 & -0.78488100 & -0.67398300 \\ \mathrm{H} & -3.37427800 & -1.88985200 & -1.93807000 \\ \mathrm{C} & -0.82447600 & -3.38151800 & -0.45873400 \\ \mathrm{H} & 0.18964100 & -3.36691700 & -0.04378000 \\ \mathrm{H} & -1.34302600 & -4.25935500 & -0.05682300 \\ \mathrm{C} & -1.95456500 & -1.59586200 & 1.83052400 \\ \mathrm{H} & -2.41669300 & -0.63313500 & 2.07738000 \\ \mathrm{H} & -2.60569400 & -2.38655700 & 2.22258100 \\ \mathrm{H} & -0.99550500 & -1.66002900 & 2.35501400 \\ \mathrm{C} & 1.81245500 & -0.87976400 & 1.37788500 \\ \mathrm{H} & 2.35208900 & -0.53200900 & 2.26855200 \\ \mathrm{H} & 0.83210900 & -0.38577000 & 1.41582800 \\ \mathrm{H} & 1.64937800 & -1.95773300 & 1.48921300 \\ \mathrm{C} & 4.51668100 & -1.35325100 & 0.07913900 \\ \mathrm{H} & 5.00763200 & -0.99774100 & 0.99511100 \\ \mathrm{H} & 4.39443800 & -2.43803500 & 0.16341300 \\ \mathrm{H} & 5.19196800 & -1.15598100 & -0.75990000 \\ \mathrm{H} & -0.74109800 & -3.50491200 & -1.54350500 \\ \mathrm{C} & 3.14673900 & 1.37696800 & -0.24168500 \\ \mathrm{H} & 2.21237200 & 1.92748900 & -0.39532400 \\ \mathrm{H} & 3.60529200 & 1.73635500 & 0.68842500 \\ \mathrm{H} & 3.82198900 & 1.63330200 & -1.06532000\end{array}$

$E[\mathrm{M} 06-2 \mathrm{X} / 6-311++\mathrm{G}(\mathrm{d}, \mathrm{p})]=-1592.31902193$ Hartrees $\Delta G[\mathrm{M} 06-2 \mathrm{X} / 6-31 \mathrm{G}(\mathrm{d})]=0.284617$ Hartrees Imaginary Frequency $=-285.60 \mathrm{~cm}^{-1}$

TS-C (N-F Abstraction by Silyl Radical)

$\begin{array}{lrrr}\text { (gas) } & & & \\ \mathrm{C} & 0.62668000 & 3.06780800 & -0.20050100 \\ \mathrm{C} & 1.43679600 & 3.88364600 & 0.58282200 \\ \mathrm{H} & 2.45861400 & 4.08743800 & 0.27897400 \\ \mathrm{C} & 0.89623300 & 4.40867300 & 1.75323600 \\ \mathrm{H} & 1.50364500 & 5.04883700 & 2.38425200 \\ \mathrm{C} & -0.41713200 & 4.11276000 & 2.11427900 \\ \mathrm{H} & -0.82700000 & 4.52373900 & 3.03177400 \\ \mathrm{C} & -1.20826300 & 3.28914500 & 1.31339100 \\ \mathrm{H} & -2.22972900 & 3.05359600 & 1.59533900 \\ \mathrm{C} & -0.68390900 & 2.75201900 & 0.14480400 \\ \mathrm{H} & -1.27151200 & 2.09859800 & -0.49015900 \\ \mathrm{C} & 3.40563500 & -1.03842000 & 0.00510900\end{array}$




\begin{tabular}{|c|c|c|c|}
\hline $\mathrm{C}$ & 2.59140100 & -2.15217500 & 0.19480000 \\
\hline $\mathrm{H}$ & 1.56659700 & -2.02533400 & 0.53332900 \\
\hline $\mathrm{C}$ & 3.12660800 & -3.41078900 & -0.05373800 \\
\hline $\mathrm{H}$ & 2.51271200 & -4.29559100 & 0.08337600 \\
\hline $\mathrm{C}$ & 4.45098200 & -3.53541100 & -0.47352000 \\
\hline $\mathrm{H}$ & 4.86453500 & -4.52158000 & -0.66001400 \\
\hline $\mathrm{C}$ & 5.24787800 & -2.40763900 & -0.65401900 \\
\hline $\mathrm{H}$ & 6.27730600 & -2.51328400 & -0.97986500 \\
\hline $\mathrm{C}$ & 4.72511900 & -1.13900000 & -0.41982700 \\
\hline $\mathrm{H}$ & 5.31752600 & -0.24003100 & -0.55601100 \\
\hline $\mathrm{N}$ & 1.79440600 & 0.73361200 & -1.16305700 \\
\hline $\mathrm{O}$ & 2.51482900 & 3.00139500 & -2.05133600 \\
\hline $\mathrm{O}$ & 0.21954500 & 2.07289400 & -2.59546000 \\
\hline $\mathrm{O}$ & 1.83873600 & 0.51070100 & 1.44350400 \\
\hline $\mathrm{O}$ & 3.78303700 & 1.56833400 & 0.22023100 \\
\hline $\mathrm{F}$ & 0.49000500 & 0.04833800 & -0.76904100 \\
\hline $\mathrm{S}$ & 1.29332100 & 2.33552900 & -1.66187100 \\
\hline $\mathrm{S}$ & 2.73398800 & 0.57079200 & 0.30252400 \\
\hline $\mathrm{Si}$ & -1.49405800 & -0.91581600 & 0.37980000 \\
\hline $\mathrm{Si}$ & -1.46083000 & -2.81672700 & -1.00100800 \\
\hline $\mathrm{Si}$ & -1.17441400 & -1.15530000 & 2.68684600 \\
\hline $\mathrm{C}$ & -1.02850200 & 0.56354500 & 3.44360800 \\
\hline $\mathrm{H}$ & -1.92837700 & 1.15498700 & 3.24728900 \\
\hline $\mathrm{H}$ & -0.89639700 & 0.49195800 & 4.52940000 \\
\hline $\mathrm{H}$ & -0.16808000 & 1.09161800 & 3.02009300 \\
\hline $\mathrm{C}$ & -2.69180500 & -2.03577200 & 3.40078400 \\
\hline $\mathrm{H}$ & -2.77231200 & -3.06095300 & 3.02377900 \\
\hline $\mathrm{H}$ & -2.63472800 & -2.08214400 & 4.49469200 \\
\hline $\mathrm{H}$ & -3.61097000 & -1.50535500 & 3.13157200 \\
\hline $\mathrm{C}$ & 0.37342700 & -2.14954200 & 3.11376300 \\
\hline $\mathrm{H}$ & 1.27582900 & -1.60369200 & 2.82211100 \\
\hline $\mathrm{H}$ & 0.40773600 & -2.29565800 & 4.19988800 \\
\hline $\mathrm{H}$ & 0.38809000 & -3.14079500 & 2.64907800 \\
\hline $\mathrm{C}$ & -0.72469700 & -4.19683900 & 0.07088800 \\
\hline $\mathrm{H}$ & -1.38840400 & -4.45824000 & 0.90227200 \\
\hline $\mathrm{H}$ & -0.56507600 & -5.09867400 & -0.53189400 \\
\hline $\mathrm{H}$ & 0.24148800 & -3.90778200 & 0.49730400 \\
\hline $\mathrm{C}$ & -0.31078800 & -2.53871800 & -2.47045800 \\
\hline $\mathrm{H}$ & -0.30994600 & -3.41487100 & -3.12916400 \\
\hline $\mathrm{H}$ & -0.59906900 & -1.66384700 & -3.06078600 \\
\hline $\mathrm{H}$ & 0.71477000 & -2.37041400 & -2.12471600 \\
\hline $\mathrm{C}$ & -3.15446300 & -3.41206000 & -1.59922900 \\
\hline $\mathrm{H}$ & -3.03281700 & -4.35479100 & -2.14590700 \\
\hline $\mathrm{H}$ & -3.82766400 & -3.59722200 & -0.75566700 \\
\hline $\mathrm{H}$ & -3.63992100 & -2.69920700 & -2.27238500 \\
\hline $\mathrm{O}$ & -2.74555500 & 0.17622600 & 0.18164000 \\
\hline $\mathrm{Si}$ & -3.79020200 & 0.62276800 & -1.04848900 \\
\hline $\mathrm{C}$ & -4.21956700 & 2.43001900 & -0.79379900 \\
\hline $\mathrm{H}$ & -4.99402900 & 2.73924400 & -1.50466800 \\
\hline $\mathrm{H}$ & -4.61219300 & 2.59638100 & 0.21520500 \\
\hline $\mathrm{H}$ & -3.35822500 & 3.08993300 & -0.93776400 \\
\hline $\mathrm{C}$ & -5.35253600 & -0.40386200 & -0.90674400 \\
\hline $\mathrm{H}$ & -6.03147500 & -0.20459500 & -1.74319700 \\
\hline $\mathrm{H}$ & -5.13130400 & -1.47548000 & -0.90151300 \\
\hline $\mathrm{H}$ & -5.88457000 & -0.16825200 & 0.02074800 \\
\hline $\mathrm{C}$ & -2.92418000 & 0.37156300 & -2.69172200 \\
\hline
\end{tabular}




$\begin{array}{lrrr}\mathrm{H} & -1.92110700 & 0.81774700 & -2.67997600 \\ \mathrm{H} & -2.81582800 & -0.68955700 & -2.94166700 \\ \mathrm{H} & -3.48711900 & 0.84277100 & -3.50509900\end{array}$

$E[\mathrm{M} 06-2 \mathrm{X} / 6-311++\mathrm{G}(\mathrm{d}, \mathrm{p})]=-3307.25879783$ Hartrees $\Delta G[\mathrm{M} 06-2 \mathrm{X} / 6-31 \mathrm{G}(\mathrm{d})]=0.475626$ Hartrees Imaginary Frequency $=-804.90 \mathrm{~cm}^{-1}$

$\begin{array}{lrrr}(\mathrm{MeCN}) & & & \\ \mathrm{C} & 0.59177400 & 3.08849700 & -0.22949300 \\ \mathrm{C} & 1.34452900 & 3.93178700 & 0.58350000 \\ \mathrm{H} & 2.38240800 & 4.14517000 & 0.34784900 \\ \mathrm{C} & 0.72295200 & 4.49284000 & 1.69602100 \\ \mathrm{H} & 1.28406500 & 5.15777300 & 2.34432900 \\ \mathrm{C} & -0.61452900 & 4.20756200 & 1.96988900 \\ \mathrm{H} & -1.09126700 & 4.65341000 & 2.83748600 \\ \mathrm{C} & -1.34730300 & 3.35592900 & 1.14124300 \\ \mathrm{H} & -2.38811900 & 3.13618700 & 1.35870600 \\ \mathrm{C} & -0.74231000 & 2.78004400 & 0.03042200 \\ \mathrm{H} & -1.2888000 & 2.11165500 & -0.62703600 \\ \mathrm{C} & 3.43844700 & -1.04041100 & 0.03867700 \\ \mathrm{C} & 2.61807800 & -2.14158400 & 0.27777500 \\ \mathrm{H} & 1.60910600 & -2.00643900 & 0.65774100 \\ \mathrm{C} & 3.12832000 & -3.40980100 & 0.02222800 \\ \mathrm{H} & 2.50898200 & -4.28408400 & 0.19739500 \\ \mathrm{C} & 4.43328100 & -3.55454800 & -0.45086400 \\ \mathrm{H} & 4.82750000 & -4.54790500 & -0.64148400 \\ \mathrm{C} & 5.23603600 & -2.43825900 & -0.67972300 \\ \mathrm{H} & 6.24998000 & -2.55956200 & -1.04621400 \\ \mathrm{C} & 4.73929400 & -1.15995200 & -0.44173500 \\ \mathrm{H} & 5.34474200 & -0.27707300 & -0.61984100 \\ \mathrm{~N} & 1.84072000 & 0.75409100 & -1.12929300 \\ \mathrm{O} & 2.58672400 & 3.02905600 & -1.97522200 \\ \mathrm{O} & 0.34650100 & 2.07933900 & -2.64559800 \\ \mathrm{O} & 1.89836200 & 0.54930100 & 1.47737100 \\ \mathrm{O} & 3.84459500 & 1.57032700 & 0.23987700 \\ \mathrm{~F} & 0.53316800 & 0.08775300 & -0.74750800 \\ \mathrm{~S} & 1.35227600 & 2.3500100 & -1.63697900 \\ \mathrm{~S} & 2.79229300 & 0.57436100 & 0.33349800 \\ \mathrm{Si} & -1.51700800 & -0.93599200 & 0.39520000 \\ \mathrm{Si} & -1.37935800 & -2.87911700 & -0.92725500 \\ \mathrm{Si} & -1.23083000 & -1.04637900 & 2.71974800 \\ \mathrm{C} & -1.03778700 & 0.70436200 & 3.39371200 \\ \mathrm{H} & -1.91386900 & 1.32321200 & 3.17276700 \\ \mathrm{H} & -0.91683000 & 0.67164000 & 4.48399400 \\ \mathrm{H} & -0.15283200 & 1.18812200 & 2.96656300 \\ \mathrm{C} & -2.78972600 & -1.82376200 & 3.45808100 \\ \mathrm{H} & -2.91745200 & -2.85907900 & 3.12178600 \\ \mathrm{H} & -2.73800200 & -1.82745500 & 4.55418700 \\ \mathrm{H} & -3.68472200 & -1.26324900 & 3.16508200 \\ \mathrm{C} & 0.27353400 & -2.05890000 & 3.23912200 \\ \mathrm{H} & 1.20332700 & -1.59233100 & 2.89784100 \\ \mathrm{H} & 0.30444100 & -2.09851100 & 4.33568200 \\ \mathrm{H} & 0.24052800 & -3.08963900 & 2.87125200 \\ \mathrm{H} & -0.66256600 & -4.21397800 & 0.20414000 \\ & -1.38930800 & -4.51434300 & 0.96810300\end{array}$




$\begin{array}{lrrr}\mathrm{H} & -0.40326200 & -5.10454400 & -0.38222000 \\ \mathrm{H} & 0.24390700 & -3.87813000 & 0.71778300 \\ \mathrm{C} & -0.18888400 & -2.59955900 & -2.36459300 \\ \mathrm{H} & -0.10280800 & -3.51576600 & -2.96225400 \\ \mathrm{H} & -0.52490100 & -1.79482900 & -3.02763200 \\ \mathrm{H} & 0.81179200 & -2.33725400 & -2.00340000 \\ \mathrm{C} & -3.03144800 & -3.50602900 & -1.59650300 \\ \mathrm{H} & -2.86265900 & -4.46052200 & -2.11189600 \\ \mathrm{H} & -3.75100600 & -3.68497300 & -0.79030500 \\ \mathrm{H} & -3.48438900 & -2.81814000 & -2.31760300 \\ \mathrm{O} & -2.81831600 & 0.08580600 & 0.14293100 \\ \mathrm{Si} & -3.82309500 & 0.49607100 & -1.13540900 \\ \mathrm{C} & -4.33389700 & 2.28204600 & -0.90230000 \\ \mathrm{H} & -5.09268800 & 2.55083200 & -1.64765800 \\ \mathrm{H} & -4.77466600 & 2.44051300 & 0.08850000 \\ \mathrm{H} & -3.49567900 & 2.97764400 & -1.01990400 \\ \mathrm{C} & -5.34510500 & -0.59257500 & -1.08734000 \\ \mathrm{H} & -5.97636500 & -0.40949700 & -1.96521900 \\ \mathrm{H} & -5.08825800 & -1.65671500 & -1.07407200 \\ \mathrm{H} & -5.94591300 & -0.37993400 & -0.19561400 \\ \mathrm{C} & -2.86447100 & 0.29241800 & -2.73371900 \\ \mathrm{H} & -1.87212800 & 0.75577300 & -2.65561600 \\ \mathrm{H} & -2.72640000 & -0.76006600 & -3.00606000 \\ \mathrm{H} & -3.39320200 & 0.77819000 & -3.56279900\end{array}$

$E[\mathrm{M} 06-2 \mathrm{X} / 6-311++\mathrm{G}(\mathrm{d}, \mathrm{p})]=-3307.28893608$ Hartrees $\Delta G[\mathrm{M} 06-2 \mathrm{X} / 6-31 \mathrm{G}(\mathrm{d})]=0.475460$ Hartrees Imaginary Frequency $=-886.04 \mathrm{~cm}^{-1}$

$\begin{array}{lrrr}\text { (water) } & & & \\ \mathrm{C} & 0.61588600 & 3.06631700 & -0.16644500 \\ \mathrm{C} & 1.34124900 & 3.78781100 & 0.77888300 \\ \mathrm{H} & 2.40064200 & 3.98067700 & 0.64039600 \\ \mathrm{C} & 0.66316900 & 4.25729200 & 1.89972400 \\ \mathrm{H} & 1.19993400 & 4.82517700 & 2.65180600 \\ \mathrm{C} & -0.69931000 & 4.00150400 & 2.05207800 \\ \mathrm{H} & -1.21871800 & 4.36926200 & 2.93156600 \\ \mathrm{C} & -1.40362800 & 3.27645000 & 1.08987300 \\ \mathrm{H} & -2.46422200 & 3.08120100 & 1.21483300 \\ \mathrm{C} & -0.74449500 & 2.79512400 & -0.03445300 \\ \mathrm{H} & -1.26887900 & 2.23389700 & -0.80076600 \\ \mathrm{C} & 3.41889800 & -1.09752700 & 0.04936000 \\ \mathrm{C} & 2.55137300 & -2.14507800 & 0.35448600 \\ \mathrm{H} & 1.57119500 & -1.94889100 & 0.77984900 \\ \mathrm{C} & 2.98084300 & -3.44374500 & 0.10376900 \\ \mathrm{H} & 2.32721300 & -4.27981400 & 0.33034800 \\ \mathrm{C} & 4.24884300 & -3.66872100 & -0.43271200 \\ \mathrm{H} & 4.57739500 & -4.68569000 & -0.62144500 \\ \mathrm{C} & 5.09891700 & -2.60380000 & -0.72730500 \\ \mathrm{H} & 6.08401400 & -2.78757400 & -1.14222300 \\ \mathrm{C} & 4.68623700 & -1.29620000 & -0.49326300 \\ \mathrm{H} & 5.33091700 & -0.45377000 & -0.72024400 \\ \mathrm{~N} & 1.93234900 & 0.79148200 & -1.12450400 \\ \mathrm{O} & 2.70425100 & 3.11647600 & -1.79995900 \\ \mathrm{O} & 0.51781800 & 2.19115300 & -2.65061300 \\ \mathrm{O} & 1.99698500 & 0.61074100 & 1.48573600\end{array}$




\begin{tabular}{|c|c|c|c|}
\hline $\mathrm{O}$ & 3.99056400 & 1.48594600 & 0.21920200 \\
\hline $\mathrm{F}$ & 0.61579300 & 0.13356700 & -0.75486900 \\
\hline $\mathrm{S}$ & 1.45637900 & 2.41151600 & -1.56525800 \\
\hline S & 2.87948200 & 0.55375300 & 0.33058500 \\
\hline $\mathrm{Si}$ & -1.50572600 & -0.86944100 & 0.35965900 \\
\hline $\mathrm{Si}$ & -1.41019600 & -2.81500400 & -0.96575300 \\
\hline $\mathrm{Si}$ & -1.32457400 & -1.06200700 & 2.69074600 \\
\hline $\mathrm{C}$ & -1.24453900 & 0.68013100 & 3.40742900 \\
\hline $\mathrm{H}$ & -2.12132000 & 1.27326900 & 3.12655000 \\
\hline $\mathrm{H}$ & -1.20447100 & 0.63526100 & 4.50258100 \\
\hline $\mathrm{H}$ & -0.35039600 & 1.20606600 & 3.05429200 \\
\hline $\mathrm{C}$ & -2.88547400 & -1.93117900 & 3.30322100 \\
\hline $\mathrm{H}$ & -2.93549600 & -2.96233100 & 2.93590400 \\
\hline $\mathrm{H}$ & -2.90538700 & -1.96079700 & 4.39957100 \\
\hline $\mathrm{H}$ & -3.78668400 & -1.40926800 & 2.96306400 \\
\hline $\mathrm{C}$ & 0.18931900 & -2.02877400 & 3.26230400 \\
\hline $\mathrm{H}$ & 1.12339800 & -1.52289900 & 2.99767400 \\
\hline $\mathrm{H}$ & 0.15612500 & -2.10978900 & 4.35611200 \\
\hline $\mathrm{H}$ & 0.21783800 & -3.04526700 & 2.85681500 \\
\hline $\mathrm{C}$ & -0.76495600 & -4.14061300 & 0.21746300 \\
\hline $\mathrm{H}$ & -1.52166700 & -4.39218800 & 0.96989300 \\
\hline $\mathrm{H}$ & -0.51790100 & -5.05602500 & -0.33397600 \\
\hline $\mathrm{H}$ & 0.13670100 & -3.81691500 & 0.74673100 \\
\hline $\mathrm{C}$ & -0.17233200 & -2.58283400 & -2.37050000 \\
\hline $\mathrm{H}$ & -0.12788700 & -3.49089200 & -2.98404600 \\
\hline $\mathrm{H}$ & -0.43959900 & -1.74537200 & -3.02383400 \\
\hline $\mathrm{H}$ & 0.83205200 & -2.39494500 & -1.97502700 \\
\hline $\mathrm{C}$ & -3.06207700 & -3.41264300 & -1.65702300 \\
\hline $\mathrm{H}$ & -2.89537600 & -4.36488500 & -2.17663300 \\
\hline $\mathrm{H}$ & -3.78686500 & -3.59287300 & -0.85609400 \\
\hline $\mathrm{H}$ & -3.50809800 & -2.71784900 & -2.37525300 \\
\hline $\mathrm{O}$ & -2.77018800 & 0.20779800 & 0.11552800 \\
\hline $\mathrm{Si}$ & -3.76166300 & 0.56557300 & -1.19759900 \\
\hline $\mathrm{C}$ & -4.28377200 & 2.35487900 & -1.03717600 \\
\hline $\mathrm{H}$ & -5.06435300 & 2.57490900 & -1.77558700 \\
\hline $\mathrm{H}$ & -4.70332000 & 2.55600400 & -0.04525100 \\
\hline $\mathrm{H}$ & -3.45945100 & 3.05504300 & -1.21033900 \\
\hline $\mathrm{C}$ & -5.27565300 & -0.53085700 & -1.11907000 \\
\hline $\mathrm{H}$ & -5.83107100 & -0.49559500 & -2.06342600 \\
\hline $\mathrm{H}$ & -5.01374300 & -1.57519600 & -0.92150800 \\
\hline $\mathrm{H}$ & -5.95106700 & -0.19887400 & -0.32260600 \\
\hline $\mathrm{C}$ & -2.77533500 & 0.30797600 & -2.77119700 \\
\hline $\mathrm{H}$ & -1.77750900 & 0.75683100 & -2.68442700 \\
\hline $\mathrm{H}$ & -2.64868200 & -0.75068500 & -3.02191800 \\
\hline $\mathrm{H}$ & -3.28180200 & 0.78630200 & -3.61780900 \\
\hline
\end{tabular}

$E[\mathrm{M} 06-2 \mathrm{X} / 6-311++\mathrm{G}(\mathrm{d}, \mathrm{p})]=-3307.27698452$ Hartrees $\Delta G[\mathrm{M} 06-2 \mathrm{X} / 6-31 \mathrm{G}(\mathrm{d})]=0.477244$ Hartrees Imaginary Frequency $=-932.71 \mathrm{~cm}^{-1}$

TS-D (C-Br Abstraction by Silyl Radical)

$\begin{array}{lrrr}\text { (gas) } & & & \\ \mathrm{Si} & -1.13318900 & 0.17392500 & -0.13612900 \\ \mathrm{Si} & 0.46855200 & 2.74027400 & -0.67218700\end{array}$




\begin{tabular}{|c|c|c|c|}
\hline $\mathrm{Si}$ & -2.02562300 & -0.10083100 & 1.99751800 \\
\hline $\mathrm{Si}$ & -1.54607600 & -1.27118800 & -1.91695700 \\
\hline $\mathrm{O}$ & -0.87321300 & 1.73979100 & -0.66038200 \\
\hline $\mathrm{C}$ & -0.78670700 & 0.50495000 & 3.28703100 \\
\hline $\mathrm{H}$ & -1.10715300 & 0.21674000 & 4.29454500 \\
\hline $\mathrm{H}$ & 0.19477600 & 0.06057000 & 3.09222100 \\
\hline $\mathrm{H}$ & -0.67671700 & 1.59341000 & 3.26383500 \\
\hline $\mathrm{C}$ & -3.69268700 & 0.74788600 & 2.26317500 \\
\hline $\mathrm{H}$ & -4.44182000 & 0.37332100 & 1.55865100 \\
\hline $\mathrm{H}$ & -4.06071000 & 0.56699300 & 3.27958100 \\
\hline $\mathrm{H}$ & -3.60927600 & 1.82979300 & 2.12161200 \\
\hline $\mathrm{C}$ & -2.21619200 & -1.97500700 & 2.15835700 \\
\hline $\mathrm{H}$ & -1.27580700 & -2.47847800 & 1.90799700 \\
\hline $\mathrm{H}$ & -2.48610200 & -2.25069800 & 3.18383400 \\
\hline $\mathrm{H}$ & -2.99641600 & -2.35718700 & 1.49141600 \\
\hline $\mathrm{C}$ & -3.28064700 & -1.10988500 & -2.65073900 \\
\hline $\mathrm{H}$ & -3.40481700 & -1.78422100 & -3.50587200 \\
\hline $\mathrm{H}$ & -4.04373900 & -1.36301100 & -1.90742900 \\
\hline $\mathrm{H}$ & -3.47077700 & -0.08848200 & -2.99423300 \\
\hline $\mathrm{C}$ & -0.24979500 & -0.83314500 & -3.21834100 \\
\hline $\mathrm{H}$ & 0.75519200 & -0.94448200 & -2.79628600 \\
\hline $\mathrm{H}$ & -0.33090600 & -1.48603400 & -4.09442800 \\
\hline $\mathrm{C}$ & -1.27015600 & -3.04223100 & -1.32133000 \\
\hline $\mathrm{H}$ & -2.05725900 & -3.36894500 & -0.63468200 \\
\hline $\mathrm{H}$ & -1.25669900 & -3.73250700 & -2.17223500 \\
\hline $\mathrm{H}$ & -0.31057100 & -3.11677700 & -0.79997200 \\
\hline $\mathrm{C}$ & 1.77808000 & 2.02925000 & -1.81261100 \\
\hline $\mathrm{H}$ & 2.67456700 & 2.65953700 & -1.81849500 \\
\hline $\mathrm{H}$ & 2.06183900 & 1.03236600 & -1.45930100 \\
\hline $\mathrm{H}$ & 1.41931400 & 1.93900900 & -2.84274600 \\
\hline $\mathrm{C}$ & -0.11681700 & 4.41038700 & -1.28309400 \\
\hline $\mathrm{H}$ & 0.70988200 & 5.12795600 & -1.31874200 \\
\hline $\mathrm{H}$ & -0.53840600 & 4.33155600 & -2.29000500 \\
\hline $\mathrm{H}$ & -0.89092200 & 4.81896000 & -0.62620500 \\
\hline $\mathrm{H}$ & -0.36365500 & 0.20348500 & -3.55139800 \\
\hline $\mathrm{C}$ & 1.15681600 & 2.85852300 & 1.06941800 \\
\hline $\mathrm{H}$ & 1.41388600 & 1.85722400 & 1.43354100 \\
\hline $\mathrm{H}$ & 2.06458300 & 3.47150300 & 1.09625600 \\
\hline $\mathrm{H}$ & 0.43096800 & 3.30004900 & 1.76023700 \\
\hline $\mathrm{C}$ & 4.10622500 & -0.46903100 & 1.37650500 \\
\hline $\mathrm{C}$ & 3.34835400 & -1.62085100 & 0.76116600 \\
\hline $\mathrm{C}$ & 3.85540100 & -2.06441100 & -0.59018500 \\
\hline $\mathrm{H}$ & 3.66045300 & -0.15550600 & 2.32398500 \\
\hline $\mathrm{H}$ & 3.19762800 & -2.45031400 & 1.45270000 \\
\hline $\mathrm{H}$ & 3.23075600 & -2.85467900 & -1.01406700 \\
\hline $\mathrm{H}$ & 3.86780900 & -1.22269200 & -1.29079300 \\
\hline $\mathrm{H}$ & 4.11260400 & 0.39176900 & 0.69904600 \\
\hline $\mathrm{H}$ & 5.14801500 & -0.75951200 & 1.56553600 \\
\hline $\mathrm{H}$ & 4.88106800 & -2.44610700 & -0.50193100 \\
\hline $\mathrm{Br}$ & 1.37147300 & -0.94405900 & 0.46655300 \\
\hline
\end{tabular}

$E[\mathrm{M} 06-2 \mathrm{X} / 6-311++\mathrm{G}(\mathrm{d}, \mathrm{p})]=-4285.10786193$ Hartrees $\Delta G[\mathrm{M} 06-2 \mathrm{X} / 6-31 \mathrm{G}(\mathrm{d})]=0.373203$ Hartrees Imaginary Frequency $=-179.24 \mathrm{~cm}^{-1}$

$(\mathrm{MeCN})$ 


\begin{tabular}{|c|c|c|c|}
\hline $\mathrm{Si}$ & -1.07194300 & 0.09731300 & 0.17072700 \\
\hline $\mathrm{Si}$ & 0.31140500 & 2.77234100 & 0.71701000 \\
\hline $\mathrm{Si}$ & -1.31806800 & -1.43624800 & 1.90771100 \\
\hline $\mathrm{Si}$ & -2.18159800 & -0.17583900 & -1.86410500 \\
\hline $\mathrm{O}$ & -0.97994400 & 1.70143700 & 0.65823100 \\
\hline $\mathrm{C}$ & 0.15840500 & -1.28107300 & 3.07296900 \\
\hline $\mathrm{H}$ & 0.14211800 & -2.07812600 & 3.82615200 \\
\hline $\mathrm{H}$ & 1.09325100 & -1.36176700 & 2.50650500 \\
\hline $\mathrm{H}$ & 0.15922400 & -0.32068800 & 3.59971200 \\
\hline $\mathrm{C}$ & -2.92338300 & -1.23891900 & 2.88151800 \\
\hline $\mathrm{H}$ & -3.79551800 & -1.36859400 & 2.23100600 \\
\hline $\mathrm{H}$ & -2.98505500 & -1.98625800 & 3.68217900 \\
\hline $\mathrm{H}$ & -2.99207700 & -0.24731500 & 3.34190200 \\
\hline $\mathrm{C}$ & -1.28502700 & -3.12495100 & 1.06239200 \\
\hline $\mathrm{H}$ & -0.40648600 & -3.21050500 & 0.41259600 \\
\hline $\mathrm{H}$ & -1.23838700 & -3.92947300 & 1.80629700 \\
\hline $\mathrm{H}$ & -2.18128200 & -3.28506100 & 0.45228800 \\
\hline $\mathrm{C}$ & -4.06145800 & -0.12319400 & -1.68377000 \\
\hline $\mathrm{H}$ & -4.55162800 & -0.24042900 & -2.65831700 \\
\hline $\mathrm{H}$ & -4.41314900 & -0.93013800 & -1.03042400 \\
\hline $\mathrm{H}$ & -4.39386800 & 0.82698900 & -1.25165500 \\
\hline $\mathrm{C}$ & -1.61753300 & 1.20810900 & -3.01663700 \\
\hline $\mathrm{H}$ & -0.53559600 & 1.17096600 & -3.18507700 \\
\hline $\mathrm{H}$ & -2.11233900 & 1.11662400 & -3.99145400 \\
\hline $\mathrm{C}$ & -1.66377800 & -1.84875300 & -2.56936400 \\
\hline $\mathrm{H}$ & -2.07423900 & -2.67738200 & -1.98162000 \\
\hline $\mathrm{H}$ & -2.02148200 & -1.95928300 & -3.60022800 \\
\hline $\mathrm{H}$ & -0.57274100 & -1.94402400 & -2.56870100 \\
\hline $\mathrm{C}$ & 1.02900700 & 2.97212800 & -1.00330600 \\
\hline $\mathrm{H}$ & 1.91043600 & 3.62465900 & -0.98196100 \\
\hline $\mathrm{H}$ & 1.34501600 & 1.99676500 & -1.39111400 \\
\hline $\mathrm{H}$ & 0.30649000 & 3.40708100 & -1.70273800 \\
\hline $\mathrm{C}$ & -0.36470500 & 4.39831500 & 1.34899100 \\
\hline $\mathrm{H}$ & 0.42699300 & 5.15600100 & 1.38139600 \\
\hline $\mathrm{H}$ & -1.16163600 & 4.77743700 & 0.69966500 \\
\hline $\mathrm{H}$ & -0.77238000 & 4.29716800 & 2.36084300 \\
\hline $\mathrm{H}$ & -1.86550400 & 2.19378500 & -2.60748600 \\
\hline $\mathrm{C}$ & 1.62245300 & 2.09796200 & 1.87511300 \\
\hline $\mathrm{H}$ & 1.97436400 & 1.12541300 & 1.51223900 \\
\hline $\mathrm{H}$ & 2.48544200 & 2.77327000 & 1.92210400 \\
\hline $\mathrm{H}$ & 1.23992300 & 1.97201100 & 2.89417600 \\
\hline $\mathrm{C}$ & 3.95633600 & -2.02992100 & 0.35267900 \\
\hline $\mathrm{C}$ & 3.45383700 & -1.42944400 & -0.93541000 \\
\hline $\mathrm{C}$ & 4.19956900 & -0.20645200 & -1.40457500 \\
\hline $\mathrm{H}$ & 3.33480600 & -2.86831900 & 0.67902000 \\
\hline $\mathrm{H}$ & 3.30118300 & -2.16792600 & -1.72262600 \\
\hline $\mathrm{H}$ & 3.76059200 & 0.21214400 & -2.31443600 \\
\hline $\mathrm{H}$ & 4.20331900 & 0.56938400 & -0.63089500 \\
\hline $\mathrm{H}$ & 3.97678800 & -1.27956200 & 1.15066200 \\
\hline $\mathrm{H}$ & 4.98108800 & -2.40017600 & 0.21362700 \\
\hline $\mathrm{H}$ & 5.24370000 & -0.46985600 & -1.62154900 \\
\hline $\mathrm{Br}$ & 1.44710600 & -0.80214600 & -0.56058100 \\
\hline
\end{tabular}

$E[\mathrm{M} 06-2 \mathrm{X} / 6-311++\mathrm{G}(\mathrm{d}, \mathrm{p})]=-4285.11774618$ Hartrees $\Delta G[\mathrm{M} 06-2 \mathrm{X} / 6-31 \mathrm{G}(\mathrm{d})]=0.372027$ Hartrees

Imaginary Frequency $=-205.50 \mathrm{~cm}^{-1}$ 


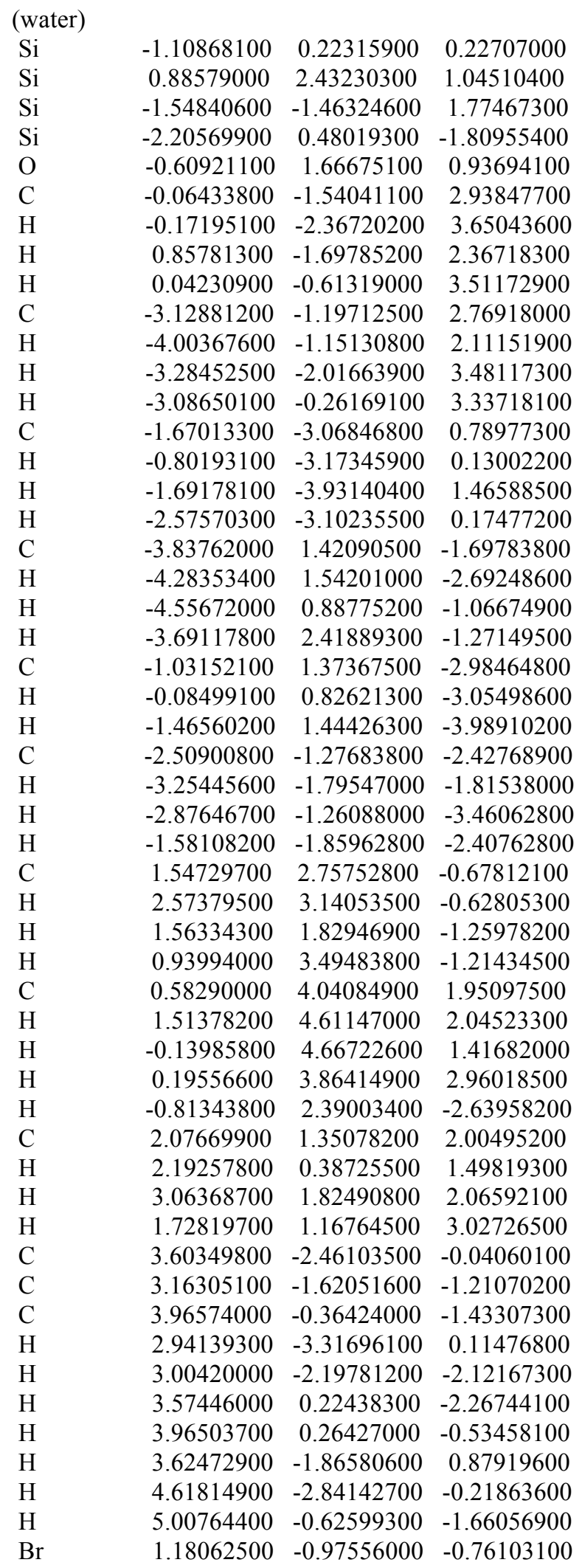

$E[\mathrm{M} 06-2 \mathrm{X} / 6-311++\mathrm{G}(\mathrm{d}, \mathrm{p})]=-4285.10070895$ Hartrees 
$\Delta G[\mathrm{M} 06-2 \mathrm{X} / 6-31 \mathrm{G}(\mathrm{d})]=0.374232$ Hartrees Imaginary Frequency $=-205.73 \mathrm{~cm}^{-1}$

TS-E (C-F Abstraction by Silyl Radical)

\begin{tabular}{|c|c|c|c|}
\hline $\mathrm{C}$ & & & \\
\hline $\mathrm{C}$ & -219856200 & -047818900 & 7300 \\
\hline $\mathrm{C}$ & -2.05504100 & -1.86967300 & 2.84497500 \\
\hline $\mathrm{H}$ & -2.07813200 & 1.61799800 & 2.79184400 \\
\hline $\mathrm{H}$ & -2.99371100 & -0.34709400 & 1.58008700 \\
\hline $\mathrm{H}$ & -2.10309500 & -2.61332000 & 2.04523100 \\
\hline $\mathrm{H}$ & -1.10009700 & -1.97978700 & 3.36797000 \\
\hline $\mathrm{H}$ & -1.10575700 & 0.55697600 & 3.83296900 \\
\hline $\mathrm{Si}$ & 0.58205600 & 0.01452200 & -0.11968400 \\
\hline $\mathrm{H}$ & -2.86661700 & 0.61861800 & 4.02810000 \\
\hline $\mathrm{H}$ & -2.85877100 & -2.09034300 & 3.56194200 \\
\hline $\mathrm{Si}$ & 1.59260300 & 2.08367500 & 0.21123500 \\
\hline $\mathrm{Si}$ & 1.87532000 & -1.90348900 & -0.32930300 \\
\hline $\mathrm{C}$ & 0.65607000 & -3.33922300 & -0.51518800 \\
\hline $\mathrm{H}$ & 0.00569600 & -3.18323100 & -1.38262400 \\
\hline $\mathrm{H}$ & 1.17778000 & -4.29349600 & -0.64787300 \\
\hline $\mathrm{H}$ & 0.01734400 & -3.41949400 & 0.37125100 \\
\hline $\mathrm{C}$ & 3.03823200 & -1.88758700 & -1.82283900 \\
\hline $\mathrm{H}$ & 3.78546800 & -1.09278300 & -1.72656000 \\
\hline $\mathrm{H}$ & 3.56872800 & -2.84247000 & -1.91944000 \\
\hline $\mathrm{H}$ & 2.48113800 & -1.71239200 & -2.74850600 \\
\hline $\mathrm{C}$ & 2.90227100 & -2.14998000 & 1.24071500 \\
\hline $\mathrm{H}$ & 2.26570200 & -2.15988300 & 2.13167900 \\
\hline $\mathrm{H}$ & 3.44115800 & -3.10340200 & 1.20084500 \\
\hline $\mathrm{H}$ & 3.64353400 & -1.35351700 & 1.36495700 \\
\hline $\mathrm{C}$ & 3.24562300 & 1.80590400 & 1.09218500 \\
\hline $\mathrm{H}$ & 3.93669200 & 1.23376200 & 0.46331100 \\
\hline $\mathrm{H}$ & 3.72312800 & 2.76269700 & 1.33126100 \\
\hline $\mathrm{H}$ & 3.10921100 & 1.25634000 & 2.02979900 \\
\hline $\mathrm{C}$ & 0.49560200 & 3.16464100 & 1.31350000 \\
\hline $\mathrm{H}$ & 0.94961200 & 4.14850300 & 1.47831800 \\
\hline $\mathrm{H}$ & -0.48977300 & 3.31966800 & 0.86057200 \\
\hline $\mathrm{H}$ & 0.34516000 & 2.69048300 & 2.28922000 \\
\hline $\mathrm{C}$ & 1.88838000 & 2.98768800 & -1.42360300 \\
\hline $\mathrm{H}$ & 2.31353500 & 3.98384700 & -1.25440100 \\
\hline $\mathrm{H}$ & 2.57830400 & 2.42395000 & -2.05964100 \\
\hline $\mathrm{H}$ & 0.95052000 & 3.10725500 & -1.97590200 \\
\hline $\mathrm{O}$ & -0.46746400 & 0.08453900 & -1.42817300 \\
\hline $\mathrm{Si}$ & -2.11557600 & 0.17983700 & -1.59903900 \\
\hline $\mathrm{C}$ & -2.88350600 & -1.44661400 & -1.05012000 \\
\hline $\mathrm{H}$ & -3.96123300 & -1.36058800 & -0.87257600 \\
\hline $\mathrm{H}$ & -2.72974500 & -2.21845500 & -1.81173100 \\
\hline $\mathrm{H}$ & -2.40645300 & -1.79428400 & -0.12780900 \\
\hline $\mathrm{C}$ & -2.47470000 & 0.47281500 & -3.41369700 \\
\hline $\mathrm{H}$ & -3.55243200 & 0.53880700 & -3.59890400 \\
\hline $\mathrm{H}$ & -2.01551200 & 1.40496600 & -3.75801700 \\
\hline $\mathrm{H}$ & -2.07705800 & -0.34268900 & -4.02603300 \\
\hline $\mathrm{C}$ & -2.75431000 & 1.62998600 & -0.58547600 \\
\hline $\mathrm{H}$ & -2.37098300 & 1.58429600 & 0.43948500 \\
\hline
\end{tabular}




$\begin{array}{lrrr}\mathrm{H} & -2.41324600 & 2.57505900 & -1.02371800 \\ \mathrm{H} & -3.84867000 & 1.65720300 & -0.54343900 \\ \mathrm{~F} & -0.83464300 & -0.30041400 & 1.30572300\end{array}$

$E[\mathrm{M} 06-2 \mathrm{X} / 6-311++\mathrm{G}(\mathrm{d}, \mathrm{p})]=-1810.74281466$ Hartrees $\Delta G[\mathrm{M} 06-2 \mathrm{X} / 6-31 \mathrm{G}(\mathrm{d})]=0.370653$ Hartrees Imaginary Frequency $=-955.37 \mathrm{~cm}^{-1}$

$\begin{array}{lrrr}(\mathrm{MeCN}) & & & \\ \mathrm{C} & -2.14737600 & 1.44422000 & 2.96996000 \\ \mathrm{C} & -2.24610700 & 0.09852900 & 2.32883500 \\ \mathrm{C} & -2.07378800 & -1.09509200 & 3.21079300 \\ \mathrm{H} & -2.19101800 & 2.24932100 & 2.23126500 \\ \mathrm{H} & -3.02036000 & 0.00407100 & 1.56973600 \\ \mathrm{H} & -2.06514800 & -2.02537800 & 2.63608200 \\ \mathrm{H} & -1.14485700 & -1.02145000 & 3.78534700 \\ \mathrm{H} & -1.21980000 & 1.53407400 & 3.54442100 \\ \mathrm{Si} & 0.58201900 & -0.00312600 & -0.09858900 \\ \mathrm{H} & -2.98631500 & 1.58179100 & 3.66740700 \\ \mathrm{H} & -2.90635800 & -1.14785600 & 3.92696300 \\ \mathrm{Si} & 1.64214400 & 2.06452000 & -0.17866700 \\ \mathrm{Si} & 1.84904600 & -1.94805900 & 0.05613000 \\ \mathrm{C} & 0.68570100 & -3.41417500 & -0.21671200 \\ \mathrm{H} & 0.24626300 & -3.39041200 & -1.22044200 \\ \mathrm{H} & 1.22838900 & -4.36190000 & -0.11305200 \\ \mathrm{H} & -0.13281700 & -3.41500900 & 0.51235100 \\ \mathrm{C} & 3.27785500 & -2.06989300 & -1.18097700 \\ \mathrm{H} & 4.00143200 & -1.26014900 & -1.03066200 \\ \mathrm{H} & 3.81094200 & -3.02283300 & -1.06612400 \\ \mathrm{H} & 2.91781400 & -2.00831200 & -2.21406600 \\ \mathrm{C} & 2.57445500 & -2.04396100 & 1.79951500 \\ \mathrm{H} & 1.78389600 & -2.04691900 & 2.55869000 \\ \mathrm{H} & 3.16568800 & -2.95956900 & 1.92440800 \\ \mathrm{H} & 3.23309600 & -1.19224700 & 2.00634700 \\ \mathrm{C} & 3.08883600 & 2.07865000 & 1.04032200 \\ \mathrm{H} & 3.88522300 & 1.39345800 & 0.72686300 \\ \mathrm{H} & 3.52354900 & 3.08384600 & 1.10370400 \\ \mathrm{H} & 2.77182700 & 1.79052100 & 2.04896800 \\ \mathrm{C} & 0.40422100 & 3.40582900 & 0.31854000 \\ \mathrm{H} & 0.86240700 & 4.40051900 & 0.24898500 \\ \mathrm{H} & -0.47650400 & 3.40058400 & -0.33434100 \\ \mathrm{H} & 0.05929800 & 3.26618600 & 1.34947600 \\ \mathrm{C} & 2.28910000 & 2.48006800 & -1.90767000 \\ \mathrm{H} & 2.72877100 & 3.48538000 & -1.93144800 \\ \mathrm{H} & 3.05699600 & 1.76622600 & -2.22640600 \\ \mathrm{H} & 1.48063100 & 2.45120700 & -2.64716100 \\ \mathrm{O} & -0.45346900 & -0.12782100 & -1.42127500 \\ \mathrm{Si} & -2.10825400 & -0.19539500 & -1.60162700 \\ \mathrm{C} & -2.77493200 & -1.71280900 & -0.72151700 \\ \mathrm{H} & -3.86922400 & -1.68751800 & -0.65311800 \\ \mathrm{H} & -2.49857500 & -2.62448400 & -1.26418800 \\ \mathrm{H} & -2.37398800 & -1.79286700 & 0.29439100 \\ \mathrm{C} & -2.45511100 & -0.34217400 & -3.43639200 \\ \mathrm{H} & -3.53477700 & -0.34776100 & -3.62816200 \\ \mathrm{H} & -2.02308400 & 0.49895600 & -3.99031700 \\ & -2.03946200 & -1.26817500 & -3.84926100\end{array}$




$\begin{array}{lrrr}\mathrm{C} & -2.87064400 & 1.39201000 & -0.94860400 \\ \mathrm{H} & -2.45045700 & 1.66164300 & 0.02661800 \\ \mathrm{H} & -2.67459300 & 2.22281700 & -1.63692400 \\ \mathrm{H} & -3.95781800 & 1.30323200 & -0.83664200 \\ \mathrm{~F} & -0.84288100 & 0.03591300 & 1.31471800\end{array}$

$E[\mathrm{M} 06-2 \mathrm{X} / 6-311++\mathrm{G}(\mathrm{d}, \mathrm{p})]=-1810.75389081$ Hartrees $\Delta G[\mathrm{M} 06-2 \mathrm{X} / 6-31 \mathrm{G}(\mathrm{d})]=0.371786$ Hartrees Imaginary Frequency $=-1027.69 \mathrm{~cm}^{-1}$

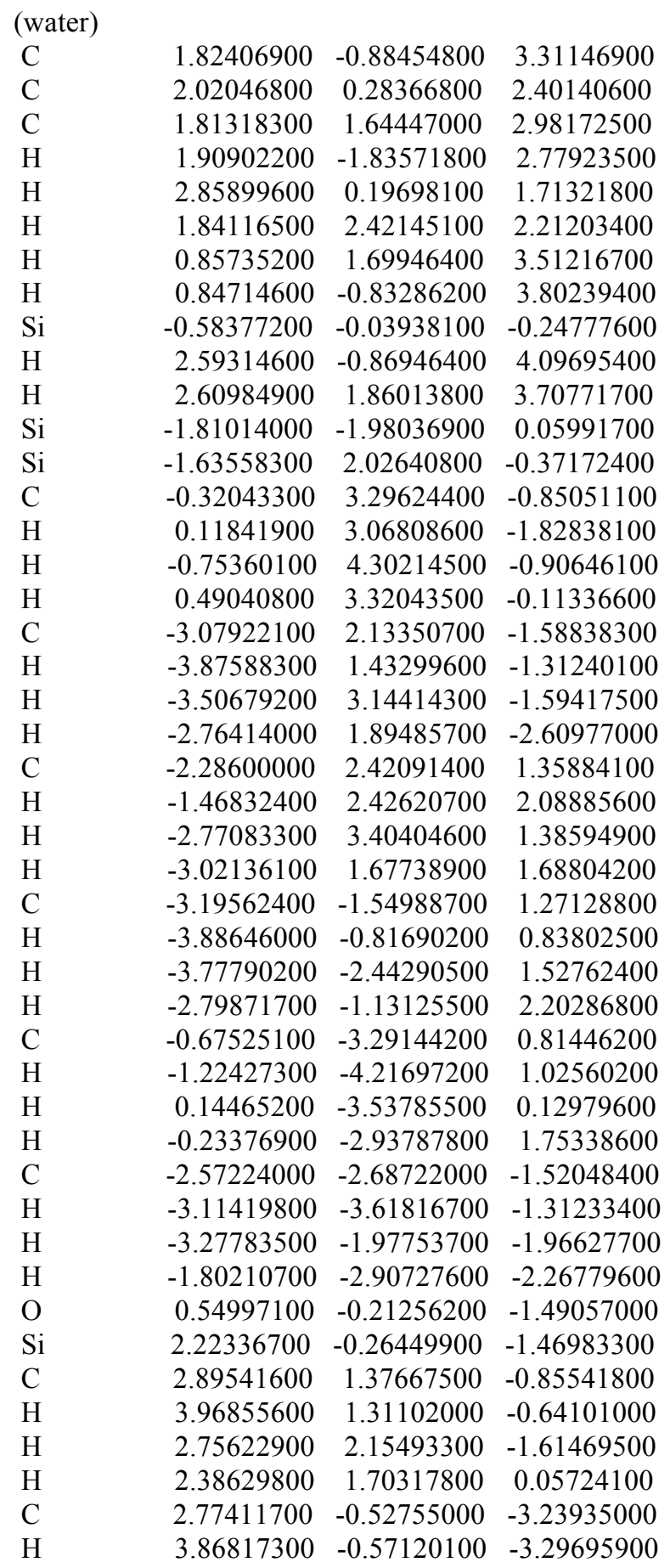




$\begin{array}{lrrr}\mathrm{H} & 2.38332300 & -1.46583200 & -3.64772300 \\ \mathrm{H} & 2.44116600 & 0.28974700 & -3.88830700 \\ \mathrm{C} & 2.78878300 & -1.71655300 & -0.42255100 \\ \mathrm{H} & 2.24517000 & -1.76479900 & 0.52695400 \\ \mathrm{H} & 2.61550000 & -2.65862100 & -0.95600200 \\ \mathrm{H} & 3.86008200 & -1.65646300 & -0.19818700 \\ \mathrm{~F} & 0.71599600 & 0.13945500 & 1.27413400\end{array}$

$E[\mathrm{M} 06-2 \mathrm{X} / 6-311++\mathrm{G}(\mathrm{d}, \mathrm{p})]=-1810.73746223$ Hartrees $\Delta G[\mathrm{M} 06-2 \mathrm{X} / 6-31 \mathrm{G}(\mathrm{d})]=0.372754$ Hartrees Imaginary Frequency $=-1037.85 \mathrm{~cm}^{-1}$

TS-F (N-F Abstraction by Carbon Radical)

$\begin{array}{lccc}\text { (gas) } & & & \\ \mathrm{N} & -0.38326100 & 0.46078500 & 0.83967100 \\ \mathrm{~S} & -1.12476400 & 0.78325200 & -0.70372800 \\ \mathrm{~S} & 0.24149500 & -1.12129400 & 1.15701800 \\ \mathrm{O} & -0.55750600 & -0.05751000 & -1.74593400 \\ \mathrm{O} & -1.07331900 & 2.22722300 & -0.81748600 \\ \mathrm{O} & 0.56900000 & -1.10508100 & 2.56556100 \\ \mathrm{O} & -0.75143100 & -2.02769800 & 0.60613800 \\ \mathrm{C} & 3.36947500 & 2.68037400 & 1.04358500 \\ \mathrm{H} & 3.87940800 & 1.71200900 & 1.05838500 \\ \mathrm{H} & 2.95920900 & 2.88232100 & 2.03676200 \\ \mathrm{H} & 4.13409900 & 3.44719600 & 0.84195300 \\ \mathrm{C} & 2.31056400 & 2.70520300 & -0.00064700 \\ \mathrm{H} & 1.57841000 & 3.50479600 & 0.04103100 \\ \mathrm{C} & 2.51562500 & 2.03568300 & -1.31260400 \\ \mathrm{H} & 2.98553800 & 1.05419600 & -1.18352600 \\ \mathrm{H} & 1.56782900 & 1.90733500 & -1.84246700 \\ \mathrm{H} & 3.17996300 & 2.63460500 & -1.95504000 \\ \mathrm{~F} & 0.90158700 & 1.35883300 & 0.74117200 \\ \mathrm{C} & 1.76134100 & -1.27541500 & 0.25162100 \\ \mathrm{C} & 1.74446800 & -1.77531900 & -1.04659100 \\ \mathrm{C} & 2.94514300 & -0.94890500 & 0.90890000 \\ \mathrm{C} & 2.95838800 & -1.93171700 & -1.71012500 \\ \mathrm{H} & 0.80219100 & -2.02708300 & -1.51796900 \\ \mathrm{C} & 4.14958800 & -1.11761800 & 0.23421900 \\ \mathrm{H} & 2.90893400 & -0.58636200 & 1.93091100 \\ \mathrm{C} & 4.15363700 & -1.60402600 & -1.07310900 \\ \mathrm{H} & 2.96904000 & -2.31753200 & -2.72398000 \\ \mathrm{H} & 5.08421900 & -0.87499500 & 0.72995500 \\ \mathrm{H} & 5.09601500 & -1.73468700 & -1.59599900 \\ \mathrm{C} & -2.78359500 & 0.27470700 & -0.36284900 \\ \mathrm{C} & -3.61790700 & 1.16526100 & 0.30830700 \\ \mathrm{C} & -3.21327900 & -0.97628000 & -0.79363500 \\ \mathrm{C} & -4.92934200 & 0.77969600 & 0.55935700 \\ \mathrm{H} & -3.24065500 & 2.13581300 & 0.61316100 \\ \mathrm{C} & -4.52976500 & -1.34379000 & -0.53645100 \\ \mathrm{H} & -2.52309400 & -1.63834300 & -1.30370800 \\ \mathrm{H} & -5.38080300 & -0.47047600 & 0.13785600 \\ \mathrm{H} & -4.58960100 & 1.45510300 & 1.08031500 \\ \mathrm{H} & & -2.31442100 & -0.86056100 \\ \mathrm{H} & -0.76601000 & 0.33666600\end{array}$


$E[\mathrm{M} 06-2 \mathrm{X} / 6-311++\mathrm{G}(\mathrm{d}, \mathrm{p})]=-1833.25065218$ Hartrees $\Delta G[\mathrm{M} 06-2 \mathrm{X} / 6-31 \mathrm{G}(\mathrm{d})]=0.249398$ Hartrees Imaginary Frequency $=-876.33 \mathrm{~cm}^{-1}$

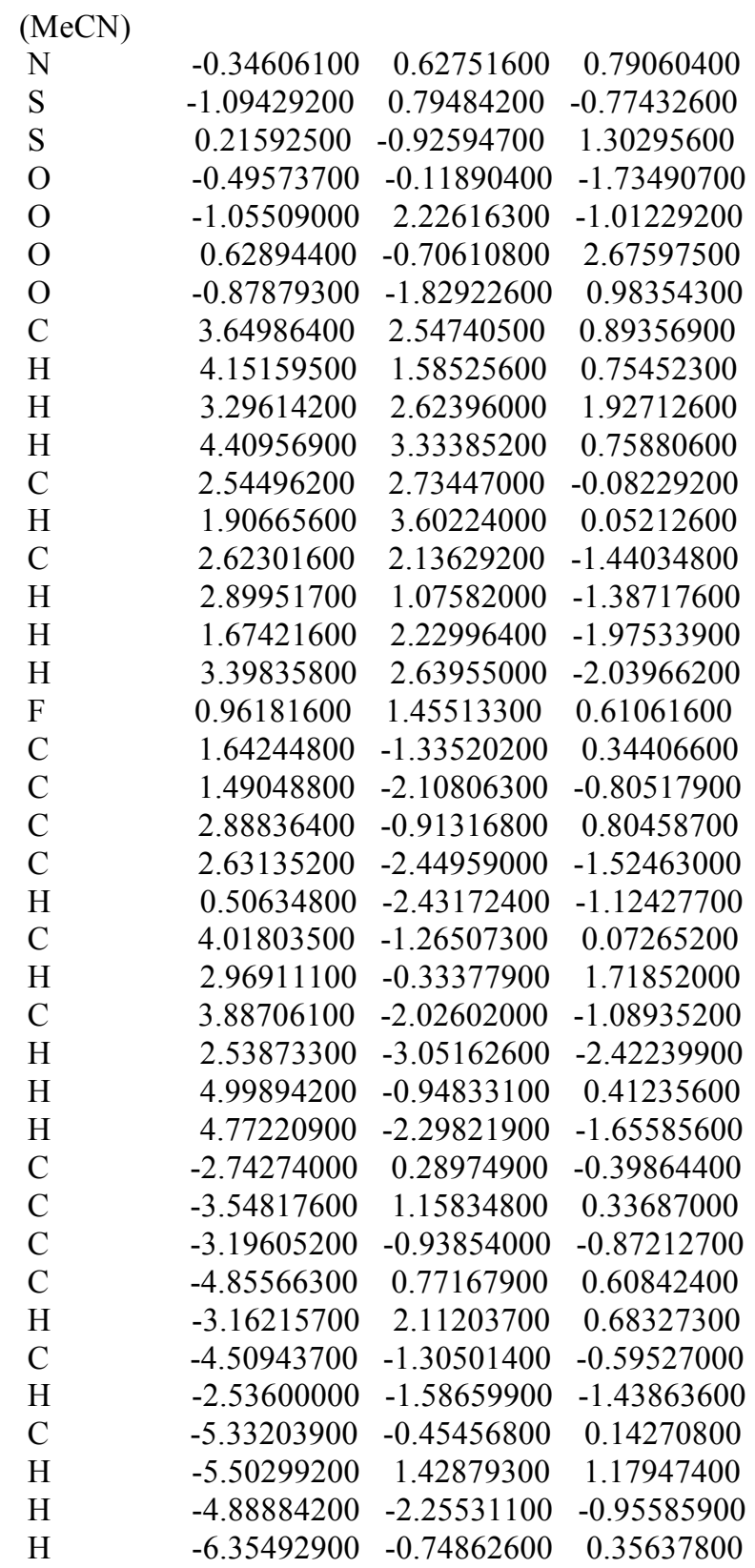

$E[\mathrm{M} 06-2 \mathrm{X} / 6-311++\mathrm{G}(\mathrm{d}, \mathrm{p})]=-1833.28083764$ Hartrees $\Delta G[\mathrm{M} 06-2 \mathrm{X} / 6-31 \mathrm{G}(\mathrm{d})]=0.247422$ Hartrees Imaginary Frequency $=-1035.40 \mathrm{~cm}^{-1}$

$\begin{array}{lccc}\text { (water) } & & & \\ \mathrm{N} & -0.34303800 & 0.66229900 & 0.82930000 \\ \mathrm{~S} & -1.08729300 & 0.86748100 & -0.73153800 \\ \mathrm{~S} & 0.19644400 & -0.90769200 & 1.32017000 \\ \mathrm{O} & -0.44981100 & 0.01221200 & -1.72319700\end{array}$




$\begin{array}{lrrr}\mathrm{O} & -1.06506100 & 2.31031200 & -0.91429500 \\ \mathrm{O} & 0.61516700 & -0.70256100 & 2.69619200 \\ \mathrm{O} & -0.92129000 & -1.78846200 & 1.00975300 \\ \mathrm{C} & 3.72572100 & 2.47136800 & 0.82415700 \\ \mathrm{H} & 4.20622200 & 1.49769200 & 0.69232000 \\ \mathrm{H} & 3.39185100 & 2.57090500 & 1.86217200 \\ \mathrm{H} & 4.49790200 & 3.24037800 & 0.66469200 \\ \mathrm{C} & 2.60725000 & 2.66566200 & -0.13426700 \\ \mathrm{H} & 1.99569000 & 3.55384500 & -0.01070300 \\ \mathrm{C} & 2.63419600 & 2.02008800 & -1.47258000 \\ \mathrm{H} & 2.85392000 & 0.94797800 & -1.39006500 \\ \mathrm{H} & 1.68765300 & 2.14845200 & -2.00404300 \\ \mathrm{H} & 3.42839800 & 2.46099700 & -2.09538100 \\ \mathrm{~F} & 0.97402500 & 1.45255400 & 0.64057800 \\ \mathrm{C} & 1.60490700 & -1.33813200 & 0.35301900 \\ \mathrm{C} & 1.42768900 & -2.10003600 & -0.80044400 \\ \mathrm{C} & 2.86068900 & -0.93916800 & 0.80769000 \\ \mathrm{C} & 2.55682300 & -2.45658900 & -1.52986300 \\ \mathrm{H} & 0.43683900 & -2.40955400 & -1.11378100 \\ \mathrm{C} & 3.97711000 & -1.30867600 & 0.06529700 \\ \mathrm{H} & 2.96092200 & -0.36282400 & 1.72145200 \\ \mathrm{C} & 3.82305000 & -2.05972500 & -1.09999100 \\ \mathrm{H} & 2.44689500 & -3.05097700 & -2.43025500 \\ \mathrm{H} & 4.96557400 & -1.01106200 & 0.39918400 \\ \mathrm{H} & 4.69865400 & -2.34535400 & -1.67399800 \\ \mathrm{C} & -2.72475900 & 0.31478100 & -0.40185000 \\ \mathrm{C} & -3.54016700 & 1.10796700 & 0.40511900 \\ \mathrm{C} & -3.15672000 & -0.87868100 & -0.97500900 \\ \mathrm{C} & -4.83969200 & 0.67760700 & 0.64482700 \\ \mathrm{H} & -3.16982700 & 2.03498900 & 0.83129300 \\ \mathrm{C} & -4.46282700 & -1.28729600 & -0.72717000 \\ \mathrm{H} & -2.48895600 & -1.46791000 & -1.59440000 \\ \mathrm{C} & -5.29638700 & -0.51365700 & 0.07955200 \\ \mathrm{H} & -5.49583900 & 1.27370500 & 1.26948500 \\ \mathrm{H} & -4.82739000 & -2.21038600 & -1.16420400 \\ & -6.31322000 & -0.84168000 & 0.26927700\end{array}$

$E[\mathrm{M} 06-2 \mathrm{X} / 6-311++\mathrm{G}(\mathrm{d}, \mathrm{p})]=-1833.27445413$ Hartrees $\Delta G[\mathrm{M} 06-2 \mathrm{X} / 6-31 \mathrm{G}(\mathrm{d})]=0.246557$ Hartrees Imaginary Frequency $=-1055.79 \mathrm{~cm}^{-1}$ 


\section{References}

1. Perrin, D. D.; Armarego, W. L. F. Purification of Laboratory Chemicals (Pergamon Press: Oxford, 1988) ed 3.

2. Still, W. C.; Kahn, M.; Mitra, A. J. Org. Chem. 1978, 43, 2923

3. (TMS) $)_{3} \mathrm{SiOH}$ was prepared using the protocol outlines in: Le, C.; Chen, T. Q.; Liang, T.; Zhang, P.;

MacMillan, D. W. C. Science, 2018, 360, 1010.

4. X. Yu, T. Yang, S. Wang, H. Xu, and H. Gong, Org. Lett. 2011, 8, 2138.

5. Smith, R. T.; Zhang, X.; Ricón, J. A.; Agejas, J.; Mateos, C.; Barberis, M.; García-Cerrada, S.; de

Frutos, O.; MacMillan, D. W. C. J. Am. Chem. Soc., 2018, 140, 17433.

6. Perry, I. B.; Brewer, T. F.; Sarver, P. J.; Schultz, D. M.; DiRocco, D. A.; MacMillan, D. W. C. Nature 2018, 560, 70 .

7. Chen. H.; Liu, Z.; Lv, Y.; Tan, X.; Shen H.; Yu, H.-Z.; Li, C. Angew. Chem. Int. Ed., 2017, 56, 15411.

8. Takeda, T.; Sasaki, R.; Yamauchi, S.; Fujiwara, T. Tetrahedron, 1997, 53, 557.

9. Dudnik, A.S.; Fu, G.C. J. Am. Chem. Soc., 2012, 134, 10693

10. Kim, K.-Y.; Kim, B.C.; Lee, H.B.; Shin, H. J. Org. Chem., 2008, 73, 8106.

11. Schneider, H.-J.; Gschwendtner, W.; Heiske, D.; Hoppen, V.; Thomas, H. Tetrahedron, 1977, 11, 1769.

12. Mohanta, P.K.; Davis, T.A.; Gooch, J.R.; Flowers, R.A. J. Am. Chem. Soc., 2005, 127, 11896.

13. Patrick, T.B.; Zhang, L.; Li.; Q. J. Fluorine Chem., 2000, 102, 11.

14. Shishimi, T.; Hara, S. J. Fluorine. Chem., 2014, 168, 55.

15. Barker, T.J.; Boger, D.L. J. Am. Chem. Soc., 2012, 134, 13588.

16. Sandford, C.; Rasappan, R.; Aggarwal, V.K. J. Am. Chem. Soc., 2015, 137, 10100.

17. Chen. H.; Liu, Z.; Lv, Y.; Tan, X.; Shen H.; Yu, H.-Z.; Li, C. Angew. Chem. Int. Ed., 2017, 56, 15411.

18. Hara, S.; Aoyama, M.; Synthesis, 2008, 16, 2510.

19. Knoll, W.; Mieusset, J.-L.; Arion, V.B.; Brecker, L.; Brinker, U.H. Org. Lett., 2010, 12, 2366.

20. Said, M. S.; Khandare, L.; Shinde, S. S. Tetrahedron Lett., 2017, 58, 59.

21. Yadav, A.K.; Srivastava, V.P.; Tadav, L.D.S. Chem. Comm., 2013, 49, 2154.

22. Launay, G.G.; Slawin, A.M.Z.; O’Hagan, D. Bilstein J. Org. Chem. 2010, 6, 41.

23. Cavalcanti, S.C.H.; Xiang, Y.; Newton, M.G.; Schinazi, R.F.; Cheng, Y.-C.; Chu, C.K. Nucleosides and Nucleotides, 1999, 18, 2233.

24. Nacsa, E. D.; MacMillan, D.W.C. Spin-Center Shift-Enabled Direct Enantioslective $\alpha$-Benzylation of Aldehydes with Alcohols. J. Am. Chem. Soc. 2018, 140, 3322.

25.Nodwell, M. B.; Yang, H.; Čolović, M.; Yuan, Z.; Merkens, H.; Martin, R. R.; Bérnard, F.; Schaffer, P.; Britton, P. J. Am. Chem. Soc., 2017, 139, 3595.

26. Frisch, M. J.; Trucks, G. W.; Schlegel, H. B.; Scuseria, G. E.; Robb, M. A.; Cheeseman, J. R.; Scalmani, G.;

Barone, V.; Mennucci, B.; Petersson, G. A.; Nakatsuji, H.; Caricato, M.; Li, X.; Hratchian, H. P.; Izmaylov, A. F.; Bloino, J.; Zheng, G.; Sonnenberg, J. L.; Hada, M.; Ehara, M.; Toyota, K.; Fukuda, R.; Hasegawa, J.; Ishida, M.;

Nakajima, T.; Honda, Y.; Kitao, O.; Nakai, H.; Vreven, T.; Montgomery, J. A.; Peralta, J. E.; Ogliaro, F.; Bearpark, M.; Heyd, J. J.; Brothers, E.; Kudin, K. N.; Staroverov, V. N.; Kobayashi, R.; Normand, J.; Raghavachari, K.;

Rendell, A.; Burant, J. C.; Iyengar, S. S.; Tomasi, J.; Cossi, M.; Rega, N.; Millam, J. M.; Klene, M.; Knox, J. E.;

Cross, J. B.; Bakken, V.; Adamo, C.; Jaramillo, J.; Gomperts, R.; Stratmann, R. E.; Yazyev, O.; Austin, A. J.;

Cammi, R.; Pomelli, C.; Ochterski, J. W.; Martin, R. L.; Morokuma, K.; Zakrzewski, V. G.; Voth, G. A.; Salvador, P.; Dannenberg, J. J.; Dapprich, S.; Daniels, A. D.; Farkas; Foresman, J. B.; Ortiz, J. V.; Cioslowski, J.; Fox, D. J. Gaussian 09; Gaussian Inc.: Wallingford, CT, 2009. 
27. Zhao, Y.; Truhlar, D. G. Theor. Chem. Acc. 2008, 120, 215.

28. Marenich, A. V.; Cramer, C. J.; Truhlar, D. G. J. Phys. Chem. B 2009, 113, 6378.

29. Legault, C. Y. CYLview, 1.0b; Université de Sherbrooke, 2009 (http://www.cylview.org).

\section{Spectral Data}


<smiles>CCC(C)(Br)CCc1ccccc1</smiles>
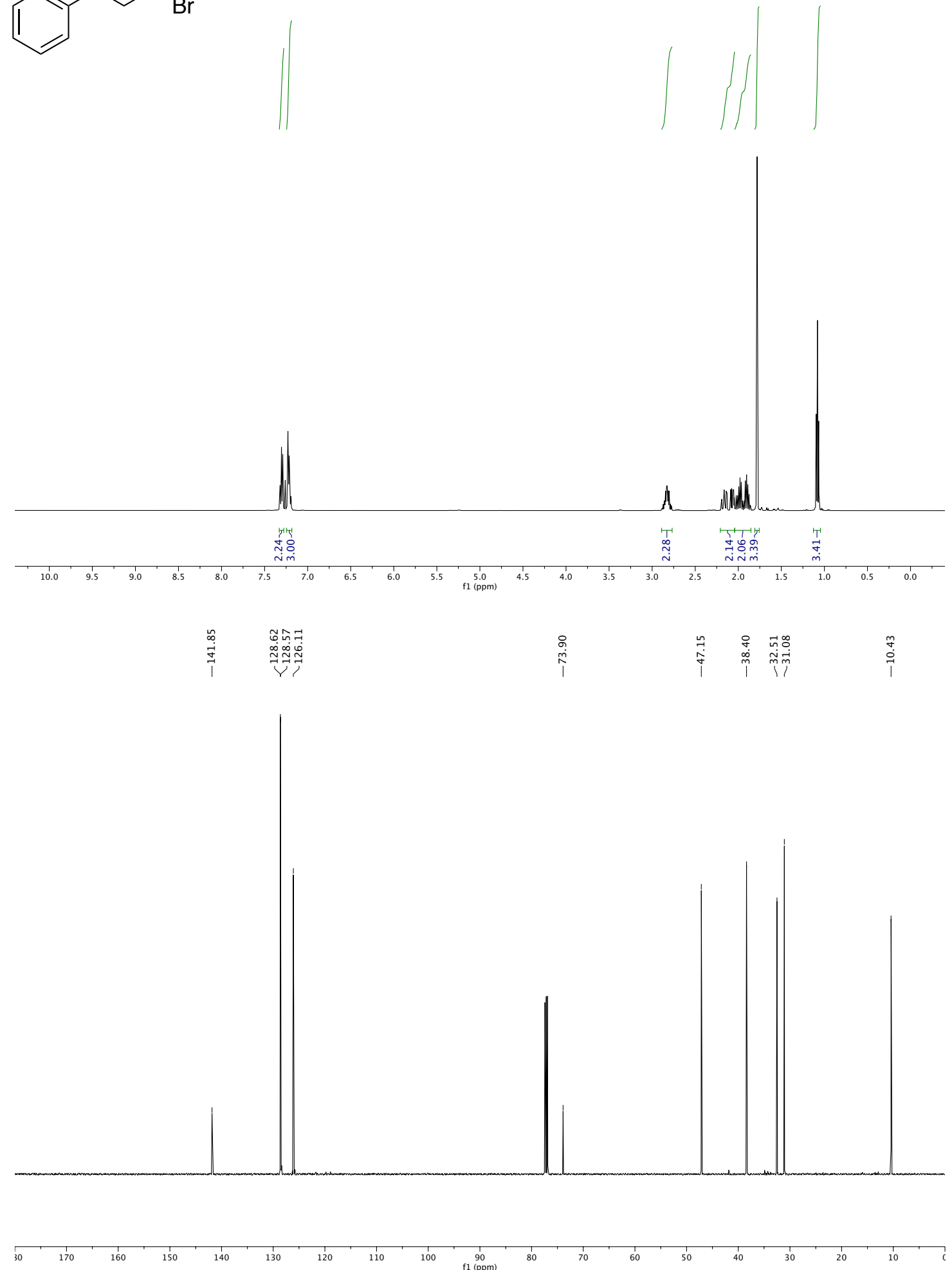

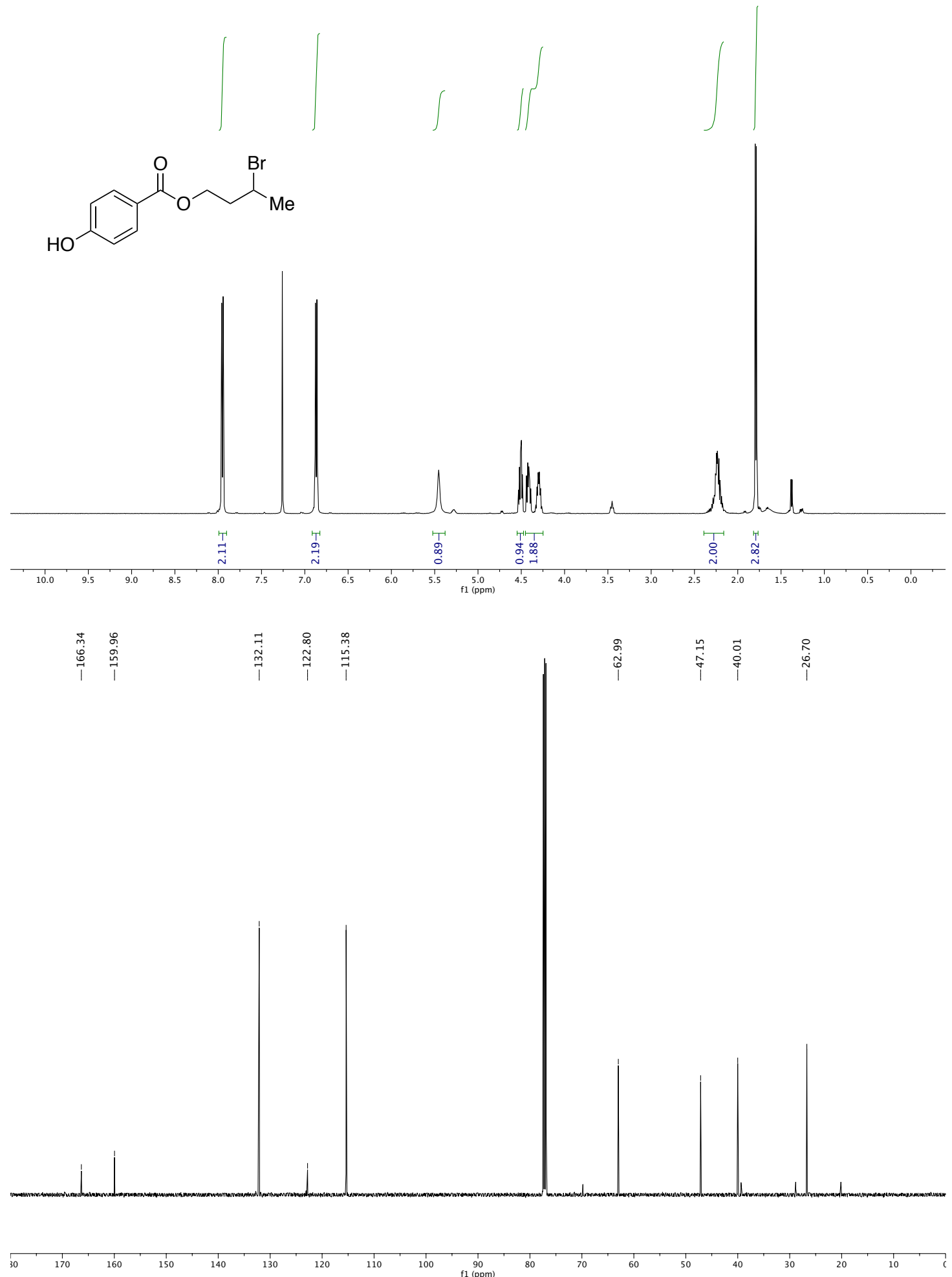


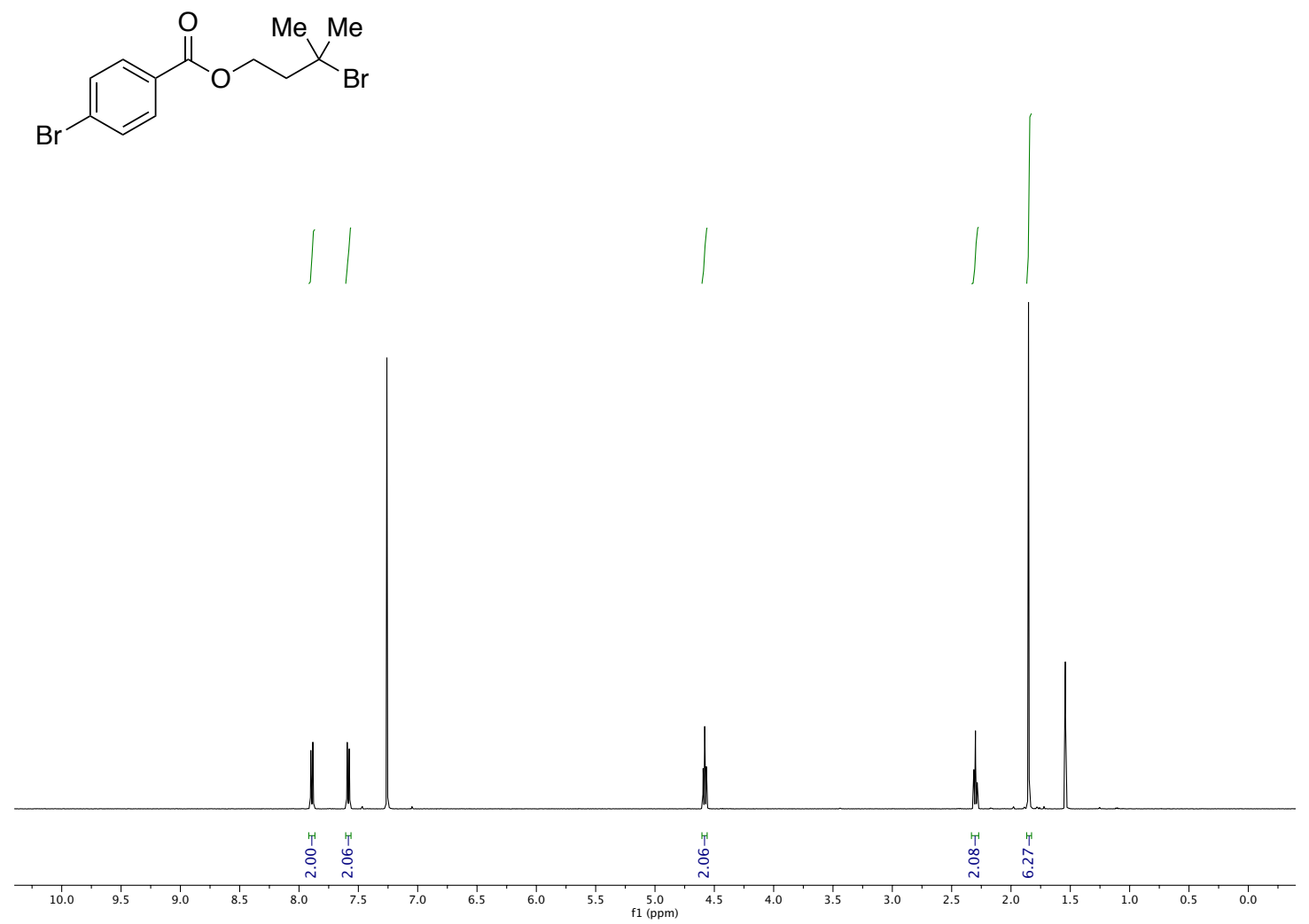

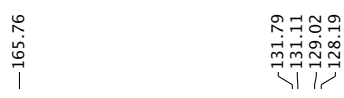

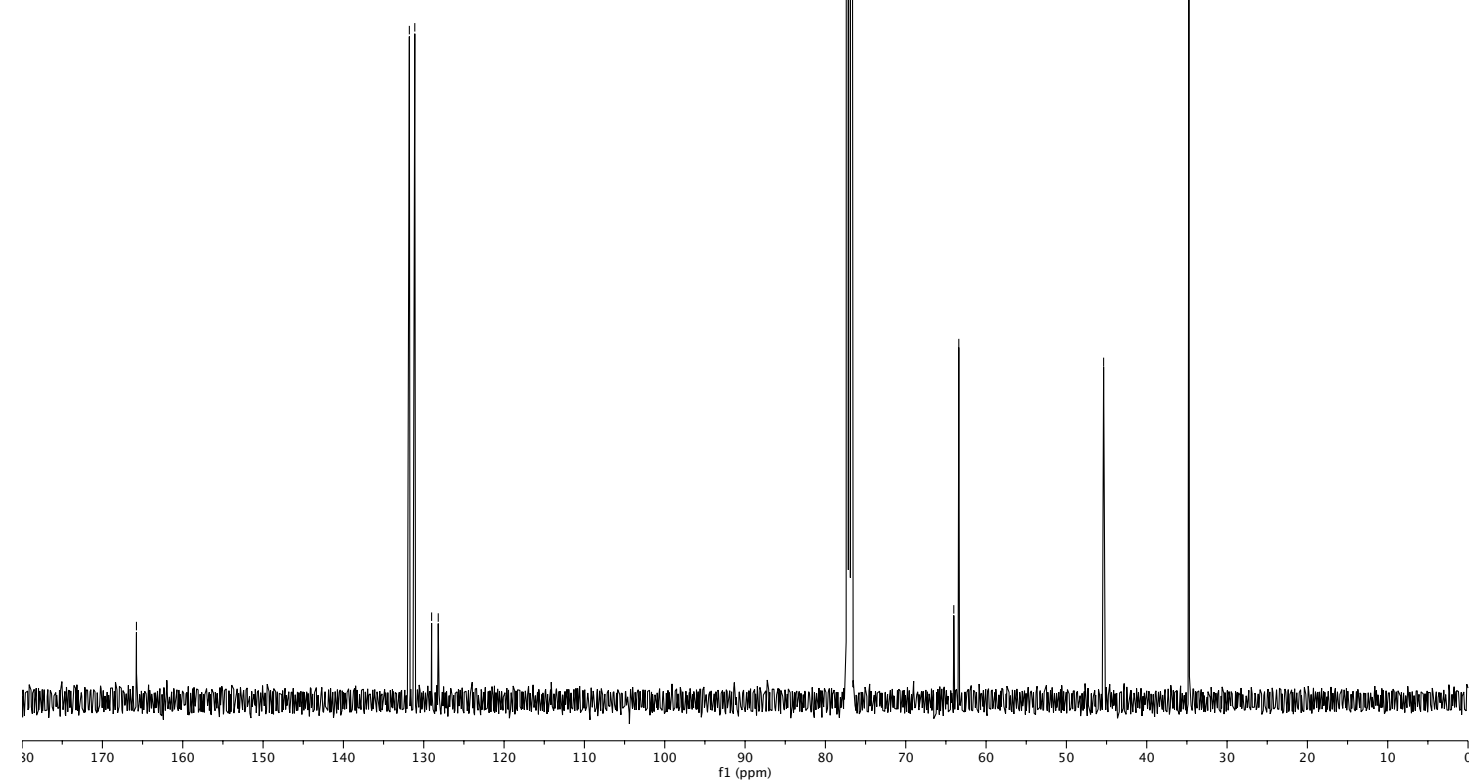



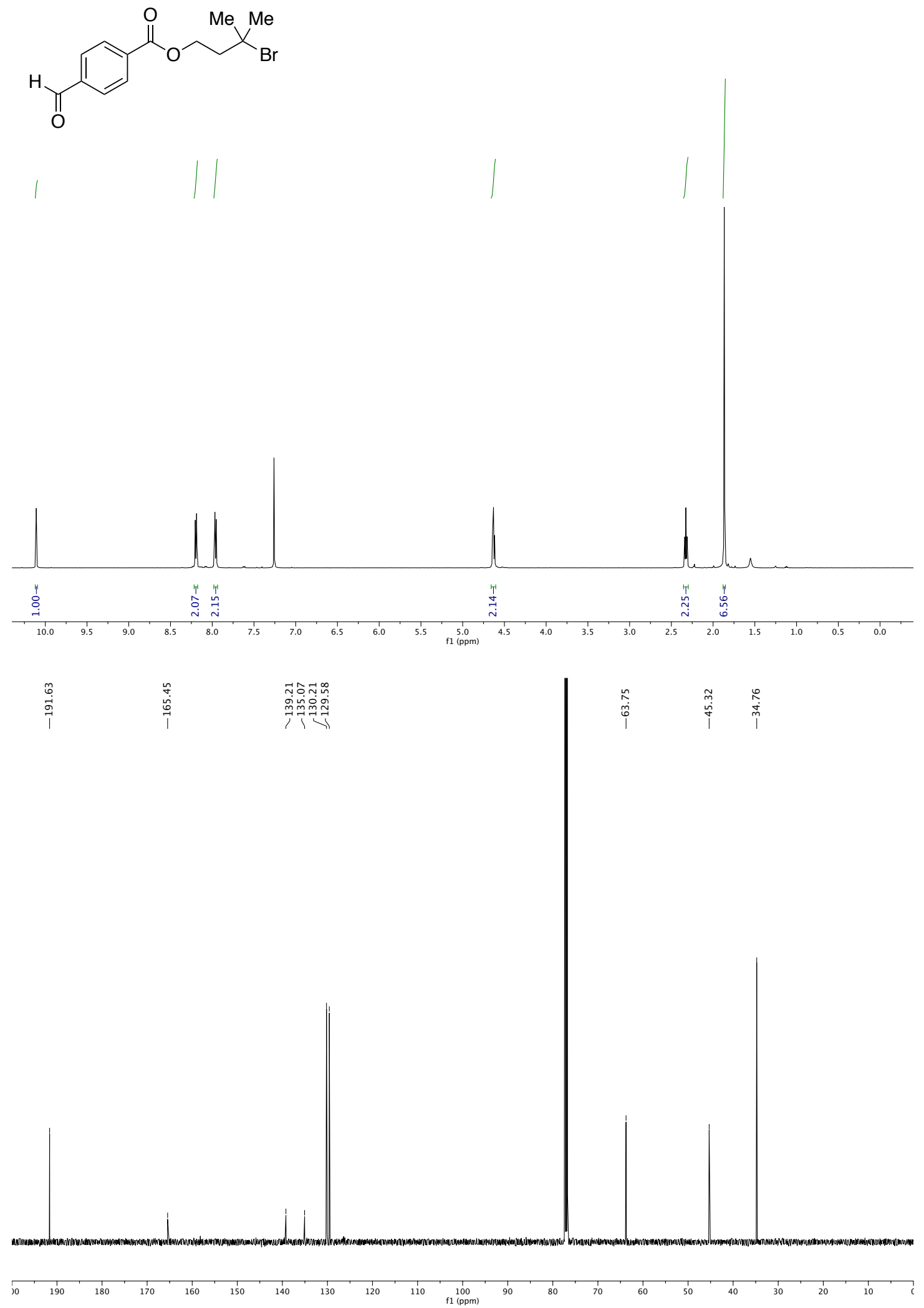
<smiles>CO[C@@H]1C(COC(C)=O)OC(n2ccc(=O)n(CCC(C)Br)c2=O)C1OC(C)C</smiles>
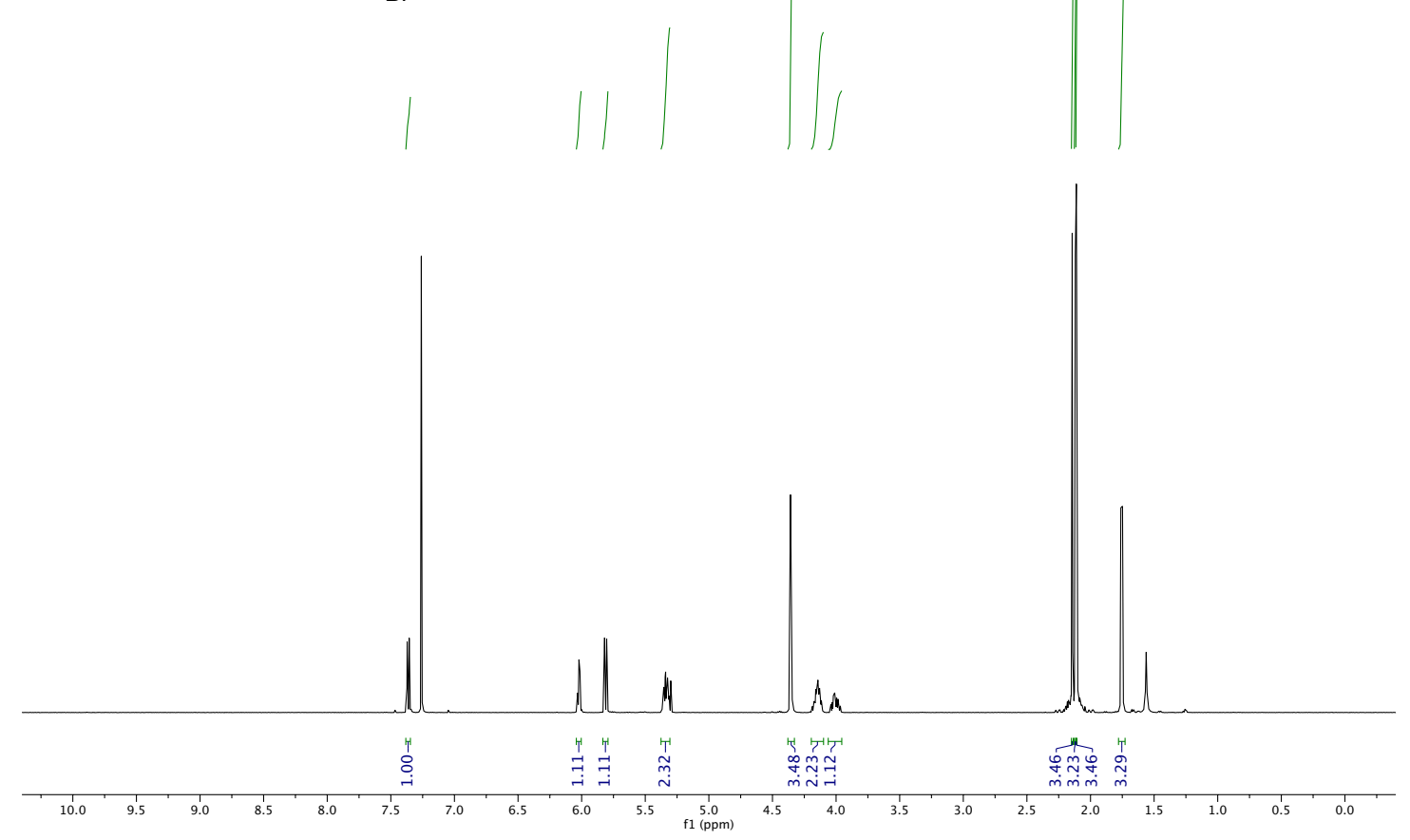

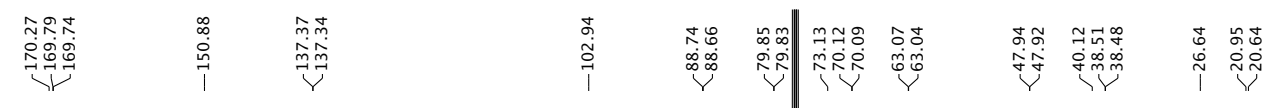

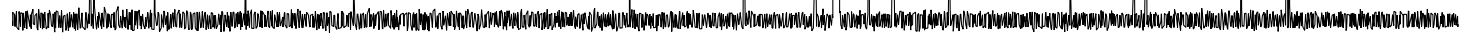

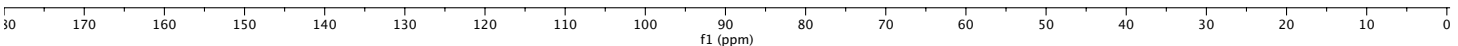


<smiles>O=C1CC2CC(F)CCN12</smiles>
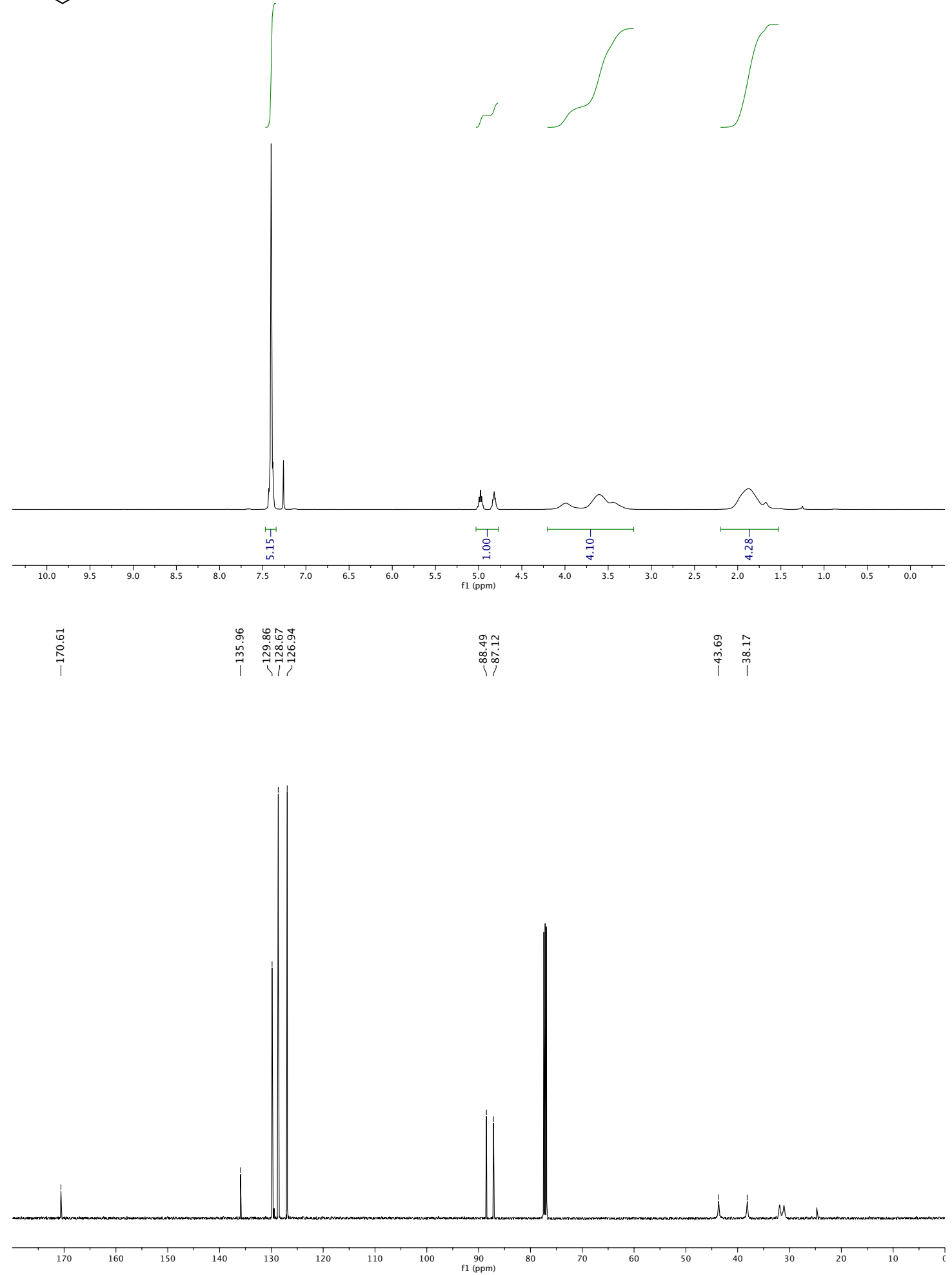
ํํㅇำำำ

$\infty_{\infty}^{\infty} \infty \infty_{\infty}^{\infty} \infty \infty$

过北

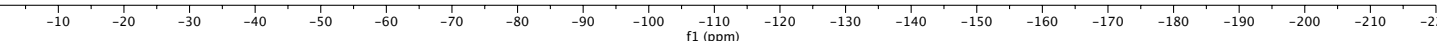




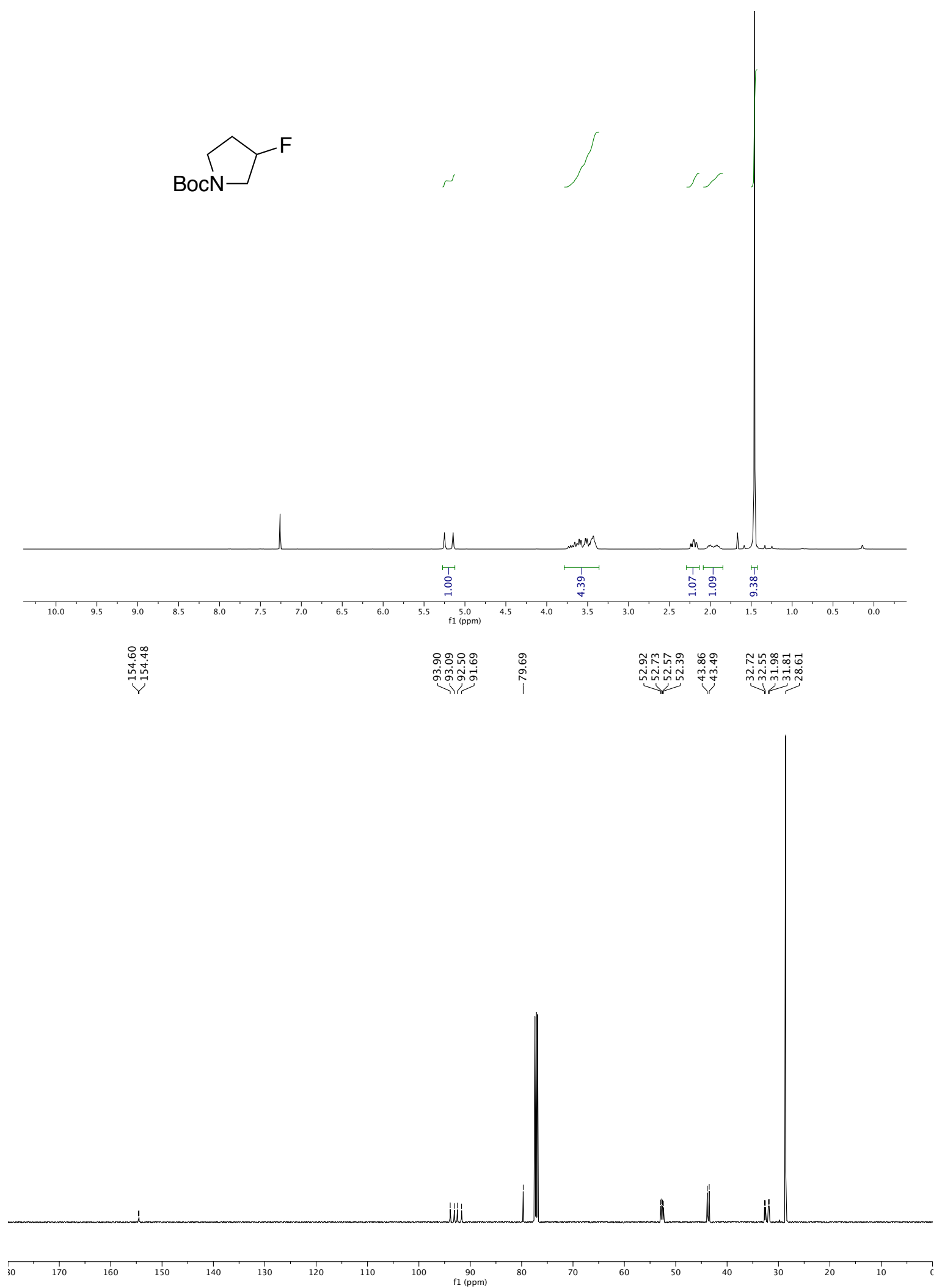




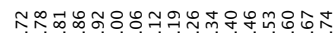

ดOด

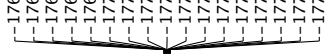

MuN W. 

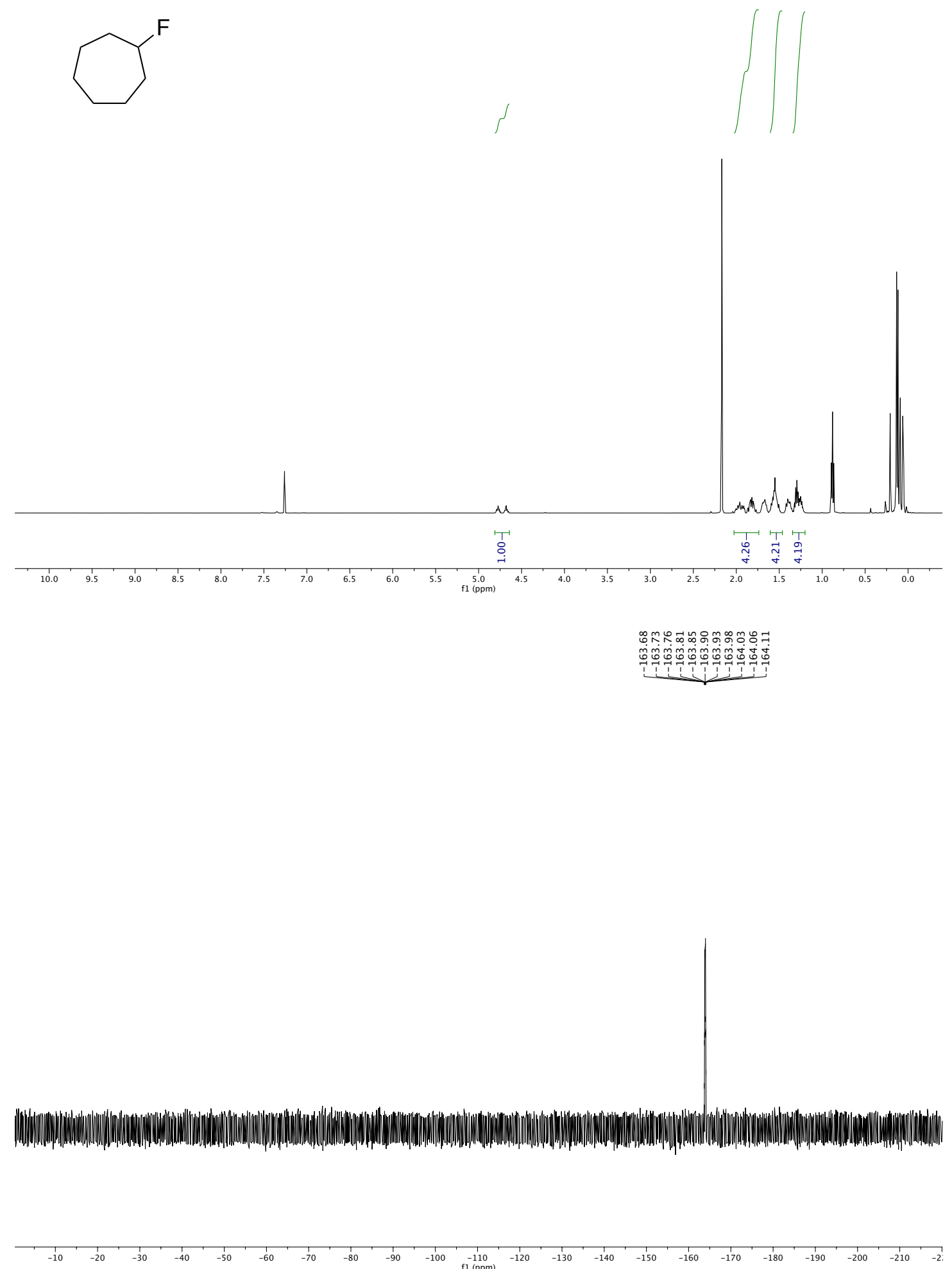


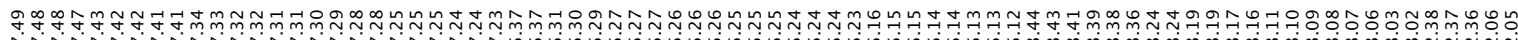

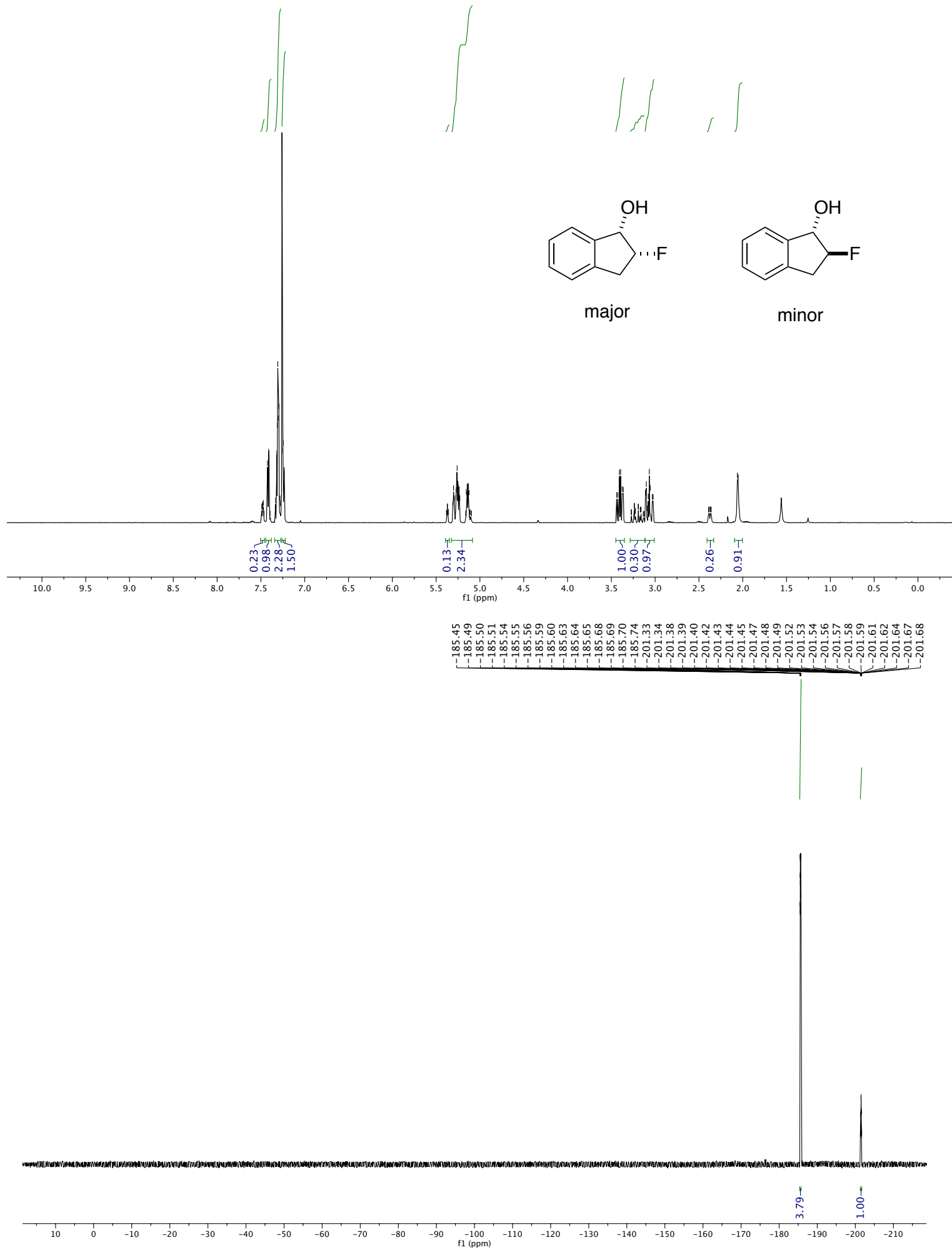



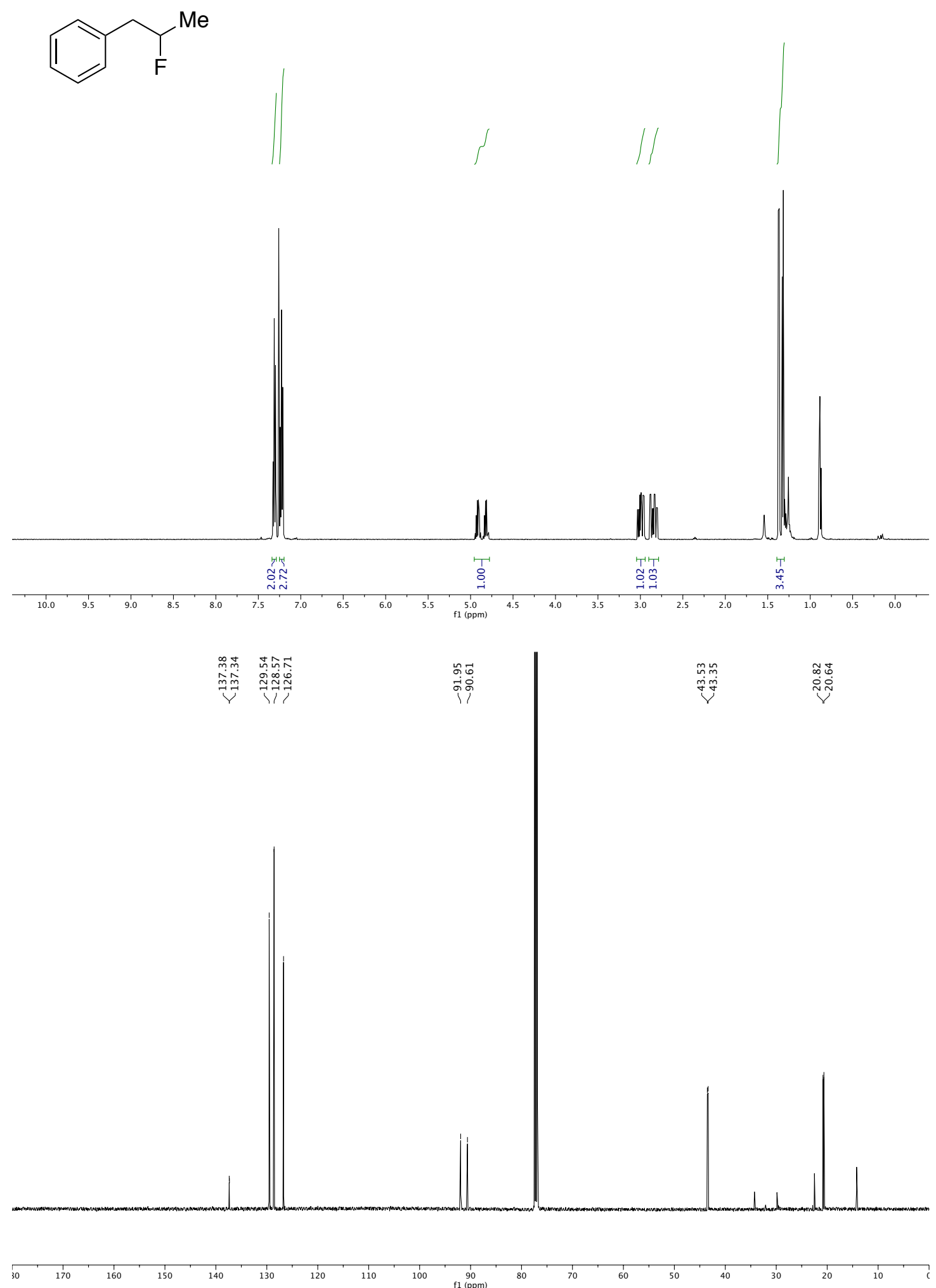

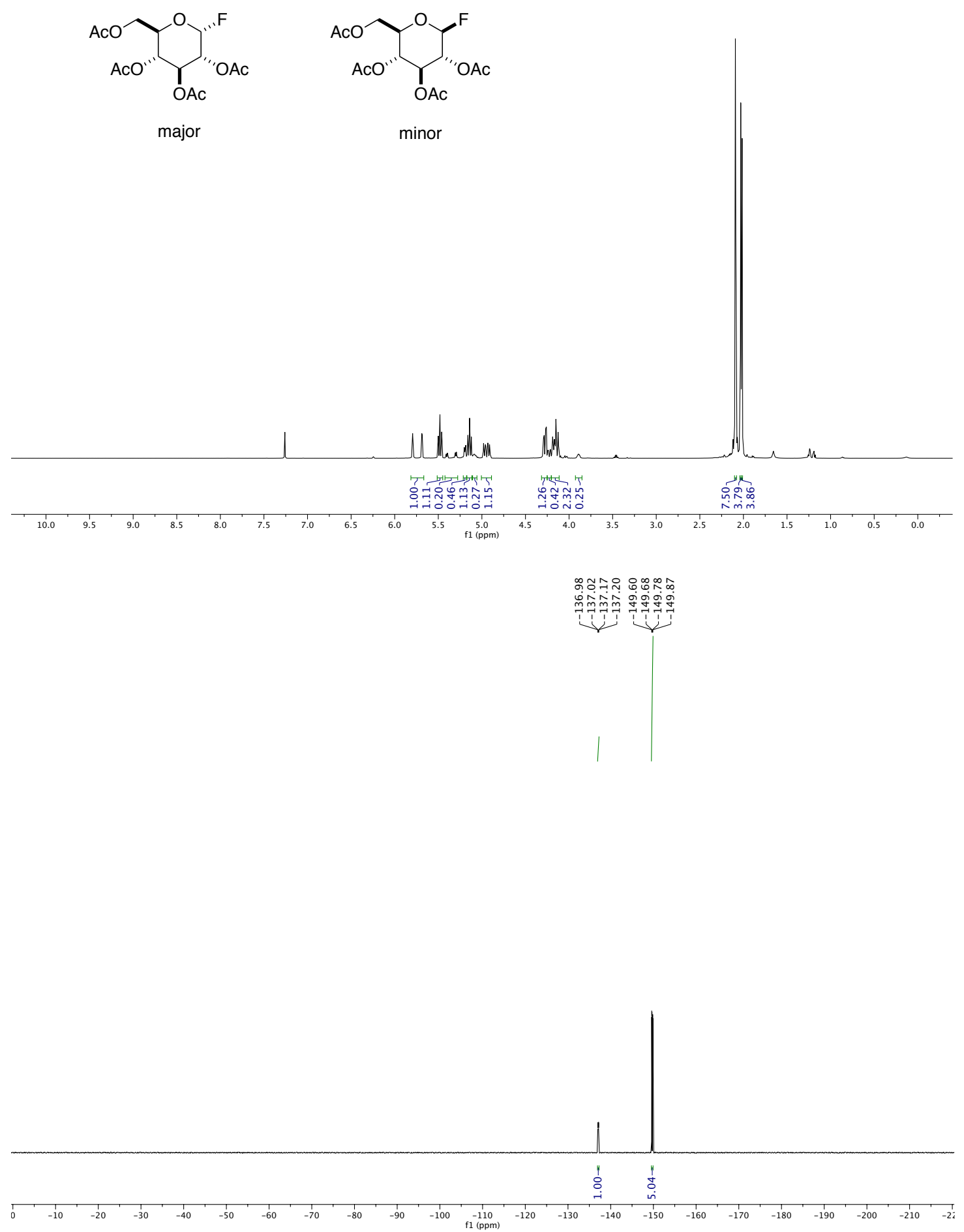


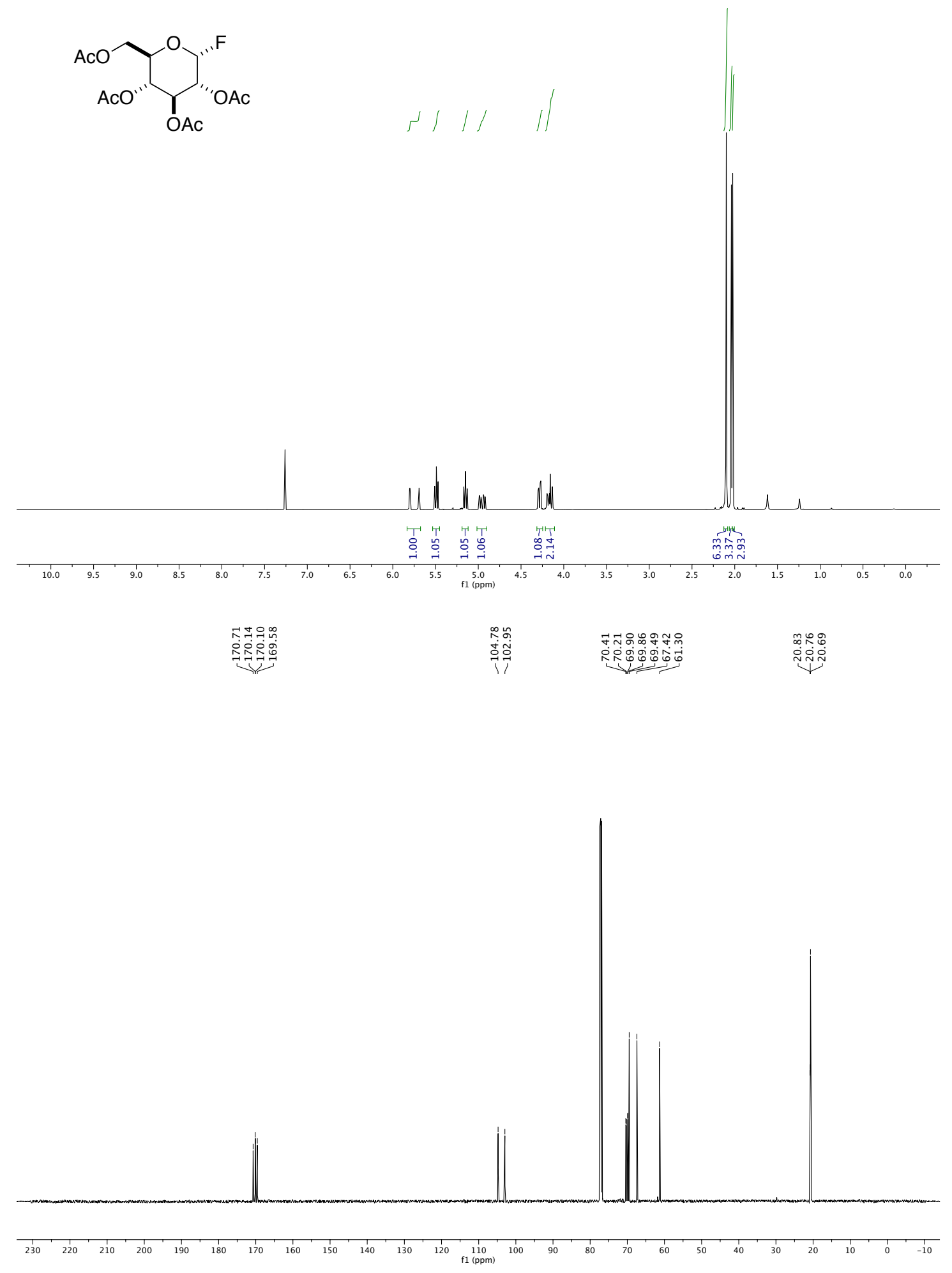



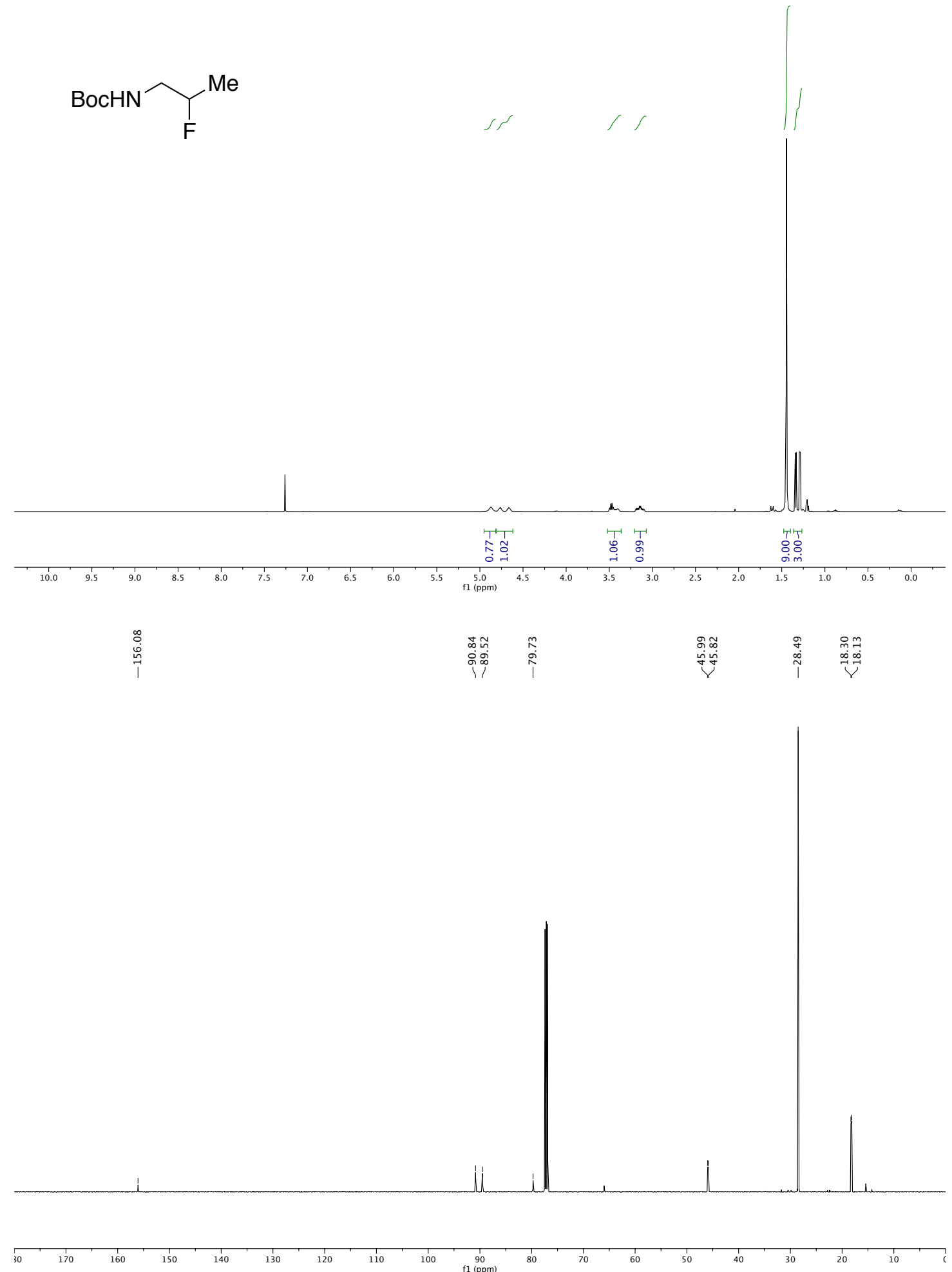


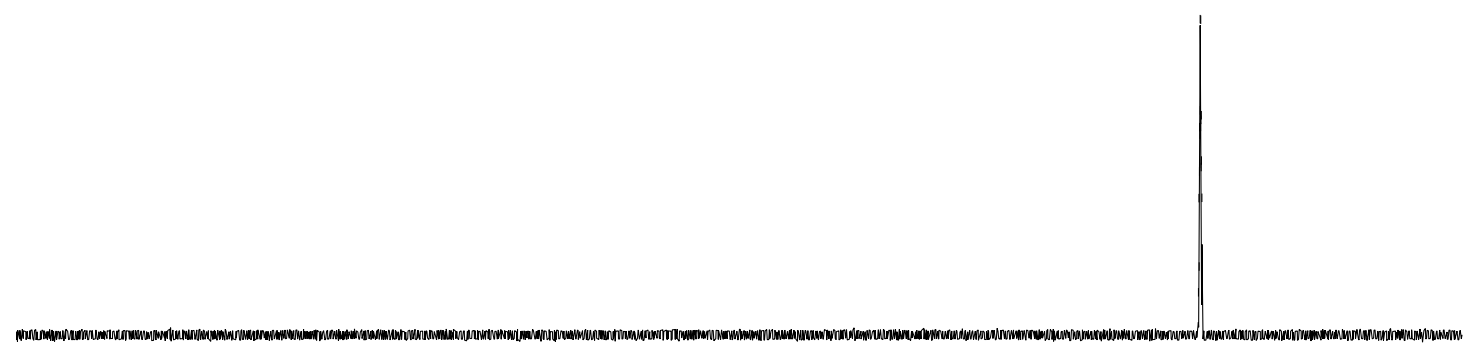



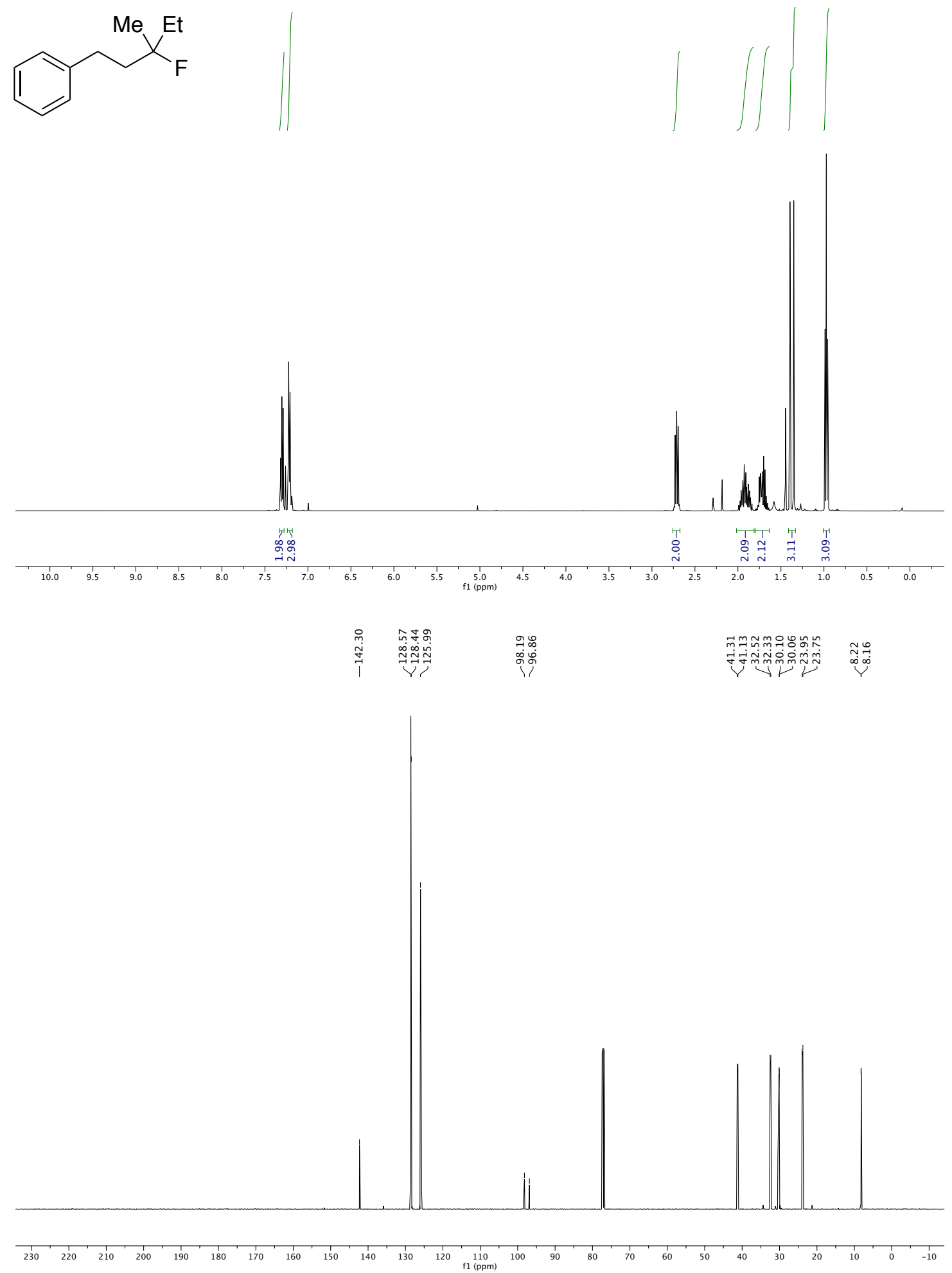


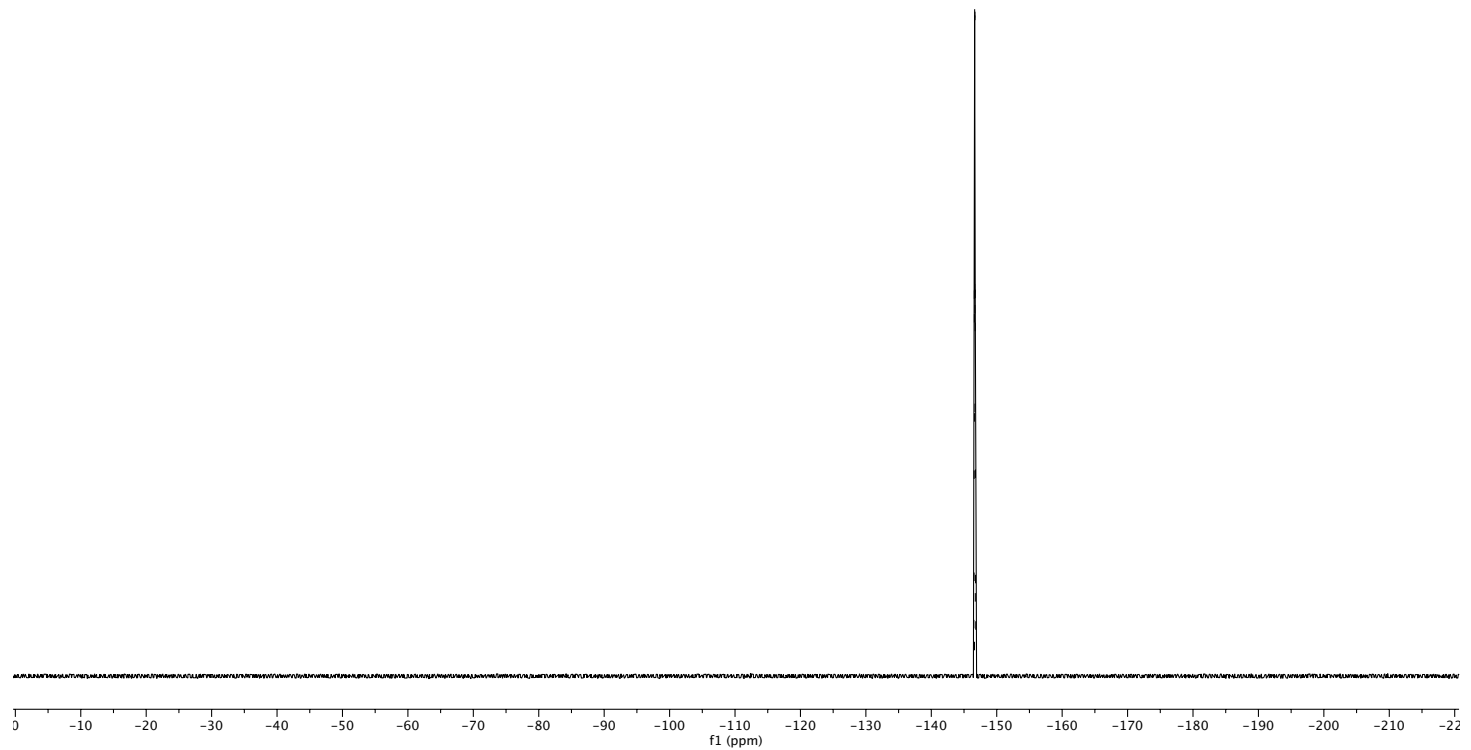


<smiles>CC(C)(F)CCOC(=O)c1ccc(Cl)cc1</smiles>
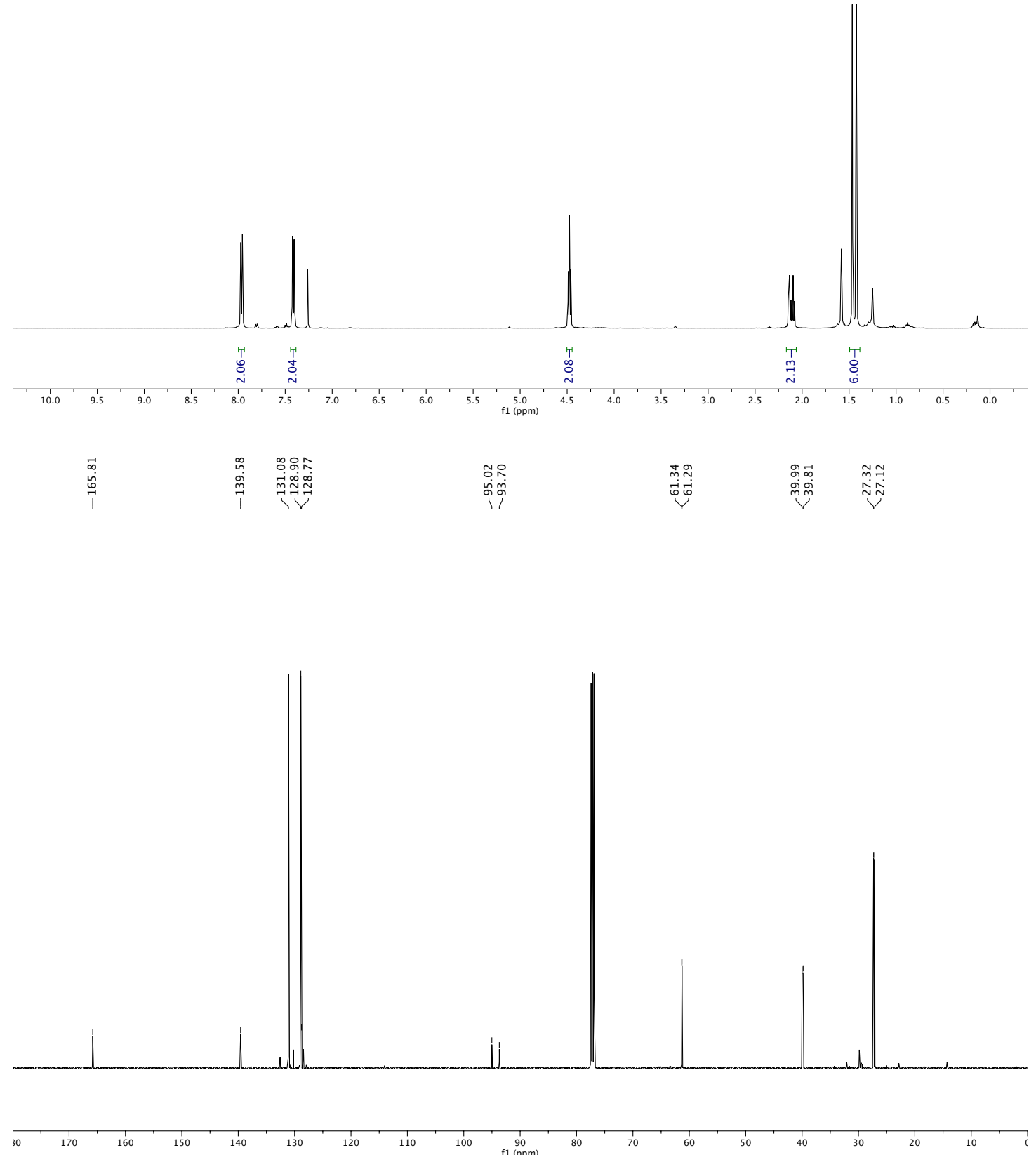


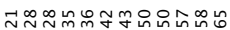

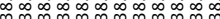

1
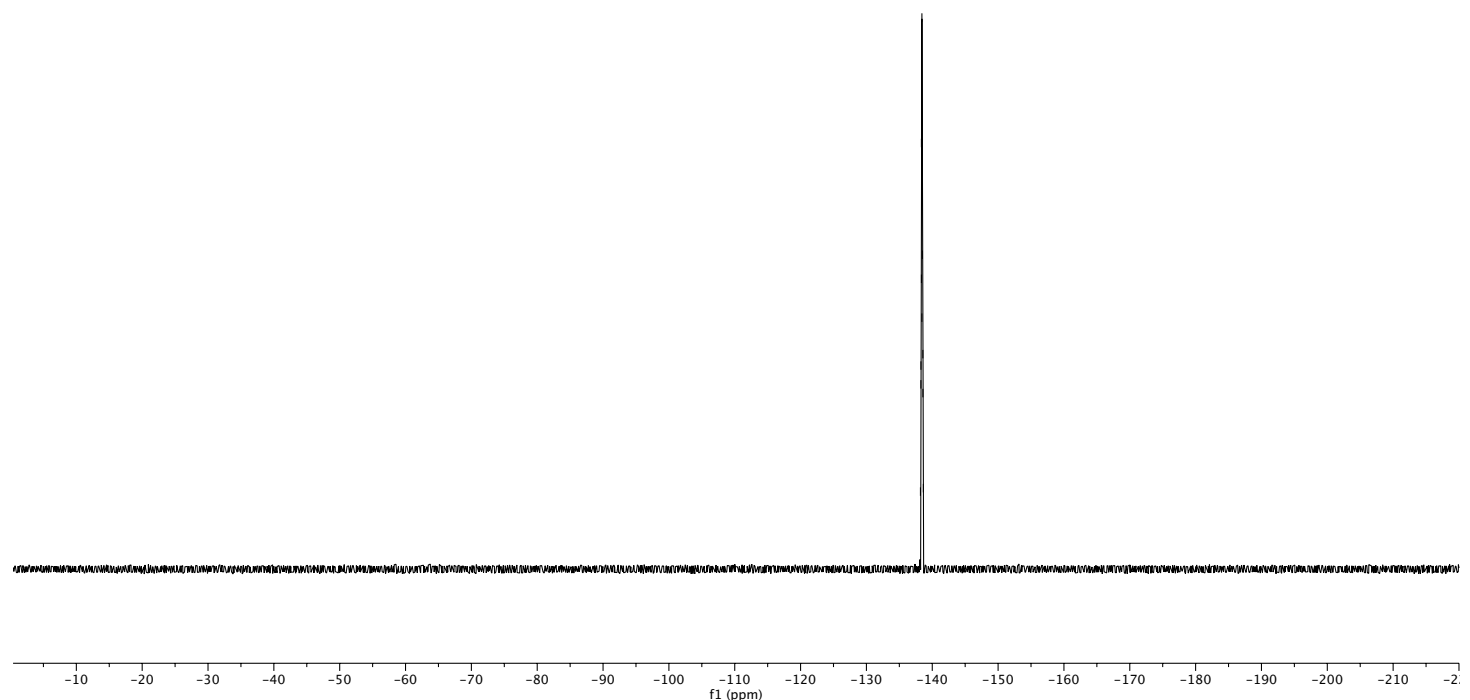

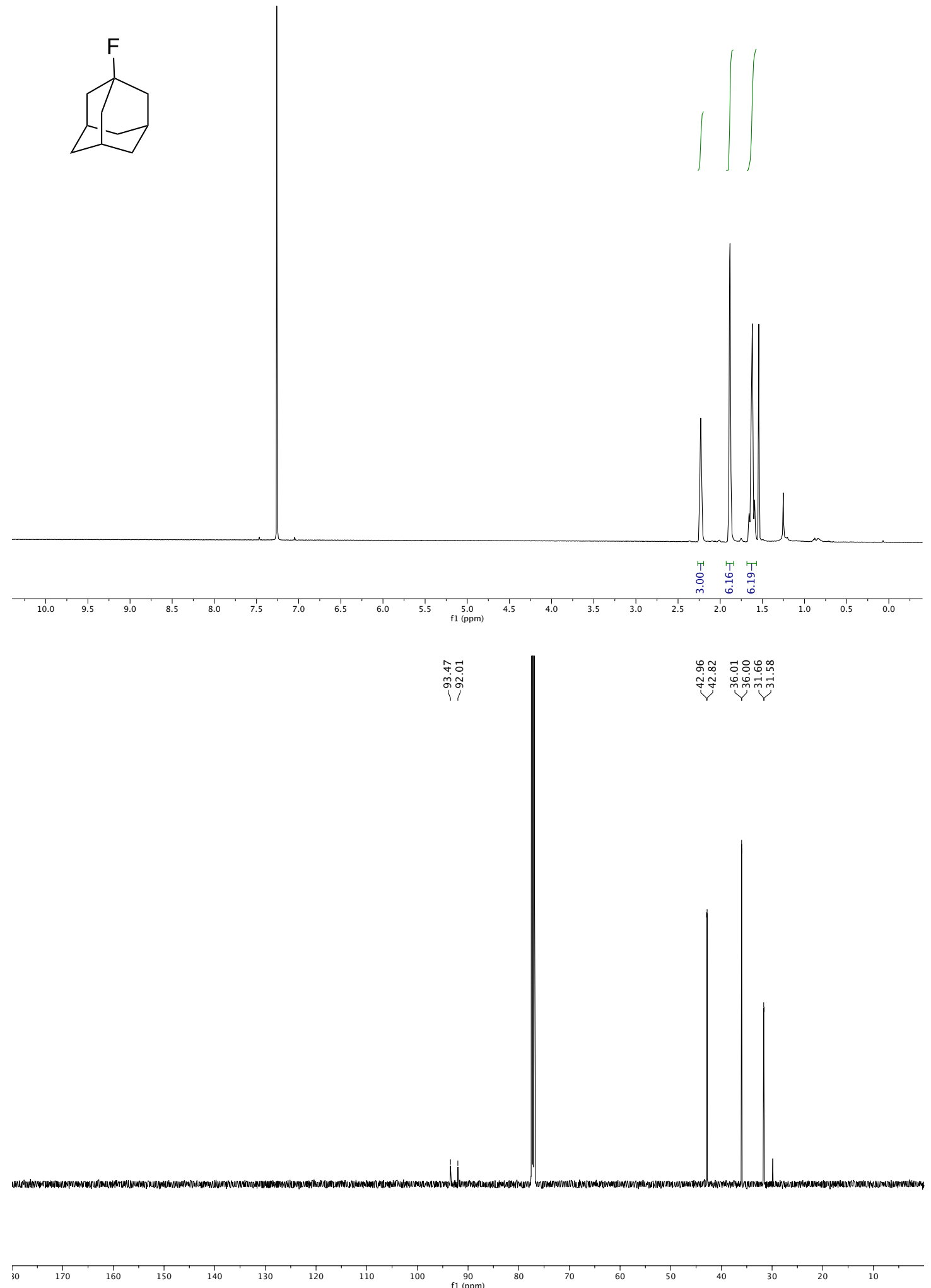


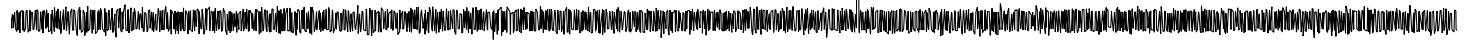

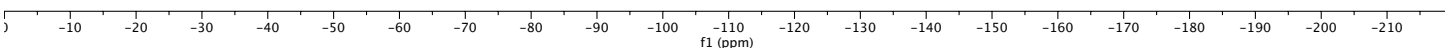




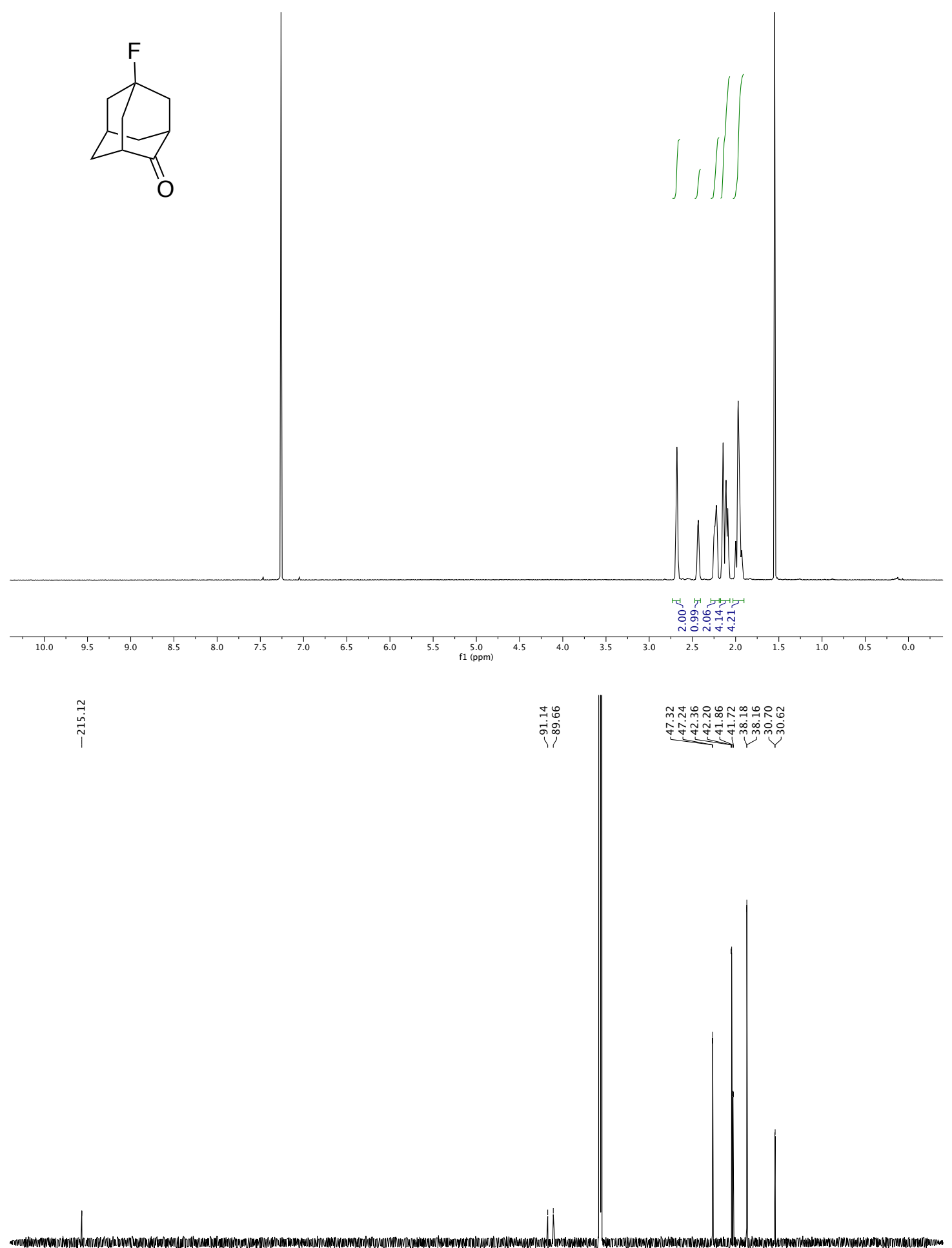

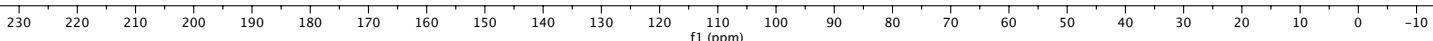




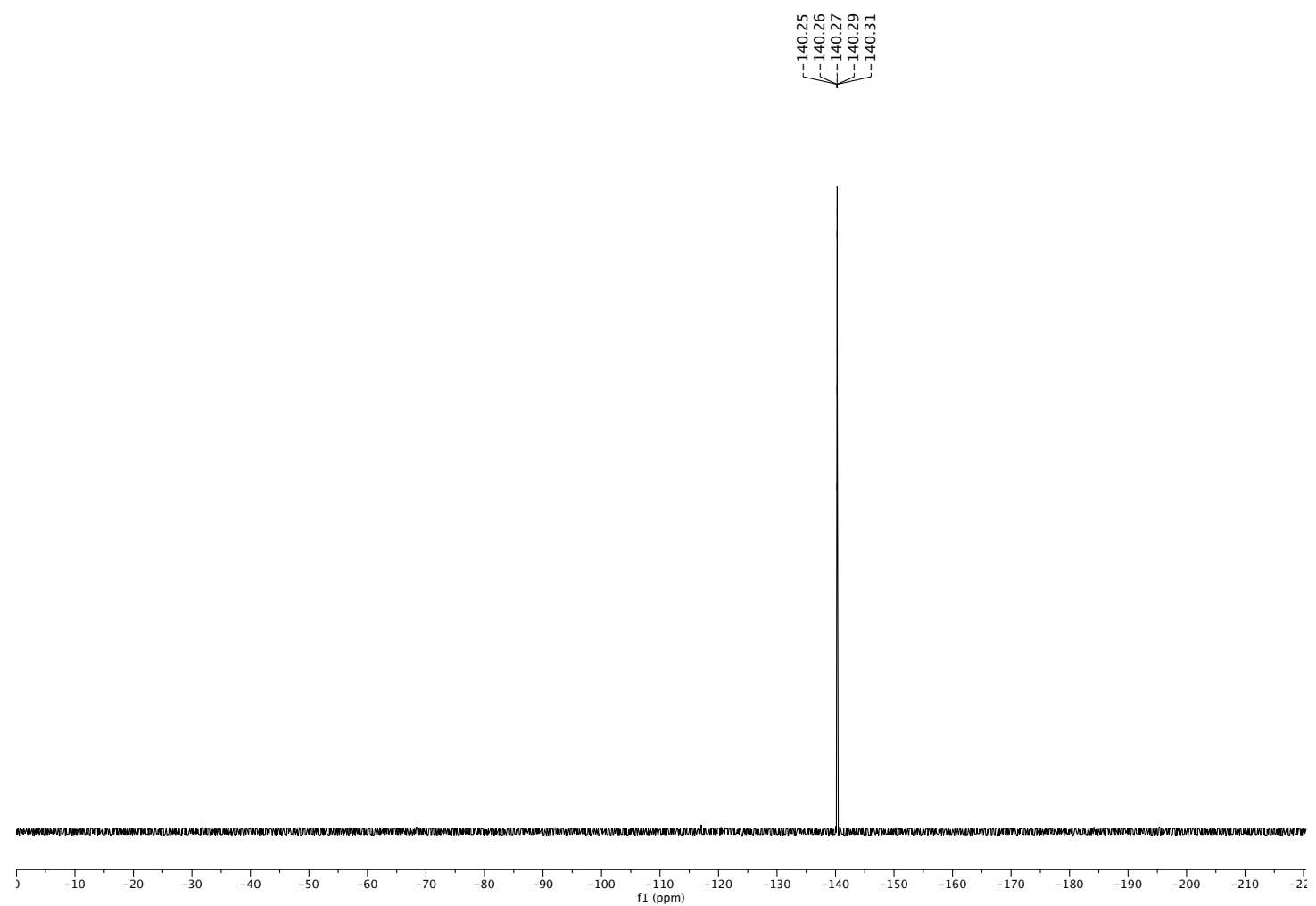




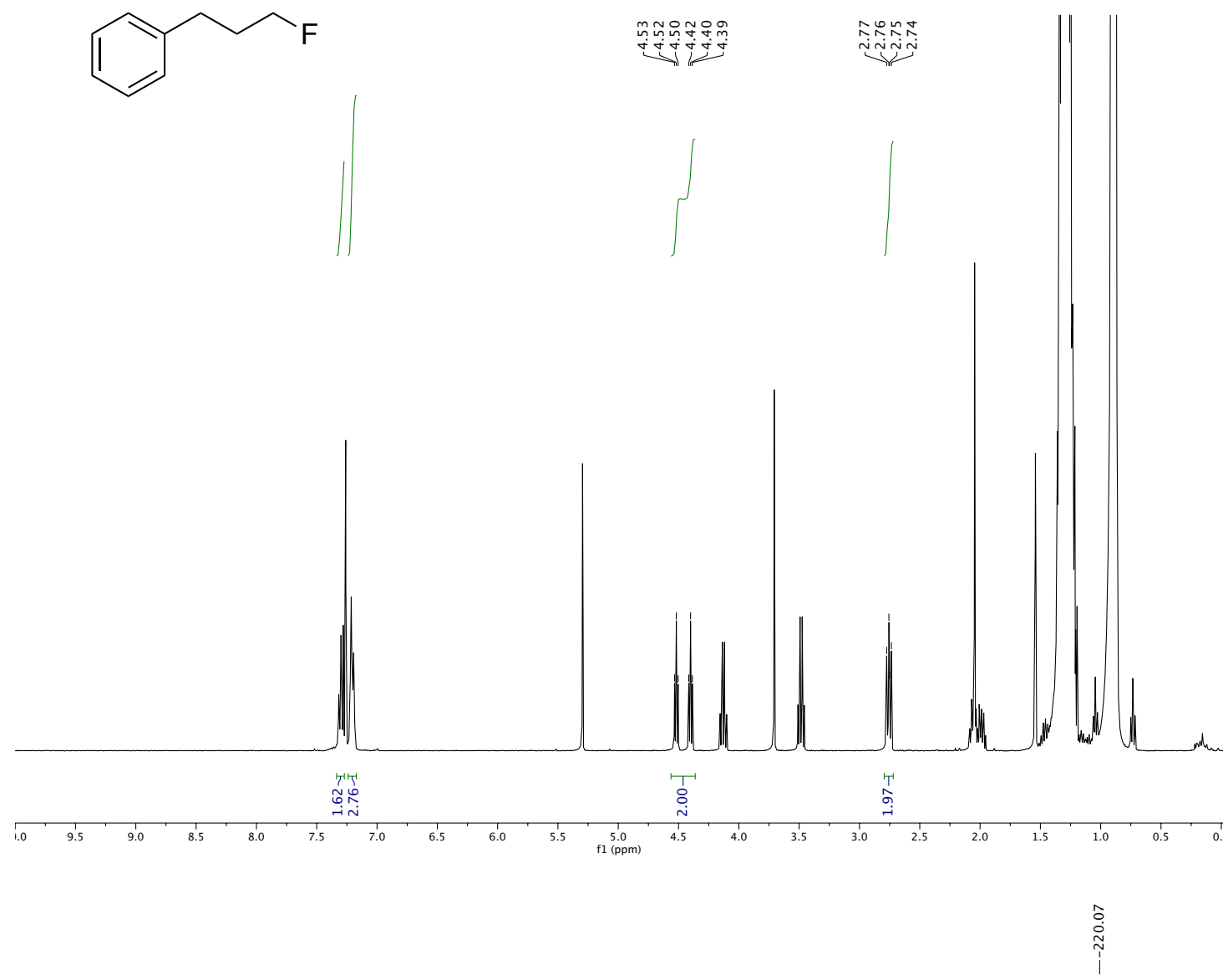

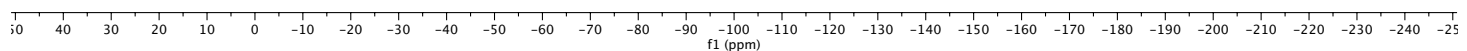


monm

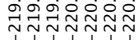

过议
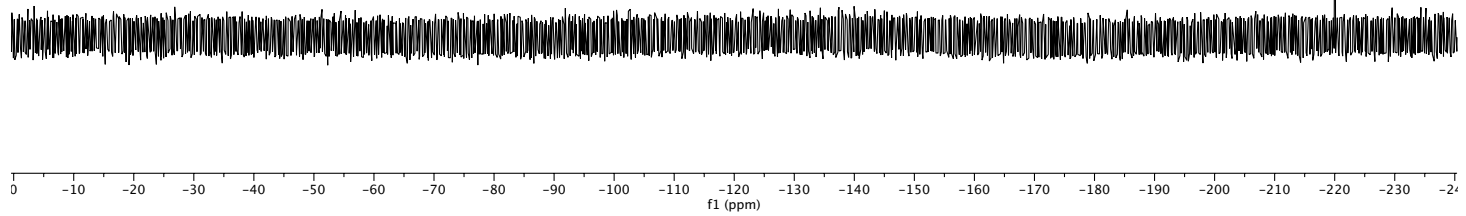
<smiles>COC(=O)c1ccc(C(C)F)cc1</smiles>
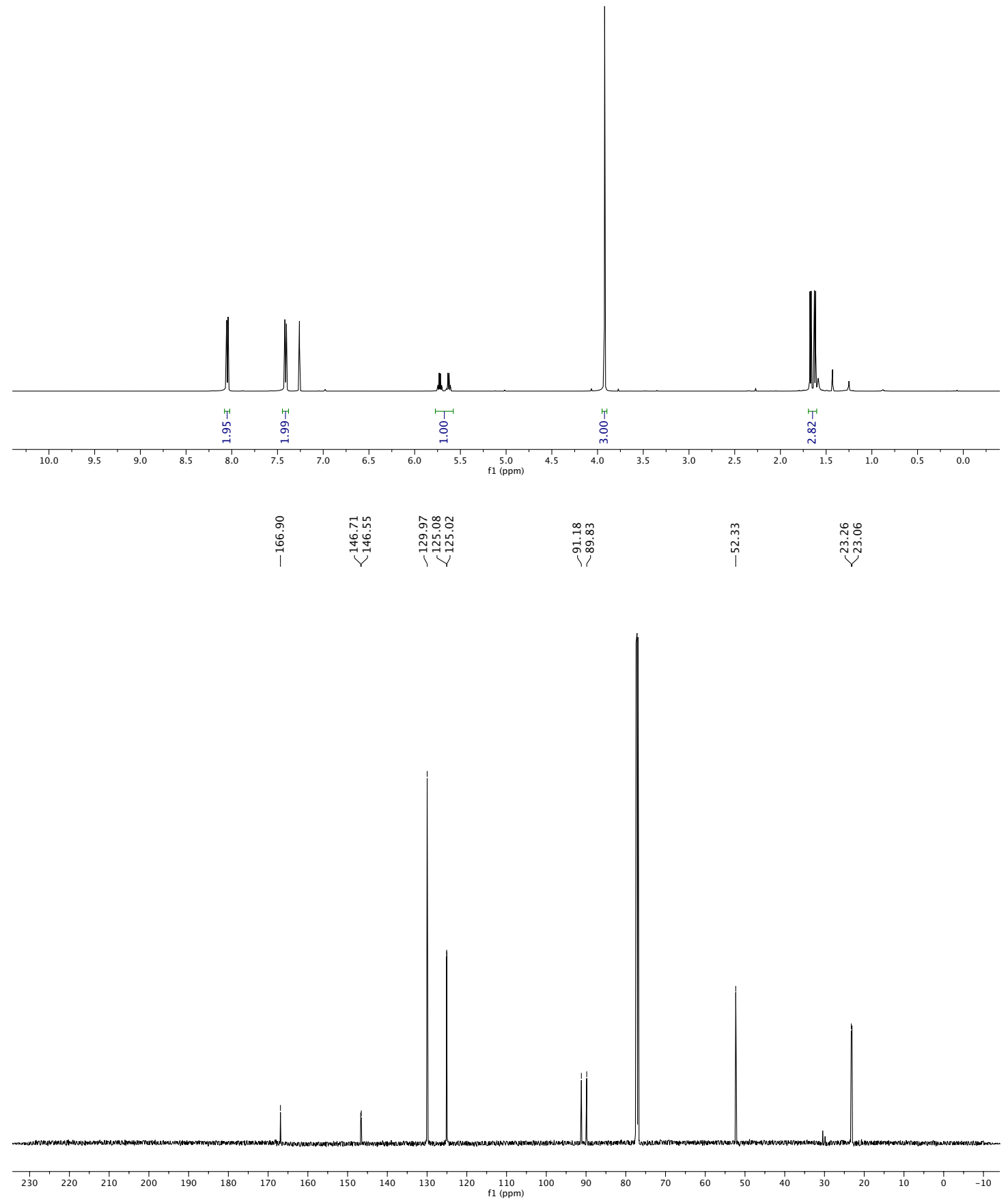


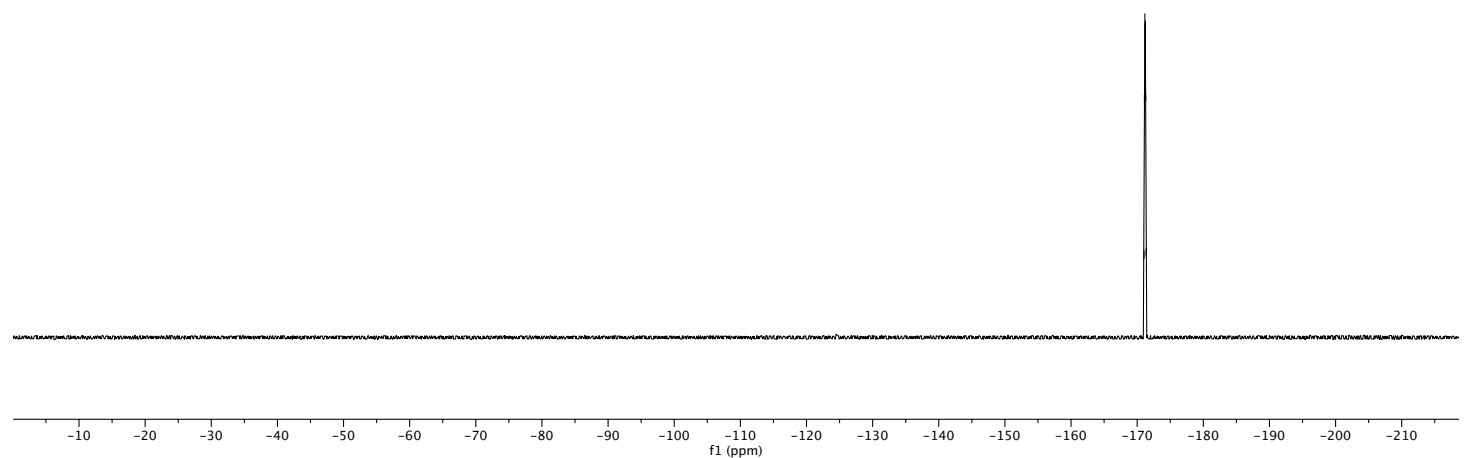



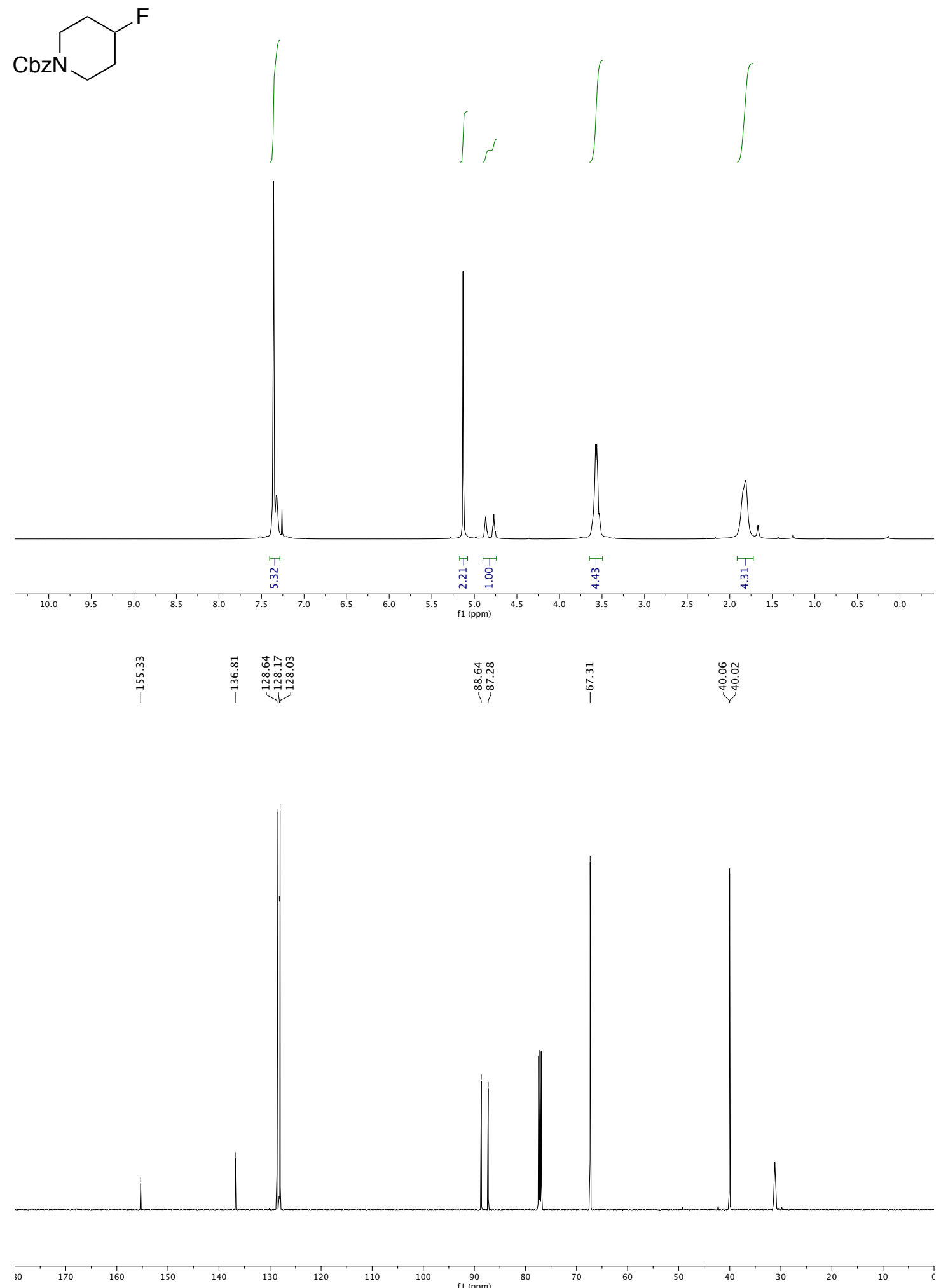


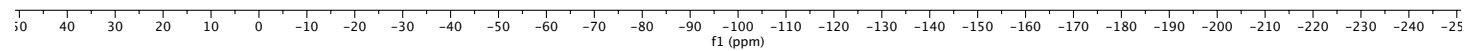



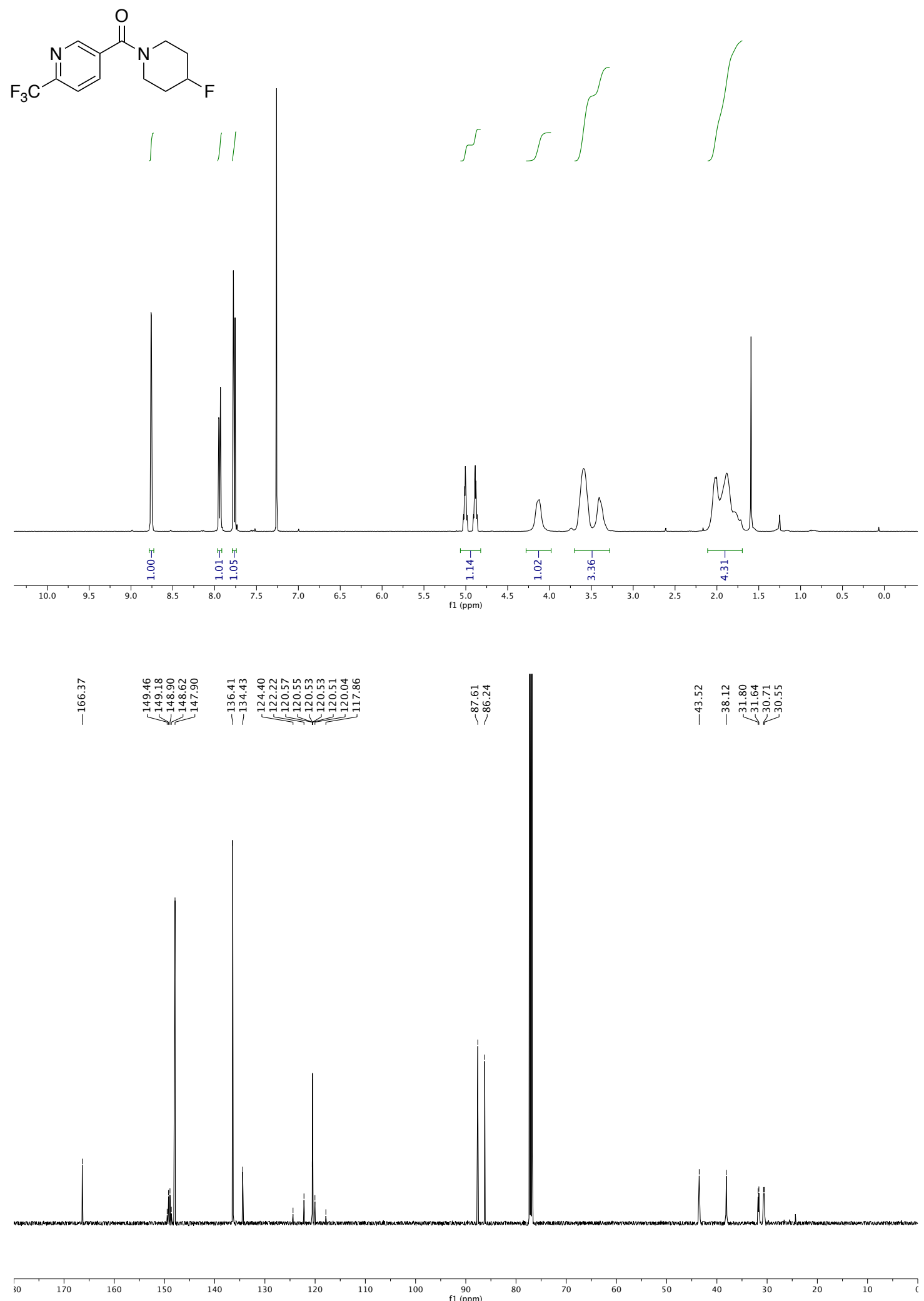


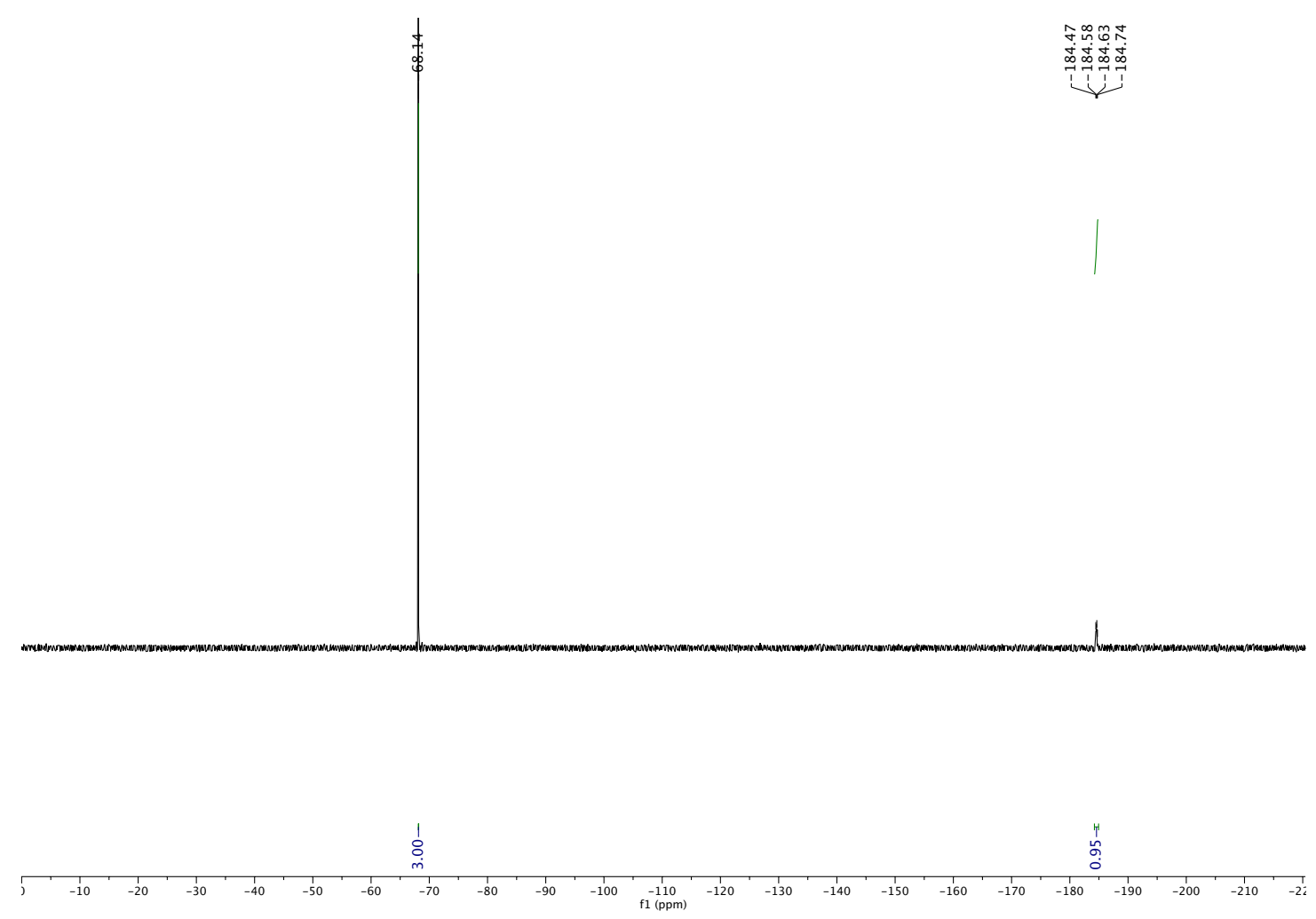



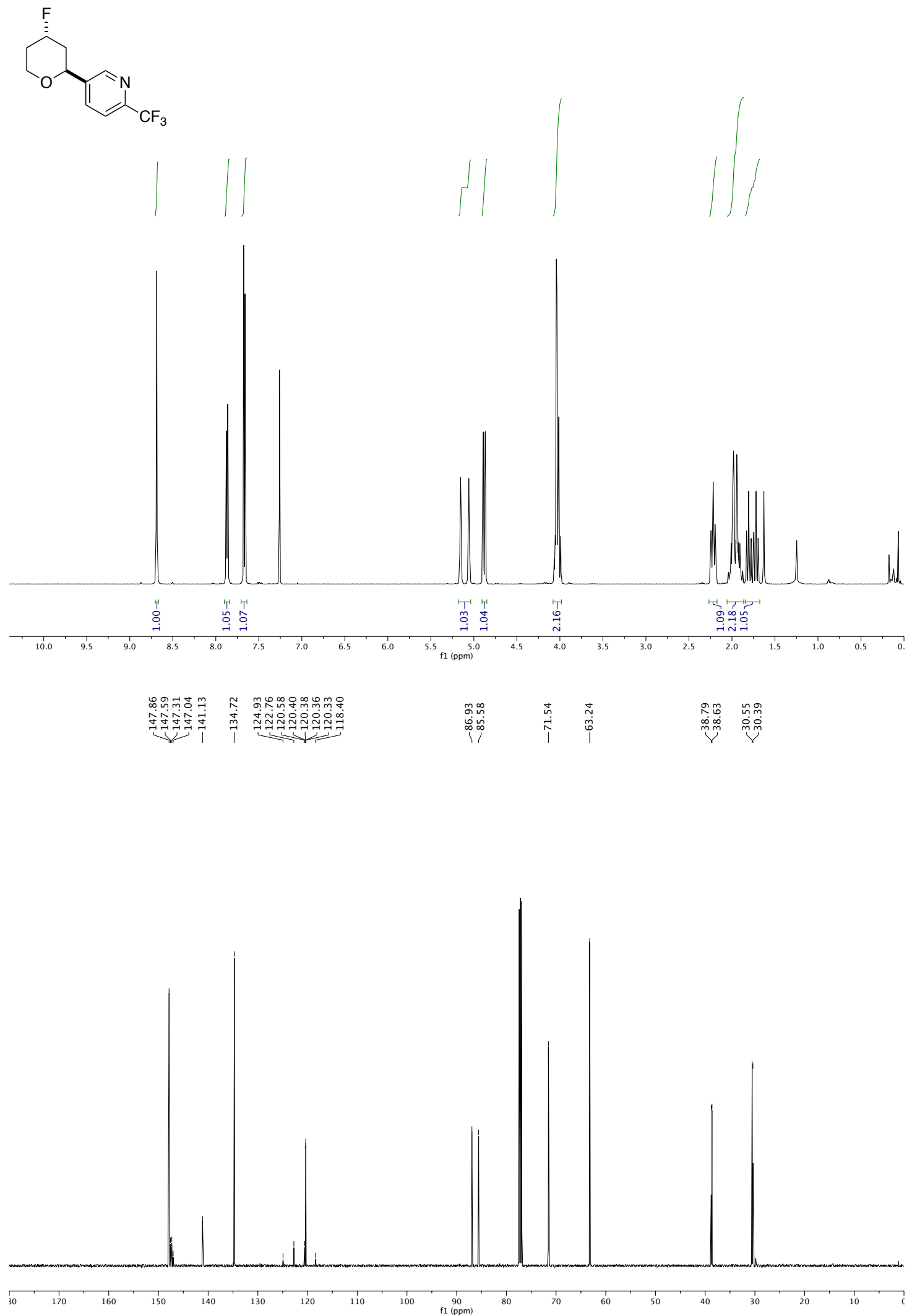


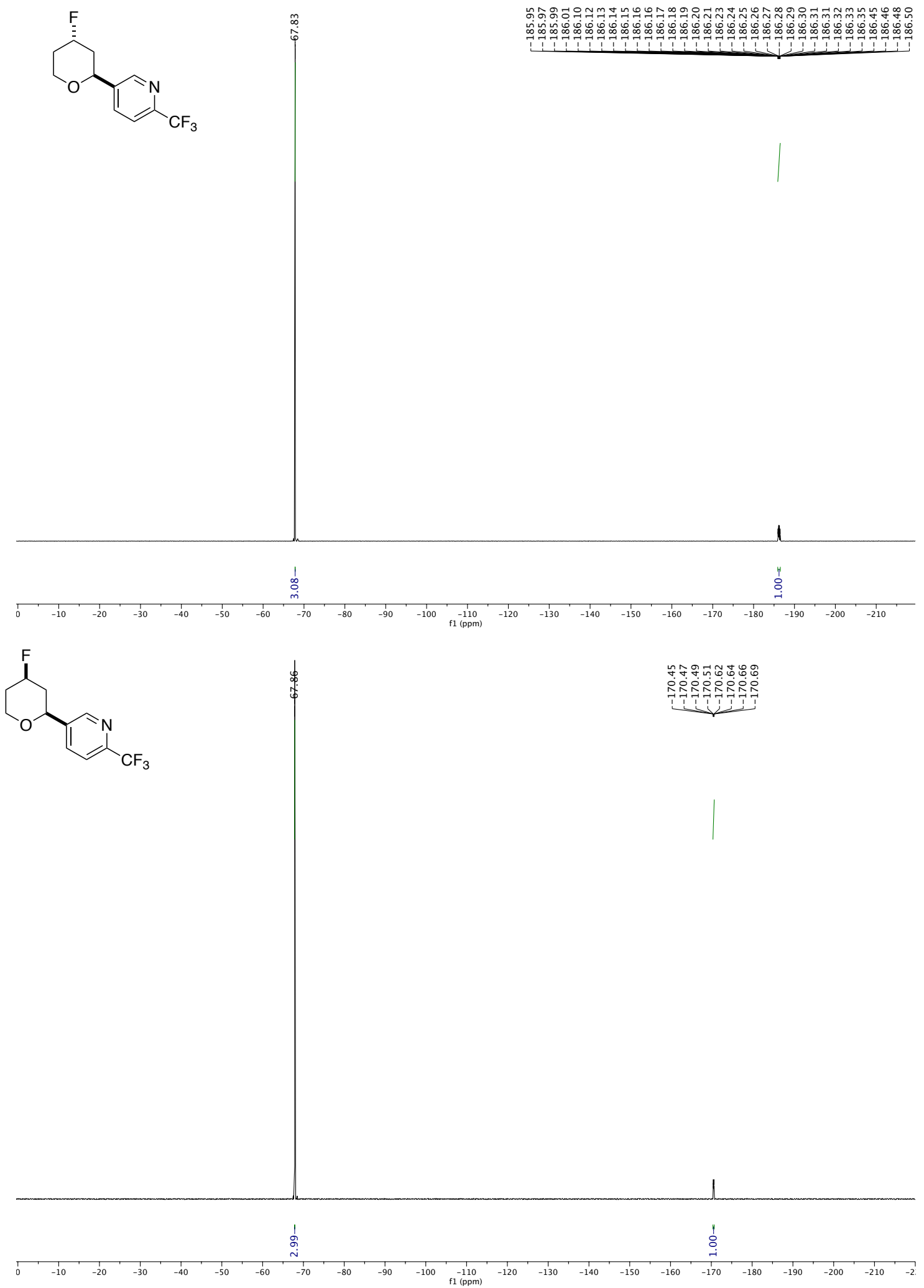




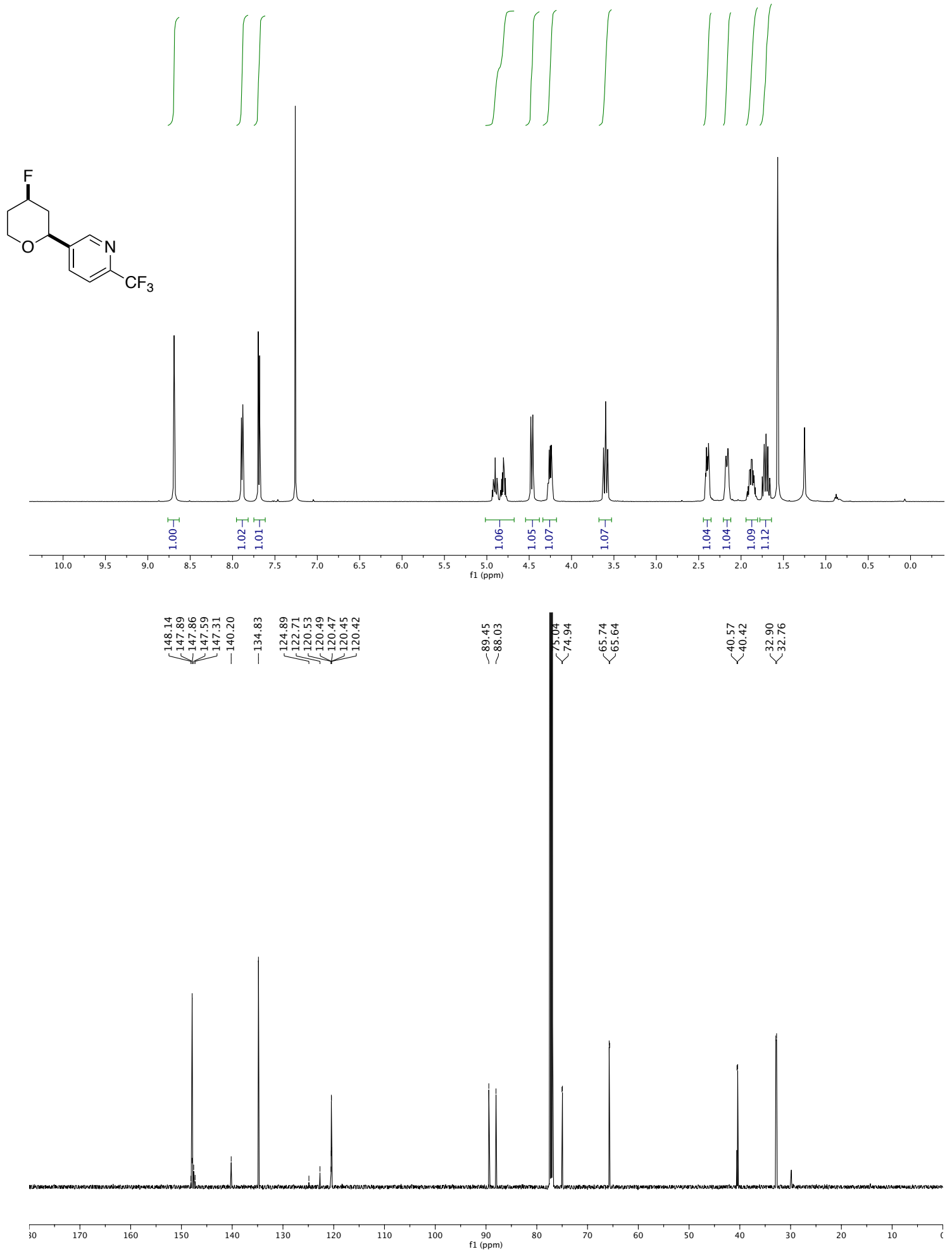



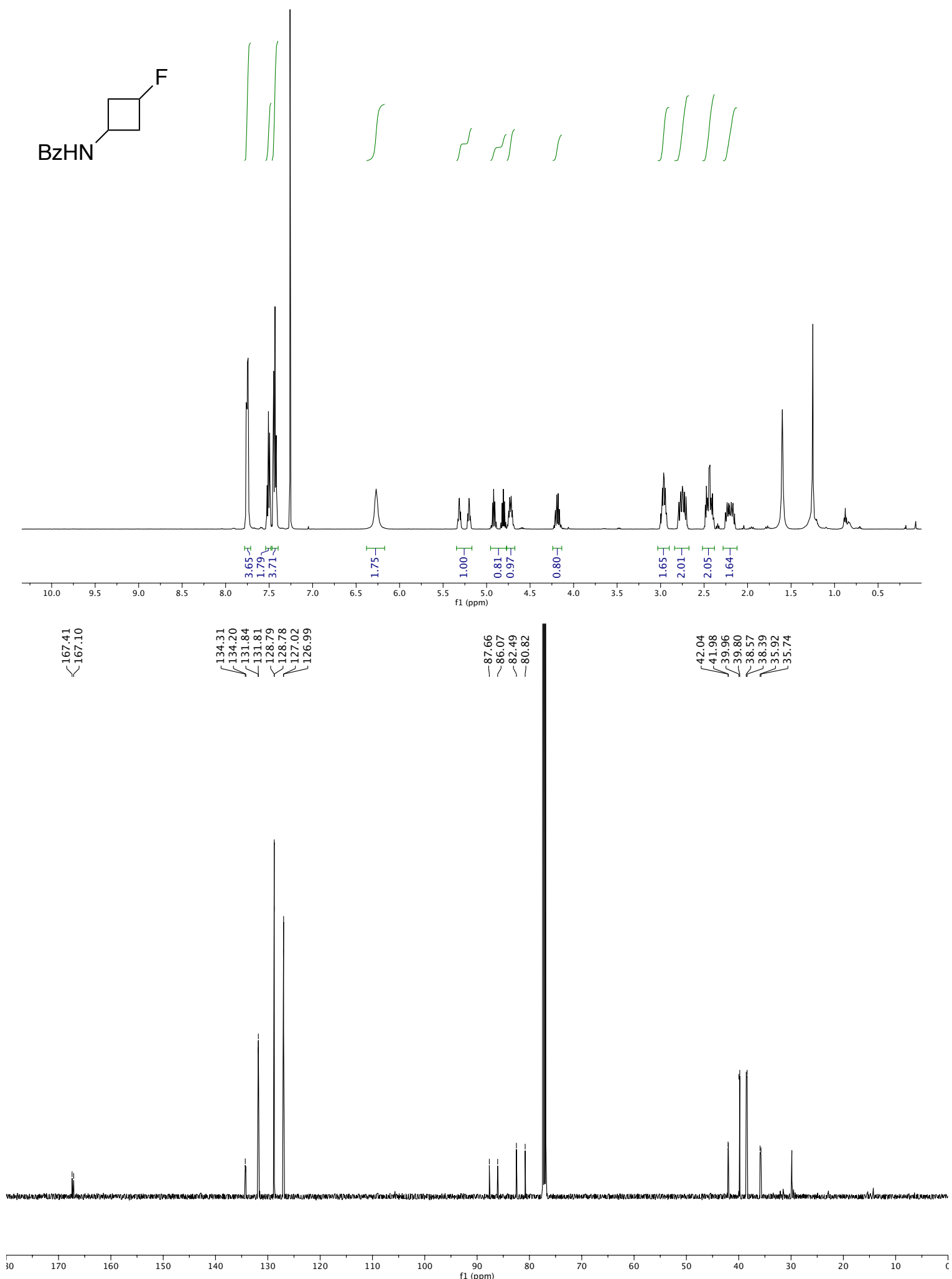


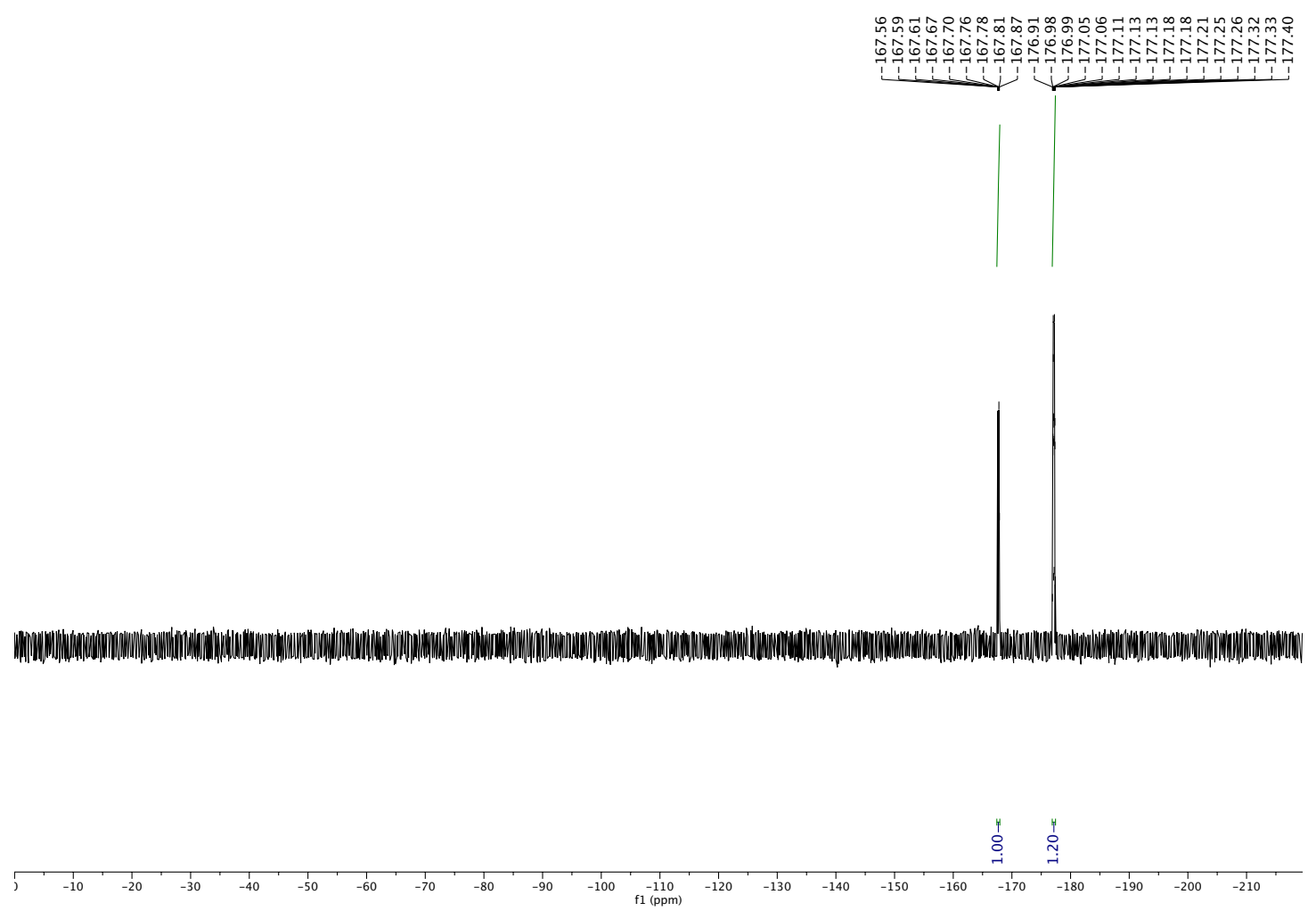



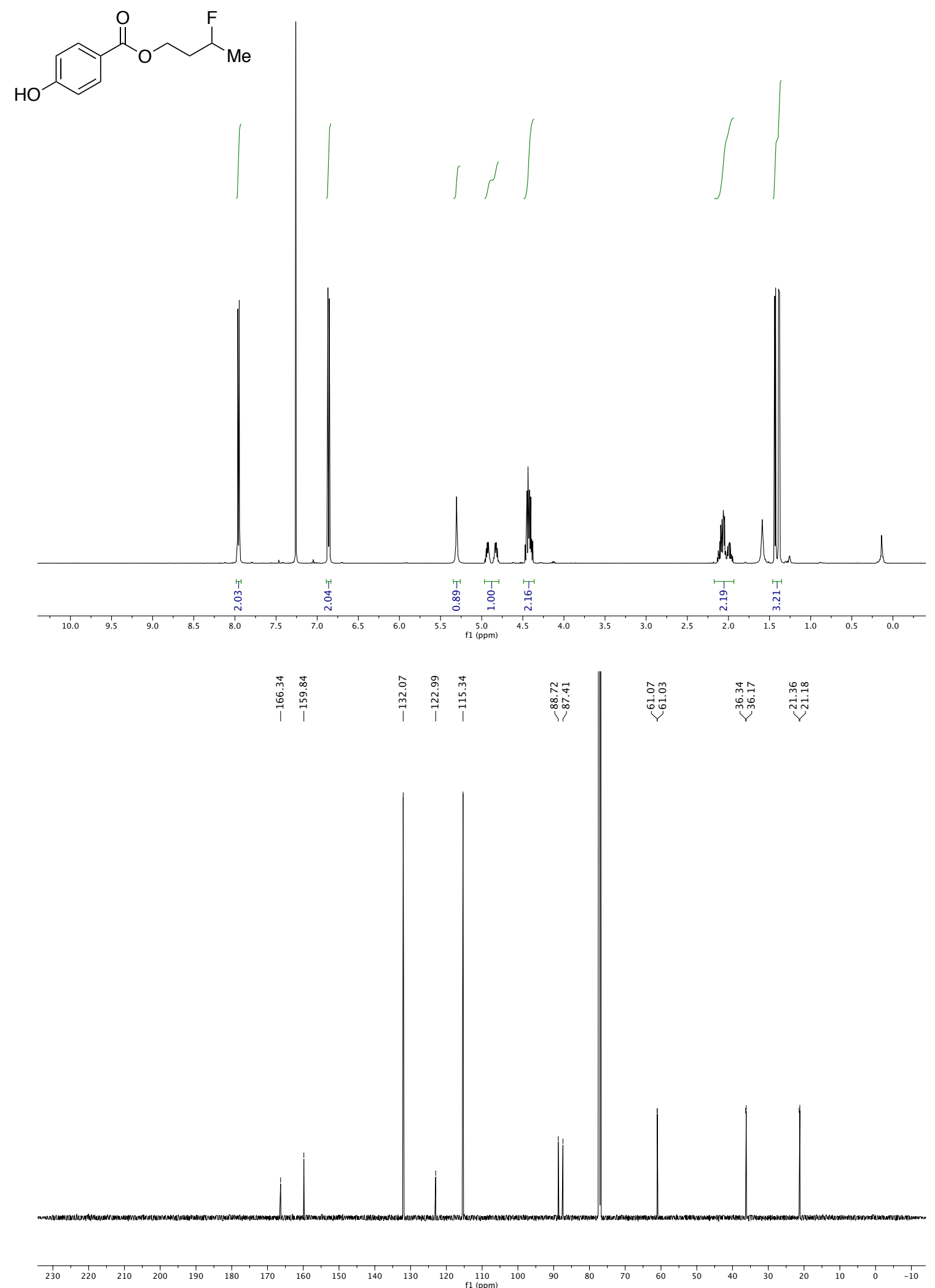

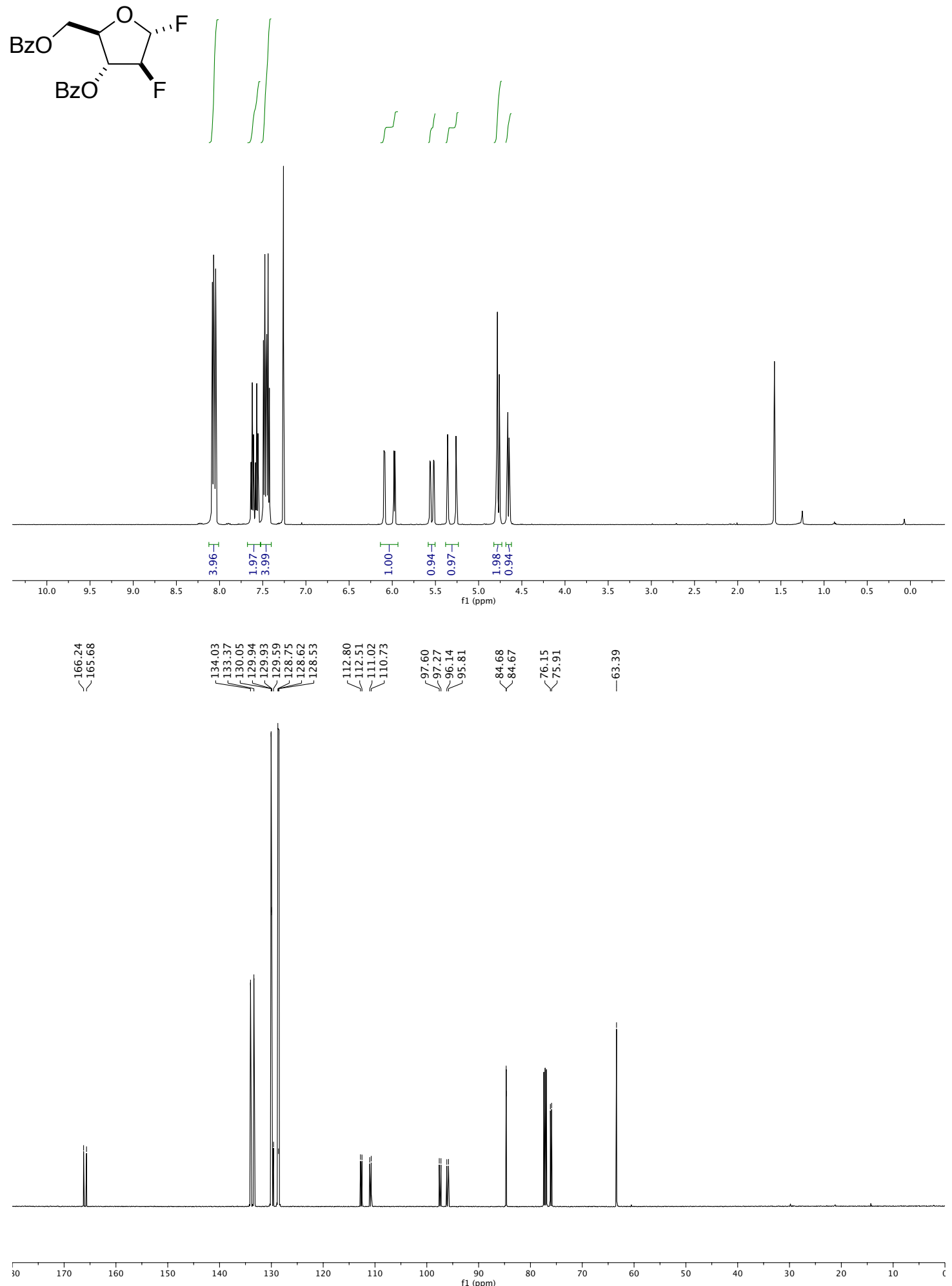


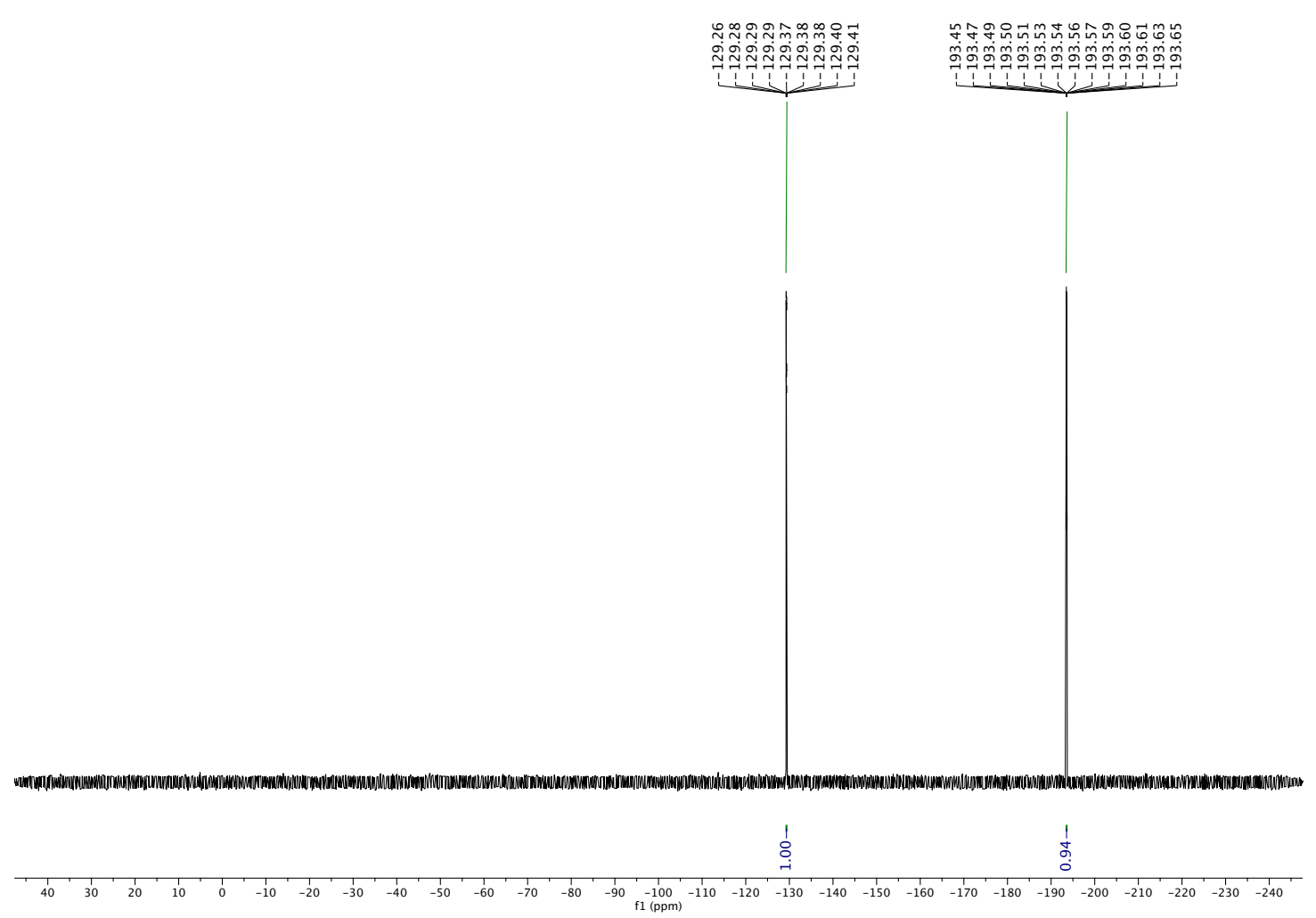



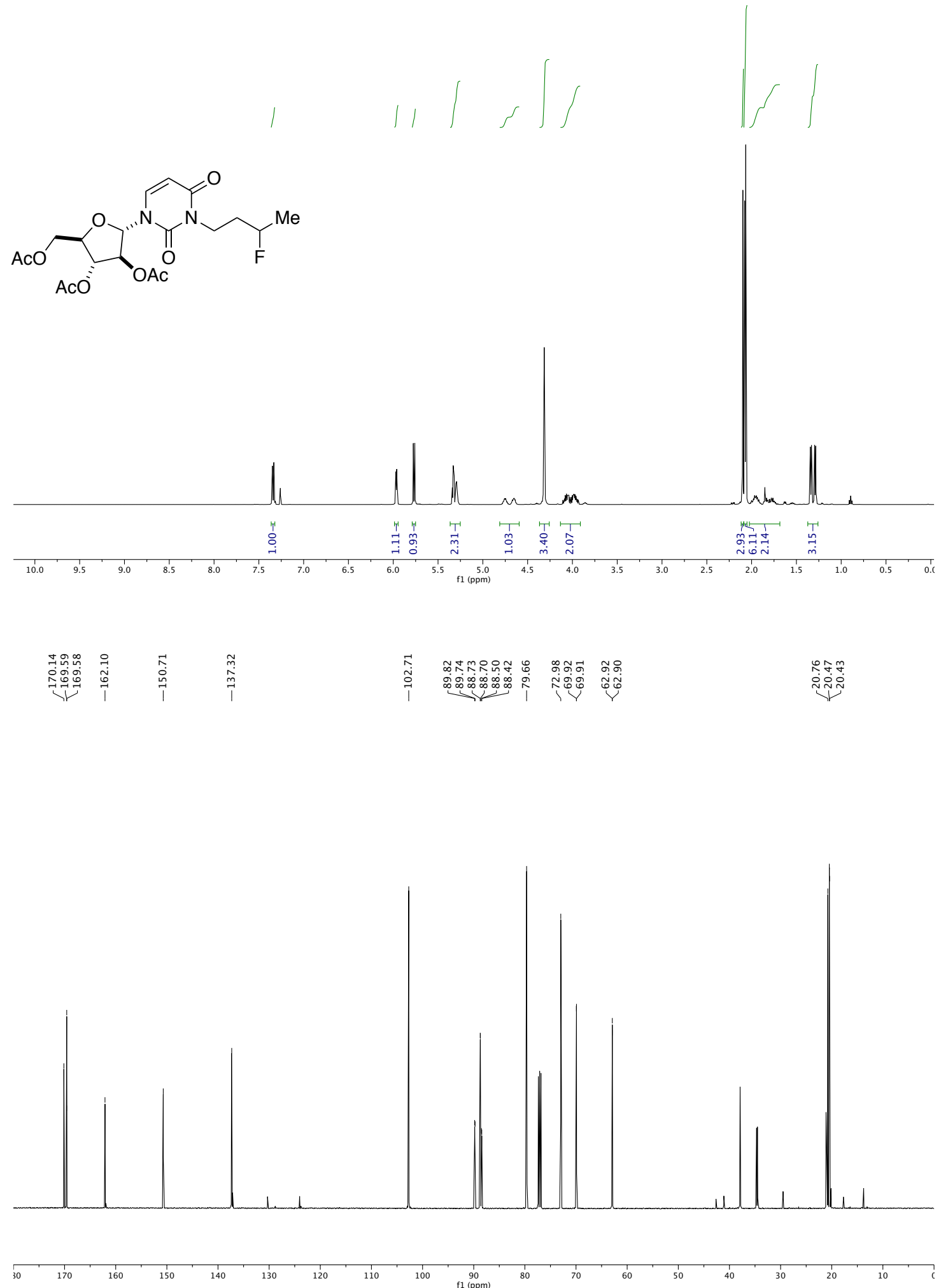


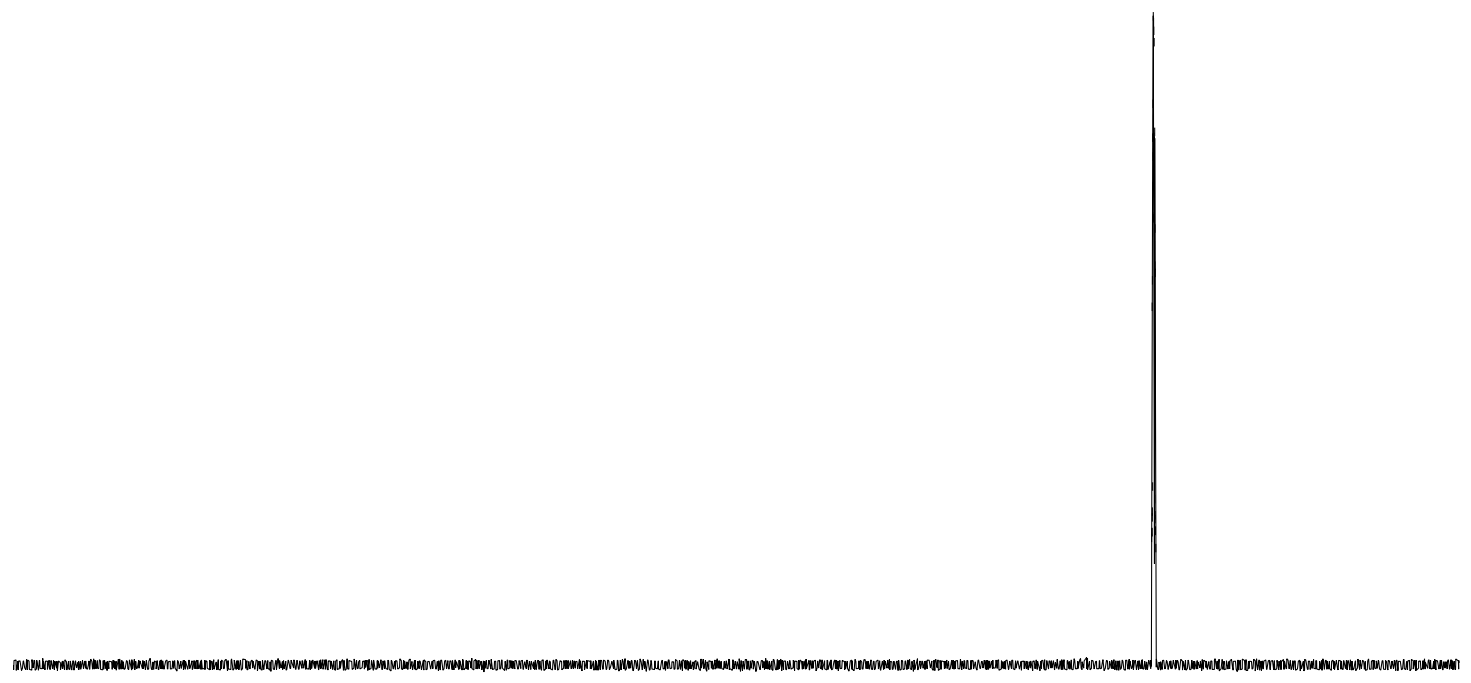

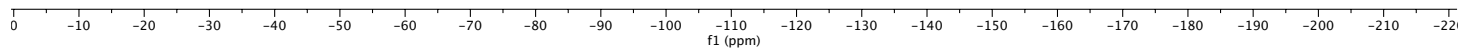


<smiles>CC(C)(F)CCOC(=O)c1ccc(Br)cc1</smiles>
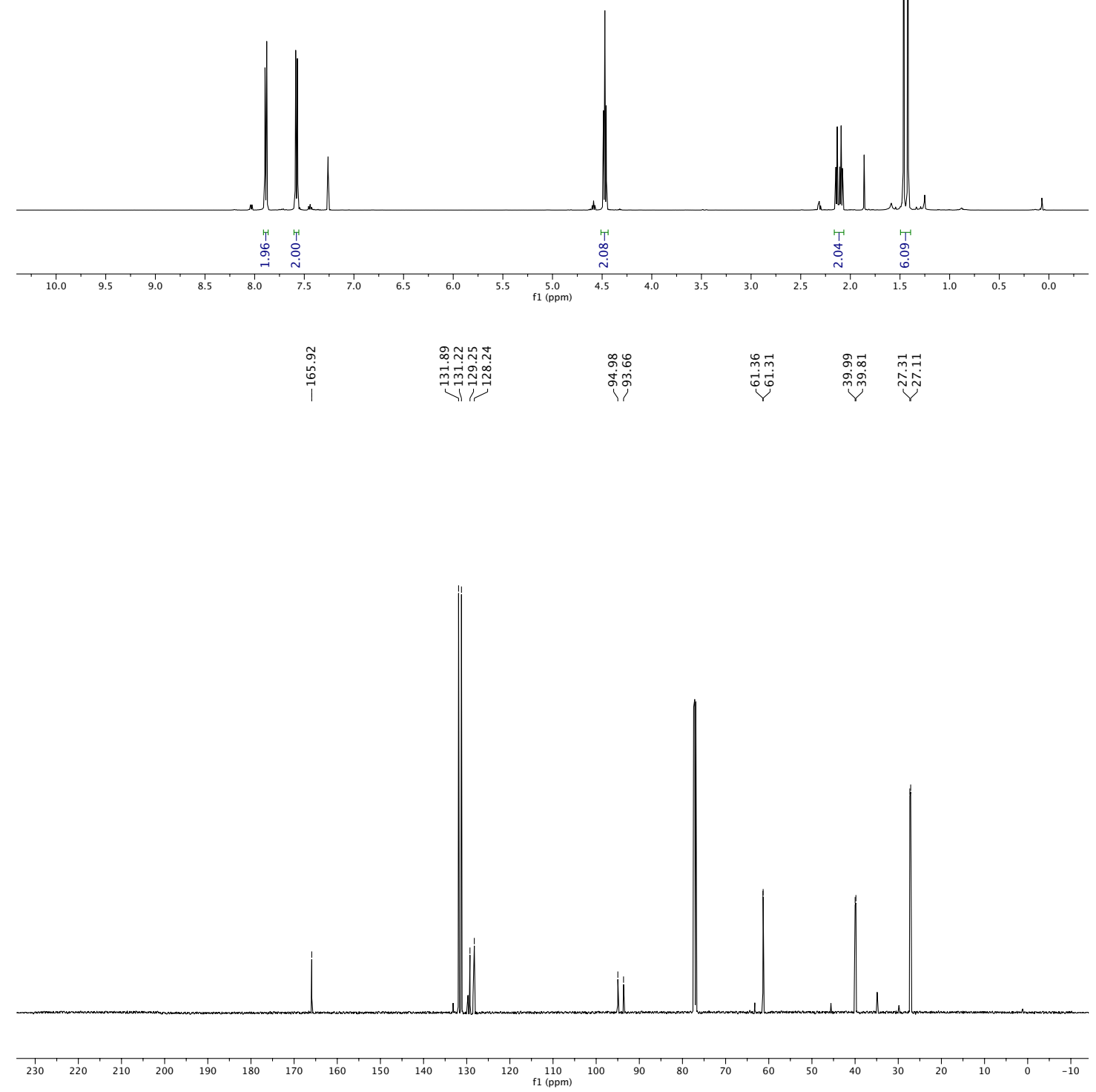


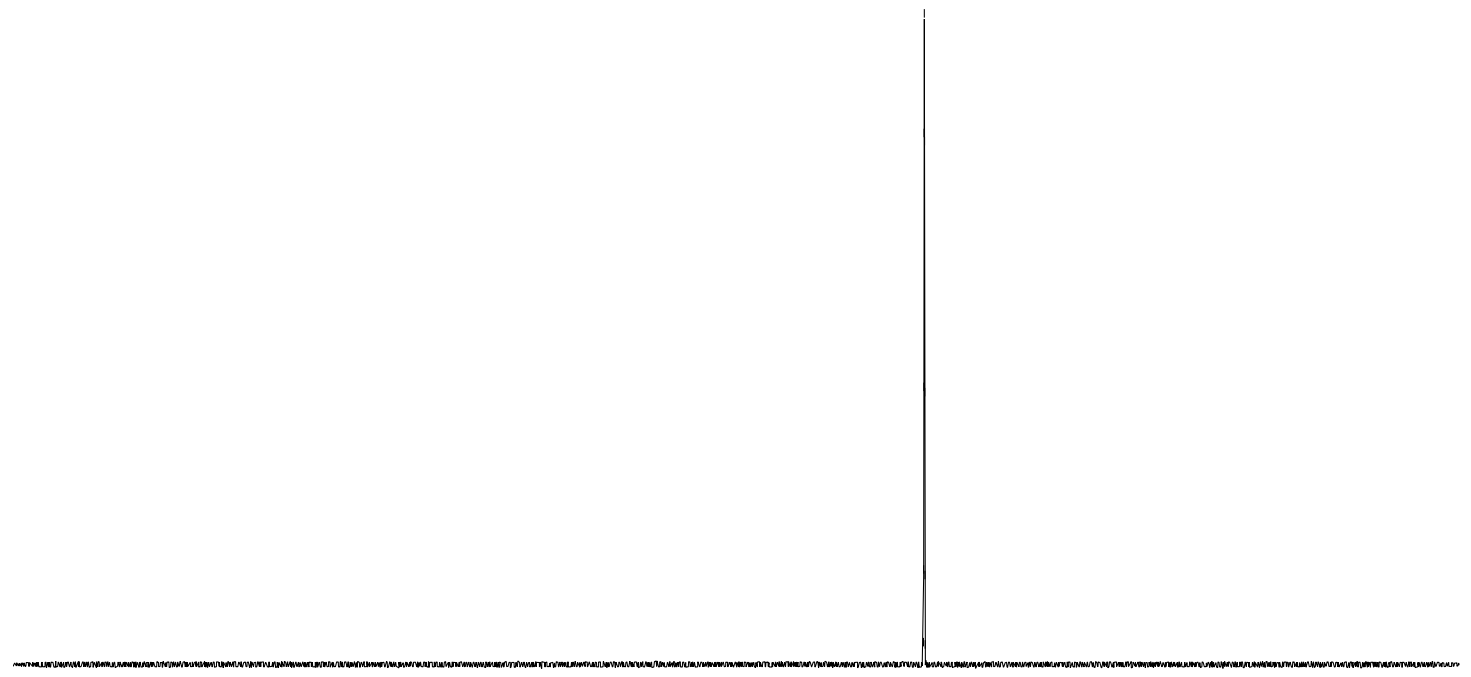

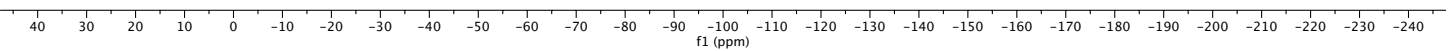
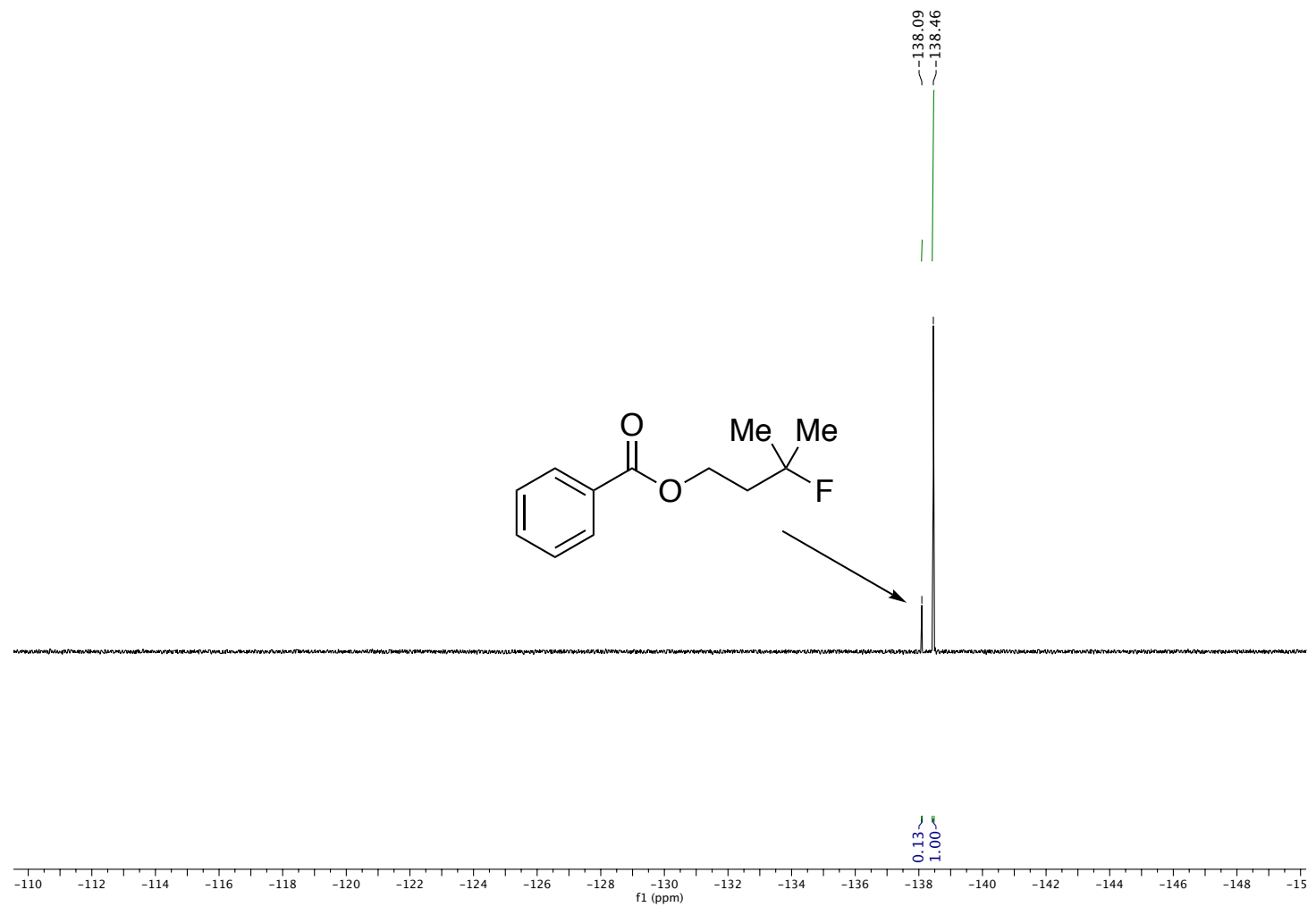

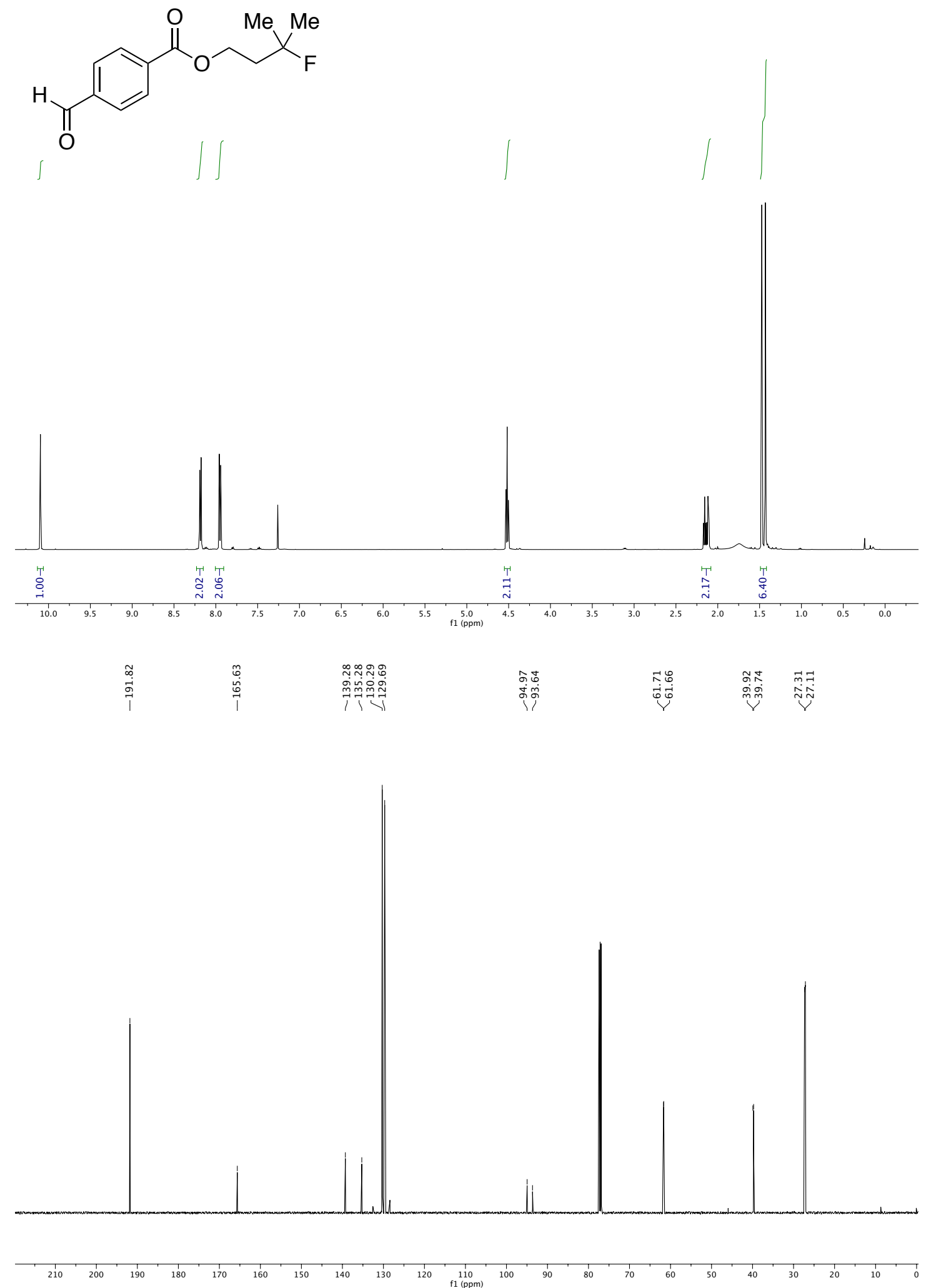


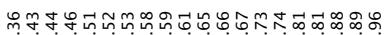

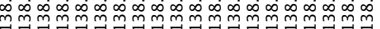

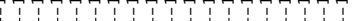

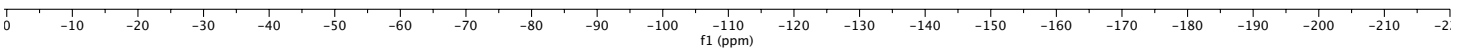



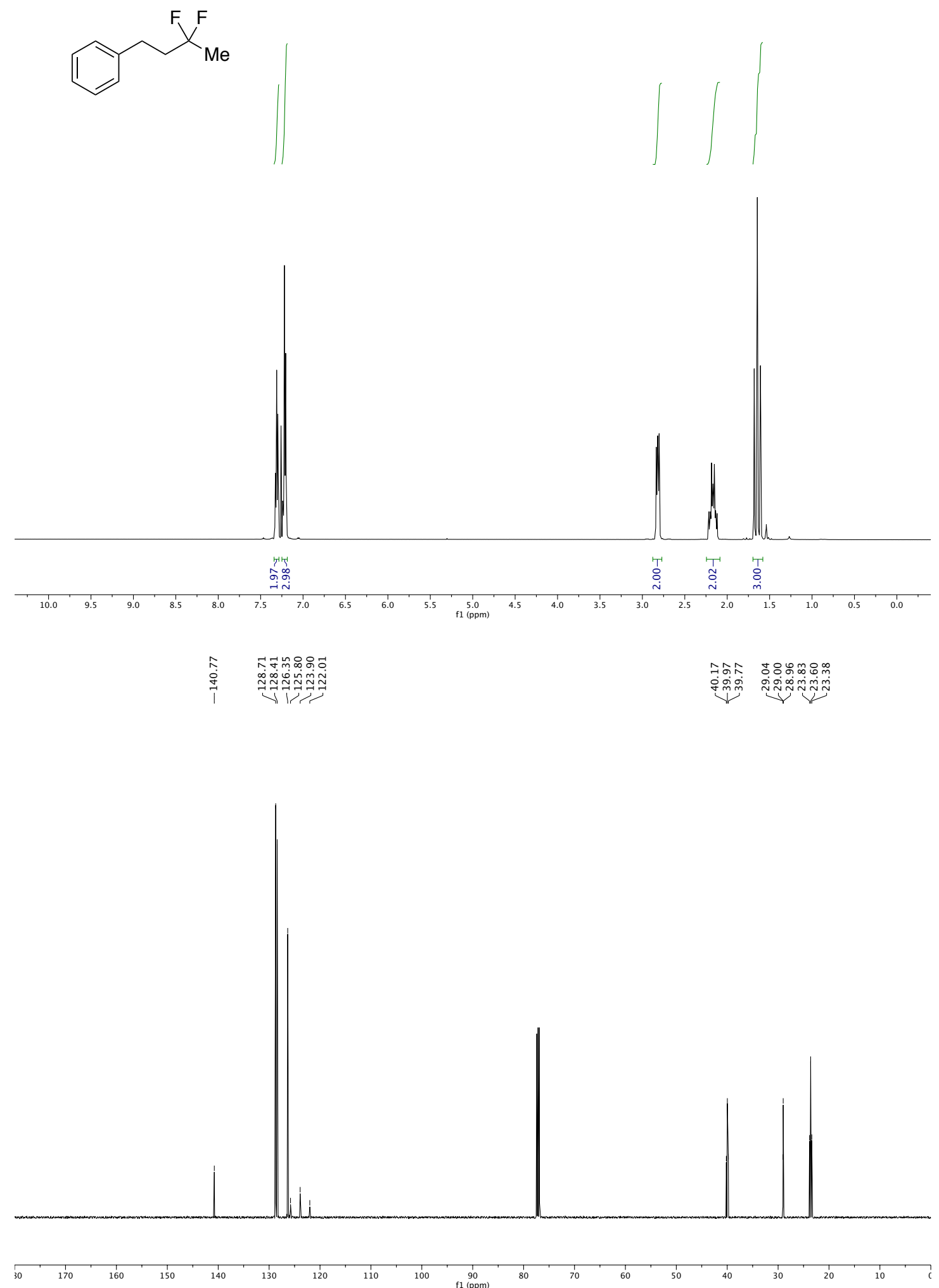


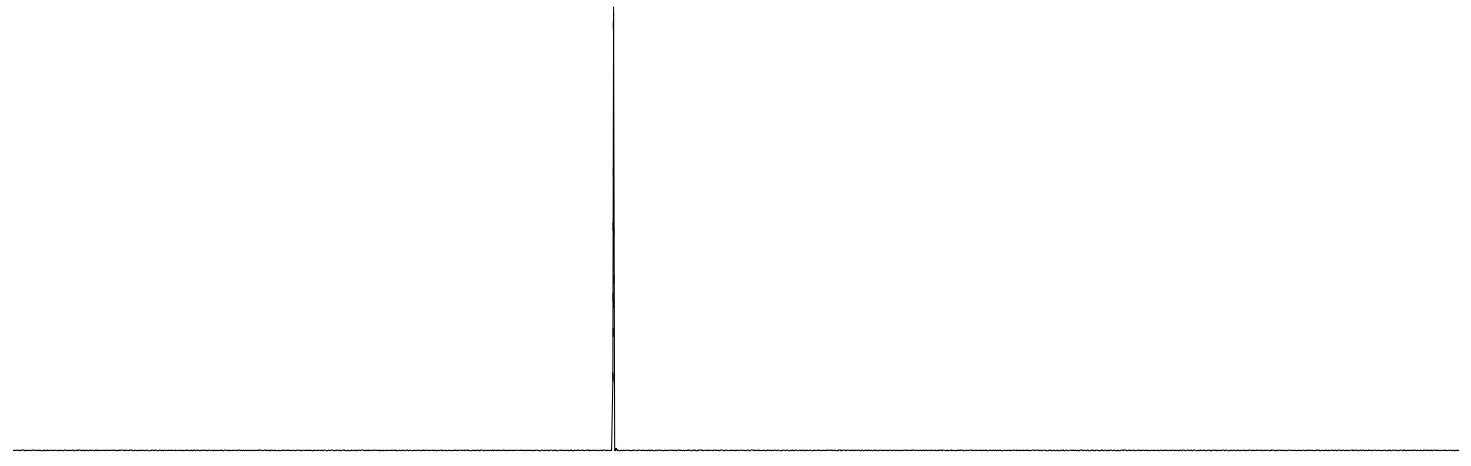

